SONIA MARIA MINELLI SENESE

\title{
STRESS E DESEMPENHO PROFISSIONAL EM TELEJORNALISMO
}

Dissertação apresentada ao Instituto de Psicologia da Universidade de São Paulo, como parte dos requisitos para obtenção do título de Mestre em Psicologia. 


\section{STRESS E DESEMPENHO PROFISSIONAL EM TELEJORNALISMO}

Dissertação apresentada ao Instituto de Psicologia da Universidade de São Paulo, como parte dos requisitos para obtenção do título de Mestre em Psicologia.

Área de concentração: Psicologia Social e do Trabalho

Orientador: Prof. Dr. Esdras Vasconcellos 

QUALQUER MEIO CONVENCIONAL OU ELETRÔNICO, PARA FINS DE ESTUDO E PESQUISA, DESDE QUE CITADA A FONTE.

Catalogação na publicação Serviço de Biblioteca e Documentação Instituto de Psicologia da Universidade de São Paulo

Senese, Sonia Maria Minelli.

Stress e desempenho profissional em telejornalismo / Sonia Maria Minelli Senese; orientador Esdras Guerreiro Vasconcellos. - São Paulo, 2008.

203 p.

Dissertação (Mestrado - Programa de Pós-Graduação em Psicologia. Área de Concentração: Psicologia Social e do Trabalho) - Instituto de Psicologia da Universidade de São Paulo.

1. Stress 2. Telejornalismo 3. Televisão 4. Jornalismo 5. Desempenho 6. Competência 7. Psicologia organizacional 8. Avaliação de desempenho I. Título. 
STRESS E DESEMPENHO PROFISSIONAL EM TELEJORNALISMO

SONIA MARIA MINELLI SENESE

\section{BANCA EXAMINADORA}

(Nome e Assinatura)

(Nome e Assinatura)

(Nome e Assinatura)

Aprovada em 
Ao Nico e Bruno Minhas preciosidades

Por estarem comigo nessa caminhada, estimulando-me sempre e reafirmando continuamente a confiança na minha capacidade de encarar esse desafio. 


\section{Agradecimentos sinceros:}

Primeiramente ao meu orientador Prof. Dr. Esdras Guerreiro Vasconcellos, pelos ensinamentos, sabedoria, paciência, apoio e pela maneira confiante e incentivadora com que me orientou durante todo o período de pós-graduação.

À minha família, meus pais Arturo e Teresa, meus irmãos Eduardo e Ricardo, e minha irmãzinha Silvana, pelo que vocês representam para mim.

À Prof. Dra. Maria Aparecida Coelho pelas contribuições valiosas, abertura e receptividade em todos os momentos.

Ao Prof. Dr. Sigmar Malvezzi pelas oportunidades de aprendizado, pela inteligência e por suas sugestões sempre muito oportunas que enriqueceram este trabalho.

À Heloisa Machado, por seu incentivo, compreensão e apoio em todos os momentos.

À querida Prof. Dra. Leny Kyrillos, por seu apoio incondicional, carinho e amizade.

À prof. Dra Valéria Paz de Almeida pela consultoria na área de língua portuguesa.

À prof. Yara Castro pela consultoria na área de estatística.

Aos colegas de equipe de pós-graduação, João, Fabio, Ester, Fátima e Elder, pela valiosa troca de informações e incentivo constantes.

Aos repórteres e repórteres cinematográficos que contribuíram com sua participação na pesquisa, por sua disponibilidade e coleguismo.

Aos telejornalistas, supervisores, gerentes, diretores e colegas da empresa pesquisada que me apoiaram e foram extremamente receptivos e colaboradores na realização desse estudo. 
Quem não sofreu essa servidão que se alimenta de imprevistos da vida, não pode imaginá-la. Quem não viveu a palpitação sobrenatural da notícia, o orgasmo do furo, a demolição moral do fracasso, não pode sequer conceber o que são. Ninguém que não tenha nascido para isso e esteja disposto a viver só para isso poderia persistir numa profissão tão incompreensível e voraz, cuja obra termina depois de cada notícia, como se fora para sempre, mas que não concebe um instante de paz enquanto não torna a começar com mais ardor do que nunca no minuto seguinte.

Gabriel Garcia Márquez

(trecho do discurso proferido na abertura da Conferência da Sociedad Interamericana de Prensa, em Los Angeles, EUA, 1996.) 


\section{SUMÁRIO}

I. APRESENTAÇÃ̃

II. INTRODUÇÃ

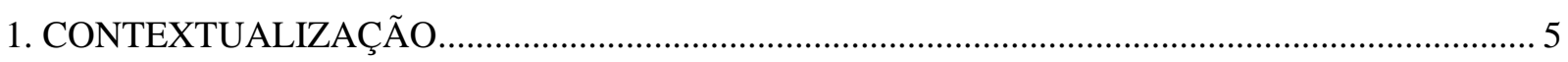

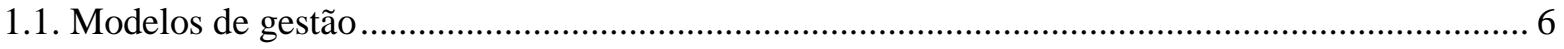

1.1.1. Paradigma tradicional - o modelo de gestão tayloriano e a relação stress $\mathrm{x}$ desempenho ........ 6

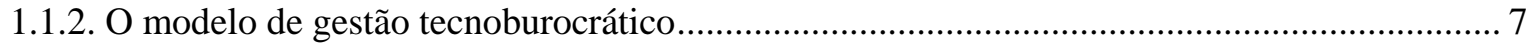

1.1.3. O modelo de gestão da excelência/eficácia e o modelo participativo...................................... 8

1.1.4. Cenário atual - o paradigma emergente de gestão de empresas, condições de trabalho e o

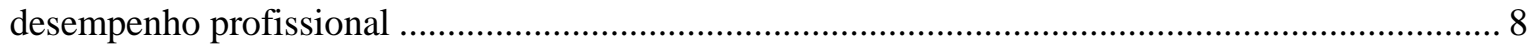

1.1.5. O paradigma emergente de gestão de empresas e o telejornalismo ..................................... 10

2. CULTURA ORGANIZACIONAL, CONFLITO DE GESTÃO E STRESS .................................... 11

III. FUNDAMENTAÇÃO TEÓRICA ...................................................................................................... 14

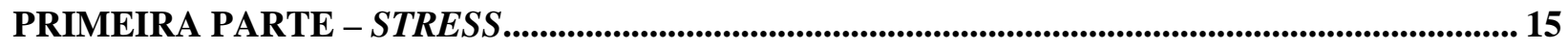

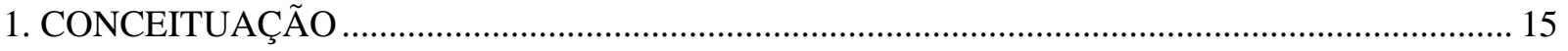

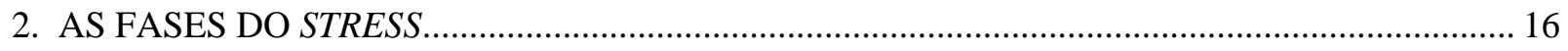

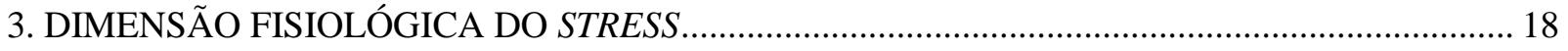

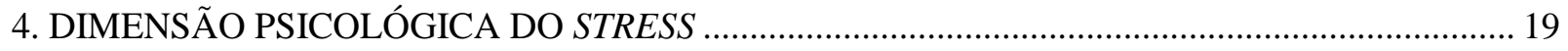

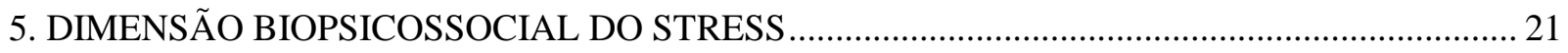

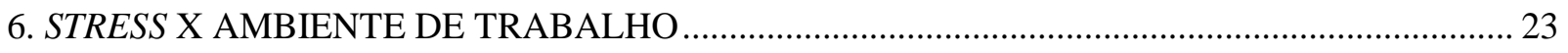

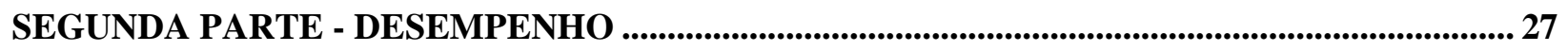

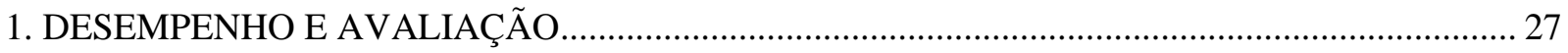

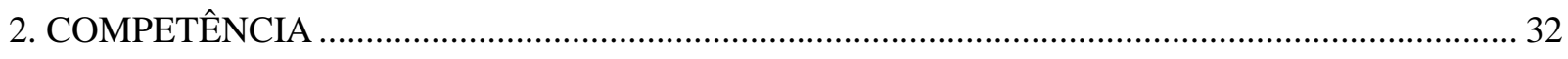

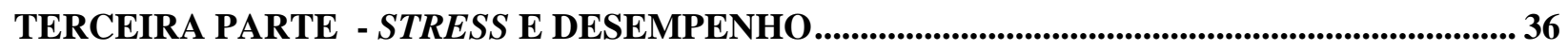

QUARTA PARTE - TELEJORNALISMO ............................................................................................ 40

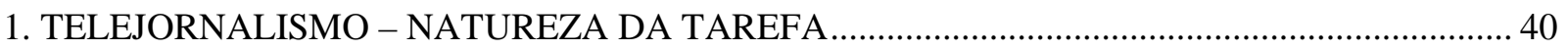

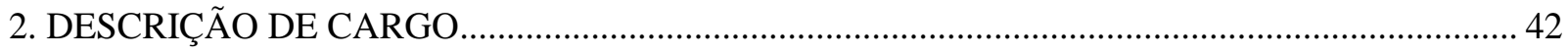

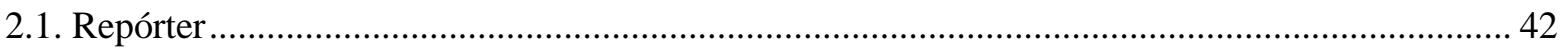




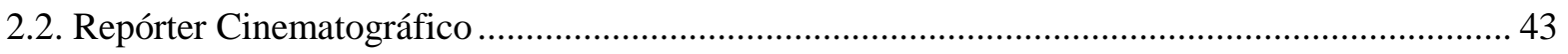

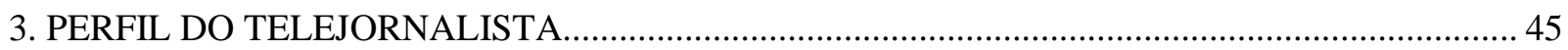

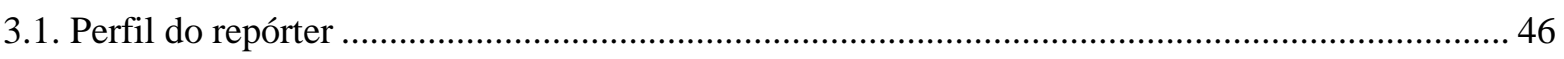

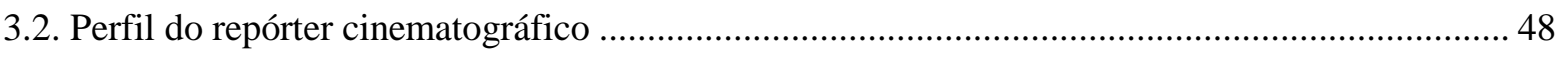

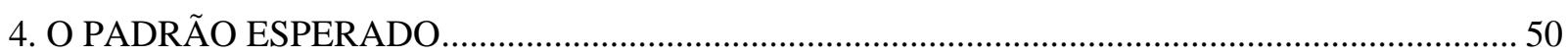

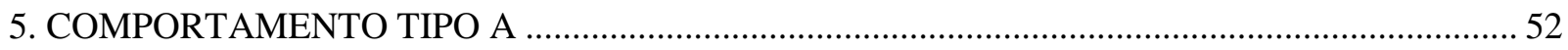

QUINTA PARTE - STRESS E DESEMPENHO NO TELEJORNALISMO................................... 54

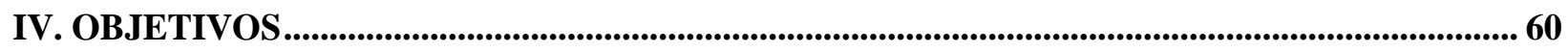

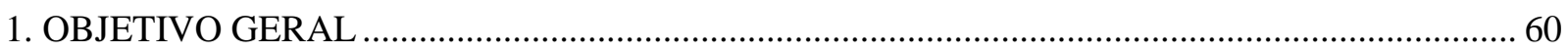

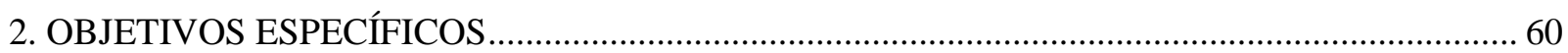

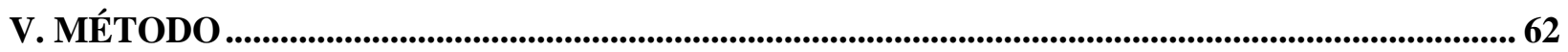

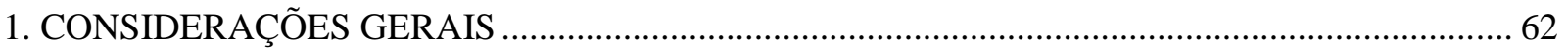

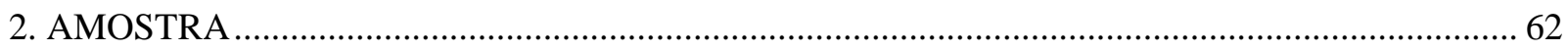

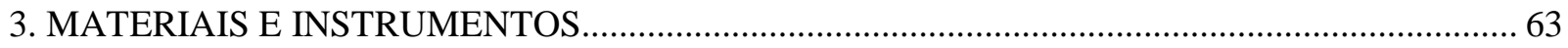

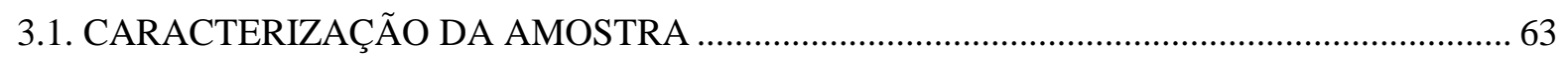

3.1.1. Formulário de caracterização da amostra (Anexo 1) ............................................................ 63

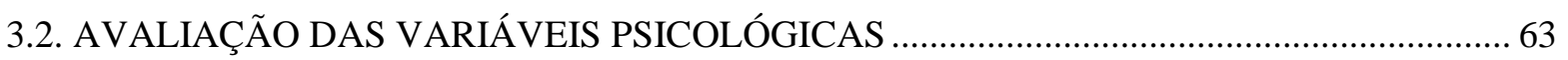

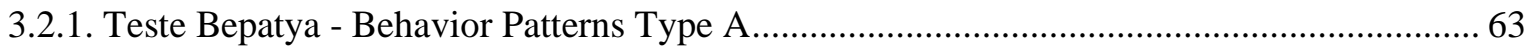

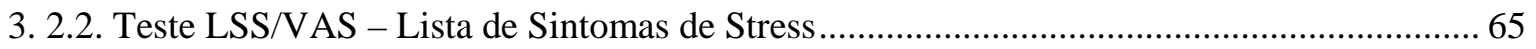

3.3. PLANILHA DE AVALIAÇÃO - COMPETÊNCIA E DESEMPENHO ..................................... 66

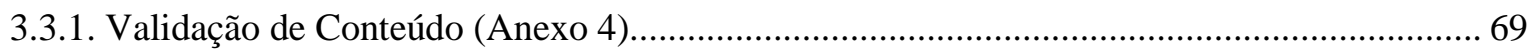

3.3.2. Perfil Padrão de Desempenho Definido pela Empresa (Anexos 5A e 5B) .......................... 70

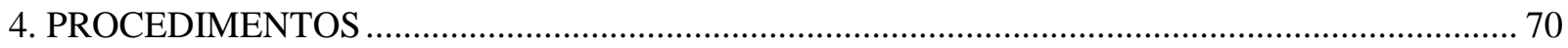

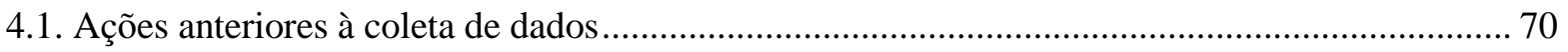

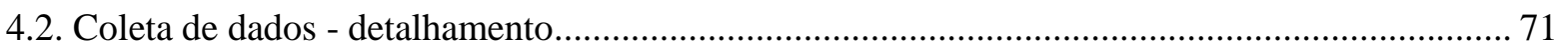

4.3. Gabaritos para a avaliação de competência e desempenho ......................................................... 72

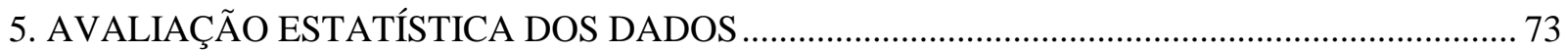

PARTE 1 - Resultados das variáveis sócio-demográficas ............................................................ 73

PARTE 2 - Resultados nos Instrumentos ................................................................................. 74

PARTE 3 - Matrizes de Intercorrelações ………...................................................................... 74

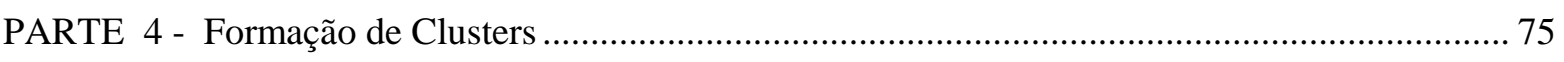

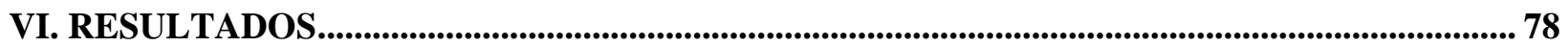


PARTE 1 - RESULTADOS DAS VARIÁVEIS SÓCIO-DEMOGRÁFICAS .................................... 78

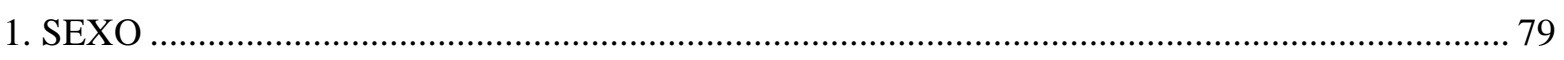

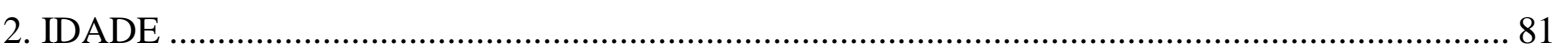

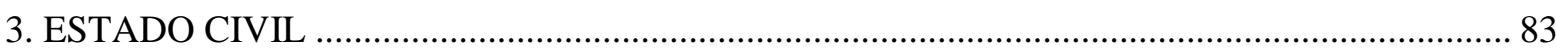

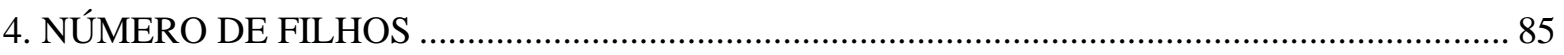

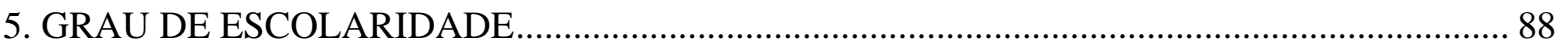

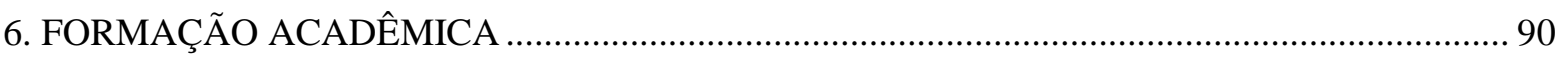

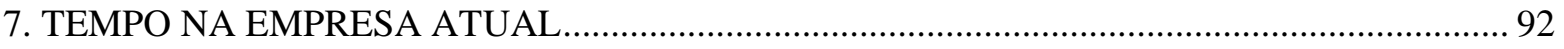

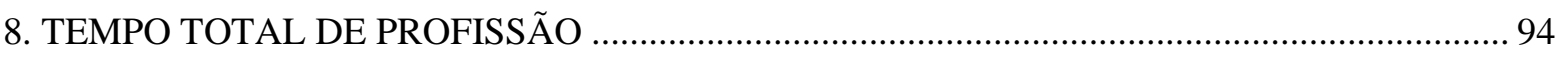

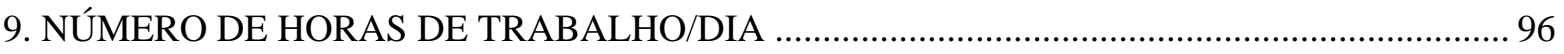

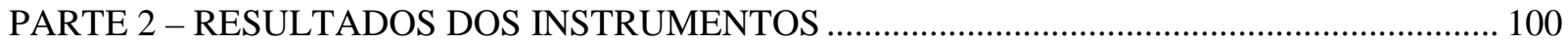

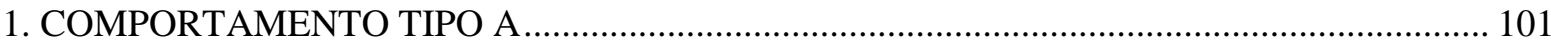

1.1. Análise dos resultados dos fatores específicos do BEPATYA ............................................. 102

2. LISTA DE SINTOMAS DE STRESS - LSS/VAS...................................................................... 111

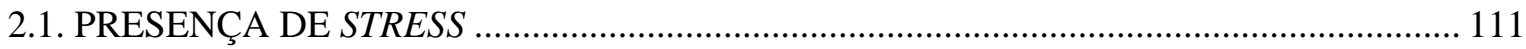

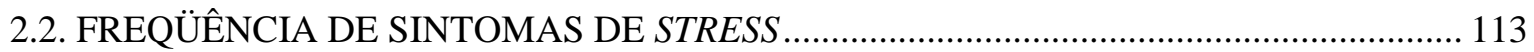

2.3. INTENSIDADE DE SINTOMAS DE STRESS ................................................................ 115

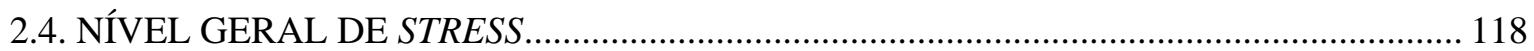

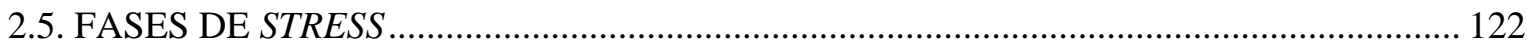

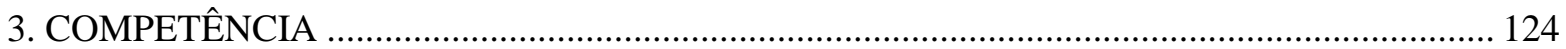

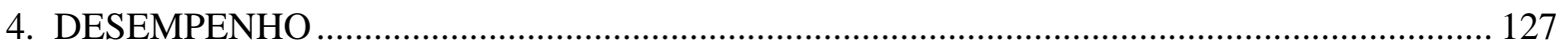

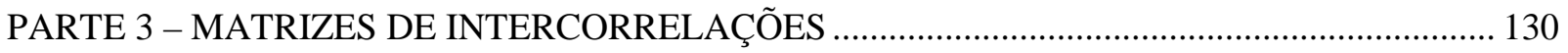

1- MATRIZ DE INTERCORRELAÇÃO - GRUPO R .............................................................. 131

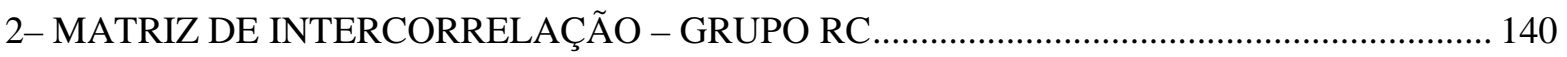

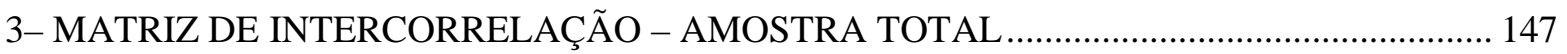

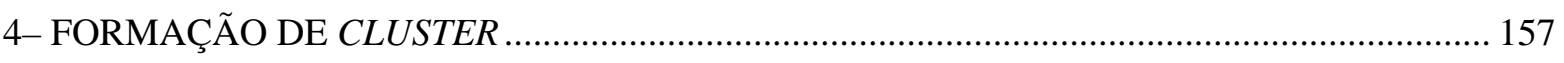

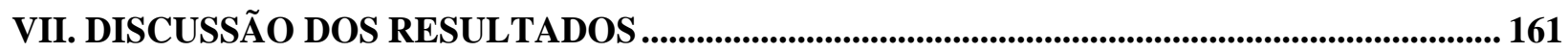

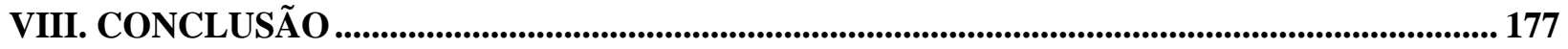

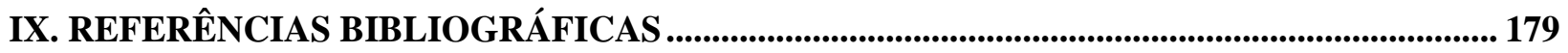

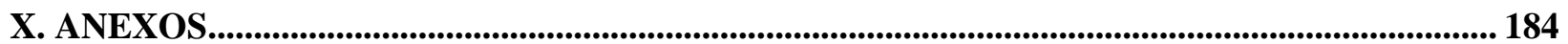

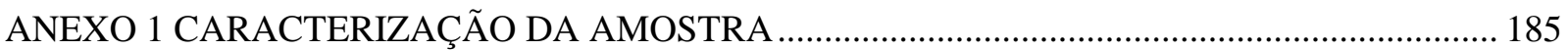

ANEXO 2- A DESCRIÇÃO DE CARGO - REPÓRTER .................................................................. 186 
ANEXO 2 - B DESCRIÇÃO DE CARGO - REPÓRTER CINEMATOGRÁFICO ........................... 188

ANEXO 3 A- PLANILHA DE AVALIAÇÃO - R .......................................................................... 190

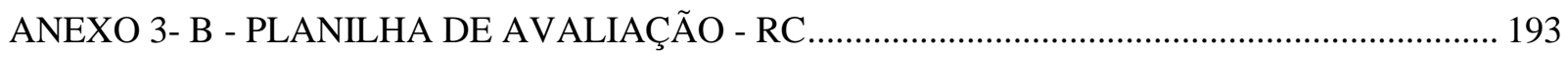

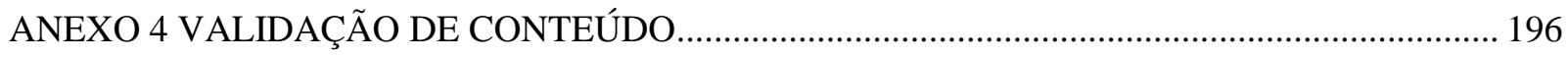

ANEXO 5-A DEFINIÇÃO DO PADRÃO DE DESEMPENHO DA EMPRESA - R ........................ 197

ANEXO 5-B DEFINIÇÃO DO PADRÃO DE DESEMPENHO DA EMPRESA - RC ...................... 198

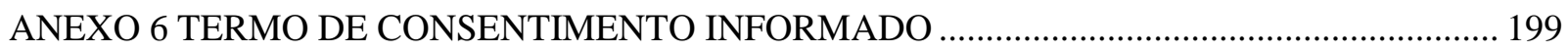

ANEXO 7 MATRIZ GERAL DE INTERCORRELAÇÃO DO GRUPO R ....................................... 201

ANEXO 9 MATRIZ GERAL DE INTERCORRELAÇÃO DO GRUPO RC .................................... 202

ANEXO 10 MATRIZ GERAL DE INTERCORRELAÇÃO DA AT ................................................ 203 


\section{LISTA DE FIGURAS}

Figura 1 e 2 . Distribuição de cargos por SEXO, para R e RC. ......................................................................... 79

Figura 3: Distribuição por SEXO nos Grupos e Amostra Total (1) ...................................................................... 80

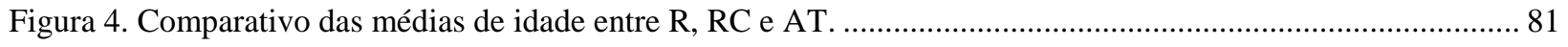

Figura 5. Distribuição dos sujeitos quanto à variável "estado civil", nos dois grupos e na amostra total.................... 83

Figura 6. Distribuição dos sujeitos quanto à variável "número de filhos", nos dois grupos e na amostra total. .......... 86

Figura 7. Gráfico "Error Bar" - Comparativo das médias e desvio padrão da variável "número de filhos"............. 86

Figura 8. Demonstrativo dos sujeitos quanto ao grau de escolaridade, nos dois grupos e na amostra total. .............. 89

Figura 9. Demonstrativo da distribuição da variável "formação acadêmica" nos dois grupos e na amostra total. ..... 90

Figura 10. Demonstrativo da distribuição das médias da variável "formação acadêmica" nos dois grupos e na amostra total.

Figura 11. Gráfico "Error Bar" - Comparativo das médias e desvio padrão da variável "tempo na empresa atual"

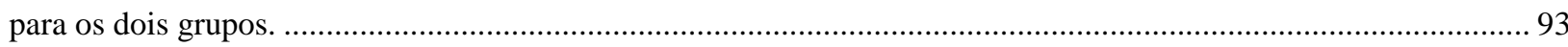

Figura 12. Distribuição das médias para a variável "tempo total de profissão" nos grupos e AT................................ 94

Figura 13. Distribuição do número de horas de trabalho/dia nos dois grupos............................................................ 97

Figura 14. Médias do número de horas de trabalho/dia nos dois grupos. .......................................................... 97

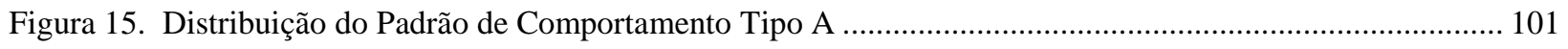

Figura 16. Distribuição do Padrão de Comportamento Tipo A - fator "senso de competência"............................. 103

Figura 17. Distribuição do Padrão de Comportamento Tipo A - fator "nervosismo". ............................................. 104

Figura 18. Distribuição do Padrão de Comportamento Tipo A - fator "nível de ambição". .................................... 105

Figura 19. Distribuição do Padrão de Comportamento Tipo A - fator "impaciência". ............................................ 106

Figura 20. Distribuição do Padrão de Comportamento Tipo A - fator "urgência de tempo"................................... 107

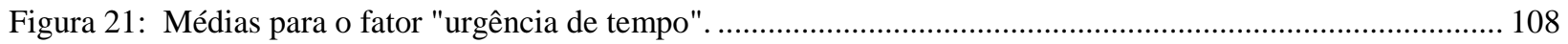

Figura 22. Distribuição do Padrão de Comportamento Tipo A - fator "incapacidade de desligar-se”..................... 109

Figura 23. Distribuição do Padrão de Comportamento Tipo A - fator "auto-sobrecarga". ...................................... 110

Figura 24. Distribuição da Presença de Sintomas de Stress................................................................................. 111

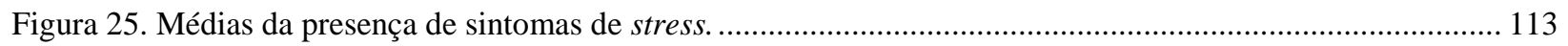

Figura 26. Médias de intensidade de sintomas de stress ....................................................................................... 115

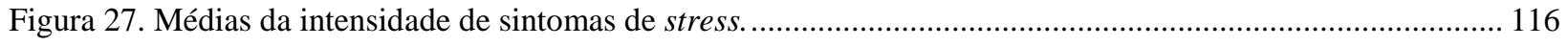

Figura 28. Distribuição dos resultados do nível geral de stress. ........................................................................... 118

Figura 29. Distribuição das fases de stress nos grupos R e RC e na AT, em \%....................................................... 122

Figura 30. Distribuição dos níveis de competências......................................................................................... 125

Figura 31. Distribuição dos níveis de desempenho....................................................................................... 127

Figura 32. Distribuição dos sujeitos em clusters, considerando a Amostra Total...................................................... 159 


\section{LISTA DE TABELAS}

Tabela 1: Distribuição dos sujeitos quanto à variável SEXO, considerando os grupos R e RC............................. 79

Tabela 2: Análise de significância da distribuição dos sujeitos quanto à variável "sexo", considerando a amostra total de R e RC.

Tabela 3: Média e desvio padrão para a variável "idade", considerando os grupos R e RC e AT. 81

Tabela 4: Análise de significância da distribuição dos sujeitos quanto à variável "idade", considerando a amostra total de R e RC.

Tabela 5: Distribuição dos sujeitos conforme o "estado civil", considerando os grupos R e RC e amostra total....... 83

Tabela 6: Análise de significância da distribuição dos sujeitos quanto à variável "estado civil", considerando a amostra total de R e RC.

Tabela 7: Média e desvio padrão obtidos quanto à variável "número de filhos", considerando os grupos R e RC e a amostra total.

Tabela 8. Demonstrativo dos sujeitos quanto à variável "número de filhos", nos dois grupos e na amostra total.... 85 Tabela 9: Análise de significância da distribuição dos sujeitos quanto à variável "número de filhos", considerando a

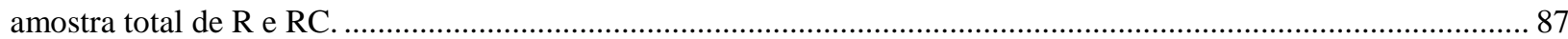

Tabela 10: Distribuição da variável "grau de escolaridade", considerando os grupos R e RC e a amostra total....... 88 Tabela 11: Análise de significância da distribuição dos sujeitos quanto à variável "grau de escolaridade", considerando a amostra total de R e RC.

Tabela 12. Distribuição dos grupos R, RC e AT quanto à variável "formação acadêmica". ...................................... 90

Tabela 13. Análise de significância da AT para a variável "formação acadêmica"..................................................91

Tabela 14: Média e desvio padrão obtidos para a variável "tempo na empresa atual", considerando os grupos R e RC e a amostra total.

Tabela 15: Análise de significância da distribuição dos sujeitos quanto à variável "tempo na empresa atual", considerando a amostra total de R e RC.

Tabela 16: Média e desvio padrão obtidos para a variável "tempo total de profissão", considerando os grupos R e RC e a amostra total.

Tabela 17: Análise de significância da distribuição dos sujeitos quanto à variável "tempo total de profissão", considerando a amostra total de R e RC.

Tabela 18: Média e desvio padrão obtidos para a variável "número de horas de trabalho/dia", considerando os grupos R e RC e a amostra total.

Tabela 19. Distribuição dos sujeitos quanto à variável "número de horas de trabalho/dia" nos dois grupos. .96

Tabela 20: Análise de significância da distribuição dos sujeitos quanto à variável "número de horas de trabalho/dia", considerando a amostra total de R e RC.

Tabela 21: Distribuição da variável "comportamento tipo A" nos grupos R e RC e na amostra total (em \%). 101

Tabela 22: Distribuição da variável "comportamento tipo A", considerando os grupos R e RC separadamente e a amostra total (médias e desvio padrão). 
Tabela 23: Análise de significância para a variável "comportamento tipo A", considerando a amostra total de R e RC. 102

Tabela 24: Média e desvio padrão obtidos para o fator "senso de competência". .............................................. 103

Tabela 25: Análise de significância para o fator "senso de competência" na amostra total................................ 103

Tabela 26: Média e desvio padrão obtidos para o fator "nervosismo", considerando os grupos R e RC................ 104

Tabela 27: Análise de significância para o fator "nervosismo" na amostra total. ................................................ 104

Tabela 28: Média e desvio padrão obtidos para o fator "nível de ambição", considerando os grupos R e RC......... 105

Tabela 29: Análise de significância para o fator "nível de ambição" na amostra total. ...................................... 105

Tabela 30: Média e desvio padrão obtidos para o fator "impaciência".......................................................... 106

Tabela 31: Análise de significância para o fator "impaciência" na amostra total. ............................................. 106

Tabela 32: Média e desvio padrão obtidos para o fator "urgência de tempo"................................................... 107

Tabela 33: Análise de significância para o fator "urgência de tempo". ......................................................... 108

Tabela 34: Média e desvio padrão obtidos para o fator "incapacidade de desligar-se". ..................................... 109

Tabela 35: Análise de significância para o fator "incapacidade de desligar-se" na amostra total......................... 109

Tabela 36: Média e desvio padrão obtidos para o fator "auto-sobrecarga"...................................................... 110

Tabela 37: Análise de significância para o fator "auto-sobrecarga" na amostra total....................................... 110

Tabela 38: Distribuição dos resultados em \% da variável "presença de sintomas de stress", considerando os grupos $\mathrm{R}$ e RC separadamente e a amostra total.

Tabela 39: Distribuição das médias, desvio padrão e nível da variável "presença de sintomas de stress", considerando os grupos R e RC separadamente e a amostra total.

Tabela 40: Análise de significância para a variável "presença de sintomas de stress", considerando a amostra total de $\mathrm{R}$ e RC.

Tabela 41: Distribuição dos resultados em \% da variável "freqüência de sintomas de stress", considerando os grupos $\mathrm{R}$ e RC separadamente e a amostra total.

Tabela 42: Distribuição das médias, desvio padrão e nível da variável "frequiência de sintoma de stress", considerando os grupos R e RC separadamente e a amostra total.

Tabela 43: Análise de significância para a variável "freqüência de sintomas de stress", considerando a amostra total de R e RC.

Tabela 44: Distribuição dos resultados em \% da variável "intensidade de sintomas de stress", considerando os grupos R e RC separadamente e a amostra total.

Tabela 45: Distribuição das médias, desvio padrão e nível da variável "intensidade de sintomas de stress", considerando os grupos R e RC separadamente e a amostra total.

Tabela 46: Análise de significância para a variável "intensidade de sintomas de stress", considerando a amostra total de $\mathrm{R}$ e RC

Tabela 47: Distribuição do nível geral de stress nos grupos R e RC separadamente e na amostra total. 118

Tabela 48: Análise de significância para o nível geral de stress, considerando a amostra total de R e RC. 119

Tabela 49: Ranking dos itens de sintomas mais representativos no grupo R. 119

Tabela 50: Ranking dos itens de sintomas mais representativos no grupo RC. 
Tabela 51. Distribuição dos sintomas de stress no grupo R e RC (\%). 120

Tabela 52 Relação das respostas de sintomas de stress que apareceram nos dois grupos. 121

Tabela 53: Distribuição das fases de stress nos grupos R e RC separadamente e na amostra total........................ 122

Tabela 54: Análise de significância para as fases de stress, considerando a amostra total de R e RC.................. 123

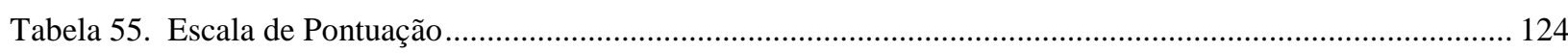

Tabela 56: Distribuição do nível de competência (\%) nos grupos R e RC separadamente e na amostra total. 124

Tabela 57: Distribuição das médias e desvio padrão da variável "nível de competência" nos grupos R e RC

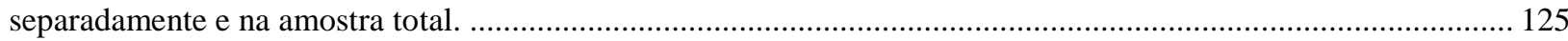

Tabela 58: Análise de significância para o nível de competência, considerando a amostra total de R e RC........... 126

Tabela 59: Distribuição do nível de desempenho nos grupos R e RC e na amostra total. 127

Tabela 60: Distribuição das médias e desvio padrão da variável "desempenho" nos grupos R e RC separadamente e

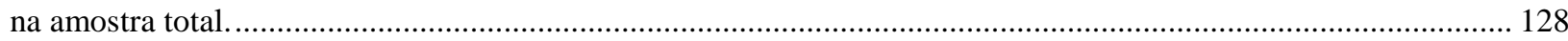

Tabela 61: Análise de significância para o nível de desempenho, considerando a amostra total de R e RC........... 128

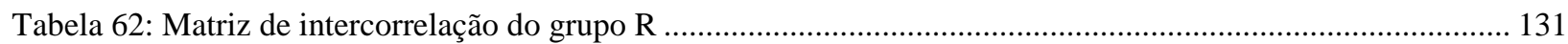

Tabela 63: Distribuição da correlação entre sexo e idade no grupo R .......................................................... 132

Tabela 64: Distribuição da correlação entre sexo e desempenho no grupo R................................................ 132

Tabela 65: Distribuição da correlação entre idade e número de filhos no grupo R (em \%) ................................... 133

Tabela 66: Distribuição da correlação entre idade e tempo de empresa no grupo R (em \%) ................................. 133

Tabela 67: Distribuição da correlação entre idade e tempo de empresa no grupo R (em \%) ................................ 133

Tabela 68: Distribuição da correlação entre idade e competência no grupo R (em \%) ....................................... 134

Tabela 69: Distribuição da correlação entre idade e desempenho no grupo R (em \%)....................................... 134

Tabela 70: Distribuição da correlação entre estado civil e número de filhos no grupo R (em \%) ......................... 134

Tabela 71: Distribuição da correlação entre número de filhos e tempo de profissão no grupo R (em \%) ............... 135

Tabela 72: Distribuição da correlação entre número de filhos e tempo de profissão no grupo R (em \%) ............... 135

Tabela 73: Distribuição da correlação entre número de filhos e competência no grupo R (em \%) ....................... 135

Tabela 74: Distribuição da correlação entre número de filhos e desempenho no grupo R (em \%) ........................ 136

Tabela 75: Distribuição da correlação entre tempo de empresa e competência no grupo R (em \%) ...................... 136

Tabela 76: Distribuição da correlação entre tempo de empresa e desempenho no grupo R (em \%) ...................... 136

Tabela 77: Distribuição da correlação entre tempo de profissão e competência no grupo R (em \%) ..................... 137

Tabela 78: Distribuição da correlação entre tempo de profissão e desempenho no grupo R (em \%) ..................... 137

Tabela 79: Correlação entre presença e freqüência de sintomas de stress no grupo R (em \%)............................. 138

Tabela 80: Correlação entre freqüência e intensidade de sintomas de stress no grupo R (em \%) ......................... 138

Tabela 81: Correlação entre freqüência de sintomas de stress e comportamento tipo A no grupo R (em \%).......... 138

Tabela 82: Distribuição da correlação entre competência e desempenho no grupo R (em \%) ............................... 139

Tabela 83: Matriz de intercorrelação do grupo RC ....................................................................................... 140

Tabela 84: Distribuição da correlação entre idade e número de filhos no grupo RC (em \%) ................................ 141

Tabela 85: Correlação entre idade e tempo de empresa no grupo RC (em \%) ............................................... 141

Tabela 86: Correlação entre idade e tempo de profissão no grupo RC (em \%) .............................................. 142 
Tabela 87: Correlação entre idade e n. de horas no grupo RC (em \%)

Tabela 88: Correlação entre estado civil e número de filhos no grupo RC (em \%) 142

Tabela 89: Correlação entre número de filhos e tempo de empresa no grupo RC (em \%)...... 143

Tabela 90: Correlação entre escolaridade e n.horas no grupo RC (em \%) ........................................................ 143

Tabela 91: Correlação entre tempo de empresa e de profissão no grupo RC (em \%) ......................................... 143

Tabela 92: Correlação entre tempo de empresa e presença de sintomas de stress no grupo RC (em \%)................ 144

Tabela 93: Correlação entre tempo de empresa e comportamento tipo A no grupo RC (em \%) ........................... 144

Tabela 94: Correlação entre n. horas e comportamento tipo A no grupo RC (em \%) ....................................144

Tabela 95: Correlação entre presença e freqüência de sintomas de stress no grupo RC (em \%) ........................... 145

Tabela 96: Correlação entre presença e intensidade de sintomas de stress no grupo RC (em \%)......................... 145

Tabela 97: Correlação entre freqüência e intensidade de sintomas de stress no grupo RC (em \%) ....................... 145

Tabela 98: Distribuição da correlação entre competência e desempenho no grupo RC (em \%)........................... 146

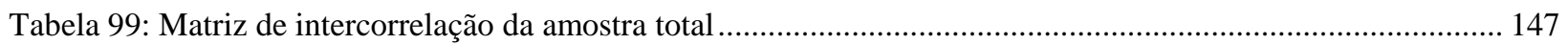

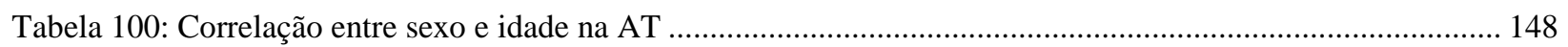

Tabela 101: Distribuição da correlação entre sexo e n. filhos na AT ............................................................ 148

Tabela 102: Correlação entre sexo e tempo de profissão na AT (em \%) ...................................................... 148

Tabela 103: Correlação entre sexo e intensidade de sintomas de stress na AT (em \%) ...................................... 149

Tabela 104: Distribuição dos sujeitos conforme a correlação entre sexo e nível de desempenho ........................... 149

Tabela 105. Distribuição da correlação entre idade e estado civil na AT ...................................................... 149

Tabela 106: Distribuição da correlação entre idade e número de filhos na AT ............................................... 150

Tabela 107: Correlação entre idade e tempo de empresa na AT (em \%) ........................................................ 150

Tabela 108: Correlação entre idade e tempo de profissão na AT (em \%) ........................................................ 151

Tabela 109: Distribuição da correlação entre estado civil e número de filhos na AT (em \%) ............................. 151

Tabela 110: Distribuição da correlação entre número de filhos e tempo de empresa na AT (em \%) ...................... 151

Tabela 111: Distribuição da correlação entre número de filhos e tempo de profissão na AT (em \%) ..................... 152

Tabela 112: Distribuição da correlação entre número de filhos e desempenho na AT (em \%) ............................. 152

Tabela 113: Distribuição da correlação entre escolaridade e tempo de empresa na AT (em \%) ............................ 152

Tabela 114: Distribuição da correlação entre tempo de empresa e tempo de profissão na AT (em \%) .................. 153

Tabela 115: Correlação entre tempo de empresa e N. hs /dia na AT (em \%) ............................................. 153

Tabela 116: Correlação entre tempo de empresa e comportamento tipo A na AT (em \%).................................... 154

Tabela 117: Distribuição da correlação entre tempo de profissão e desempenho na AT (em \%) .......................... 154

Tabela 118: Correlação entre presença e freqüência de sintomas de stress na AT (em \%) .................................. 154

Tabela 119: Correlação entre presença e intensidade de sintomas de stress na AT (em \%) ................................ 155

Tabela 120: Correlação entre freqüência de sintomas de stress e comportamento tipo A na AT (em \%) ............... 155

Tabela 121: Correlação entre freqüência e intensidade de sintomas de stress na AT (em \%) ................................ 155

Tabela 122: Distribuição da correlação entre competência e desempenho na AT (em \%) ................................... 156 


\section{SENESE, Sonia Maria Minelli - Stress e Desempenho Profissional em Telejornalismo. São Paulo, 2008, 203p. - Dissertação (Mestrado) Instituto de Psicologia da USP}

\section{RESUMO}

A presente pesquisa teve como objetivo estudar o nível de stress em telejornalistas, especificamente em repórteres e repórteres cinematográficos, e conhecer o grau de relação com o nível de desempenho profissional. Pretendeu-se comparar também o stress com o nível de habilidades/competências técnicas, bem como com o padrão de bom desempenho definido pela empresa e o padrão de comportamento Tipo A. Estruturaram-se três matrizes de intercorrelações demonstrando o cruzamento entre todas as variáveis da pesquisa. A amostra foi composta por 40 sujeitos: 20 repórteres $(\mathrm{R})$ e 20 repórteres cinematográficos (RC), funcionários de uma mesma empresa de comunicação, localizada em São Paulo. Foi aplicado o teste LSS/VAS (lista de sintomas de stress), o teste Bepatya (comportamento Tipo A), e o instrumento de avaliação de desempenho e competência. A avaliação de desempenho compreendeu a autoavaliação do sujeito e a avaliação de duas chefias imediatas, de forma consensual. Os resultados indicaram elevada presença de sintomas de stress, nível geral de stress médio-alto, nível de freqüência médio, sinais de stress da fase de perigo agudo e elevado padrão de comportamento Tipo A. A intensidade de stress resultou em nível médio e maior no grupo R do que no grupo RC. Os resultados dos níveis de desempenho e competência concentraram-se no nível dois, ou seja, os sujeitos desempenhamse plenamente dentro do padrão definido pela emissora para os cargos pesquisados. A pesquisa demonstrou que os resultados de stress foram evidenciados em todos os níveis de desempenho dos telejornalistas e não está correlacionado diretamente a um resultado específico. A resposta dos sujeitos ao stress relaciona-se à percepção individual, capacidade de coping, personalidade, padrão de comportamento Tipo A (fatores endógenos) e fatores relacionados ao ambiente, gestão organizacional e natureza da tarefa (fatores exógenos). 
SENESE, Sonia Maria Minelli - Stress and Profissional Performance in Journalism Television. São Paulo, 2008, 203p. - Dissertation (Mestrado) - University of São Paulo (USP) Psychology Institute

\begin{abstract}
The main purpose of this research was to study the stress level in journalists working on television, specially reporters and cameramen, and know the relationship level with the professional performance. The aim was also to compare the stress related to the abilities and technical competences, as well as, the good performance patterns defined by the company and the Behavior Pattern Level A. It was structured three correlation matrix showing the crossing between all the the research variables data. The sample was formed by 40 professionals: 20 reporters and 20 cameramen, all working at the same television company, located in São Paulo. It was applied the LSS/VAS test (stress symptom list), the Bepatya Test (A Type Behavior) and the professional performance and the technical capabilities instruments. The professional performance resulted by the employee self evaluation and the evaluation of managers in a consensual form. The results indicated high presence of stress symptom, medium-high stress general level, medium stress frequency, evidences of acute danger stress state and elevated Behavior Pattern Type A. The stress intensity level was medium and more intense among reporters than cameramen group. The results of performance level and competence were concentrated in level 2 , and it means that, the subjects perform according to the company defined pattern for the job. The research showed stress evidences in all levels of performance in journalists working on television and no significant correlation was found between stress and professional performance. The answer to the stress is related to individual perception, coping capability, personality, behavior pattern type A, environmental factors, organizational management and job characteristics.
\end{abstract}




\section{APRESENTAÇÃO}


O interesse em realizar uma pesquisa científica sobre o stress (1) e o desempenho no meio telejornalístico foi despertado pela possibilidade de investigar e ampliar a percepção do comportamento do jornalista, categoria profissional em grande evidência e considerada a quinta profissão mais estressante segundo pesquisa realizada pela ISMA-BRASIL (International Stress Management Association) em 2003, e a sétima segundo a classificação do Center for Disease Control dos EUA, em 2005. Stress e desempenho profissional são temáticas atuais diretamente relacionadas à dinâmica organizacional e à postura de enfrentamento do indivíduo em situações de trabalho.

O ambiente no qual o telejornalista atua, a redação, é um local em que os profissionais monitoram permanentemente as informações do país e do mundo. É um ambiente permeado por agentes stressores (2) em potencial, como a pressão pela agilidade da notícia e o elevado nível de exigência na precisão dos fatos. Também se caracteriza por ser um espaço estimulador e motivador pela própria natureza da atividade jornalística, que "transpira" informação e atualidade, forma opinião e possibilita satisfação e desafios enormes para os profissionais que nele atuam. Ter competência e bom desempenho profissional é condição extremamente necessária para que a cobertura dos acontecimentos diários seja feita com propriedade.

Em telejornalismo há diversas funções e podemos dividi-las em três grupos: no primeiro grupo, encontram-se os profissionais que "emprestam" sua imagem ao vídeo e que, portanto, estão mais expostos à mídia (os repórteres e apresentadores); no segundo grupo, estão os que trabalham nos bastidores da redação, à frente do computador ou ao telefone, na corrida atrás das fontes, na busca da confirmação da informação para entregar a matéria dentro do prazo do fechamento (os produtores e editores); no terceiro, os profissionais que vão a campo, dedicam-se à captação da imagem que, por si só, é a notícia em televisão (os repórteres cinematográficos). Nesse universo de pessoas, há jornalistas que atuam em telejornais transmitidos em rede nacional e os que cuidam da preparação de telejornais regionais, de abrangência local.

A atuação profissional em jornalismo televisivo requer objetividade na tomada de decisão e ritmo ágil, para que haja resposta à imprevisibilidade dos fatos e as notícias em tempo real sejam mostradas em primeira mão. Analisar de forma aprofundada o nível de stress dos 
telejornalistas e como se desempenham num contexto extremamente dinâmico é algo que ratifica a importância de estudos da Psicologia Social nessa área.

O estudo a ser apresentado, busca destacar duas funções essenciais no telejornalismo, as de "repórter" e "repórter cinematográfico", porque são complementares e porque suas habilidades e competências, não apenas técnicas, são muito exigidas no dia-a-dia e interferem no desempenho individual e impactam o produto final que vai ao ar. $\mathrm{O}$ jornalista cria um mundo que, para a maioria das pessoas, é tido como verdadeiro. Ele modela a realidade e qualquer incorreção na comunicação pode facilmente levar a repercussões desastrosas, pelo alcance que a notícia da televisão tem.

O repórter cinematográfico é o profissional que capta as imagens e está atento a todos os estímulos externos. O olho dele é a câmera. O repórter é o que está sempre informado e preparado para reportar os fatos importantes à sociedade. Ambas as funções permitem que se vivencie ativamente a imprevisibilidade e tal característica é a que define fundamentalmente o perfil profissional, sobretudo no telejornalismo diário. Deparam-se cotidianamente com o enfrentamento de obstáculos e de situações adversas ao exercício profissional, mas também com o prazer em ver a imagem bem captada, a matéria no ar e a possibilidade de, ao levar a notícia, ter o sentimento de compromisso cumprido com a comunidade.

Ao fazer uma revisão da literatura, deparamos com a carência de estudos que apontem para uma estruturação metodológica do stress e que ampliem a compreensão da atuação do jornalista no contexto organizacional. Heloani (2003) confirmou essa dificuldade em sua pesquisa com jornalistas, quando se referiu à falta de estudos sistematizados sobre a atividade do jornalista como propiciadora de stress. Além disso, quando buscamos pesquisas voltadas ao estudo do desempenho de telejornalistas e suas competências profissionais, constatamos a ausência também nesse campo.

Com o objetivo de contribuir para os estudos no campo da Psicologia Social e do Trabalho, buscou-se, primeiramente, analisar o processo de stress nos profissionais de telejornalismo, os níveis de desempenho profissional e a correlação entre eles. De que modo o stress afeta o desempenho em telejornalistas? Qual o padrão de desempenho definido pela empresa e o que é esperado deles? Os repórteres e repórteres cinematográficos, por serem profissionais que atuam conjuntamente, porém com graus de responsabilidade distintos, teriam aspectos em comum no que se refere ao stress e ao desempenho? 
Num segundo momento, novas reflexões vieram somar-se ao desenvolvimento do trabalho. Profissionais com bom nível de desempenho tenderiam a apresentar bom nível de competência e menor nível de stress, por manifestarem melhor nível de coping (3)? Qual o padrão de comportamento do telejornalista e sua relação com o stress?

Com vistas a investigar essas questões e relatá-las nesta dissertação, o texto foi dividido em partes. O capítulo inicial é uma introdução, em que se busca contextualizar os conceitos de stress e desempenho à luz da evolução histórica dos paradigmas tradicional e emergente de gestão de empresas. Em seguida serão abordados aspectos da cultura organizacional para a análise do stress e do desempenho. Na seqüência serão desenvolvidas as bases conceituais sobre stress, competência e desempenho, quando então direcionamos o trabalho especificamente para o telejornalismo. Depois serão apresentados os objetivos gerais e específicos e o método empregado na pesquisa. Finalmente, os últimos capítulos referem-se aos resultados e sua discussão, com a estatística dos dados, as análises de significância e as matrizes de intercorrelações. Por último, mostraremos as conclusões do presente estudo.

(1) Adotou-se a grafia stress, em inglês, de acordo com a nomenclatura internacional.

(2) As palavras derivadas de stress (estressor, estressante etc.) não serão grafadas na forma aportuguesada, por se optar em manter a raiz da palavra stress.

(3) Esforços de enfrentamento. O termo coping será utilizado de acordo com a nomenclatura internacional. 


\section{INTRODUÇÃO}




\section{CONTEXTUALIZAÇÃO}

O ser humano é ao mesmo tempo único e específico, como espécie, e pluridimensional, enquanto ser biopsicossocial, que aparece profundamente em interação com o contexto social e a cultura que o envolve, que ele constrói e transforma.

É um ser integral, tal como afirma Chanlat (1996, p. 28) - "cada indivíduo carrega consigo (...) o formato inteiro da humanidade" -, e é simbólico, ao mesmo tempo, pois produz representações do mundo e lhes confere significação. Seu comportamento tem caráter dialético, pois, do mesmo modo que edifica e influencia o universo social numa relação recíproca, gera conflitos e contradições que se registram ao longo da história das sociedades e das organizações.

O universo organizacional é um dos campos em que duas dimensões fundamentais da humanidade concreta estão representadas: a atividade da reflexão e a subjetividade em ação, e é também nesse contexto que se desenvolve a interação coletiva compartilhada, em que o indivíduo busca compatibilizar o seu "ser" com desejos, pulsões e aspirações próprias, com os ritos e a cultura organizacional, circunscritos aos valores e possibilidades (CHANLAT, 1996).

O indivíduo é ator de sua própria experiência e vivências, mas nem sempre estabelece seus próprios limites com muita clareza, o que pode atingir e que preço estará disposto a pagar para consegui-lo.

As organizações exercem papel na construção de uma ordem social, e essa ordem social perpassa a ordem organizacional, cuja dinâmica pode mudar de acordo com uma ordem ainda maior, a internacional, à qual ela pertence (CHANLAT, 1996).

Dentro de uma visão histórica, as organizações se apoiaram e se fundamentaram em diferentes paradigmas de gestão, que tiveram reflexos e consequiências para os trabalhadores tanto no nível do desempenho profissional quanto no dos sintomas desencadeadores de stress psicossocial.

Chanlat (1995) diferencia quatro modelos de gestão (tayloriano, tecnoburocrático, excelência/eficácia e participativo), que serão demonstrados a seguir, e os define como um conjunto de práticas administrativas colocadas em execução para atingir os objetivos organizacionais, que compreendem: filosofia, valores, políticas, sistemas de avaliação e controle 
dos resultados, estrutura hierárquica, organização e condições de trabalho. Nossa proposta é incluir no decorrer dessa introdução, o paradigma atual e emergente de gestão de empresas, de modo a contextualizar as visões que influenciaram o comportamento do homem nas organizações e que deixaram consequiências com as quais nos deparamos tanto na dimensão da manifestação do stress quanto na do desempenho no trabalho.

\subsection{Modelos de gestão}

\subsubsection{Paradigma tradicional - o modelo de gestão tayloriano $\mathrm{e}$ a relação stress $\mathrm{x}$ desempenho}

Grandes transformações no mundo do trabalho datam do século XVIII, quando a sociedade de característica rural e artesanal se transforma em sociedade urbana e o trabalho passa a ser em escala industrial. Foi um momento que afetou significativamente a relação entre homem e trabalho, pois o homem, até então inserido no núcleo familiar, mantinha-se distanciado do contexto econômico competitivo, que retrata a era contemporânea. Um dos cernes dessa mudança foi a submissão do operário a um tipo de controle ao qual não estava habituado e às condições adversas de trabalho para ganhar o seu sustento e sobrevivência.

"O artesão, que passa a operador, deixa de ser o mestre da produção do seu próprio negócio para se tornar subordinado a uma nova condição de vida, a um outro ritmo de atividade, a outros valores e com uma demanda profissional por diferentes habilidades, demanda esta que acabou por criar outros problemas para o homem" (MALVEZZI, 1988).

Novas crenças, nova racionalidade e novo padrão de exigência no trabalho passaram a existir. Com o fim do século XIX, o modo de organização do trabalho altera-se com a substituição das máquinas a vapor pelas movidas a óleo diesel - "era da eletromecânica" - e quando os processos de controle da produção passam a seguir o modelo de gestão tayloriano da administração científica, com ênfase no desempenho da tarefa, cada vez mais repetitiva e constante, sob pressão por maior velocidade, ritmo, capacitação e controle sobre sua eficácia (MALVEZZI, 1999).

Essa mudança exigia jornadas de trabalho mais longas, sem descanso semanal e sem direitos trabalhistas regulamentados, o que tornava precária a qualidade de vida no trabalho. O indivíduo apresentava sérios problemas de adaptação à máquina e não tinha habilidades específicas para diferentes tarefas, nem conseguia se adequar à falta de sensibilidade da 
supervisão. A fadiga, que hoje vincularíamos a um sintoma de stress no trabalho, era um sério obstáculo ao desempenho e acarretava problemas de saúde, queda da produção e absenteísmo. Algumas décadas à frente, por volta de 1936, o fisiologista Hans Selye descrevia o fenômeno biológico do stress na sua concepção científica e analisava as reações que o organismo desenvolve ao ser submetido a tais esforços de adaptação.

Hugo Munstemberg, considerado o pai da psicologia organizacional, publicou o primeiro livro sobre estudo do desempenho em 1913, Psychology and Industrial Efficiency, em que enfatizava a engenharia do desempenho. Tratava-se de procedimentos rigorosamente técnicos, voltados para a mensuração de variáveis pré-definidas e previsíveis do processo de produção, em que a condição psicológica do trabalhador era mais uma dessas variáveis, logo não se considerava o contexto psicossocial (MALVEZZI,1999).

Ainda que seja inaceitável, nos dias atuais há empresas dos setores da indústria e de serviços que praticam o modelo de gestão neotayloriano, com ênfase no "homem econômico", em que o trabalhador é considerado por sua capacidade física e visto unicamente por sua motivação econômica (CHANLAT, 1995). O caráter repetitivo das tarefas, a pressão do tempo, a intensa carga física e mental, a ausência de autonomia e de expressão, o excesso de controle sobre o desempenho são aspectos inerentes a esse modelo e desencadeiam problemas relacionados à fadiga crônica ou nervosa, entre outras doenças psicossomáticas.

\subsubsection{O modelo de gestão tecnoburocrático}

A evolução da tecnologia ao longo do século XX demandou adaptações fundamentais dos sujeitos aos processos de produção, que passaram da mecanização à automação.

O modelo de gestão tayloriano foi substituído em algumas organizações pelo tecnoburocrático, que enfatizava o "homem racional". Suas principais características são: a racionalidade, a estrutura hierarquizada, a burocracia, as divisões do trabalho por especialistas e técnicos, que se guiavam por normas e manuais rígidos, controles diferenciados, centralização de poder, fraca autonomia, baixa participação do trabalhador e excesso de trabalho. A avaliação de desempenho nesse modelo é considerada um recurso técnico de controle de gestão de pessoas, e as organizações que mantêm as práticas neotaylorianas aliadas às tecnoburocráticas geram fadiga e elevado nível de stress profissional, que pode levar à exaustão. 
Esse modelo é ainda praticado nos dias atuais e atingem os trabalhadores, principalmente os de menor qualificação técnica e baixa escolaridade, que não conseguem espaço para ascensão na estrutura hierárquica e que se submetem a precariedade de contratos.

\subsubsection{O modelo de gestão da excelência/eficácia e o modelo participativo}

A partir dos anos 60, o mundo viveu intenso desenvolvimento, impulsionado pela conjuntura econômica. Os meios de comunicação ganhavam espaço e a televisão competia com a imprensa. A escalada técnico-científica e tecnológica, a expansão da automação nas indústrias e o surgimento do computador imprimiram maior agilidade aos processos de trabalho, o que significava ganho sobre os controles e maior integração dos sistemas de produção. Por outro lado, passou-se a requerer dos sujeitos enorme flexibilidade e grande capacitação para adaptar-se às tarefas multifuncionais e à polivalência (SALERNO, 1994).

Novas práticas administrativas surgiram nesse cenário, como a gestão da excelência e eficácia dos resultados e o modelo participativo. O modelo de gestão da excelência/eficácia caracteriza-se pela qualidade total, a valorização do êxito e do fazer melhor. A avaliação de desempenho por objetivos é o instrumento desenvolvido para esse modelo de gestão e é atrelada às recompensas materiais e simbólicas individualizadas. O modelo participativo, segundo Chanlat (1995), visa minimizar o distanciamento das estruturas hierárquicas e enfatiza o trabalho em equipe, a maior autonomia no trabalho e a co-responsabilidade dos sujeitos.

Ambos os modelos exigem um novo perfil de atuação do indivíduo, voltado para a motivação, mobilização e comprometimento total com a organização, e ainda que considerem aspectos muito positivos como reconhecimento e valorização do indivíduo por seu desempenho, geram tensão, pois o sujeito é desafiado a enfrentar situações de pressão permanentes e o contínuo ajustamento às exigências do ambiente.

\subsubsection{Cenário atual - o paradigma emergente de gestão de empresas, condições de trabalho e o desempenho profissional}

A instabilidade do mercado se acelerou predominantemente após os anos 80 , com o crescimento do capitalismo financeiro e da globalização, atrelado ao processo de internacionalização, à fusão de empresas, ao avanço tecnológico das telecomunicações 
(telefonia), dos veículos de comunicação de massa (televisão, rádio, publicidade, propaganda) e essencialmente ao sucesso da internet.

A prática de gestão passa a caracterizar-se por um processo de transição drástico, o paradigma atual e emergente (MALVEZZI, 2004). As mudanças aceleradas têm contribuído para que o novo cenário do trabalho se apresente como um mosaico (SATO, 2002), em que o velho e o novo se mesclam. É um cenário em que o paradigma tradicional dialoga com o emergente, na medida em que as empresas se utilizam de ações de gestão híbridas e oscilam entre ações participativas e atitudes autoritárias. Ou seja, coexistem na mesma empresa estruturas fortemente hierarquizadas, com centralização do poder e da tomada de decisões, e ações mais democráticas, como a avaliação do desempenho dos funcionários com base na autonomia e na criatividade .

Outro aspecto que caracteriza o paradigma emergente de gestão de empresas, segundo Rousseau (1997), é o contrato empregatício de vinculo frágil e de curto prazo, assim como a descontinuidade e a instabilidade social que se refletem na construção da identidade dos sujeitos, que os levam a um processo de ressignificações permanentes, para saber atuar nesse cenário.

Nas organizações atuais, a grave ameaça que paira é não sobreviver às novas configurações e leis do mercado e sucumbir a outras empresas mais fortes. No mercado de comunicação, por exemplo, a concorrência com emissoras de TV a cabo, empresas de telecomunicações, e principalmente a internet, tem sido cada vez mais acirrada. A situação de ameaça das empresas de modo geral é tamanha que, segundo Losicer (1995), gera uma angústia que permeia todos os sintomas no contexto do trabalho, tanto na esfera individual (pressão e stress) quanto na esfera organizacional (busca permanente pela produtividade e desempenho).

Pelas questões acima mencionadas, o trabalho passa a ter importância central na vida das pessoas e não apenas dita o estilo de vida, como determina o presente e projeta o futuro. Segundo Malvezzi (1999), "o trabalho é reconhecido como algo fundamental, é um meio para transformar o mundo em que o ser humano depende para alcançar suas possibilidades de vida. (...) É algo que tem um significado bastante importante para a vida humana, seja por questão de sobrevivência, seja porque é um dos instrumentos de adaptação do individuo".

Nesse sentido, o acompanhamento do desempenho, do desenvolvimento profissional do sujeito e o cuidado com as fontes geradoras de stress ganharam mais importância com a evolução do paradigma emergente. A partir do momento em que o indivíduo assume o trabalho como algo desafiador, como depositário de suas realizações, buscará ser reconhecido dentro da 
empresa. E a empresa tenderá a estimular o crescimento da sua identidade e ajudá-lo a construir o seu projeto profissional na própria empresa (MALVEZZI, 1994).

O que se verifica nos dias atuais é uma crescente busca pela relação de reciprocidade entre o indivíduo e a organização.

\subsubsection{O paradigma emergente de gestão de empresas e o telejornalismo}

A partir dos anos 90, as redações de telejornalismo evoluíram para a informatização, a virtualização de cenários, a digitalização de imagens e a transmissão feita em padrão de alta definição e qualidade. A compressão do tempo e do espaço provocada pela internet contribuiu para que os telejornalistas reproduzissem informações e notícias com instantaneidade.

O telejornalismo é exemplo de contexto em que o modelo emergente de gestão de empresas se concretiza, por sua inconstância, instabilidade, imprevisibilidade, por imprimir forte pressão de urgência de tempo, qualidade e precisão, e também por exigir dos sujeitos, entre vários fatores, foco em resultados, flexibilidade de adaptação a situações complexas, senso de autonomia, independência, postura empreendedora, tomada de decisão, ritmo ágil e criatividade.

Analisando-se o telejornalismo sob a ótica dos cinco modelos de gestão de empresas anteriormente apresentados, identificaremos que o paradigma emergente é o que melhor caracteriza o momento atual. O primeiro modelo, o de gestão tayloriano, é apropriado a atividades rotineiras e mecânicas, mas incompatível com o trabalho jornalístico, em que não existe rotina.

No modelo tecnoburocrático seria inviável cumprir regras e manuais de forma rígida, dada a imprevisibilidade dos fatos, além da burocracia, que impediria respostas ágeis e tomadas de decisão adequadas ao momento jornalístico. O desempenho do repórter no contexto atual dependerá muito mais dele mesmo do que dependeria numa situação na qual ele tivesse de seguir os procedimentos de um manual.

No modelo de gestão da excelência e eficácia prevalece a definição de planos e metas muito claros e definidos para que os objetivos possam ser atingidos, e o dinamismo do contexto telejornalístico por requerer grande adaptabilidade a mudanças, nem sempre se ajusta a esse modelo. Já o modelo participativo é mais próximo da realidade do telejornalismo, pois leva a consulta nas tomadas de decisão, porém obter o consenso, também retardaria enormemente a agilidade das decisões, uma vez que o repórter precisa dispor de senso de autonomia, 
independência e flexibilidade para trazer respostas rápidas ao público sobre fatos, entrevistas, fontes adequadas etc.

O modelo emergente privilegia um perfil de telejornalista com ampla gama de habilidades e características fortemente realizadoras, colaboradoras e criativas, um profissional que compartilha da cultura e dos valores organizacionais. A valorização das melhores reportagens e o reconhecimento do repórter pelo trabalho jornalístico realizado com seriedade e correção são atributos que caracterizam o modelo de gestão participativa, todavia de modo ainda mais acentuado no modelo emergente de gestão de empresas, no qual o foco na competência, no desempenho individual, em equipe e nos resultados são fatores determinantes do sucesso do negócio.

A ação do repórter no modelo emergente é mais livre de balizamentos externos e mais dependente da racionalidade que ele cria para seu trabalho e para si mesmo. Seu empenho em realizar uma tarefa é ativado, ou não, em proporção direta ao significado que ele atribui ao conteúdo e particularmente ao seu projeto de vida (MALVEZZI, 1994).

\section{CULTURA ORGANIZACIONAL, CONFLITO DE GESTÃO E STRESS}

A cultura da empresa, o modelo de gestão adotado e o ambiente de trabalho são fatores que irão orientar a conduta do telejornalista, suas expectativas de desempenho e seu papel a cumprir.

Conceitualmente, a cultura organizacional, segundo Santos (2000), é um poderoso instrumento para predizer o comportamento dos seus membros. A cultura é única, própria da empresa e funciona como um mecanismo de controle sobre os indivíduos.

Para Enriquez (1992), os mecanismos de controle podem ser afetivos e intelectuais e são necessários para manter a solidez da organização. A cultura possibilita um processo de formação e socialização das pessoas, sedimenta a ação dos membros, que legitimam e dão significação preestabelecida às práticas, à identidade e existência da organização. Graças a essa interiorização dos valores culturais, os sujeitos poderão viver os sentimentos de pertença, experimentar a admiração ou temor pelos chefes, dedicar-se plenamente às suas atividades e comportar-se como "heróis". Para o autor, o indivíduo precisa buscar o equilíbrio entre si e a empresa, saber 
distanciar-se para poder refletir sobre seus valores. Para o autor, a adesão total à organização provoca uma tensão nervosa, um grande desgaste emocional, que pode levar ao burnout (1), na medida em que a pessoa entra em conflito ao tentar mostrar seu poder e sua força diante dos da empresa (p.51).

Tamoyo (2004) analisou o nível de stress no ambiente do trabalho e verificou que é ele determinado em grande parte por elementos da cultura e do clima organizacional. Esses elementos da cultura são as atividades de trabalho, normas, estilo de gestão, valores e configuração de poder. Segundo o autor, o nível de stress varia de pessoa para pessoa, mas resulta da relação entre as exigências do trabalho e o repertório do sujeito para enfrentar a situação stressora e depende da intensidade, frequiência e duração da exposição. A liderança gerencial e as políticas adotadas interferem sobremaneira no clima, no nível de stress dos sujeitos e modificam o impacto dos eventos stressores.

Mendes (2004), que estudou a cultura organizacional segundo a abordagem psicodinâmica, considera que a cultura é uma oportunidade de os sujeitos projetarem seus desejos e necessidades, muitas vezes inconscientes, implicando processos de simbolização que envolvem o jogo subjetivo entre a realidade psíquica e a organizacional. Quando a cultura organizacional privilegia valores como autonomia, cooperação, expressão da subjetividade individual, justiça e harmonia, ocorrem mais vivências de prazer.

O prazer é um indicador positivo do bem-estar do sujeito que pode sofrer influência ou não da cultura organizacional, porém esse sentimento gera oportunidades de fortalecimento da identidade pessoal através das possibilidades de realização e liberdade. A realização é definida pela autora como o sentimento de orgulho e identificação com o trabalho que atende às necessidades profissionais, enquanto a liberdade é a possibilidade de estar livre para pensar, sentir e agir.

Conforme Mendes e Cruz (2004), o sentido que o trabalho assume para algumas categorias profissionais pode ser fonte de prazer e satisfação, se há investimento psicoafetivo na atividade desenvolvida e um fluxo contínuo de sentimentos positivos em resposta ao ambiente. Pode-se dizer que atuar em telejornalismo tem essa conotação e tem gerado sentimentos de orgulho e paixão pela profissão. Muitos telejornalistas, sobretudo os investigativos, continuam na atividade por muitos anos e com dedicação absoluta, embora enfrentem represálias e ameaças pelas denúncias que apresentam. 
Se a cultura organizacional enfatizar em demasia o conservadorismo, a pressão por produtividade, e se houver inflexibilidade e excesso de autoritarismo na gestão, voltados principalmente para os interesses da racionalidade econômica, as vivências de sofrimento e pouca liberdade de ação agirão como fortes stressores, com grande interferência sobre o desempenho (FERREIRA E ASHMAR, 2004).

Nenhuma empresa atualmente está imune aos efeitos potencialmente devastadores do cenário volátil e incerto em que se insere. Antes as empresas de mídia eram disfuncionais, mas funcionavam. Hoje é diferente. Os líderes têm dificuldade de antever o futuro e de determinar os resultados, e a dinâmica organizacional afeta todos, os gerentes e as funções operacionais mais importantes. Segundo WHEATLEY (2006), na medida em que as pessoas estão frágeis e temerosas, esperam dos gestores habilidade emocional e capacidade de manter níveis decentes de produtividade, e para estes, quando se deixam levar pelas dificuldades organizacionais, é mais complexo inspirar confiança e credibilidade nas pessoas.

A autora aponta que para combater a dinâmica organizacional negativa, estimulada pelo stress e pela incerteza, é fundamental que se dê atenção à qualidade das relações de confiança, de colaboração e de reciprocidade entre as pessoas e que o princípio básico para desenvolver essa ligação é as pessoas estarem envolvidas num trabalho significativo, em que os propósitos e os valores da organização sejam mantidos em evidência e façam sentido para elas.

"É essencial que a empresa fomente processos que reúnam as pessoas, de modo que elas conheçam os pontos de vista e os desafios umas das outras. Se a organização não estimular esses processos, as pessoas continuarão numa espiral descendente, que terá um impacto devastador sobre o desempenho. Sufocadas pelo volume de tarefas, as pessoas perdem de vista o significado do trabalho e se vêem isoladas e sozinhas. Embora mais ocupadas e frenéticas, produzem basicamente stress. Além disso, a inteligência individual e organizacional declina drasticamente quando se perde de vista o contexto geral do trabalho" (Wheatley, 2006, p.110).

Na próxima etapa do trabalho, procuramos aprofundar as bases teóricas do stress e do desempenho, para, na seqüência, direcionarmos especificamente para o estudo do telejornalismo.

(1) Burnout: sensação de crescente exaustão emocional. 
III. FUNDAMENTAÇÃO TEÓRICA 
Primeira Parte-STRESS

\section{CONCEITUAÇÃO}

Uma grande questão ontológica, inerente ao ser humano, tem sido a problemática de adaptação e da competência em conquistar a sobrevivência. Como evidencia Goldberg (1986), "mudamos o ambiente mais depressa do que sabemos mudar a nós mesmos".

A adaptação, segundo Lazarus (1974), é o processo por meio do qual dominamos as exigências externas que nos são impostas, que funcionam como poderosas pressões e que terão que ser ajustadas, se quisermos usufruir uma relação confortável e efetiva com o ambiente. Para o autor, avaliar a propriedade de adaptação do individuo é um dos mais difíceis e provocantes problemas da humanidade.

O termo stress veio em resposta à necessidade do indivíduo de ajustamento, equilíbrio e adaptação ao meio. É um desequilíbrio substancial entre a capacidade de demanda e a resposta, sob condições em que a falha em responder adequadamente tem consequiências importantes.

Ao longo da história, as pessoas sempre foram submetidas a fortes demandas de adaptabilidade na medida em que se defrontavam com agentes stressores capazes de produzir fatores como o medo de situações novas, e também tinham de enfrentar variações ambientais de calor e frio, diferentes condições de trabalho, dor, conflitos, necessidades afetivas, humilhação, fadiga, desemprego, escassez de alimentos, epidemias, doenças, guerras, emoções de alegria e felicidade, sucesso etc. Contemporaneamente, as pessoas dizem ter dificuldade em conseguir uma bem-sucedida adaptação porque o homem tem sido submetido a pressões gigantescas, estímulos rápidos e tal condição tem levado a uma grande sobrecarga no organismo (GOLDBERG, 1986).

Consideramos três dimensões do stress, a fisiológica, a psicológica e a biopsicossocial, mas daremos ênfase à dimensão biopsicossocial por ser a mais integradora das abordagens. Vasconcellos (2002) apresenta um modelo de stress ligado à psiconeuroimunologia, inserido numa abordagem biopsicossocial. Ele caracteriza o stress como "alteração fisiológica que se processa no organismo quando este se encontra em uma situação que requeira dele uma reação mais forte que aquela que corresponde à sua atividade orgânica normal". O processo biopsicossocial do stress é desencadeado por estímulos sócio-ambientais, relacionados aos conflitos de gestão e à natureza da tarefa (stressor exógeno) e por fatores internos do próprio 
indivíduo (stressor endógeno), que provocam aumento de demanda das atividades vitais do organismo, gerando reações de desequilíbrio homeostático.

O conceito de homeostase data de 1929, quando o fisiologista Cannon diferenciou "um eficiente sistema de ativação, feedback e auto-regulação dinâmica que garante o funcionamento biológico regular do organismo". Passado quase um século da proposição de Cannon sobre homeostase, Vasconcellos (2000), ao considerar os stressores exógenos e endógenos, reavalia que o processo de homeostase do organismo deveria ser caracterizado pelo "estado de relativo equilíbrio ou de desequilíbrio do organismo", dado que o corpo humano não permanece totalmente em repouso, mas em processo de dinamismo intrínseco constante, em que a interferência da cognição e de processos emocionais conscientes e inconscientes são permanentes.

\section{AS FASES DO STRESS}

Foi o endocrinologista Hans Selye que, em 1936, pela primeira vez descreveu, na revista Nature, o fenômeno do stress na sua concepção científica como "uma síndrome produzida por agentes prejudiciais diversos", mais adiante conhecida como "síndrome de adaptação geral" (SAG). Selye (1986) definiu o stress como um conjunto de reações que um organismo desenvolve ao ser submetido a uma situação que exige esforço de adaptação e identificou na síndrome três estágios de processo adaptativo: reação de alarme, resistência e exaustão.

Do ponto de vista sistêmico, os agentes stressores levam o organismo a um aumento de maior rigidez muscular no estágio de alarme, na medida em que se prepara para enfrentar o desafio, e, se estiver saudável, o organismo retomará seu equilíbrio, seu relaxamento e restabelecerá a flexibilidade depois de passada a ameaça, o que é conhecido como resposta de fight or flight (luta ou fuga). Nesse momento haverá uma intensa descarga hormonal e, se o organismo se mantiver em exposição continuada ao agente stressor, seguirá ao estágio de resistência em que os reguladores internos buscarão o nível de adaptação à atividade orgânica. Porém, em vez de o organismo mobilizar-se de forma geral (SAG), passará a direcionar sua reação interna a um único órgão do corpo, geralmente o mais frágil e predisposto ao adoecimento - "síndrome de adaptação local" (SAL). 
Ainda sob atividades extremamente stressantes, o organismo segue para o terceiro estágio de adaptação, a exaustão. Embora o sono e o descanso possam restaurar a resistência e a adaptação a níveis muito próximos dos níveis precedentes, as atividades biológicas se desgastam e deixam cicatrizes químicas irreversíveis (SELYE, 1986). Se o stress for prolongado ou crônico, pode anular o sistema imunológico do corpo e suas defesas naturais e desempenhar um papel significativo de envelhecimento e risco à saúde.

Como já mencionado, as fontes de sobrecarga de stress podem estar no indivíduo, no ambiente interno de trabalho ou na natureza da tarefa, relacionando-se ao grau de exposição do sujeito ao ambiente externo/sociedade.

O stress não resulta somente de experiências negativas. Todos os eventos, tristes ou alegres, podem desencadear reações rápidas de adaptação e mudanças profundas no sujeito e levá-lo ao processo de stress. O eustress consiste na reação saudável de "bom stress", provocada por situações agradáveis, uma vez que de uma grande excitação resulta a satisfação, a sensação relaxante de dever cumprido, o prazer, o desenvolvimento emocional e intelectual, ou seja, corresponde ao nível natural da atividade orgânica (VASCONCELLOS, 2002). Esse stress é positivo e geralmente maximiza o desempenho dos sujeitos, levando-os a resultados construtivos.

Muitos repórteres enfrentam situações de entrada ao vivo, em que têm reações fisiológicas (suam, ficam alguns segundos gaguejando), mas transmitem a informação de forma correta e, ao concluírem o trabalho, sentem uma sensação relaxante de que tudo deu certo e de que a redação toda estava apostando neles. Essa é uma situação que pode ser caracterizada como exemplo de eustress diário.

Já o distress, ou o "mau stress", pode ser provocado por exigências inadequadas ou exageradas e definido como o stress danoso (SELYE, 1986), prejudicial, que consome as energias e provoca o rompimento do equilíbrio biopsicossocial. $\mathrm{O}$ que diferencia basicamente o eustress do distress é a intensidade, a freqüência, a duração da exposição e especificamente a falta de controle do indivíduo sobre a situação stressante.

Feinstein (2002) estudou os sintomas de distress psicológico nos jornalistas de guerra. $\mathrm{O}$ autor acredita que uma reportagem de guerra seja completamente diferente da cobertura de uma devastação como as provocadas por tsunamis ou furacões, porque nessas situações não há o sentido de ameaça pessoal. $\mathrm{O}$ mesmo significado da cobertura de guerra pode existir para o 
sujeito que faz a cobertura de um tiroteio em morro, em que a variável "ameaça pessoal" é muito intensa e a reação emocional pode gerar distress. A realização de coberturas de rebeliões, como a do Carandiru, é algo marcante. Na ocasião, cerca de 25 mil detentos em presídios de 19 cidades do estado de São Paulo estavam rebelados há mais de oito horas e a tropa de choque da polícia entrou na maior penitenciária da América Latina, espalhando gás lacrimogêneo para afastar os familiares que forçavam os portões do presídio. Muitos repórteres e repórteres cinematográficos tiveram sentimentos de dano e ameaça pessoal naquele momento.

\section{DIMENSÃO FISIOLÓGICA DO STRESS}

Nitsch e outros autores (1981) demonstram que a dimensão fisiológica do stress está relacionada aos mecanismos de dois sistemas que interagem: o sistema nervoso central - via neural - e o sistema de glândulas endócrinas - via neuro-humoral. O stress representa uma reação orgânica não ligada a sistemas isolados e tem como seus principais eixos transmissores o eixo hipotálamo-hipófise-supra-renal, cujo hormônio ACTH e os glicocorticóides (principalmente o cortisol) têm importância central, e o eixo hipotálamo-medula a supra-renal, cuja relevância está nas catecolaminas (adrenalina e noradrenalina). Os dois eixos são acionados em conjunto e quase todos os órgãos endócrinos são mobilizados na reação ao stress. O efeito do stressor do ponto de vista fisiológico depende da sua nocividade, da predisposição do organismo, das reações de funcionamento entre os sistemas envolvidos e das exigências e objetivos concretos de adaptação.

No eixo hipotálamo-hipófise-supra-renal, a reação fisiológica ao stress é desencadeada pela presença do stressor, que é informada ao tálamo, que inicia um elevado nível de excitação dos núcleos hipotalâmicos. O hipotálamo tem um papel fundamental no processo de reação ao stress fisiológico. Alguns grupos de células hipotalâmicas formam neurosecreções ou fatores de liberação, como o CRF ou fator corticotrópico de liberação $(\mathrm{CRH})$, que estimulam, através da permeação, diversas células histoquimicamente diferenciadas, formadoras de hormônios do lóbulo anterior da hipófise e são transportadas para a adeno-hipófise.

$\mathrm{Na}$ adeno-hipófise, devido aos estímulos RF (fatores de liberação) são formados: STH (hormônio do crescimento), hormônios glandotrópicos e o ACTH (hormônio adrenocorticotrópico). O ACTH, entre várias funções, promove o crescimento do córtex da 
glândula da supra-renal e a formação de mineralocorticóides e corticosteróides, principalmente a aldosterona e o cortisol. O cortisol (hidrocortisona) é o glicocorticóide em maior quantidade na corrente sangüínea e o mais produzido pelo organismo no momento de reação ao stress.

Ele apresenta vários efeitos sobre o organismo: tem a importante função de metabolizar os carboidratos, de decompor os ácidos graxos/gorduras do tecido adiposo e as proteínas dos músculos, para realizar a glicogênese (formação de açúcares); estimula a produção de glicogênio no fígado, processo que é chamado de neoglicogênese, liberando glicose para a corrente sangüínea; inibe a produção de insulina no pâncreas, portanto mobiliza as energias que o organismo dispõe e as coloca a serviço dos músculos, coração e demais órgãos vitais, para que mantenham o organismo apto a enfrentar o stressor; influencia no processo de defesa celular e sangüínea, bem como inibe o sistema imunológico.

No eixo hipotálamo-medula da supra-renal, a reação fisiológica do stress também se inicia com um elevado nível de excitação dos núcleos hipotalâmicos, que ativam os axônios préganglionares do sistema nervoso simpático, que chega à medula supra-renal (NNM), que é o órgão central do sistema neural. A NNM produz as catecolaminas adrenalina e noradrenalina, que são neurotransmissores importantes, reguladores do sistema cardiovascular e mediador do sistema nervoso central e dos nervos autônomos. A reação de aumento das catecolaminas é verificada diante de estímulos stressores emocionais ou por qualidade emocional seletiva, em que se observa uma descarga dez vezes mais intensa do que em repouso, também diante de atividade muscular e de situação de pronta ação (luta ou fuga).

\section{DIMENSÃO PSICOLÓGICA DO STRESS}

A abordagem psicológica do stress relaciona fortemente os aspectos fisiológicos e psicológicos e agrega a visão conceitual dos fisiologistas, que em princípio correspondia à "síndrome de adaptação geral", de Hans Selye, e não contemplava as emoções e os fatores psicossociais como componentes da análise do stress.

Segundo Lazarus e Folkman (1984), o stress ocorre quando os recursos disponíveis da pessoa estão aquém das demandas do ambiente, no plano físico, emocional ou social, prejudicando seu bem-estar. Os autores revelam que o ser humano tem como condição ontológica a capacidade de sobrevivência e de desenvolvimento e, como consequiência, precisa 
distinguir as situações para encontrar o sentido de adaptação bem-sucedida e de bem-estar pessoal. As demandas e pressões do ambiente produzem stress de maneira diferente nas pessoas, pois cada pessoa constrói uma situação conforme suas percepções avaliativas.

Apontam esses autores que essa possibilidade se dá através da evolução cerebral e de um eficiente sistema cognitivo, capaz de julgamentos simbólicos, fortalecidos pelo aprendizado e pelas experiências de vida dos sujeitos. O impacto nas pessoas e nos grupos varia de acordo com a sensibilidade, vulnerabilidade e a maneira como interpretam cognitivamente as situações. As reações de equilíbrio ou desequilíbrio adaptativo não são apenas determinadas por respostas imediatas e não deliberadas provenientes dos estímulos ambientais, mas passam por um filtro ou mediação cognitiva.

Consideram que a avaliação cognitiva se desenvolve em três fases: a avaliação primária, a avaliação secundária e a reavaliação. A avaliação primária ocorre no nível do sistema límbico, tálamo e hipotálamo, e classifica o stressor como irrelevante, benéfico ou prejudicial. A avaliação irrelevante e benéfica está associada a emoções agradáveis, prazerosas e o indivíduo não avalia nenhuma possibilidade de ameaça ao seu bem-estar. Quando a avaliação cognitiva for de prejuízo, o indivíduo avalia a situação stressora de três formas, como uma situação de dano/perda - que se refere ao fato ocorrido e assumido pelo indivíduo; uma situação de ameaça quando o dano tem implicações negativas para o futuro; ou uma situação de desafio - em que o foco está no potencial de ganho ou de crescimento.

A avaliação primária de ameaça é caracterizada por medo, ansiedade e raiva, enquanto a de desafio é de vontade e excitação. O desafio, diferentemente da ameaça, tem importantes implicações adaptativas, na medida em que gera moral elevado, entusiasmo, independência e confiança do indivíduo em si mesmo. O desafio traz o sentimento de o repórter ou repórter cinematográfico poder demonstrar suas competências "por inteiro", principalmente quando é possível a realização de matérias que possibilitam viajar pelo país e exterior: as chapadas, os mangues, as fronteiras, as danças regionais são trabalhos mais elaborados, que impõem maiores desafios, como a qualidade da apuração e o desenvolvimento do estilo.

No processo de avaliação de uma situação, o indivíduo, com base em vivências anteriores, dá um significado ao momento que está sendo vivido, que será determinante na maneira como vai enfrentá-lo, assim como o tipo e a intensidade da resposta. O teste LSS/VAS, 
que foi aplicado nesta pesquisa, permite a análise de respostas dos sujeitos que avaliaram o significado, a intensidade e a freqüência dos sintomas de stress.

Se o indivíduo consegue elaborar um coping adequado da situação e lidar eficazmente com a situação stressante, o nível de stress será reduzido. Um coping adequado pode ser ilustrado, quando o repórter, ao fazer uma entrada ao vivo, consegue demonstrar tranquiilidade, diminuir o ritmo dos seus batimentos cardíacos, falar devagar para não confundir o telespectador e se concentrar de acordo com o que a situação exige.

Do contrário, o stress aumentará e serão necessários recursos internos para fazer frente ao stressor, com a avaliação secundária. Nesta fase, o processamento da avaliação é complexo. Dá-se no nível cortical e leva em conta se as estratégias de coping disponíveis são adequadas para a situação stressante. A reavaliação acontece quando os resultados de eficácia ou fracasso da situação ficam claros para o indivíduo e este pode reformular as estratégias utilizadas ou não.

De forma prática, o estudo de Eysenck (1988) demonstrou que a intervenção de técnicas cognitivas de enfrentamento (coping) em indivíduos com elevado nível de stress pode auxiliar na avaliação cognitiva dos sujeitos, contribuir com a redução do nível de cortisol e de outros hormônios do stress e favorecer a resistência imunológica.

\section{DIMENSÃO BIOPSICOSSOCIAL DO STRESS}

Lazarus e Folkman (1984) levam em conta três níveis ao analisar o stress: o fisiológico (fatores genéticos, condicionamento fisiológico, fatores de risco, recursos imunológicos, vulnerabilidade, alterações somáticas etc.), o psicológico (variáveis de personalidade, demandas situacionais, crenças, compromissos, recursos materiais, vulnerabilidade, coping centrado no problema ou centrado na emoção, busca de apoio social etc.) e o social (status socioeconômico, cultura, sistema institucional, estrutura grupal, rede sociais, suporte social, pressão, alienação etc). Relacionando esses níveis à capacidade de coping do sujeito, há fatores que influenciam o processo de avaliação, como o compromisso com a situação - quanto maior o compromisso, maior o comprometimento que poderá motivar o indivíduo a desenvolver recursos para enfrentar a situação - e as crenças - convicções pessoais que influenciam a percepção sobre a tomada de decisão na situação. 
Uma valiosa contribuição foi recentemente incorporada à teoria de Lazarus (2000), teoria cognitivo-motivacional-relacional, em que o autor vê o papel das emoções no contexto do stress como algo essencial para o bem-estar biopsicossocial e para os esforços de adaptação da pessoa. Ele reconhece que o stress tem interdependência com a emoção: "se há stress, também estão presentes as emoções" (p.46). Cada emoção contempla uma história pessoal sobre a relação contínua com o ambiente e traduz algo diferente sobre como a pessoa avalia uma situação adaptativa e o seu modo de lidar com ela. O stress, a emoção e o coping são conceitos que coexistem e formam uma unidade conceitual.

Lazarus (2000) pesquisou dois níveis de abstração diferentes mas diretamente relacionados, o significado parcial e o significado relacional sintetizado. Para que uma reação emocional possa ser rápida, o sujeito não pode passar muito tempo se perguntando e respondendo às diferentes questões do seu processo avaliativo, mas deverá sintetizar rapidamente as partes de informação e construir um todo unitário. Em sua teoria, diferencia quinze emoções, como ira, ansiedade, temor, ciúme, inveja, culpa, vergonha, alívio, esperança, tristeza, felicidade, orgulho, amor, gratidão e comparação, em que a avaliação do processo cognitivo se dá num nível de abstração diferente para cada emoção, o que denominou de "tema relacional nuclear". Para o autor, a emoção implica necessariamente a mediação cognitiva do objeto num nível de pensamento/abstração mais complexo e do reconhecimento do significado para o sujeito, bem como do coping.

Le Doux (2001) faz uma distinção importante baseada em várias pesquisas sobre avaliação cognitiva e sintetiza que a emoção e a cognição são mais bem compreendidas como funções mentais mediadas por sistemas cerebrais interativos porém distintos.

A psiconeuroimunologia é uma abordagem científica interdisciplinar que também contempla um sistema integrado entre o somático e o psicológico, que visa à adaptação e defesa do sujeito em interação com o ambiente. Essa área de estudo investiga as interações entre as manifestações cerebrais (mente/conduta), o sistema imunológico e as consequiências clínicas (SOLOMON, 2001).

Vasconcellos (2005), pesquisador do modelo de stress ligado à psiconeuroimunologia, diferencia o cérebro em instâncias distintas de processamento das avaliações: a) na região do bulbo, o cérebro reptílico desencadeia respostas imediatas, instintivas, de comportamento animal, antes de reconhecer se o stressor é bom ou mau e antes mesmo de saber o que é o objeto 
exatamente; b) na região interna do diencéfalo, o cérebro límbico é o grande responsável pelas emoções e se integra ao cérebro cortical no momento das avaliações cognitivas (informação verbal) (1).

\section{STRESS X AMBIENTE DE TRABALHO}

Procurando-se enfatizar a relevância da dimensão biopsicossocial como apresentada acima, tomamos como referência alguns estudos sobre stress que buscam investigar a condição de adaptação do sujeito ao ambiente profissional e os fatores stressores.

A abordagem interacionista do stress, segundo Angerami (2003), utiliza-se do paradigma SOR - S (estímulo), O (organismo) e R (reação) -, que compreende a relação entre agentes stressores em atuação sobre o organismo, que não conseguindo adequadas condições adaptativas reage com distúrbios geradores de doenças.

Magnusson (1982) também se utilizou dessa abordagem e enfatizou a relação entre stress, pessoa e situação, em que é fundamental o entendimento do ambiente real e percebido, bem como das características específicas das situações nas quais o comportamento do indivíduo é investigado. Seu estudo afirma que tanto os fatores socioculturais como os pessoais (idade, maturidade e aprendizagem) regulam a percepção e a interpretação das circunstâncias situacionais e que os determinantes do stress dependem da avaliação perceptiva do indivíduo sobre as condições ambientais stressoras, portanto o que é stressor para alguns indivíduos de uma cultura não é particularmente para outros.

Uma reação de stress dependerá das condições somáticas e psíquicas da pessoa e do seu nível de vulnerabilidade em termos de predisposição fisiológica, assim como da avaliação perceptual-cognitiva e da sua competência de coping, aliadas à qualidade das condições situacionais provocadoras de stress. A vulnerabilidade para o autor é o resultado do processo de maturação e da aprendizagem do indivíduo dentro dos limites de suas potencialidades inatas. Esse conceito de stress se assemelha ao de Lazarus e Folkman (1984): "reações psíquicas e somáticas de um indivíduo às demandas que atingem ou excedem os limites de seus recursos de coping".

Outro exemplo de abordagem interacionista é o modelo de demanda-controle de Karasek (1979; apud LIMONGE E RODRIGUES, 2002), que tem sido um referencial teórico importante 
para os estudos sobre os efeitos do ambiente de trabalho. O modelo de Karasek combina os efeitos nas pessoas com base no nível de demanda e controle do ambiente:

1) Alta Demanda e Baixo Controle = Alta Tensão no Trabalho: o modelo considera que sujeitos que sofrem de alta sobrecarga de exigência no trabalho, associada à baixa latitude decisória (falta de autonomia para tomar decisões necessárias à execução de suas tarefas e falta de liberdade para administrar a seqüência e o tempo de execução do trabalho), têm maior risco de apresentar problemas de saúde decorrentes de stress;

2) Alta Demanda e Alto Controle = Trabalho Ativo: o modelo considera que sujeitos que têm elevado nível de exigência e simultaneamente elevada autonomia desenvolvem novos padrões de comportamento dentro e fora do ambiente de trabalho e maior capacitação;

3) Baixa Demanda e Alto Controle = Baixa Tensão no Trabalho: o modelo revela que, quando o nível de exigência é baixo e a autonomia é elevada (o controle do sujeito sobre seu trabalho é elevado), há baixo nível de stress;

4) Baixa Demanda e Baixo Controle = Trabalho Passivo: o modelo considera que há um declínio nas atividades, portanto pouca utilização da capacitação do sujeito, o que leva ao estado de desesperança.

Para Baker e Karasek (1999; apud LIMONGE E RODRIGUES, 2002), há vários componentes do processo de stress do trabalho, considerados como stressores: exigências de tempo (horas extras), estrutura temporal (trabalhos em turnos) e ritmo, estrutura das tarefas (baixa autonomia, subutilização das capacidades), condições físicas (riscos físicos, ergonômicos), organização do trabalho (ambigüidade de papel, conflito, competição, rivalidade), fatores extra-organizacionais (relacionados à comunidade, insegurança no emprego, preocupações com a carreira) e extra-trabalho (família, questões pessoais). Tais componentes trazem consequiências fisiológicas, psicológicas (cognitivas e afetivas) e sociais, de curto e longo prazo: fisiológicas - adrenalina, cortisol, aumento de pressão arterial (curto prazo), hipertensão, doenças coronárias, úlceras, asma (longo prazo); psicológicas - ansiedade, insatisfação (curto prazo), depressão, burnout (longo prazo); sociais - absenteísmo, improdutividade, pouca participação, abuso de fumo, álcool (curto prazo), desesperança (longo prazo).

Outro aspecto abordado pelos autores é a importância dos "moderadores", que ao intervirem na estrutura de decisão e na forma de organização do trabalho podem atuar como fatores de coping, por exercerem grande influência externa nos níveis de tensão dos sujeitos e em 
benefício deles. Os moderadores são de ordem individual (mudança no estilo de vida e recursos pessoais, auto-estima) ou de suporte social (apoio emocional, informação).

Krantz e Raisen (1988) estudaram a relação entre stress ambiental (características do ambiente ocupacional), reatividade psicofisiológica (mudanças nos níveis fisiológicos, produzidos pelos stressores ambientais) e desenvolvimento de doenças cardíacas e apontaram que essa relação depende do significado da situação atribuído pelos indivíduos e do modo como percebem as situações de sua vida, portanto está sujeita à avaliação cognitiva e ao coping realizado. Os autores referem-se ao importante estudo do modelo de demanda-controle de Karasek sobre diferentes profissões, no qual identificaram que as ocupações com excessiva demanda (elevada carga de trabalho) e baixo controle (pouca autonomia e falta de liberdade para tomar decisões) apresentaram situações de alto esforço e estavam associadas com maior nível de stress relacionado ao trabalho e com maior risco de doença coronariana.

Limonge e Rodrigues (2002) e Tamoyo (2004) descrevem outro modelo de relevância teórica, o de Cooper e outros autores (1988, 1997), que considera a existência de fatores ambientais - que envolvem vida social, familiar e no trabalho - e fatores individuais - que contemplam padrões de comportamento (tipo A e B) - como indicador de stress, que requer estratégias de coping adequado para a interrupção desse estado de stress.

As principais fontes stressoras relacionadas ao trabalho, segundo esses autores, são: estrutura e clima organizacional (estilo de liderança, nível de participação, autonomia, liberdade e tomada de decisão), fatores intrínsecos ao trabalho (ruído, iluminação, número de horas de trabalho, exposição a riscos e equipamentos de tecnologia), papel na organização (sobrecarga, excesso de responsabilidade, conflito, ambigüidade, pressão, isolamento), relacionamento (com colegas, gerentes e subordinados), desenvolvimento de carreira (insegurança no trabalho, aposentadoria, precariedade do contrato, risco de desemprego, ênfase maior em competência e habilidades, promoções, reconhecimento) e interação trabalho-família.

Para Limonge e Rodrigues (2002), algumas situações são consideradas potencialmente stressantes, tais como: situações novas - se associadas a um acontecimento anterior que gerou ameaça ou dano; incerteza do acontecimento - dúvida se determinado evento vai ocorrer ou não; iminência do acontecimento - tempo que antecede o fato (momentos próximos à avaliação de desempenho, por exemplo) ou quando o processo para tomada de decisão deve ser muito 
rápido, o tempo de avaliação é pequeno e as consequiências de cada ato podem ser importantes; ambigüidade - quando não se dispõe de informações completas sobre o que está acontecendo.

A seguir abordaremos as questões de desempenho e sua vinculação com o stress.

(1) Informação fornecida por Vasconcellos em aula expositiva na USP, na disciplina Conceitos Básicos de Stress: Teorias e Experimentação Científica no Campo da Psicologia Social I, em 2005. 
Segunda Parte - DESEMPENHO

\section{DESEMPENHO E AVALIAÇÃO}

Reiteramos que, diante de um cenário desafiador externo e interno às organizações, com alto grau de fontes stressoras, que demandam grandes esforços do indivíduo, as questões vinculadas à capacitação, atualização de competências e desempenho tomam proporção relevante para adequação ao trabalho. O desempenho dependerá do compromisso do sujeito com os objetivos do grupo ao qual pertence, mas não necessariamente conseguirá chegar ao grau de eficácia dos resultados demandados pela empresa.

Michinsky (2004) aponta a importância de diferenciar os conceitos de desempenho e eficácia. Para o autor, desempenho é o comportamento e o que as pessoas efetivamente fazem, o que pode ser observado, inclui ações que dizem respeito às metas da organização e pode ser medido pelo nível de contribuição do funcionário. A eficácia refere-se à avaliação dos resultados do desempenho e está além do controle do indivíduo, pois depende de vários fatores sobre os quais o funcionário tem pouca influência.

Para Le Boterf (2003), a experiência cotidiana mostra amplamente que múltiplos fatores, além do profissionalismo ou da competência, podem intervir na eficácia do desempenho. O estado dos equipamentos, o gerenciamento, os acasos da conjuntura são variáveis intervenientes. $\mathrm{O}$ autor aponta que alguns indicadores mais sutis podem ser identificados, como feedback dos clientes e beneficiários, prazos de encaminhamentos e outros fatores externos ao trabalho, que possibilitam o julgamento da eficácia.

É possível saber se o nível de desempenho no trabalho é satisfatório, mediante a utilização de instrumentos que permitam avaliar com razoável adequação o nível de resultados gerados pelo indivíduo. O instrumento que ao longo do tempo ganhou maior expressão é a avaliação de desempenho no trabalho. Como aponta Malvezzi (1980), um sistema de avaliação representa uma força transformadora de mudança dentro das organizações.

Hoje as empresas têm um papel social muito mais amplo do que o de oferecer empregos e remunerar as pessoas pelos serviços prestados. São co-responsáveis pela capacitação e promoção da satisfação de valores sociais básicos e estão se conscientizando de que a obtenção de resultados está diretamente relacionada a uma relação de reciprocidade com seus colaboradores e 
parceiros. A avaliação de desempenho, portanto, passa a ter caráter mais abrangente, pois aproxima as duas partes (empresa e indivíduo) e exerce papel de facilitadora nessa relação de interdependência que o contexto atual exige. É vastíssimo o número de pesquisas sobre o assunto que tratam dos esforços em definir desempenho, traçar modelos de avaliação e seus determinantes e apresentaremos algumas delas a seguir.

Para Gowler e Legge (1980), a avaliação é literalmente o acesso ao valor ou à valia, à luz de critérios específicos, que envolve um processo de formulação de um julgamento sobre a habilidade de um sujeito, com a conclusão se houve sucesso ou fracasso. Segundo as autoras, a avaliação invariavelmente tem implicações e é utilizada para determinar as escolhas que irão conduzir uma ação.

Arvey e Murphy (1998) fizeram uma ampla revisão da literatura de avaliação do desempenho no contexto do trabalho e verificaram que, de 1950 a 1980, a maioria das pesquisas direcionou-se para a melhoria dos instrumentos de desempenho e se propunha basicamente a sua classificação, pois o que se pretendia era conseguir padrões mensuráveis e mais objetivos de referência.

A fim de neutralizar os possíveis vieses da avaliação, as pesquisas desse período concentraram-se essencialmente no refinamento da parte psicométrica das ferramentas, com vistas a minimizar erros e buscar eliminar a subjetividade. Desde então esses estudos buscaram aperfeiçoamento dos instrumentos de medição, para melhorar a confiabilidade, precisão e validade das avaliações de desempenho, mas, como refere Paz (1992), esses esforços não garantiram a eficácia do processo de avaliação de desempenho, o que levou os pesquisadores a buscar novas estratégias. A literatura publicada nesse período indica que a maioria dos estudos sobre avaliação de desempenho parte da premissa de que as avaliações são tendenciosas e de que essa característica é inerente ao processo de julgamento do comportamento humano, tendo em vista ser o avaliador o grande responsável pelas dificuldades de condução do processo.

Com o objetivo de compreender o comportamento dos avaliadores, as pesquisas após os anos 80 transferiram o foco da questão instrumental para o entendimento do modo como os avaliadores constroem suas percepções e os julgamentos em relação ao desempenho dos seus subordinados.

Especialmente após a década de 90, a literatura aponta avanços nas pesquisas em avaliação de desempenho. Com a flexibilidade na mudança de papéis, as ferramentas se tornaram 
mais genéricas, o uso da avaliação se expandiu, bem como a visão sobre o desempenho no cargo, que não se volta apenas à mensuração da execução de tarefas específicas, mas envolve a dimensão de avaliar o desempenho num contexto organizacional mais amplo, com a multifuncionalidade e a generalidade.

A subjetividade dos instrumentos de avaliação não tem necessariamente o significado de viés ou erro do avaliador, como nas décadas anteriores, pois o que conta é a reflexão sobre o grau de contribuição, resultados do indivíduo e seu valor enquanto potencial e capital intelectual para a empresa. O indivíduo pode ter valor para a organização porque possui características pessoais que refletem diversidade no trabalho ou se destaca em habilidades específicas que o diferenciam dos demais.

As pesquisas se voltam para compreender o avaliador, quanto à sua motivação em avaliar, e os fatores contextuais (aspectos políticos, distorções, processos, senso de justiça e ética). Klimoski e Inks (1990) estudaram como a força do comprometimento e da responsabilidade do avaliador pode influenciar a qualidade do resultado da avaliação.

Austin e Villanova (1992) verificaram que os critérios utilizados na avaliação de desempenho têm se alterado e se expandido. Os avaliadores têm exigido comportamentos dos subordinados que vão além do papel que é requerido para o cargo, como ter responsabilidade social ou trabalhar nos finais de semana para terminar um projeto com prazo reduzido.

Folger e outros autores (1992) demonstraram que um processo adequado de avaliação precisa apresentar três características essenciais: divulgação e explicitação clara do processo e do padrão de desempenho esperado; realização da reunião de avaliação, em que o avaliado recebe retorno sobre os resultados de desempenho; isenção de julgamento por parte do avaliador, avaliação baseada em fatos e sem distorção por conta de pressões externas, corrupção ou vieses pessoais.

Martell e Borg (1993) revelaram que não há diferença entre avaliação feita em grupo e avaliação individual, quando realizada imediatamente após uma situação. Porém, se a avaliação de uma situação for feita depois de um período de intervalo de cinco dias, a avaliação em grupo se revela mais precisa.

McCloy, Campbell e outros autores (1994) definiram desempenho como comportamento ou ações em face de metas organizacionais e propuseram uma estrutura multidimensional para investigar o desempenho, incluindo no modelo, determinantes gerais (mensuráveis) e 
determinantes específicas de avaliação de desempenho (motivação, habilidades, conhecimento, experiência).

Outro aspecto em evidência em pesquisas recentes tem sido investigar quais são os fatores de avaliação de desempenho voltados especificamente às habilidades técnicas do cargo e quais os fatores voltados para o contexto organizacional. O primeiro item avalia o desempenho técnico funcional; o segundo avalia o nível de contribuição do empregado no âmbito do ambiente social e psicológico e o alcance das metas organizacionais. Fatores como entusiasmo, persistência e esforço adicional são facilitadores da comunicação, estimulam o trabalho em equipe e são redutores de tensão do ambiente.

Os resultados demonstrados por Motowidlo e Van Scotter (1994) apontam que tanto os fatores técnicos quanto os organizacionais contribuem para o desempenho, no entanto os fatores comportamentais correlacionam-se em grau muito maior com o desempenho contextual e estão de acordo com as expectativas organizacionais.

Woehr (1994) constatou que há diferença significativa nos resultados das avaliações quando os avaliadores são treinados. Eles revelam que os treinamentos modificam e influenciam diretamente nos referenciais dos avaliadores, na medida em que os capacitam com informações substanciais para adequar conceitos e processos.

O’Driscoll e Beehr (1994) concluíram que supervisores têm um papel fundamental, pois podem influenciar diretamente no nível de desempenho, stress e incerteza de seus subordinados, que por sua vez vai interferir no grau de insatisfação, tensão e intenção de desligamento.

Hedge e Borman (1995) afirmaram que diferentes avaliadores têm melhores condições de perceber e captar diferentes ângulos ao medir desempenho (gestores, pares, subordinados) e que sistemas informatizados podem ser úteis para monitorar a avaliação como um todo.

Bommer e Johnson (1995) discutiram as diferenças entre as medidas de desempenho relativamente objetivas e as subjetivas e concluíram que há subjetividade também nas escolhas das medidas objetivas que envolvem as métricas.

Mero e Motowidlo (1995) demonstraram que avaliadores são mais precisos em realizar avaliações quando são responsáveis e precisam justificá-las.

Viswesvaran e outros autores (1996) investigaram a análise de confiabilidade das classificações de desempenho, considerando diferentes avaliadores, avaliação da chefia e autoavaliação do empregado. Evidenciaram que o uso da auto-avaliação permite a correção de erros 
nas medidas de avaliação, que a mensuração das competências interpessoais tem menor confiabilidade do que as medidas de produtividade ou qualidade e que as tarefas técnicas são avaliadas com maior confiabilidade do que os fatores que envolvem variáveis comportamentais.

Varma e outros autores (1996) estudaram a precisão das classificações de desempenho e o nível de relacionamento interpessoal entre avaliador e avaliado e identificaram que a relação próxima ou não entre avaliador e subordinado pode interferir nos resultados de desempenho.

Consideramos nesta pesquisa o conceito de DUTRA (2002), que define avaliação de desempenho como "um conjunto de entregas e de resultados de uma determinada pessoa para a empresa ou negócio", que divide em três dimensões interdependentes: o desenvolvimento (dimensão mais importante e associada à capacidade do sujeito de lidar com situações complexas), o esforço (inerente à automotivação e às condições oferecidas pela empresa) e o comportamento (comparado com o padrão de conduta definido pela empresa).

$\mathrm{O}$ autor acredita que a avaliação de desempenho com base no desenvolvimento deva ser realizada pelo próprio sujeito e por sua chefia imediata, com acompanhamento da chefia mediata (dois níveis acima). Para atender a esse objetivo, é realizada a análise das competências, que constam da formação, experiência e conhecimento, direcionada para os resultados ou níveis de entregas. A comparação dos resultados indica o quanto o sujeito precisa se desenvolver, qual o seu espaço ocupacional atual e projeção de carreira. Os níveis de desempenho e de desenvolvimento permitem traçar planos de ação individuais, com vistas a potencializar os pontos fortes e aprimorar os pontos a desenvolver.

Com relação à situação dos jornalistas, são poucas as empresas que avaliam o desempenho por meio de um instrumento formal. $\mathrm{O}$ alicerce da avaliação de desempenho têm sido os resultados medidos com base na repercussão da matéria e seus desdobramentos, na audiência do telejornal e na imagem do repórter junto ao público. O sujeito é assim avaliado por agregar valor à organização, porque possui competências técnicas e individuais que se destacam nos resultados e o diferenciam dos demais. Esses resultados são avaliados também pelos prêmios que recebem.

Por outro lado, embora as empresas de televisão possibilitem desafios diários e oportunidades para o desenvolvimento dos jornalistas, os gestores não têm práticas definidas de avaliar o desempenho com regularidade e raramente estabelecem planos de ação individual para a melhoria dos níveis de competências e do desempenho, o que gera grande carência de feedback 
e profissionais queixosos por não terem clareza quanto ao padrão esperado pela empresa ou por não terem visibilidade de carreira.

Conforme refere Dutra (2002), o profissional não precisa ser promovido para agregar mais valor à organização, pois ele pode assumir mais responsabilidades, novos desafios, atribuições mais complexas e expandir o espaço do seu cargo, no entanto ele precisa ser estimulado e norteado no seu autodesenvolvimento para que possa autogerenciar suas possibilidades de crescimento.

\section{COMPETÊNCIA}

Conforme já relatado, o paradigma emergente de gestão de empresas valoriza o perfil do telejornalista com uma ampla gama de habilidades e características fortemente empreendedoras, autônomas, realizadoras, colaboradoras e criativas, engajados à cultura e valores organizacionais. Com base nesse posicionamento, os telejornalistas mais talentosos, que são os profissionais que apresentam habilidades técnicas e compatibilidade com padrão de bom desempenho definido pela empresa, esperam diferenciar-se nas suas participações no trabalho, na medida em que buscam como meta o enfrentamento de desafios cada vez mais importantes para si e para a empresa.

Analisar o nível de competência do telejornalista é fundamental para que este desenvolva o autoconhecimento sobre suas potencialidades de ação e pontos de melhoria. O termo habilidade é outro conceito amplo e, segundo Attewell (1990), evoca idéia de expertise, maestria, excelência. No núcleo dessa definição está a idéia de competência ou proficiência, que é a capacidade de realizar algo bem.

O conceito de competência passou a ser estudado mais intensamente na literatura acadêmica a partir dos anos 80, quando predominava apenas a noção de qualificação, que remete à especificidade do indivíduo em termos de diplomas de formação e lhe confere o direito de exercício de uma profissão, um emprego ou uma função. Conforme Le Boterf (2003), a qualificação é uma habilitação e resulta de negociações que levam à convenção coletiva e a sistemas de classificação. Ela é necessária, mas que não significa que os atributos serão utilizados com competência. 
Por outro lado, a noção de competência remete às exigências e aos discursos da contemporaneidade e traduz as novas formas de organização do trabalho e menor clareza na definição dos cargos, o que reflete nos processos de recrutar, selecionar, desenvolver e avaliar o desempenho dos profissionais. A maior flexibilidade e amplitude dos cargos pressupõem um abandono das descrições voltadas para tarefas específicas, que possibilitavam maior controle, como no paradigma tradicional de gestão de empresas; em contrapartida, prevê a utilização de competências mais genéricas, que permitem aos sujeitos maior expansão na atuação.

O termo competência tem sido utilizado por diferentes autores, com diversos sentidos, para a mensuração do desempenho organizacional e individual. Descreveremos três diferentes visões de competência: a abordagem estratégica, a comportamental e a integrada (SAMPAIO, 2002).

A abordagem estratégica é oriunda da área de Marketing e a definição mais difundida é a de Prahalad e Hamel, que a sintetiza como a capacidade de combinar, misturar e integrar recursos em produtos e serviços. A idéia de competência é corporativa, em que se definem as competências essenciais da organização e as competências funcionais (atividades-chave de cada área), tendo em vista a gestão da organização como um todo, os objetivos do negócio em relação ao posicionamento no mercado e as estratégias que vão determinar o alinhamento das políticas e práticas de gestão de pessoas.

A abordagem comportamental trata das competências individuais e foi desenvolvida por McClelland, Boyatzis e Spencer \& Spencer. Ela é definida como um conjunto de conhecimentos, habilidades e comportamentos que uma pessoa detém e que vai possibilitar desempenho superior no trabalho (SPENCER \& SPENCER, 1993). Por tratar-se de uma definição que abrange as potencialidades de que o indivíduo dispõe, posteriormente os autores diferenciaram soft competencies (traços de personalidade, valores) e hard competencies (habilidades técnicas) (SAMPAIO, 2002). Na elaboração do presente instrumento de avaliação de desempenho de telejornalistas, não foram considerados itens que avaliavam a personalidade dos sujeitos ou habilidades técnicas isoladas.

A abordagem integrada serviu de base teórica e fundamentou a elaboração do instrumento de avaliação de desempenho utilizado nesta pesquisa. Na abordagem integrada, a definição de competência associa o conceito de ação e visão estratégica (Le Boterf, 2003) à idéia de que a competência deve agregar valor ao indivíduo e à organização (Dutra, 2002). Por 
exemplo, o telejornalista utiliza suas potencialidades no trabalho a partir do saber fazer, saber agir e saber mobilizar suas capacidades sobre um contexto em que atua.

A medida efetiva de seu desempenho é conhecer o quanto consegue trazer de resultados para a empresa, dentro do esperado, e o instrumento de avaliação de desempenho elaborado nesta pesquisa levou em conta as competências direcionadas para o saber fazer, o saber agir (formação acadêmica, experiência e conhecimentos técnicos) e a mensuração dos respectivos níveis de resultados. Temos a avaliação da realização de atividades de pré-reportagem, mensuração de diferentes maneiras de expressar-se no vídeo, de preparar-se para o enfrentamento das situações etc.

Le Boterf (2003) ampliou o sentido de competência individual e referiu-se à competência não como um conceito estável ou de definição precisa dos seus atributos, mas como um conceito que se transforma a partir da inter-relação de três campos: o da biografia (processo de socialização constante do indivíduo), o da experiência profissional e o da formação educacional. Nesse conceito, a competência é produzida em função da convergência das características de uma situação e da representação que o sujeito constrói (pensamento e avaliação) daquela vivência. É saber agir, mobilizar, comunicar, aprender, assumir responsabilidade e ter visão estratégica.

Wittorski (2004) amplia o conceito, entendendo que a competência envolve a combinação de cinco componentes: cognitivo (o saber, os conhecimentos adquiridos pela formação, a construção ativa do sentido da situação), cultural (influência da cultura organizacional), afetivo (a auto-imagem, prazer no que faz, engajamento e motivação), social (reconhecimento do meio ou da organização) e prático (avaliação de desempenho, atribuição de valor). Essa combinação se articula em três níveis: micro (indivíduo), meio social imediato (coletivo do trabalho, organização) e macro (sociedade). Para o autor, a competência corresponde "à mobilização na ação de certo número de saberes, combinado de maneira específica em razão do quadro de percepção que o ator constrói da situação".

Le Boterf (2003) estudou três tipos de profissões: as que têm dominância da dimensão da competência (engenheiro, enfermeiro), as com dominância do talento (ator, músico, poeta) e as profissões "mistas" (jornalista, arquiteto, compositor). A profissão do telejornalista tem característica de profissão "mista" porque é avaliada por um produto específico (por exemplo, uma matéria do repórter ou a imagem do repórter cinematográfico) cujo resultado precisa ser 
marcado pelo talento pessoal (estilo do entrevistador, imagem surpreendente) e pela é competência profissional. Segundo o autor, isso explica muitas dificuldades e resistências encontradas nos procedimentos para avaliar competências de profissões como a de jornalista, caracterizadas como "nobres". Le Boterf afirma que se justifica criar comitês de avaliação em que há vários juízes que formam um grupo profissional, com julgamentos confrontados, para minimizar os efeitos de avaliações isoladas.

Para empregar o conceito de competência com vista à agregação de valor, Dutra (2001, 2002, 2004) conceitua competência associada à mensuração da capacidade de entrega (resultados) do indivíduo. Parte da premissa de que as pessoas são valorizadas pelos seus atos e realizações, tendo em vista o que a empresa espera e necessita. A entrega relaciona-se a uma ação responsável do indivíduo que agrega valor à empresa, a si mesmo ou à sociedade. Ele também refere que "as competências tendem as ser caracterizadas como a contribuição das pessoas para a capacidade da empresa de interagir com seu ambiente, ampliando suas vantagens competitivas".

$\mathrm{O}$ autor pesquisou diferentes carreiras praticadas no mercado e dividiu-as em três categorias: operacionais, profissionais e gerenciais. A carreira de jornalista (repórter e repórter cinematográfico) se enquadra na especificação de carreira profissional e está ligada a atividades que exigem formação técnica ou superior, funções especializadas, sem responsabilidade pela gestão de pessoas. Para que esses profissionais possam assumir suas funções, precisam dispor de significativa vivência profissional, que na prática se traduz em elevada contribuição para o telejornal em que atua e conseqüentemente para os resultados da empresa. 
Embora haja inúmeras pesquisas que investigam a relação entre stress e desempenho, ainda existem controvérsias sobre se a correlação é mais bem caracterizada pela teoria linear negativa, pela teoria linear positiva ou se há uma correlação como um U-invertido.

A teoria linear negativa é baseada na premissa de que o stress prejudica o desempenho, pois consome energia, diminui a percepção e a atenção do sujeito, leva-o a ignorar informações importantes e desencadeia respostas fisiológicas involuntárias que interferem no desempenho.

Na direção oposta está a teoria linear positiva, baseada na hipótese de que o stress e a ansiedade geram desafios, que em contrapartida melhoram o desempenho do indivíduo, e de que baixos níveis de stress não levam a desafios e conseqüentemente o desempenho é fraco (MUSE, HARRIS \& FEILD, 2003).

A teoria do U-invertido representa uma combinação da teorias lineares negativa e positiva, cujos estudos pioneiros se iniciaram com Yerkes e Dodson em 1908 (BENSON, 2005), e sustenta que algum stress é necessário para alcançar o nível ótimo de desempenho e que níveis de stress abaixo ou acima do nível ótimo são prejudiciais ao desempenho. A teoria pode ser observada em um gráfico, ou seja, na extremidade inferior da escala (eixo x, stress e eixo y, desempenho), à medida que o nível de stress aumenta, o desempenho do indivíduo tende a aumentar.

No ponto intermediário da escala, há um nível ótimo de stress e desempenho, em que o stress é moderado e o desempenho está no pico. A partir do momento em que os estímulos de stress são bastante altos, há uma mudança na direção da escala e o desempenho tende a cair, isso porque o indivíduo fica sobrecarregado e não consegue responder a mais estímulos (MUSE, HARRIS \& FEILD, 2003).

Embora pesquisadores sejam favoráveis à teoria do U-invertido, os achados empíricos têm demonstrado maior evidência na relação da teoria linear negativa, o que levou alguns estudiosos a abandonar e a criticar fortemente a teoria do U-invertido, como é o caso das pesquisadoras Westman e Eden (1996), que estudaram várias medidas de desempenho e correlacionaram-nas ao nível de stress, evidenciando que o desempenho é substancialmente menor quando há elevado nível de stress, pois demandas excessivas têm efeitos negativos sobre o desempenho, não confirmando a hipótese do U-Invertido. 
Lazarus (1974) constatou que o stress pode mobilizar o indivíduo para o desempenho mais eficaz das tarefas, porém impede a resolução de conflitos. Aspectos afetivos como angústia e depressão interferem no pensamento e na capacidade de solução de problemas, podendo reduzir o grau de eficácia para dominar uma situação. A exposição da pessoa a situações stressoras diminui seu campo perceptual, tornando-a menos consciente das características do ambiente e menos apta a utilizar informações relevantes.

Cohen (1980) revelou que, embora o ser humano se adapte a condições de extremo stress, há um custo cumulativo, cuja hipótese foi estudada por Selye (1956) e observou que, após um período prolongado de exposição a agentes stressores, as reservas adaptativas do indivíduo diminuem, bem como seu nível de resistência, e o nível de exaustão se estabelece.

O pesquisador revisou a literatura sobre os estudos dos efeitos do stress no desempenho e indicou que as pessoas desempenham com menor eficiência tarefas que requerem tolerância à frustração, baixa distração, precisão e percepção mais acurada e que os efeitos advêm de uma ampla relação de stressores imprevisíveis e sem controle, como barulho, frio, burocracia, discriminação, densidade espacial e sobrecarga de trabalho. Cohen revelou que as pessoas sob stress ficam menos sensíveis aos outros, diminuem a prontidão para colaborar e para reconhecer diferenças individuais e aumentam seu nível de agressividade. Ele demonstrou que, quanto maior o controle pessoal e maior a previsibilidade do stressor, mais eficazes serão as possibilidades de redução dos efeitos pós-stressores.

Motowidlo, Packard e Manning (1986) examinaram as implicações negativas do stress e os padrões de co-variação nos efeitos no desempenho profissional. A pesquisa revelou que o stress leva a estados emocionais de ansiedade, hostilidade e depressão, que são causados por situações do trabalho e prejudicam o desempenho. Os autores afirmam que, quanto maior for a freqüência e a intensidade dos eventos stressores, mais o indivíduo será afetado. As condições do cargo (por exemplo, trabalho externo) e as características do funcionário, como experiência, padrão de comportamento do tipo A e medo de receber avaliação negativa do ambiente, são vistas como determinantes dessa relação.

Os autores enfatizaram que agentes stressores são mais freqüentes em algumas profissões/ funções, como a de jornalista, em que os ambientes são agitados e cheios de múltiplas atividades, emergências, factuais e deadline (1) e em que as pessoas, para apresentarem bom 
desempenho, precisam ser eficazes nas competências e habilidades interpessoais, motivacionais e cognitivas.

Weimberg (1990) revisou a literatura que relaciona ansiedade e desempenho e a teoria do U-Invertido. Sua pesquisa enfatizou que a relação entre estímulo e desempenho é mais complexa do que a teoria do U-Invertido propõe, dada a amplitude das tarefas e as diferenças individuais entre as pessoas, para mensurar níveis de ansiedade (alto, médio e baixo). Segundo o autor, os estímulos stressores afetam de diferentes formas as pessoas, que respondem com diferentes níveis de ansiedade, e é necessário primeiro determinar o nível ideal de ansiedade dos sujeitos, para então mensurar o desempenho e em seguida comprovar ou não a hipótese do U-Invertido.

Já os estudiosos Muse, Harris e Feild (2003), não satisfeitos com a controvérsia dos resultados da relação entre stress e desempenho, realizaram revisão das pesquisas entre os anos de 1975 e 2000 e consideraram 52 estudos para uma análise detalhada, sobretudo a fim de testar algum viés na teoria do U-invertido. Desse universo, 46\% (24 pesquisas) concluíam pela correlação negativa, ou seja, níveis aumentados de stress geram aumentos prejudiciais de desempenho; 13\% (7) se apoiavam na correlação positiva, ou seja, o stress representa um desafio que melhora o desempenho; $4 \%$ (2) fundamentaram-se na teoria do U-invertido; $25 \%$ (13) revelaram resultados mistos e $12 \%$ (6) não obtiveram correlação entre stress e desempenho. Os estudiosos concluíram que a maioria das pesquisas não oferecia um teste exato para analisar a teoria do U-invertido e que há vieses nos resultados que não permitem concluir sobre as correlações acima.

Limonge e Rodrigues (2002) referem que as pressões sobre as pessoas precisam ser moderadas para que o desempenho seja eficiente e que, quando a tarefa é muito intensa ou é pacata e sonolenta, o resultado é um desempenho insuficiente.

Siu (2003) encontrou correlação positiva entre compromisso com a organização e desempenho no trabalho. Seus estudos com chineses revelaram que o compromisso com a organização (valores, crenças) são moderadores significantes das relações entre stress e desempenho apenas quando o stress é baixo ou moderado. Os resultados indicaram que o indivíduo que tem compromisso com a organização tem menor probabilidade de sofrer impacto dos efeitos negativos dos stressores, quando o stress é baixo ou moderado, pois o compromisso (valores e crenças) equilibra positivamente a relação entre stress e desempenho no trabalho. Porém se constatou que, se o nível de stress é muito elevado, mesmo os sujeitos com alto nível 
de compromisso com a organização manifestam baixo desempenho. O autor enfatiza a necessidade de alterar as condições do ambiente de trabalho para a redução dos stressores e melhora do desempenho.

Benson (2005) confirma, em seus estudos, que o stress é intrínseco ao trabalho e é um fator crucial do desempenho: há necessidade de certa dose dele para obter resultados. $\mathrm{O}$ autor se baseia na "lei Yerkes-Dodson" e exemplifica que o stress é uma resposta vital em meios altamente competitivos. Antes de uma reunião importante ou, se pensarmos na nossa pesquisa, antes de enfrentar o jornal no "ar" no caso dos jornalistas, o indivíduo entra num pico de atividade, seus batimentos cardíacos aumentam, bem como a pressão arterial, e dessa forma ele fica mais focado, alerta e eficiente, até atingir o topo da curva de Yerkes-Dodson. Mas, ultrapassado certo nível, o stress acaba comprometendo o desempenho e a eficiência, pois o indivíduo começa a sentir os efeitos do excesso de demanda sobre o organismo e pode ser invadido por sensações de distress, como ansiedade, temor, tédio.

$\mathrm{O}$ autor elaborou a teoria do princípio da ruptura, que se baseia na necessidade de usar a reposta do relaxamento em seguida ao pico da curva do stress, para neutralizar os efeitos negativos dos hormônios do cortisol e da epinefrina e permitir que o cérebro se acalme e produza o óxido nítrico, que faz o indivíduo se sentir rapidamente mais produtivo. Quando esse fenômeno, chamado "calma comoção", ocorre, a produção de neurotransmissores, como endorfinas e dopaminas, acentua a sensação de bem-estar, o que favorece a atenção, o foco nos conceitos de tempo e espaço, a tomada de decisão e principalmente a criatividade, sendo possível estimular o desempenho neurológico muito superior ao que se conseguiria sem esse exercício.

Hallowell (2005) relatou estudos em que o cérebro, quando sobrecarregado pelo processamento demasiado de informações, reage ao ambiente hipercinético com menor capacidade de solucionar problemas com flexibilidade e criatividade. Os estudos referem que o stress do ambiente de trabalho pode alterar a fisiologia cerebral e desencadear o fenômeno neurológico do "traço de déficit de atenção", cujos sintomas interferem diretamente no desempenho, levando à distração, agitação interna e impaciência, que redundam em falta de concentração, dificuldade de raciocinar com clareza, de organizar-se e de administrar o tempo.

(1) deadline: prazo para o repórter enviar para a redação fitas com imagens, entrevistas e texto feitos na rua. 


\section{TELEJORNALISMO - NATUREZA DA TAREFA}

Historicamente, foi somente quando a moderna imprensa americana começou a emergir e a competir com a televisão, nos anos de 1950, que se passou a contratar graduados em jornalismo no meio televisivo, para fazer frente às exigências de maior competitividade e introdução de novas tecnologias, que visavam à maior lucratividade das empresas de comunicação nos Estados Unidos.

No Brasil, a televisão também teve grande impulso após os anos 50, dado por Assis Chateaubriant, fundador da TV Tupi, em São Paulo. Como não havia especialistas para trabalhar em televisão no Brasil, profissionais de várias áreas afins migraram do cinema, rádio, jornal e propaganda para essa nova atividade. Na década de 60, outras emissoras, como a Globo, a Record, a Excelsior e a Bandeirantes, receberam concessão do governo militar para atuarem e buscaram qualificar seus profissionais dentro das próprias empresas, até que mais tarde os jornalistas graduados fossem incorporados aos quadros de pessoal.

A televisão é um veículo de comunicação pluralista, que possibilita a valorização da cultura de um povo e que, sobretudo por meio dos noticiários, fala de questões sociais do interesse do público brasileiro.

Wolton (2006) estudou a televisão aberta brasileira e mundial e considera que é o mais democrático dos veículos de comunicação, não apenas por sua grande área de abrangência ou por ser gratuita, mas por ser acessível a diferentes níveis sociais, econômicos e culturais do país, sendo portanto um dos maiores meios de massa e símbolos do coletivo. Segundo o autor, a televisão está mais próxima de ter um papel de indústria cultural, que contribui para a identidade nacional, modernização e integração social, do que um papel de controle político. Pra ele, a televisão "é vista como uma mídia generalista, de importância social, criada para todos os públicos, que assume o papel de laço social numa sociedade de solidões organizadas".

Segundo Anderson (2006), o negócio televisão tem sofrido intensas transformações com a expansão da concorrência, as mudanças de hábitos do consumidor, o avanço tecnológico, a convergência de mídias e o crescimento da cauda longa da internet, que dispersa o mercado de massa para o mercado de nicho e que tem impacto sobre os processos de trabalho. No 
telejornalismo, grandes mudanças tecnológicas têm permitido levar a imagem ao telespectador com mais qualidade e o trabalho tem demandado um fazer mais e mais rápido dos profissionais.

O objetivo dos telejornalistas é informar com precisão e eles consideram que a notícia tem relevância a partir do momento que atinge um grande número de pessoas e tem reflexo na vida das comunidades. Essa constatação tem relevância comercial, uma vez que atingir o mercado de massa implica ter audiência, o que está atrelado à venda do espaço publicitário ou do merchandising e a um bom retorno econômico para a empresa. Mas do ponto de vista jornalístico isso também é importante, uma vez que a clareza da linguagem levará a informação a um maior número de pessoas, independentemente do grau de escolaridade ou do local onde estiverem.

De modo genérico, os telejornalistas (repórteres e repórteres cinematográficos) são divididos conforme a natureza das tarefas que realizam: são os diaristas e os especiais. Os diaristas fazem matérias curtas, rápidas e coberturas do que acontece no dia-a-dia (essas matérias são chamadas também de factuais: um buraco de rua que provoca trânsito, chuvas que acarretam enchentes, acidentes nas estradas, informações de utilidade pública, novas medidas econômicas etc.). Aqui o imediatismo conta pontos, a notícia em primeira mão é "furo de reportagem" e há uma eterna corrida contra o limite de tempo, entre a edição final da matéria e o fechamento do telejornal (deadline), em que a velocidade não pode comprometer a qualidade.

Os telejornalistas especiais geralmente são os mais experientes e mais especializados em assuntos como economia, política ou meio ambiente. Também são os que fazem reportagens mais longas e matérias mais elaboradas, minidocumentários que requerem pesquisas (matérias investigativas, entrevistas com vários personagens) e muitas vezes deslocamento de uma equipe de profissionais, por várias semanas, para outros estados ou para o exterior.

Para Bistane e Bacellar (2005), fazer reportagens especiais é quase um privilégio, porque há mais tempo para elaboração, produção e edição. No caso do jornalismo especial, a pressão imediata de tempo é menor, porém há dificuldades quanto aos imprevistos, barreiras culturais e lingüísticas se a cobertura for em outro país, além do elevado nível de exigência quanto à qualidade das imagens e ao resultado esperado diante do investimento feito. Nesse sentido, a natureza da tarefa de telejornalismo, seja o profissional diarista ou especial, é estimuladora e desafiadora, porém repleta de agentes stressores e propiciadora do desenvolvimento de sintomas de stress. 


\section{DESCRIÇÃO DE CARGO}

A fim de aprofundar a explicação sobre a natureza das tarefas do telejornalista (repórter e repórter cinematográfico), fizemos a descrição dos cargos, que serviu de base para a elaboração das planilhas de avaliação de desempenho, instrumentos que serão abordados mais adiante.

A descrição de cargo é um detalhamento das responsabilidades e atividades inerentes à função, ou seja, um conjunto de tarefas que se espera que o telejornalista seja capaz de realizar.

\subsection{Repórter}

É uma função especializada, de natureza técnica, ou seja, não há responsabilidade pela gestão de pessoas ou recursos (materiais e orçamentários), porém a função se diferencia pelo nível de complexidade das matérias e pelos desafios propostos aos profissionais.

Requisitos do cargo: Para o cargo de repórter exige-se formação superior em Comunicação Social, com habilitação em Jornalismo. Para que o profissional possa assumir suas funções em televisão, além da graduação específica, precisa ter habilidades e competências técnicas, vivências e conhecimentos que na prática se traduzem pelo adequado nível de contribuição para o telejornal ou programa jornalístico em que atua.

Experiência: A experiência é muito importante e é requerida prática profissional na realização de matérias jornalísticas, bem como o domínio da linguagem técnica de televisão, que envolve conhecimentos como: domínio da língua portuguesa, técnica de expressão no vídeo, contato com fontes jornalísticas, prática em produção de reportagem e edição, uso adequado de tecnologia (informática e edição não-linear) e conhecimento do idioma inglês.

Descrição sumária: O repórter acompanha pessoalmente acontecimentos políticos, sociais, esportivos, artísticos e religiosos, bem como planeja, organiza e busca notícias ou informações sobre assuntos predeterminados, realizando entrevistas e reportagens e selecionando-as para veiculação em televisão, no instante e local em que ocorram ou posteriormente.

Descrição detalhada: O repórter de telejornalismo planeja, pauta, apura e pesquisa informações previamente a fim de preparar-se para as coberturas ou reportagens, buscando qualidade e profundidade da matéria. Participa de reuniões, oferece ou toma conhecimento da matéria do dia. Realiza contatos com fontes que possam agregar informações importantes, 
colaborando com o trabalho da produção e da edição de reportagem. Trabalha incessantemente na busca de novas pautas de notícias e está permanentemente atento para recolher e redigir informações "quentes" sobre assuntos de interesse público, como eventos que acabaram de acontecer (factuais), acidentes, crimes, investigações, atos públicos, acontecimentos esportivos etc. Desloca-se geograficamente para fazer entrevistas, noticiando os fatos de modo a elucidá-los ao público, e enfrenta muitas vezes dificuldades de acesso ao local, depara-se com catástrofes e corre risco de enfrentar situações de perigo e tensão, como em coberturas de guerras, como ao adentrar lugares com alto grau de violência, ao descobrir falcatruas de políticos corruptos etc. Orienta o repórter cinematográfico nas gravações das reportagens, indicando ou sugerindo ângulos que possam representar maior interesse para o público ou para assegurar maior documentação do evento. Elabora textos sobre as matérias adequando-os às imagens, de forma objetiva e dentro de curtos prazos de entrega, buscando atender aos padrões linguíísticos e editoriais definidos pela empresa. Transmite a notícia para o telejornal, fazendo entradas ao vivo, expondo sua imagem e credibilidade. Monitora o tempo de duração da matéria, preocupado em não exceder a previsão da grade de programação do telejornal. Revela autonomia na elaboração das matérias, com tomada de decisão dentro do escopo de responsabilidade da função.

Condições de trabalho: Desloca-se ao local indicado utilizando-se de meios de transporte disponíveis e nesse ambiente faz uso do microfone e posicionamento de câmeras. O computador é seu instrumento de trabalho tanto em campo quanto em ambiente fechado e na redação também se utiliza dos recursos do centro de documentação e das ilhas de edição, local onde a edição das matérias é realizada. Costuma desenvolver as atividades em horários flexíveis (manhã, tarde, noite), podendo trabalhar também à distância, quando requisitado a fazer coberturas especiais e viagens.

\subsection{Repórter Cinematográfico}

É uma função especializada, também de natureza técnica, em que o ocupante do cargo precisa ter um conjunto de destacadas habilidades e competências técnicas.

Requisitos do cargo: Para o cargo de repórter cinematográfico exige-se escolaridade de nível médio ( $2^{\circ}$ grau completo) e apresentação de registro profissional na DRT. Na emissora em que foi realizada esta pesquisa, o requisito "formação superior completa em Jornalismo" é valorizado e considerado como muito importante para o perfil da função, sendo inclusive um dos 
itens contemplados no instrumento de avaliação de desempenho. Há outros conhecimentos complementares, como o domínio do kit correspondente ${ }_{(5)}$ e do idioma inglês falado.

Experiência: A experiência nesse cargo também é muito importante, especialmente a prática na captação de imagens de assuntos de interesse jornalístico e os conhecimentos do uso da câmera, técnicas de iluminação, enquadramento, planos, fotografia, narrativa visual e edição de imagem.

Descrição sumária: O profissional vai a campo captar e registrar imagens e fatos de interesse jornalístico.

Descrição detalhada: O repórter cinematográfico de telejornalismo participa de reuniões de pauta, a fim de sugerir idéias novas que possam se agregar ao trabalho do telejornal. Toma conhecimento prévio sobre as matérias a realizar no dia, analisa as características e finalidades e planeja seu trabalho e a gravação de imagens compatíveis com as coberturas ou reportagens. Também realiza contatos com fontes que possam agregar informações importantes, colaborando com o trabalho da produção e da edição de imagem. Opera a câmera segundo as orientações técnicas, ajustando o enquadramento, a iluminação e níveis de cor, buscando manter o equilíbrio na composição da imagem. Orienta outros profissionais ligados à preparação da gravação, iluminação, funcionamento da câmera e de outros equipamentos, para assegurar a qualidade da imagem no local.

Capta imagens relacionadas a uma ampla diversidade de assuntos, movimentando a câmera segundo a situação, o entrevistado ou o tema em foco, para transmitir eventos esportivos, fatos dramáticos ou outros acontecimentos. Registra imagens, indicando ângulos que possam representar maior interesse para o público, colaborando com o trabalho do repórter. Trabalha com agilidade e dentro dos prazos de entrega, atendendo aos padrões editoriais. Revela autonomia para gravar imagens de "furos de reportagem", noticiando os fatos de modo a agregar e assegurar documentação sobre os assuntos.

Condições de trabalho: Faz uso de câmera portátil, refletor de luz, filtros de lentes e outros equipamentos necessários ao desenvolvimento do trabalho. Desloca-se ao local indicado, pois geralmente a atividade é em campo, fora da emissora, usando os meios de transporte disponíveis. Os horários de trabalho são flexíveis (manhã, tarde, noite) e ele pode trabalhar também à distância, quando requisitado a fazer coberturas especiais e viagens, quando poderá usar o kit correspondente. 


\section{PERFIL DO TELEJORNALISTA}

O profissional de telejornalismo precisa dispor de um conjunto amplo de conhecimentos e habilidades, que serão aplicados no dia-a-dia do trabalho, para ter bom desempenho.

A fim de apresentar informações mais próximas da realidade profissional, será mostrado a seguir o relato de um repórter sobre sua profissão, que nos ajudou a construir o perfil do telejornalista. Esse repórter possui vinte anos de experiência na profissão, trabalha muitos anos na empresa pesquisada e hoje atua ora como telejornalista diarista, ora como especial, também foi correspondente internacional da emissora, e é muito respeitado como bom telejornalista. Seu depoimento demonstra comprometimento afetivo e engajamento total com a profissão..

“O repórter precisa estar constantemente atualizado, escutar rádio, acompanhar fontes, ler jornal. Tem que ter raciocínio rápido, estar antenado o tempo todo, bem informado e preparado para as entrevistas. Se conhecer o arsenal tecnológico, tiver conhecimento da câmera, do computador, da edição digital, tanto melhor. Ser repórter é enfrentar obstáculos, é o prazer de ver no ar sua matéria e beneficiar pessoas no dia-a-dia. Apesar de todo o esforço para colocar a matéria no ar, nem sempre se consegue, por dificuldades de exibição ou problemas técnicos. A câmera intimida, a luz e o microfone também. Tem que se trabalhar com todas essas variáveis. $\mathrm{O}$ cinegrafista é o cara, é aquele que está ligado, antenado, a todos os estímulos externos e tem a sensibilidade para os fatos instantâneos. Imagine o repórter cinematográfico das Torres Gêmeas... A sorte persegue quem tem engajamento profissional total na função, é mesmo... a sorte converge para o indivíduo. A satisfação de ver sua matéria fazer a diferença para as pessoas, como situações de extrema pobreza, e as pessoas sendo impactadas e você ajudando a provocar mudanças para que a sociedade siga um caminho mais justo... Desvendar a corrupção... Estar com os olhos e ouvidos abertos, os olhos da câmera são os mais importantes em televisão”.

(5) Kit correspondente: expressão usada para designar o conjunto de equipamentos (computador e software de edição de imagem) utilizado nas transmissões para agilizar o envio de matérias, principalmente em viagens ao exterior. 
"O profissional tem que saber lidar com essa engrenagem. Televisão é uma fábrica de malucos, tudo em prol desse negócio e tudo centrado para mostrar a notícia, passar por cima de tantos obstáculos... E as pessoas se transformam, dada a tensão. Televisão é um caldeirão, é o momento maior de jornalismo explícito. Ser telejornalista é ter uma profissão emocionante e estimulante. Todo o processo da matéria leva à satisfação. Correspondentes internacionais captam e gravam imagens sozinhos e o trabalho em equipe faz falta. A fama instantânea da televisão faz o profissional decolar, obriga-o a ter bom senso o tempo todo, mas o próprio veículo te engole. Quero dizer que o profissional tem que saber lidar com o glamour. Nosso país idolatra exageradamente o jornalista, que é confundido com o artista de TV. Isso faz massagem no ego, são milhões de pessoas vendo sua matéria no telejornal. É um canhão muito poderoso, que pode te levar ao sucesso ou ao fracasso. É um veículo maniqueísta e tem essas facetas todas. A televisão é um processo de psicanálise de longo prazo: quando você se inflama demais, no dia seguinte toma uma cacetada. Há dias em que o jornalista se deleita no sucesso, mas no dia seguinte vem o fracasso. Se o profissional se embeber demais, é engolido, pois o sucesso é volátil, como é volátil o momento histórico que o ser humano vive. O profissional tem que se preocupar com a sensatez, o acento, as frases, esse é o lado mais elástico, além de checar informações. A televisão exige muito mais do que os outros veículos, dá trabalho, tem que sair à rua, ir para onde a notícia está. O profissional tem que gostar da profissão acima de tudo."

\subsection{Perfil do repórter}

A partir do relato acima, podemos dizer que o desafio diário do repórter de televisão é transmitir a relevância da informação de forma atraente, clara e natural, relatando a história com

precisão e síntese. Yorke (1998) menciona algumas características necessárias de quem atua nessa área: ser inteligente, ávido, paciente, curioso, persistente, ter sensibilidade para a notícia, compromisso com a verdade e adequada presença no vídeo.

Deparar-se com circunstâncias adversas como terremoto, rebelião, tiroteio em morros, plantões intermináveis na porta de hospitais, presídios e ministérios ou diante da casa de alguma celebridade exige uma imagem de profissional inabalável, firme e seguro. Para Barcellos (2003), o repórter televisivo é uma espécie de "guerrilheiro da notícia". O autor revela que falar ao 
microfone é uma tarefa cansativa, que se assemelha ao exercício de uma maratona, e que o sucesso da carreira depende muitas vezes de uma atuação de segundos no ar.

Ter conhecimento, experiência e boa cultura geral são competências essenciais para o perfil, pois o profissional terá mais facilidade para discernir a relevância de um fato, compreender em profundidade o assunto que vai investigar, buscar algo inusitado, redigir um texto adequadamente, exercer o distanciamento crítico, contextualizar e entender os acontecimentos com perspicácia e agilidade, exigências próprias do veículo televisão. A realização de uma entrevista requer preparo com antecedência, aprofundamento de todos os dados, conhecimento dos detalhes da trajetória do entrevistado e da notícia, bem como sobre qualquer situação ou assunto abordado, seja economia, política ou história, seja meio ambiente ou esportes.

Outro aspecto importantíssimo do perfil é a capacidade de conquistar e manter fontes criteriosas, bem como a relação de confiança estabelecida no telejornalismo investigativo ou em qualquer outra modalidade jornalística. Falar idiomas como o inglês, o espanhol e o francês amplia as possibilidades de pesquisas e o acesso a um maior número de fontes, o que diferencia o trabalho do profissional.

O adequado uso da voz no telejornalismo é fundamental, segundo Kyrillos e outros autores (2003), pois a imagem representada e o papel que o repórter desempenha no vídeo são fatores que refletem na efetiva comunicação do conteúdo da notícia, cujo maior desafio é fazer com que a mensagem seja recebida pelo público com credibilidade. O profissional precisa ter domínio de elementos verbais, como voz agradável, articulação clara, ritmo de fala, modulação, bom texto, adequada seleção vocabular e ordenação gramatical, bem como dos elementos nãoverbais, como expressão corporal, facial e gestual.

A expansão das novas tecnologias possibilita maior agilidade às coberturas e, portanto, requer engajamento total do telejornalista para conhecimento e manuseio de equipamentos digitais e uso freqüente do computador e internet.

Uma preocupação constante do repórter é a capacidade de trabalhar em equipe, principalmente com o repórter cinematográfico. Apesar da retaguarda de telejornalistas que o apoiaram na apuração da notícia, chefias e editores que o orientaram, o risco é, em tese, inteiramente do repórter, pressão que é uma importante característica do trabalho, fonte geradora de stress para o seu desempenho (COELHO, 2002). 
A fama instantânea que a televisão proporciona exige que o repórter aja com maturidade emocional e bom senso em todas as situações e o obriga a saber lidar com o glamour, com a auto-imagem exagerada de profissional bem-sucedido, que é confundido com o artista de novela. Ter humildade e ser colaborador são características importantes para o perfil, que também valorizam e diferenciam o seu trabalho junto à equipe, porque antes de tudo é o ser humano que está por trás da tela da televisão.

\subsection{Perfil do repórter cinematográfico}

O repórter cinematográfico pode ser chamado do jornalista da imagem. A imagem em televisão tem força preponderante, pois reforça a credibilidade da notícia, e o repórter cinematográfico é o cameraman ou cinegrafista, aquele que busca as informações por meio do recorte da realidade, ao escolher o melhor enquadramento e a melhor imagem pela câmera.

A função exige um perfil de grande sensibilidade artística para captar as melhores imagens jornalísticas, que dêem uma visão da cobertura como um todo. Para tanto é importante que o profissional seja jornalista de formação, para trabalhar de modo alinhado com o repórter, compreendendo a linguagem e compartilhando as informações da notícia.

A experiência e o conhecimento técnico no manuseio da câmera são competências fundamentais, o que implica adquirir visão ampla dos conceitos de telejornalismo, roteiro de documentário, iluminação, fotografia, planos e áudio. As câmeras, que antes pesavam mais de 16 quilos, hoje são bem leves e muito sofisticadas e seu manuseio exige conhecimento técnico bastante qualificado. O repórter cinematográfico é um profissional que precisa estar sempre atualizado e ter boa cultura geral, pois deve sempre buscar soluções novas e criativas para a linguagem de cinegrafia. Precisa saber colaborar e trabalhar em equipe, ter foco em resultados e proatividade para a busca de imagens inusitadas. As melhores reportagens em televisão são as noticiadas apenas por imagens, porque revelam uma situação que o público pode analisar da forma como desejar.

Em reportagens externas o trabalho em equipe prevalece e, quanto maiores o entrosamento e a cumplicidade entre repórter e repórter cinematográfico, maiores serão a contribuição para o resultado final e a garantia da veiculação de uma imagem, como a captação de um flagrante, em que a imagem é suficiente para contar a história. O encaminhamento da 
matéria e a definição de prioridades em parceria sobre o que será gravado precisam ser discutidos entre os dois profissionais, para que haja sintonia entre a imagem e o bom texto, pois a palavra esclarece a informação visual.

Dado que a atividade jornalística é muito dinâmica e a cada dia há uma matéria diferente a noticiar, o repórter cinematográfico é solicitado a atuar com muita agilidade e atenção diante dos fatos e a se adaptar a situações novas o tempo todo, bem como a criar estruturas pessoais emergenciais para se ajustar aos desafios, ou seja, para colocar a câmera na frente da situação, ser ousado, curioso e criativo.

Há vários aspectos técnicos do trabalho do repórter cinematográfico, como os expostos a seguir. O jornalista da imagem usa os recursos para guiar o telespectador para as partes do quadro que deseja enfatizar e dirige o olhar do telespectador para a informação. A escolha da lente adequada determina a perspectiva da imagem. Representar os objetos sobre um plano tal como se apresentam à vista é uma arte. Escolher a lente correta também é importante, porque é ela que vai determinar o plano que melhor descreve a cena.

Outro ponto é escolher o local para executar uma gravação, decisão que pode ser tomada em segundos ou demorar horas. Essa procura vai depender do tempo disponível para a realização do trabalho. Quando o repórter cinematográfico toma a decisão, é porque já encontrou boa parte das condições necessárias para a gravação, e uma delas é certamente a composição do quadro da notícia a ser mostrada. A técnica de iluminação, habilidade essencial do repórter cinematográfico, é uma mistura de conhecimento técnico e sensibilidade artística. É a iluminação, e mais especificamente a quantidade de luz, que destaca a textura, as cores, o formato dos objetos e que depois, na imagem pronta, vai influenciar a visão do público.

Outro aspecto fundamental é a composição da imagem, que consiste em arranjar os elementos dentro do quadro a ser fotografado, posicionar o elemento principal de modo a atrair a atenção do telespectador, determinar o equilíbrio das cores e formas, quantificar e qualificar a iluminação, tornar a imagem comunicativa e esteticamente agradável. É a imagem que faz com que o público seja atraído e absorva as informações recebidas. O telespectador capta mais as imagens do que um texto. 


\section{O PADRÃO ESPERADO}

Toda empresa de televisão tem um padrão esperado de atuação dos seus jornalistas. A empresa pesquisada requer um bom padrão de competência e desempenho dos seus profissionais, e estes são acompanhados diariamente, a cada reportagem.

Algumas características do desempenho dos sujeitos podem ser avaliadas segundo uma simples constatação, como a pontualidade e a assiduidade no trabalho; outras são apropriações que dependem do julgamento externo e do padrão definido pela empresa, que são formulados com base em valores subjetivos, fruto do consenso da troca de percepções e discussões constantes entre os gestores e as diretrizes da empresa. As conclusões dão o norte com relação ao que é realizar plenamente as funções telejornalísticas e definem qual é o padrão "ideal" de competência e desempenho profissional.

Destacaremos alguns tipos de competência no paradigma emergente de gestão, que variam de acordo com as demandas apresentadas e a estrutura organizacional: rotina, estratégia, crise e urgência. Exemplifiquemos. Se a demanda for atender a rotina, como "noticiar um buraco de rua que provoca engarrafamentos no trânsito", a postura do sujeito poderá ser conservadora e atenderá ao padrão esperado. Se a demanda for de estratégia, a mudança poderá ser mais controlada e o padrão esperado será conforme as ações planejadas e as respostas exigidas serão a longo prazo, como numa situação de cobertura das eleições municipais.

As demandas também poderão revelar crise, ou seja, os problemas são tantos que a estrutura organizacional não dá mais conta, e nessa situação o nível de competência do sujeito deverá ser elevado, com extrema flexibilidade às diferentes situações e adequada capacidade de coping diante dos vários agentes stressores, como quando se realizam muitas coberturas em vários turnos para suprir falta de pessoal. Por último, as demandas poderão indicar urgência e requer respostas imediatas do sujeito a cada nova situação ou também elevado nível de competência, proatividade, ousadia, agilidade na checagem de informações e adequado coping, como nas entradas ao vivo da cobertura de um acidente aéreo ou em plantões no local de um acidente, como o ocorrido no metrô de São Paulo em janeiro de 2006.

O padrão de desempenho e competência definido pela empresa pesquisada privilegia os telejornalistas capazes de apresentar resultados diante da demandas de crise e urgência, pois são os que atendem ao modelo de gestão emergente, em que são valorizados o conhecimento, a 
experiência, o estilo, a desenvoltura e o domínio técnico, para que a empresa possa despontar diante da competitividade e do contexto de imprevisibilidade.

Coelho (2002), ao pesquisar os jornalistas de televisão, refere que o perfil esperado é aquele propenso ao stress, em que o impacto sobre o indivíduo está diretamente relacionado à sua capacidade de utilizar adequadamente estratégias de reação ao stressor (coping). As competências estão ligadas a um perfil de profissional arrojado, determinado, capaz de desenvolver múltiplos projetos e, em alguns casos, com um carisma que realce suas produções jornalísticas e que gere eustress. A adesão irrestrita a esse perfil, por outro lado, implica também uma intensa dedicação, com clara repercussão na vida pessoal, tendo em vista o elevado comprometimento e a disponibilidade integral para o trabalho, o que exige do sujeito respostas num nível acima do seu repertório atual, o que poderia levar ao desenvolvimento do distress.

Considerando os estudos de Baker e Karasek (1999, apud LIMONGE E RODRIGUES, 2002), já mencionados no capítulo III deste trabalho, como referenciais sobre stress ocupacional e comparando-os com os aspectos do ambiente do telejornalismo e a natureza da tarefa, podemos inferir que alguns fatores stressores estão presentes no cotidiano da redação: exigências de tempo (necessidade do sujeito fazer horas extras para cumprir demandas por crise ou urgência), estrutura temporal (trabalhos em turnos e plantões, de acordo com os fatos e eventos) e ritmo (agilidade constante para atender ao fechamento dos telejornais), organização do trabalho (controle e cobrança por resultados, conflitos de gestão, competição, necessidade de reconhecimento profissional, maior retorno do desempenho e ações de desenvolvimento profissional) e fatores extra-organizacionais (insegurança no trânsito e em locais de maior violência e preocupação com carreira e empregabilidade).

Conforme os mesmos autores, há fatores que funcionam como moderadores do stress e que dependem da estrutura da empresa, da gestão e da forma de organização do trabalho. Ao analisarmos o ambiente de trabalho e a estrutura organizacional em que a presente pesquisa foi desenvolvida, podemos inferir que há alguns moderadores de stress: estrutura das tarefas (os sujeitos têm bom grau de autonomia de ação, participação no desenvolvimento e nos resultados da área e são aproveitados de acordo com as suas capacidades), condições físicas (há constante cuidado e monitoramento dos riscos físicos e ergonômicos por parte da empresa e investimento em equipamentos novos), organização do trabalho (a estrutura organizacional é clara, com níveis de reporte hierárquico bem definidos, assim como os papéis e responsabilidades, e com tomadas 
de decisão dentro do escopo de responsabilidade da função) e fatores exteriores ao trabalho (empresa dá adequado suporte social aos sujeitos e à família).

\section{COMPORTAMENTO TIPO A}

Coelho (2002) identificou que o padrão de comportamento típico do jornalista é o do tipo A, que consiste na apresentação de características próprias de um perfil competitivo, em que o sujeito se identifica com a luta crônica por alcançar metas maiores e se propõe à execução de várias atividades num curto espaço de tempo, demonstrando constante preocupação com o senso de urgência no trabalho e com o cumprimento dos fechamentos dos telejornais (deadlines).

A autora realizou pesquisa com 32 telejornalistas (repórteres e apresentadores) e verificou que os resultados quanto ao padrão de comportamento tipo A se mantiveram na classificação "nível alto" nos grupos pesquisados. Ela afirma: "Faz parte da rotina do telejornalista atingir mais resultado em menos tempo. Por um lado, é esperado que ele produza muito, por outro lado ele próprio busca essa alta produção e perfeição. Dessa forma, essa situação não é vista como algo que lhe foi imposto e que é nocivo a ele. A cobrança parece combinar perfeitamente com o perfil de personalidade dos sujeitos. A competição também é motivadora para eles e o desafio é visto com muito prazer".

Cooper e outros autores (1980) revelaram que o profissional com esse padrão de comportamento facilmente se expõe a situações estressantes, responde com hiperatividade, hostilidade, ambição, impaciência e irritabilidade e, quando forçado a trabalhar de forma mais lenta, decresce em desempenho e sofre mais tensão. Da mesma forma, tem necessidade de controlar o ambiente em que está, ignora sintomas físicos e psicológicos se acredita que o trabalho desempenhado ainda não foi concluído e tende a perceber menos distress quando está ativamente engajado no trabalho.

Cooper e Baglioni (1988) pesquisaram que a intensidade da experiência de stress é determinada pelo padrão de personalidade (tipo A), pelo nível de percepção dos stressores e pelas habilidades de coping cognitivo e emocional do indivíduo. O padrão tipo A e o tipo B reagem de modo diferente diante de stressores e utilizam técnicas de coping diferenciadas. Especificamente, o padrão tipo A é mais competitivo, mais ágil nas atividades e mais sensível em perceber os stressores do ambiente, e reagindo a eles com mais intensidade, do que o tipo B. 
Barling e Boswell (1995) estudaram o desempenho e o comportamento tipo A e analisaram duas dimensões distintas: a necessidade de lutar para alcançar um objetivo e a irritabilidade/ impaciência, que podem ter, segundo os autores, relação direta ou indireta com o desempenho. A base desse estudo foi o fato de as empresas valorizarem o desempenho das pessoas de comportamento competitivo do tipo A. Os resultados demonstraram que não é conclusivo que o comportamento tipo A conduza a um melhor desempenho, porém os autores chegaram a algumas considerações importantes: a dimensão de luta e esforço é um indicador que leva os sujeitos a se concentrarem com maior atenção no que fazem, portanto é uma dimensão diretamente relacionada ao desempenho no trabalho, enquanto a dimensão de irritabilidade e impaciência é indicativa de problemas de saúde e dificulta a concentração das tarefas.

Tamoyo (2004) afirma que os estudos sobre a influência de fatores de personalidade no processo de stress não são conclusivos, porém acredita que exista essa influência e que ela depende do grau de exposição do sujeito aos stressores e dos fatores de personalidade desenvolvidos, pois a auto-estima, a auto-eficácia e o otimismo podem funcionar como moderadores de stress. 
Jornalistas em geral se queixam de stress. Embora alguns pesquisadores dêem ênfase a essa questão, poucos são os estudos que reúnem evidências mais sistematizadas sobre os efeitos do stress em profissionais de jornalismo de televisão ou meio impresso, sejam eles jovens ou com grande experiência na profissão. Tais profissionais permanentemente apresentam notícias sobre situações estressantes (calamidades, tiroteios), porém raramente revelam suas próprias experiências estressantes enquanto realizam as coberturas. As fontes de informação sobre seus depoimentos estão em textos e livros, mas pouco se trata disso em pesquisas.

Fedler (2004) estudou por volta de 100 biografias, 150 autobiografias, 250 artigos em revistas, 20 livros de artigos específicos e 200 sobre assuntos correlatos ao stress em jornalismo e identificou que poucos são os profissionais que fazem uma reflexão sobre como vivenciam eventos stressores. O autor faz uma relevante revisão da literatura do período de 1850 a 1990 e demonstra que antes de 1930 o conceito de stress não era difundido no meio jornalístico e que mesmo atualmente as pesquisas estão na fase inicial com relação a documentar os níveis e os efeitos do stress nas redações.

Foi eminentemente nas décadas de 80 e 90 que o stress e seus efeitos passaram a ser fatores reveladores na vida e no trabalho dos jornalistas. O contexto adverso e competitivo e a natureza da tarefa conduzem o repórter, particularmente, a se expor a situações sombrias, ver a morte de perto, entrevistar vítimas e parentes em situações de sofrimento, e o que se espera do seu desempenho é que saiba ignorar suas necessidades emocionais e físicas enquanto testemunha tragédias e não se mostre vulnerável ao stress.

Fedler (2004) cita algumas pesquisas relevantes sobre como o stress pode afetar o jornalista, diminuindo sua produtividade pelo aumento do absenteísmo e rotatividade. São elas:

- Simpson e Boggs (1999) revelaram que 86\% dos jornalistas pesquisados, que se deparavam com cenas violentas, evidenciavam reações cumulativas de stress e sofriam posteriormente sintomas psicológicos, como pesadelos, depressão, irritabilidade, ansiedade, dificuldade de concentração e problemas conjugais, e sintomas físicos, como distúrbios de alimentação, sono, pressão alta e problemas cardíacos.

- Joseph (1983) concluiu que jornalistas são mais propensos ao alcoolismo - cerca de duas vezes - do que a população em geral. 
- Endres (1988) demonstrou que 90\% dos repórteres entrevistados revelavam stress e que após seis anos de atuação havia reflexos na vida profissional e pessoal; que 50\% pensaram em desistir da profissão, 40,8\% tiveram depressão e que $38 \%$ pensavam em deixar o emprego.

- Pease (1992) mostrou que 50\% dos pesquisados não recomendariam a carreira a seus filhos. Além dessas conclusões, Fedler (2004) ressalta que as mulheres apresentam maior vulnerabilidade ao stress, devido a problemas familiares e ao menor tempo para acompanhar os filhos e para o descanso.

A maneira como os jornalistas lidam com as situações (coping) também é muito importante. Jovens jornalistas ainda vêem a profissão como uma aventura e são atraídos pela diversidade, o estímulo e a oportunidade de estarem constantemente em contato com "cenas", com o glamour e encontrarem personalidades famosas, portanto olham a carreira com orgulho e elogiam o trabalho pesado mais do que criticam o lugar em que trabalham (FEDLER, 2004).

O mesmo autor apontou os nove principais fatores de stress no jornalismo:

1. reputação profissional: jornalistas preocupam-se com sua imagem e acreditam que são vistos como uma "categoria à parte" pela população, como rudes, intrusos, cínicos, sem maneiras, desonestos, suspeitos, esquentados e difíceis de lidar;

2. sacrifício e compromisso com seus ideais: é esperado que recebam orientações de seus superiores, porém precisam saber conciliá-las com ideais pessoais (missão de informar a sociedade), lucro e objetivos organizacionais conflitantes;

3. demanda física e mental de trabalho: esforços de deslocamento e permanência de horas nos locais, bem como execução com mais rapidez do que o jornalista é capaz de fazer;

4. jornada de trabalho com longas horas e períodos irregulares;

5. salário baixo se comparado com a carga de trabalho e nível de exigências requeridas (inteligência, versatilidade e iniciativa);

6. competição intensa por matérias;

7. insegurança: saber enfrentar pessoas dos mais diferentes níveis sociais e não se intimidar por medo;

8. situações de calamidades que testemunham: é preciso ter autodisciplina e autocontrole;

9. conflitos com chefias não preparadas para a gestão de pessoas. 
As análises realizadas por Wines (1986) e Fedler (2004) mostram que os jornalistas apontam para algumas formas de autogerenciamento do stress:

- O distanciamento emocional: o jornalista é treinado a condicionar suas emoções e a manter o foco nas questões profissionais para conseguir notícias. Ele é avaliado com reconhecimento quando consegue transmitir o fato com neutralidade, parecendo não ser afetado pelo sofrimento que vê. Alguns jornalistas confirmam que seu trabalho os torna pessoas difíceis, duras e irreverentes. Para o profissional, um desastre pode não ser uma catástrofe mas uma história. Há a prevalência da avaliação da relevância do fato, a veracidade, a notícia "quente", o furo da reportagem frente à concorrência, o fascínio pelo que vê: o conflito, a violência, o bizarro, o exótico e o anormal, em que as vítimas nem sempre são vistas como pessoas, mas como personagens. Embora o compromisso com a notícia seja positivo, o esforço intenso e prolongado de manter o distanciamento pode levar a um custo somático e emocional elevado, que compromete o desempenho.

- O envolvimento com álcool, abuso da cafeína e fumo: são estratégias para resistir a horas estressantes, à aproximação do deadline e a situações ao vivo e para buscar equilibrar o stress.

- A dificuldade para lidar com a tensão e nervosismo: reflexos e repercussão na vida profissional e pessoal, com sintomas de exaustão (burnout).

- O abandono do trabalho, o redirecionamento ou a mudança de vida.

Coelho (2002) apontou que as características inerentes ao trabalho em jornalismo, como pressão do tempo, competitividade e insegurança no emprego, se acentuam ainda mais no telejornalismo, pois é intensa a exposição diária a fontes externas geradoras de stress, tais como o imediatismo, o cumprimento do deadline, cobranças das chefias, problemas técnicos em situações externas e vários outros stressores que extrapolam o controle. A pesquisadora também apresenta resultados da pesquisa da FENAJ (Federação Nacional dos Jornalistas), em que destaca que os principais agentes stressores: horários irregulares de trabalho, descanso semanal comprometido por plantões e escalas nos feriados e finais de semana, ansiedade constante, competição, ritmo ágil, exigência por elevado grau de acerto. Em pesquisa realizada no Ceará, a presença de stress no trabalho foi verificada em 44,12\% dos entrevistados e a insatisfação no trabalho, em $66,91 \%$. 
Heloani (2003) pesquisou 44 jornalistas e avaliou que o jornalismo é uma categoria bastante afetada pelos níveis de stress, com predominância de sintomas mais psicológicos do que físicos, com destaque para: falta de tempo dos sujeitos, dificuldade de constituir uma família, baixos salários, questionamento quanto à solidez da formação acadêmica, carga horária de trabalho elevada, esfera profissional que se confunde com a vida pessoal e paixão pela profissão.

Reinardy (2007) percorreu o ambiente organizacional das redações de jornalismo impresso americanas e constatou, através de pesquisa, que o nível de stress tem se elevado próximo ao burnout, devido aos grandes impactos que a imprensa americana vem sofrendo ano a ano, com a queda no volume de vendas e a escalada crescente da internet. A pesquisa contou com a participação de 770 jornalistas e apontou também baixo nível de eficácia no trabalho e de comprometimento dos pesquisados.

Os depoimentos dos sujeitos demonstram grande insatisfação, que está diretamente relacionada aos conflitos de gestão e à falta de convergência entre os interesses da empresa e os dos jornalistas. Uma respondente apontou alguns motivos de descontentamento: "baixos salários, horas de trabalho em excesso, falta de pessoal, favoritismo, programas de computador inadequados, quantidade insuficiente de repórteres para cobrir eventos, ausência de bonificação, promoção de pessoas com pouca experiência, tratamento e distribuição de tarefas de modo desigual".

A pesquisa revela resultados preocupantes; indiferença, falta de comprometimento e distanciamento do trabalho, características que apareciam em outras categorias profissionais mas não entre jornalistas, que sempre consideraram sua profissão diferenciada. Esse estudo revela que não se trata apenas da atual crise na mídia impressa, mas de questões internas sobre a cultura e a gestão, que afetam desempenho, satisfação, turnover e que conduzem a elevados níveis de stress.

Atualmente várias pesquisas têm sido desenvolvidas em busca de um melhor entendimento do processo de stress e sobre como este afeta as mais diversas categorias profissionais: juízes (LIPP e TANGANELLI, 2002), professores (PEREIRA, 2003), enfermeiros (GUERRER, 2007), entre outras. Estudos de profissões menos conhecidas, também revelam investigação entre stress e desempenho. Oberlechner e Ningade (2005) pesquisaram profissionais tomadores de decisão do mercado financeiro e investigaram os fatores associados a stress e desempenho. Os resultados indicaram que 32\% dos sujeitos revelaram elevadíssimo 
nível de stress, provocado pela necessidade de atingir metas e enfrentar longas jornadas de trabalho. O stress ocupacional mostrou-se vinculado a quatro fatores: pressão por lucro, pressão social, sobrecarga de trabalho e processo decisório. 
IV. OBJETIVOS 


\section{OBJETIVOS}

\section{OBJETIVO GERAL}

O objetivo geral da presente pesquisa é estudar o nível de stress e sua relação com o nível de desempenho profissional em telejornalismo, especificamente repórteres(R) e repórteres cinematográficos (RC), de uma empresa de televisão privada. Pretende-se comparar também o stress com o nível de habilidades/competências técnicas, bem como com o padrão de bom desempenho definido pela empresa e o padrão de comportamento tipo A.

\section{OBJETIVOS ESPECÍFICOS}

1) Construir um instrumento de avaliação de desempenho para as duas funções do telejornalismo, que poderá ser utilizado pela empresa.

2) Estudar os grupos R (repórteres) e RC (repórteres cinematográficos) separadamente e compará-los quanto:

a) ao stress - "lista de sintomas" (LSS/VAS): presença, freqüência, intensidade, nível geral de stress e fase de stress;

b) ao padrão de comportamento tipo A (BEPATYA) através de seu nível e nos fatores: ambição, impaciência, senso de competência, auto-sobrecarga, nervosismo, incapacidade de desligar-se e urgência de tempo;

c) à competência

d) ao desempenho.

3) Analisar outras possíveis intercorrelações em cada grupo, considerando-se as variáveis demográficas e os resultados dos instrumentos do item 2 acima.

4) Estudar a amostra total de telejornalistas $(R+R C)$, estabelecendo as possíveis intercorrelações entre todas as variáveis pesquisadas. 


\section{MÉTODO}




\section{CONSIDERAÇÕES GERAIS}

Trata-se de uma pesquisa de caráter exploratório e quantitativo, em que se buscou medir em termos numéricos os fenômenos como os níveis de desempenho, habilidades e competências, bem como os níveis de stress.

A pesquisa a ser relatada a seguir, sob a ótica ontológica, epistemológica e metodológica (método, técnicas de pesquisa e procedimentos), foi fundamentada no paradigma pós-positivista, segundo a diferenciação de paradigmas científicos feita por Guba (1990) e Tassara (2006).

\section{AMOSTRA}

Na pesquisa buscamos estabelecer correlações entre variáveis específicas, dentro de um recorte da realidade delimitado por dois cargos (repórter e repórter cinematográfico) que interagem e que são co-responsáveis por um mesmo produto final (telejornalismo).

A população estudada é composta por 40 profissionais: 20 repórteres (identificados como R) e 20 repórteres cinematográficos (identificados como RC), funcionários de uma mesma empresa de comunicação, localizada em São Paulo. Visando a uma maior representatividade da amostra, esta pesquisa abrangeu $57 \%$ da população total de repórteres ( $\mathrm{t}=35)$ e $52 \%$ da população total de repórteres cinematográficos $(\mathrm{t}=38)$ com atuação nos telejornais dessa localidade.

Para maior uniformidade da amostra foi considerada apenas uma emissora de televisão, para que pudéssemos focalizar a mesma cultura organizacional permeada pelos mesmos fatores ambientais, valores e princípios, procedimentos e ritmo de trabalho, gestão, nível de exigência e de autonomia, padrão de qualidade, qualificação, habilidades e competências técnicas e desempenho dos profissionais.

Para mantermos o padrão dos critérios amostrais dos cargos, foram considerados os profissionais pertencentes às equipes dos telejornais de São Paulo, que apresentam as mesmas descrições de função. 
Outra característica comum dos sujeitos dos dois cargos pesquisados é a atuação em campo, ou seja, fora da emissora. Eles realizam entrevistas e matérias sob circunstâncias imprevistas na grande metrópole de São Paulo.

Os testes aplicados e o processo de avaliação de desempenho foram conduzidos no mesmo período para todos os sujeitos, entre o final de novembro de 2006 e o final de janeiro de 2007, para garantir que estivessem no mesmo espaço temporal, vivenciando o mesmo momento histórico localmente, a mesma ocorrência de fatos jornalísticos, bem como as mesmas variáveis do ambiente interno na empresa.

\section{MATERIAIS E INSTRUMENTOS}

A pesquisa envolveu a coleta de dados com base no formulário sobre dados pessoais, nos testes Bepatya (behavior patterns type A) e LSS/VAS (lista de sintomas de stress) e na planilha de avaliação de desempenho, habilidades e competências técnicas, instrumentos detalhados a seguir.

\subsection{CARACTERIZAÇÃO DA AMOSTRA}

\subsubsection{Formulário de caracterização da amostra (Anexo 1)}

Foi elaborado um formulário para o levantamento dos dados dos sujeitos, com os seguintes campos: sexo, idade, estado civil, número de filhos, grau de escolaridade, formação acadêmica, tempo na empresa, tempo total de profissão, horas de trabalho/dia e emprego paralelo.

\subsection{AVALIAÇÃO DAS VARIÁVEIS PSICOLÓGICAS}

Foram aplicados dois testes, um da dimensão psicológica e uma avaliação cognitiva do stress nos sujeitos.

\subsubsection{Teste Bepatya - Behavior Patterns Type A}

Esse teste foi desenvolvido por Vasconcellos e Brengelmann (1985) e traduzido, adaptado e validado para a população brasileira por Vasconcellos (1991). O teste possibilita investigar o nível estrutural de stress, levantar o perfil do sujeito diante de situações gerais da vida e especificamente identificar o padrão de comportamento tipo A. 
O teste consiste em uma lista de 21 afirmações sobre as quais sujeito deverá exprimir o seu grau de concordância ou não, na seguinte disposição: 0 (não); 1 (bem pouco); 2 (pouco); 3 (médio), 4 (bastante) e 5 (totalmente). São sete os fatores avaliados: senso de competência, nervosismo, nível de ambição, impaciência, incapacidade de desligar-se, auto-sobrecarga e urgência de tempo, que serão definidos abaixo. Níveis altos representam maior risco na relação entre stress e saúde.

Senso de Competência: Vê-se mais competente que os demais; acredita saber e fazer melhor que os outros. Tem grande necessidade de reconhecimento e faz de tudo para ser elogiado e admirado, colocando-se sempre no centro das atenções. Conta com notada ênfase de sua competência, como fez e resolveu bem os problemas.

Nervosismo: Tendência a responder com nervosismo e alta irritabilidade às exigências e demandas; tem pouco auto-controle quando nervoso e descarrega sua irritabilidade nos demais; É hostil ao falar, interperlar ou questionar alguma coisa com as pessoas.

Nível de Ambição: Tem alto nível de ambição, deseja alcançar muito sucesso na carreira profissional e na aquisição de bens materiais. Pensa muito centrado nas questões financeiras e não se dispõe a colaborar com algum projeto se não lhe trouxer benefícios e oportunidade de promoção pessoal ou profissional.

Impaciência: Tem dificuldade de esperar e demonstra comportamento ansioso quando, por força das circunstâncias, necessita aguardar o resultado de algum processo, pessoa ou situação (trânsito, banco, laboratório). Sente-se irritado quando percebe alguém fazendo devagar e calmamente a tarefa que lhe foi designada, preferindo fazê-la ele mesmo.

Incapacidade de desligar-se: Não consegue desligar-se de compromissos e tarefas que tenha para resolver. Não consegue dormir relaxadamente enquanto não concluiu a tarefa. Substitui e sacrifica seu horário de lazer, compromissos familiares e sociais pelo trabalho. Apesar de seu dia de trabalho se estender para além do horário habitual, faz longos períodos de hora extra e leva trabalho para casa. Mesmo quando em desfrute de alguma atividade de lazer, fala do trabalho, conta o que está fazendo, faz do tema empresa o principal tema da conversa. 
Auto-Sobrecarga: Não tem senso de limite, assume compromissos e tarefas mesmo não tendo possibilidade de executá-las por já estar muito sobrecarregado com os compromissos que tem. Consegue fazer varias coisas ao mesmo tempo. Não sabe dizer não a convites e pedidos, desde que anteveja neles uma oportunidade de destacar-se dos demais.

Urgência de tempo: Deseja fazer tudo rapidamente e no menor espaço de tempo. Sente-se bem quando trabalha sobre pressão de tempo, demonstrando muitas vezes melhor desempenho do que quando dispõe de tempo para executar a tarefa. Tem pressa e apressa os demais. Vive com a sensação de estar atrasado e em débito com o tempo.

\section{2.2. Teste LSS/VAS - Lista de Sintomas de Stress}

Esse teste foi desenvolvido e atualizado por Vasconcellos (2001) e validado para a população brasileira. Consiste em uma lista de 59 afirmações que se referem aos sintomas de stress de natureza fisiológica, emocional, cognitiva e social. Cada sujeito indica os sintomas de stress do ponto de vista da presença, freqüência e intensidade dos sintomas.

$\mathrm{O}$ teste pede que se assinale a freqüência, que varia de 0 a 3: 0 (nunca), 1 (raramente), 2 (freqüentemente), 3 (sempre), e em seguida a intensidade, que deve ser marcada com um $\mathrm{X}$ sobre uma escala que mede 10 centímetros, sendo 0 a intensidade mínima e 10 a intensidade máxima. A freqüência de sintomas é medida por pontos: 0 a 12 (inválido); 13 a 59 (baixa); 60 a 118 (média) e mais que 118 pontos (alta).

Esse instrumento permite verificar a presença de sintomas: até 10 sintomas - a presença é baixa; de 11 a 20 - média; mais que 20, é considerada alta a presença de sintomas de stress. A intensidade dos sintomas varia de 0 a 10 e é verificada pelos índices: 0 a 3,33 (baixa); 3,34 a 6,66 (média) e mais que 6,66 (alta).

O teste mede também o nível geral de stress, que pode ser baixo, médio, médio-alto, alto e altíssimo, e as fases do stress, designadas como leve, alarme, perigo, perigo agudo e exaustão. 


\subsection{PLANILHA DE AVALIAÇÃO - COMPETÊNCIA E DESEMPENHO}

A planilha de avaliação de competências e desempenho foi elaborada a partir da descrição dos cargos de repórter e repórter cinematográfico, já referida anteriormente. A descrição de cada cargo foi realizada com base na análise dos materiais: classificação brasileira de ocupações (CBO) do Ministério do Trabalho e Emprego - código 2617 (Locutores, Âncoras e Repórteres de Rádio e Televisão) para repórter e código 2611 (Profissionais de Jornalismo) para repórter cinematográfico; dicionário de profissões (págs. 336-340); e por meio de observações e do conhecimento da pesquisadora em contato diário com o trabalho desses profissionais (1). A descrição de cargo contém as seguintes informações: requisitos do cargo, descrição sumária, descrição detalhada e condições de trabalho (Anexos 2A e 2B). Também se utilizaram os referenciais citados por Dutra (2002), como parâmetro para a elaboração dos instrumentos de avaliação, e que foram adaptados para a população estudada. Não houve participação das chefias nessa etapa do trabalho.

As planilhas de avaliação de competência e desempenho de $\mathrm{R}$ e RC seguem a mesma formatação, sendo cada planilha composta de duas partes: a primeira avalia as habilidades e competências técnicas do cargo, a segunda avalia o desempenho profissional. As planilhas préformatadas foram validadas posteriormente por chefias e profissionais de telejornalismo em uma emissora de televisão situada fora da cidade de São Paulo.

$\mathrm{Na}$ avaliação do repórter, os itens da lista de competências são (anexo 3 A):

- formação acadêmica (grau de escolaridade);

- experiência (prática profissional na realização de matéria jornalística e domínio da linguagem de televisão);

- conhecimentos (língua portuguesa escrita e falada, idioma inglês falado, técnica de expressão no vídeo, fontes, produção de reportagem e edição, tecnologia).

(1) Fontes consultadas:

a) CBO - Classificação Brasileira de Ocupações do Sistema Nacional de Emprego - SINE

Ministério do Trabalho, Brasília, 1982. Na elaboração, o Ministério do Trabalho contou com a colaboração técnica da Organização Internacional do Trabalho - OIT, através do projeto de Planejamento de Recursos Humanos, BRA/70/550.

b)Dicionário das Profissões do Centro de Integração Empresa-Escola - CIEE, Divisão Técnica, $3^{a}$ edição, Revista, atualizada e ampliada, São Paulo, 1981. 
Os itens de avaliação de desempenho da planilha de repórter são (anexo 3 A):

- visão do processo (se realiza suas atividades com profundo conhecimento do processo de produção da notícia, da pauta à edição, em qualquer produto jornalístico);

- cumprimento de metas e resultados (se entrega as reportagens dentro dos prazos estabelecidos, adequadas para exibição em qualquer produto jornalístico, em diferentes jornais e programas da emissora, tanto do ponto de vista técnico quanto editorial; se tem foco na notícia e consegue adequar o texto à imagem);

- trabalho em equipe (se sabe relacionar-se com os profissionais da redação e de outras áreas da empresa de forma colaboradora e flexível, revelando senso de equipe);

- inovação (se apresenta idéias inovadoras para a realização de matérias jornalísticas);

-comprometimento profissional (se oferece rotineiramente pautas viáveis, fundamentadas em levantamento prévio de informações, e colabora nas atividades da redação);

- qualidade do texto (se redige matérias claras e corretas, quanto às informações e ao uso da língua portuguesa, adequadas à linha editorial);

- planejamento e análise (se está diariamente informado e atualizado, se realiza pesquisa aprofundada sobre os assuntos em pauta, se desenvolve planejamento cuidadoso ao realizar uma reportagem, bem como se analisa, interpreta e correlaciona informações com boa base crítica);

- comunicação e imagem no vídeo (se transmite cuidado com a imagem visual, credibilidade e empatia junto ao público, bem como se consegue expressar-se com clareza, segurança e domínio da situação no vídeo);

-atualização profissional (se participa de atividades que promovem autodesenvolvimento e se busca expandir conhecimentos de forma contínua - pela leitura de livros e aprimoramento da cultura em geral, por cursos técnicos em jornalismo ou em outras áreas, como as de documentários, cinema e idiomas).

$\mathrm{Na}$ planilha de repórter cinematográfico, consideram-se as seguintes competências (anexo 3B):

- formação acadêmica (grau de escolaridade);

- experiência (prática profissional no uso da câmera e na captação de imagens de assuntos de interesse jornalístico em gravações e /ou transmissões e domínio da linguagem visual do produto jornalístico); 
- conhecimentos (uso de equipamentos, técnicas de iluminação, enquadramento, planos e fotografia, técnicas de narrativa visual, kit correspondente, edição de imagem e idioma inglês falado).

Para avaliar o desempenho dos repórteres cinematográficos consideram-se os itens (anexo 3B):

- visão do processo (se realiza suas atividades com profundo conhecimento do processo de produção da notícia em qualquer produto jornalístico, da pauta à edição);

- cumprimento de metas e resultados (se entrega o material cinematográfico dentro dos prazos estabelecidos, sem prejuízo da qualidade técnica e com adequação editorial aos produtos, para diferentes jornais ou programas da emissora);

- trabalho em equipe (se sabe relacionar-se com colegas - da externa e da redação - de forma colaboradora e flexível, revelando senso de trabalho em equipe, se contribui na rotina profissional para o desenvolvimento do trabalho de todos);

- inovação (se oferece idéias inovadoras na realização de matérias jornalísticas, se sugere novas metodologias para o desenvolvimento do trabalho e do grupo);

- senso de oportunidade (se faz captação com agilidade, é atento ao que se passa ao redor e cria oportunidades, buscando imagens diferenciadas, como flagrantes e furos);

- participação jornalística (se está sempre informado sobre as notícias e participa ativamente da reportagem em que está envolvido, com sugestão de imagens, pautas e indicação de fontes);

- comprometimento (se compreende as necessidades do jornalismo, se é pontual, dedicado e responsável, se tem consciência da repercussão de suas atitudes no trabalho e sabe equilibrar interesses pessoais com os da empresa);

- atualização profissional (se participa de atividades que promovem autodesenvolvimento e busca expandir conhecimentos de forma contínua - por meio de leitura de livros e cultura em geral, cursos técnicos, documentários, cinema, idiomas - e se compartilha os conhecimentos com os colegas de profissão).

Utilizou-se como critério de classificação dos sujeitos a conceituação NA, ED, A e S, conforme o modelo de Dutra (2002), com adaptações para a população estudada:

Nível 0 - NA (sujeito que não atende ao esperado para o cargo), 
Nível 1 - ED (sujeito que está em processo de desenvolvimento no cargo),

Nível 2 - A (sujeito que atende plenamente ao esperado para o cargo),

Nível 3 - S (sujeito que supera o esperado para o cargo).

\subsubsection{Validação de Conteúdo (Anexo 4)}

O instrumento, após sua elaboração, foi submetido à validação de 12 sujeitos, por meio da técnica de análise e validação de conteúdo. Trata-se de uma validação de conteúdo porque consistiu da consulta a "seis juízes" que analisaram o conteúdo de cada planilha de avaliação, para os dois cargos separadamente. Escolheu-se uma outra unidade da emissora, situada numa cidade do interior de São Paulo, em local diferente de onde foi aplicada a pesquisa, e submeteram-se os instrumentos à validação. Três repórteres e três chefias fizeram análise de conteúdo da planilha de repórter. Outros três repórteres cinematográficos e três chefias fizeram análise de conteúdo da planilha de repórter cinematográfico.

Para realizar a validação levaram-se em conta os dois fatores da planilha de repórter cinematográfico e de repórter: competência e desempenho. No fator "competência", tínhamos três variáveis: formação acadêmica, experiência e conhecimentos. O item "conhecimento" se subdivide em seis subitens, que são específicos e diferentes para cada um dos cargos, conforme já exposto. No fator "desempenho" havia nove variáveis para repórter e oito variáveis para repórteres cinematográficos, também já mencionadas.

Utilizou-se de procedimentos homogêneos e um único parâmetro para os dois cargos, ou seja, cada cargo foi avaliado por seis juízes, obtendo-se uma correlação 1:6. Cada variável foi avaliada em seis categorias por 6 juízes, obtendo-se a correlação 1:36. As categorias de validação foram: clareza, objetividade, simplicidade, sintaxe, compreensão e relevância.

Considerou-se a correlação das seis categorias para os seis juízes que realizaram a validação e obteve-se para cada item de competência a correlação 6:36. Dessa forma, foi considerado o índice de $85 \%$ de concordância nas respostas para que a planilha tivesse validade e $15 \%$ de discordância como índice aceitável.

Considerou-se como aceitável o índice de 13,9\%, ou seja, a cada cinco discordâncias em cada item, analisando-se o conjunto todo e o item na horizontal. Considerando cada item separadamente, foi considerada aceitável até uma discordância, ou seja, índice de 0,9\%; se fosse $>1,0, \mathrm{o}$ item seria alterado. 
Alguns comentários dos juízes não eram discordâncias, mas sugestões, que foram consideradas por se tratar de contribuições valiosas para o aprimoramento do instrumento, como "visão de produtos" para a planilha de repórter cinematográfico.

\subsubsection{Perfil Padrão de Desempenho Definido pela Empresa (Anexos 5A e 5B)}

A definição do padrão de desempenho foi realizada por dois gestores em posição hierárquica superior ao grupo de repórteres e por dois gestores em posição hierárquica superior ao grupo dos repórteres cinematográficos. O objetivo foi definir o "padrão de bom desempenho" da empresa para servir de parâmetro para o cálculo do resultado da avaliação final de cada sujeito.

Essa referência também possibilita identificar as lacunas (gaps) de desempenho dos pesquisados, em comparação com o padrão de bom desempenho definido pela empresa. A pesquisadora solicitou a cada gestor que atribuísse grau de importância a cada item avaliado para o cargo. Os graus variaram de 0 a 3 , conforme os seguintes critérios: 0 - item não é importante para o cargo; 1 - menos importante; 2 - é importante; 3 - muito importante. Posteriormente foram calculadas as médias aritméticas das pontuações obtidas, que serviram como referência para o cálculo da média ponderada das avaliações finais (pesos).

\section{PROCEDIMENTOS}

\subsection{Ações anteriores à coleta de dados}

$>$ A primeira etapa anterior à realização da pesquisa foi a obtenção da aprovação da empresa. Foi solicitada autorização às chefias da redação, explicando-se os objetivos e os procedimentos da coleta de dados. Após o claro entendimento com relação a esses aspectos, acordou-se não divulgar o nome da empresa, preservando a confidencialidade, o que possibilitou o acesso à coleta de dados e a realização da pesquisa.

$>$ Em seguida foi elaborada a descrição dos cargos (anexos 2A e 2B) e realizada a construção das planilhas de avaliação de desempenho para repórter e repórter cinematográfico (anexos 3A e 3B), com base nas descrições referidas anteriormente.

$>$ A etapa seguinte foi a validação das duas planilhas de avaliação, para os cargos de repórter e repórter cinematográfico. 
Para que os instrumentos pudessem ser criticados e se garantisse a imparcialidade, a validação foi realizada em outra unidade da emissora, situada fora da cidade de São Paulo, e a análise do conteúdo das planilhas foi realizada por profissionais - aqui denominados "juízes" - que detinham amplo conhecimento dos dois cargos pesquisados, porém não participariam diretamente da pesquisa. O conteúdo de cada planilha foi validado por seis juízes, ou seja, no total doze juízes participaram dessa etapa de validação (anexo 4).

$>$ Em seguida houve a definição do padrão de desempenho esperado pela empresa para cada um dos cargos separadamente (anexos 5A e 5B), conforme já descrito no anteriormente.

\subsection{Coleta de dados - detalhamento}

Para coletar os dados, foi preciso que a pesquisadora acompanhasse cada etapa do processo e cada um dos sujeitos na aplicação da pesquisa e no momento da avaliação de desempenho com as chefias. A pesquisa foi realizada na redação de jornalismo da emissora, entre o final de novembro de 2006 e o final de janeiro de 2007.

$>$ Entrega dos termos de consentimento informado:

A adesão dos sujeitos foi voluntária, por meio de consulta verbal e da assinatura do termo de consentimento informado. A consulta era realizada pela pesquisadora quando os repórteres e repórteres cinematográficos chegavam à redação e eles foram informados sobre cada etapa da pesquisa, com relação aos testes de stress, e sobre os processos e procedimentos da avaliação de desempenho (anexo 6) .

$>$ Escolha da amostra:

A amostra foi caracterizada pelos sujeitos que manifestarem interesse espontâneo em participar da pesquisa. Com relação a esse item, é importante reiterar o cuidado com as normas éticas, o compromisso com o sigilo profissional e a confidencialidade dos dados obtidos, sem revelar as pessoas, garantindo a proteção dos participantes. Os pesquisados revelavam motivação e interesse espontâneo em tomar parte na pesquisa e o anonimato deles foi respeitado. Após a etapa conclusiva do trabalho, será necessário dar retorno sobre os resultados de stress. Os resultados de desempenho (feedback) foram apresentados no momento da avaliação dos participantes da pesquisa.

$>$ Aplicação dos testes: 
A partir do aceite, os sujeitos preencheram o formulário de caracterização da amostra (anexo 1) e logo após foi aplicado o teste BEPATYA - Behavior Patterns Type A, seguido do teste LSS/VAS - Lista de Sintomas de Stress.

$>$ O momento da avaliação de competência e desempenho ocorreu nas seguintes etapas:

- A pesquisadora informou os sujeitos avaliados sobre os procedimentos da avaliação e solicitou que fizessem a sua auto-avaliação através do instrumento específico (anexo 3A ou 3B). A instrução consistiu em que o sujeito marcasse um " $x$ " no campo correspondente ao nível que melhor identificasse a sua competência e desempenho para cada item de avaliação. Também foi informado que duas chefias avaliariam o sujeito e que haveria uma reunião devolutiva (feedback) com o avaliado, no momento em que se apresentariam os resultados da avaliação.

- No mesmo dia a pesquisadora solicitou às duas chefias imediatas do sujeito avaliado que preenchessem cada qual uma planilha de avaliação separadamente (anexo 3A ou 3B) e que entregassem à pesquisadora. Também foi informado que haveria uma reunião devolutiva com o avaliado, quando se daria retorno sobre a avaliação, em data agendada durante a semana da pesquisa.

$>$ O momento da reunião de avaliação:

- As duas chefias se reuniram com o avaliado para apresentar os resultados da avaliação. A reunião foi conduzida pelas chefias, na sala da redação, com a presença da pesquisadora, cuja atuação foi apenas como observadora, sem interferir no julgamento dos avaliadores. Estes preencheram a planilha de avaliação final, que refletia o consenso entre os avaliadores e o avaliado, e que foi entregue à pesquisadora.

\subsection{Gabaritos para a avaliação de competência e desempenho}

Para cálculo final dos resultados da avaliação de competência e desempenho de cada sujeito avaliado, considerou-se a planilha de avaliação final consensual, resultado da reunião devolutiva entre chefias e sujeito, e o perfil padrão definido pela empresa.

Os procedimentos adotados foram os seguintes:

$1^{\circ}$ - PONTUAÇÃO: cada item avaliado na planilha final foi transformado em valor numérico, sendo atribuído: $\mathrm{NA}=0$ ponto $\mathrm{ED}=1$ ponto; $\mathrm{A}=2$ pontos $; \mathrm{S}=3$ pontos. 
$2^{\circ}$ - MÉDIA PONDERADA: em cada planilha os valores foram multiplicados pelo peso correspondente ao item avaliado, de acordo com o grau de importância definido com base no perfil padrão de desempenho da empresa, e foi realizada a soma. O total foi dividido pela somatória dos pesos e se obteve a média ponderada.

$3^{\circ}$ - RESULTADOS: Os resultados numéricos foram classificados de acordo com a escala de valores abaixo, sendo NA e ED considerados resultados de competência ou desempenho abaixo do esperado, A considerado nível de competência e/ou desempenho adequado e S considerado como alta competência e/ou alto desempenho no cargo (escala abaixo).

\begin{tabular}{|l|}
\hline Escala \\
\hline $\mathrm{NA}=0-0,5$ \\
\hline $\mathrm{ED}=0,6-1,5$ \\
\hline $\mathrm{A}=1,6-2,5$ \\
\hline $\mathrm{S}=>2,6$ \\
\hline
\end{tabular}

\section{AVALIAÇÃO ESTATÍSTICA DOS DADOS}

A apresentação dos dados será dividida em três partes.

\section{PARTE 1 - Resultados das variáveis sócio-demográficas}

Essa primeira parte tem por objetivo possibilitar uma visão ampla da amostra e da pesquisa realizada, para tanto as variáveis sócio-demográficas são analisadas separadamente para cada grupo, R (repórter) e RC (repórter cinematográfico), e para a amostra total (AT). Nessa etapa os resultados serão demonstrados num formato ilustrativo, com tabelas e gráficos demográficos, e analisados quanto à sua significância, utilizando-se para tal o teste estatístico adequado aos níveis de mensuração das variáveis envolvidas:

1- Sexo - prova de Qui-Quadrado

2 - Idade - prova T de Student para amostras independentes

3 - Estado civil - prova de Fisher

4 - Número de filhos - prova T de Student

5 - Grau de escolaridade - prova de Qui-Quadrado

6 - Tempo na empresa atual - prova $T$ de Student para amostras independentes

7 - Tempo total de profissão - prova T de Student para amostras independentes 
8 - Número de horas trabalho/dia - prova T de Student

As tabelas obedecem a uma ordem de apresentação em que, para cada variável, se demonstra o número de pesquisados e as medidas descritivas adequadas (porcentagens, médias e desvios padrão) para os grupos R (repórter) e RC (repórter cinematográfico) e para AT (amostra total), comparando-se os respectivos resultados. A margem de erro adotada foi de $5 \%(\alpha=0,05)$. Apenas onde a análise estatística se mostrar significante para as variáveis quantitativas, será construído um gráfico do tipo error bar dos resultados.

\section{PARTE 2 - Resultados nos Instrumentos}

Nessa parte são descritos todos os resultados dos testes e dos instrumentos utilizados nesta pesquisa, para cada grupo $\mathrm{R}$ e $\mathrm{RC}$ separadamente e para a amostra total. Os resultados variantes dentro de cada variável são demonstrados de forma ilustrativa, graficamente, e são também analisados estatisticamente quanto à sua significância, utilizando-se para tal a prova estatística correspondente:

1 - Comportamento tipo A - prova U de Mann-Whitney

2 - LSS/ VAS (nível de presença de stress, nível de freqüência de stress, nível de intensidade de stress, nível geral de stress, fase de stress) - prova U de Mann-Whitney

3 - Competência - prova U de Mann-Whitney

4 - Desempenho - prova U de Mann-Whitney

Apenas onde a análise estatística se mostrar significante para as variáveis quantitativas, será construído um gráfico do tipo error bar dos resultados.

\section{PARTE 3 - Matrizes de Intercorrelações}

A terceira parte é a mais minuciosa e apresenta matrizes de intercorrelações que demonstram as correlações significantes entre variáveis e fatores investigados nesta pesquisa. Foram organizadas três matrizes: a primeira matriz intercorrelaciona todas as variáveis pesquisadas no grupo R, a segunda refere-se à intercorrelação de todas as variáveis do grupo RC e a terceira matriz cruza as variáveis da amostra total.

As medidas utilizadas para medir as correlações entre as variáveis foram as seguintes:

- Coeficiente de correlação "r "de Pearson - utilizado para duas variáveis quantitativas;

- Coeficiente " $\varphi$ " - utilizado para duas variáveis nominais dicotômicas; 
- Coeficiente "v" de Cramér - utilizado para uma variável nominal dicotômica e outra nominal não dicotômica;

- "T de Student" - para uma variável nominal dicotômica e outra quantitativa;

- "F" de Snedecor - para uma variável nominal não dicotômica e outra quantitativa.

As matrizes gerais com o cruzamento de todas as variáveis dos grupos R, RC e AT (significantes e não significantes) estão nos anexos 7,8 e 9 .

\section{PARTE 4 - Formação de Clusters}

A parte 4 demonstra a sugestão da formação de clusters, de acordo com o agrupamento de resultados comuns da amostra total, levando-se em conta as avaliações dos testes Bepatya NBTA (total e fatores), LSS/VAS (nível de presença, frequiência, intensidade, nível geral e fases), níveis de competência e desempenho. 


\section{RESULTADOS}


RESULTADOS - PARTE 1 RESULTADOS DAS VARIÁVEIS SÓCIO-DEMOGRÁFICAS 


\section{PARTE 1 - RESULTADOS DAS VARIÁVEIS SÓCIO-DEMOGRÁFICAS}

A seguir são apresentadas as variáveis sócio-demográficas pesquisadas que identificam a amostra (sexo, idade, estado civil, número de filhos, grau de escolaridade, formação acadêmica, tempo da empresa atual, tempo total de profissão, número de horas de trabalho/dia) e os resultados variantes dentro de cada variável.

Tais resultados são demonstrados em formato de tabelas e gráficos demográficos, conforme mencionados no capítulo anterior, e analisados quanto à sua significância, utilizandose para tal o teste estatístico adequado aos níveis de mensuração das variáveis envolvidas: a prova de Qui-quadrado (sexo, escolaridade), a prova estatística T de Student (idade, número de filhos, tempo na empresa atual, tempo total de profissão, número de horas de trabalho/dia) e prova de Fisher (estado civil).

As tabelas obedecem a uma ordem de apresentação em que, para cada variável, se demonstra o número de pesquisados e as medidas descritivas adequadas (porcentagens, médias e desvios padrão) para os grupos R (repórter) e RC (repórter cinematográfico) e para AT (amostra total), comparando-se os respectivos resultados. A margem de erro adotada foi de $5 \%(\alpha=0,05)$. Apenas onde a análise estatística se mostrar significante para as variáveis quantitativas, será construído um gráfico do tipo error bar dos resultados. 


\section{SEXO}

A tabela 1 apresenta a distribuição dos sujeitos de acordo com a variável "sexo".

Tabela 1: Distribuição dos sujeitos quanto à variável SEXO, considerando os grupos R e RC.

\begin{tabular}{lccc}
\hline & Repórter & $\begin{array}{c}\text { Repórter } \\
\text { cinematográfico } \\
\%\end{array}$ & $\begin{array}{c}\text { Amostra } \\
\text { total } \\
\%\end{array}$ \\
\hline Masculino & 55,0 & 90,0 & 72,5 \\
Feminino & 45,0 & 10,0 & 27,5 \\
Total & 100,0 & 100,0 & 100,0 \\
$\mathbf{N}$ & $(20)$ & $(20)$ & $(40)$ \\
\hline
\end{tabular}

Observa-se que a distribuição quanto ao sexo no grupo de repórteres é equilibrada, 55\% de homens e $45 \%$ de mulheres, enquanto no grupo de repórter cinematográfico a diferença é bem acentuada, $90 \%$ e $10 \%$ respectivamente. Considerando-se a amostra total (40), verifica-se que a maioria dos sujeitos é do sexo masculino $(72,5 \%)$ e que a participação feminina é menor, $27,5 \%$.

A representação gráfica é demonstrada nas figuras 1, 2 e 3 abaixo:

Figura 1 e 2 . Distribuição de cargos por SEXO, para R e RC.

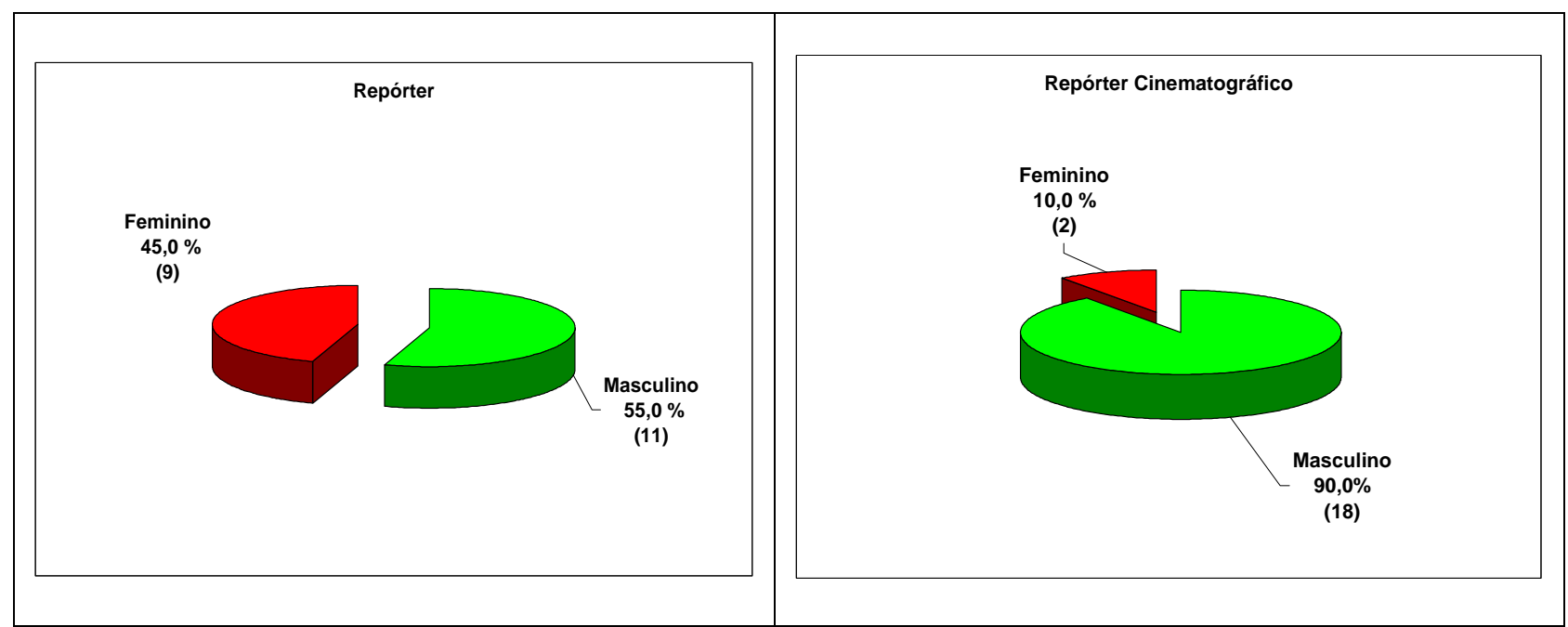




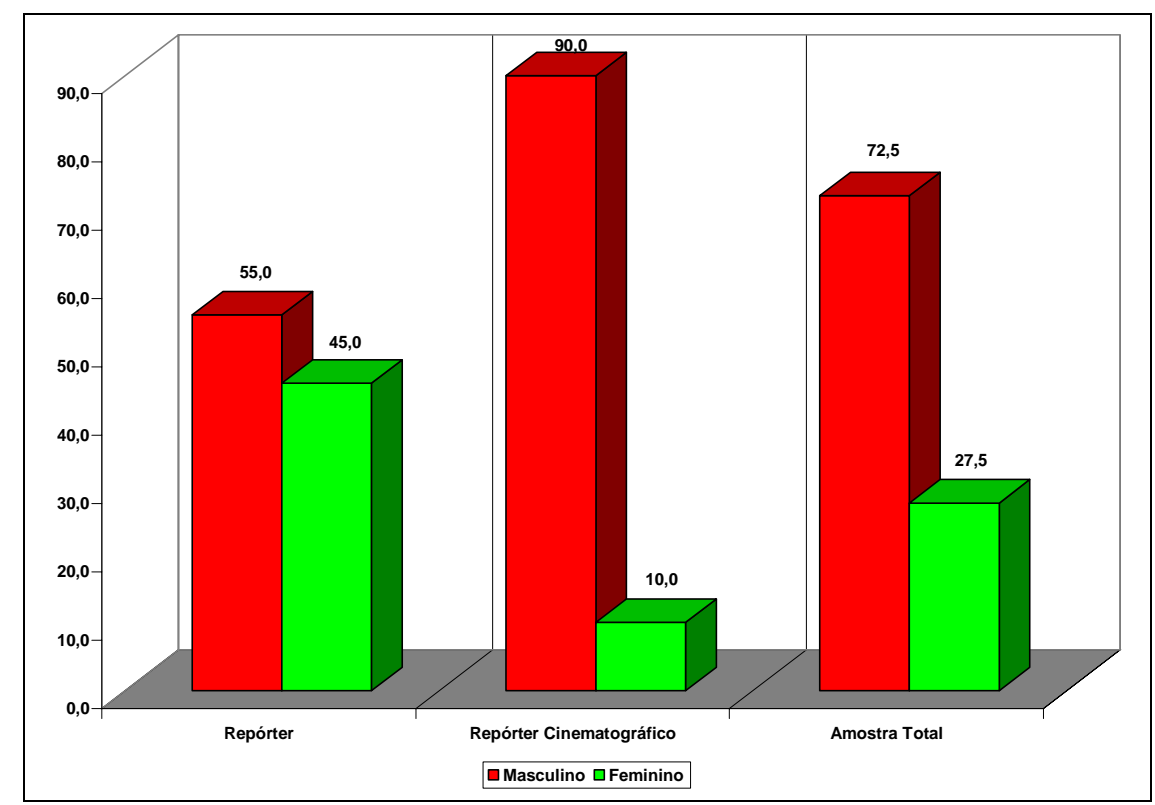

Figura 3: Distribuição por SEXO nos Grupos e Amostra Total (1).

A tabela 2 a seguir apresenta a análise estatística da variável "sexo".

Tabela 2: Análise de significância da distribuição dos sujeitos quanto à variável "sexo", considerando a amostra total de R e RC.

G $\quad \chi^{2} \quad$ p $\quad$ Conclusão

\begin{tabular}{llll}
\hline R/RC & 6,14 & 0,013 & significante
\end{tabular}

Observa-se na tabela 2 que a menor presença do gênero feminino no grupo $\mathrm{R}$ e no grupo $\mathrm{RC}$ estabelece uma diferença significante entre os dois grupos.

(1) conforme mencionado no sub-capítulo 5 (avaliação estatística dos dados), o gráfico (error bar) será construído apenas para as variáveis significantes e quantitativas. 


\section{IDADE}

Na tabela 3 a seguir, apresentam-se as médias e o desvio padrão para a variável "idade".

Tabela 3: Média e desvio padrão para a variável "idade", considerando os grupos R e RC e AT.

\begin{tabular}{lccc}
\hline \multicolumn{1}{c}{ Idade } & Repórter & $\begin{array}{c}\text { Repórter } \\
\text { cinematográfico }\end{array}$ & $\begin{array}{c}\text { Amostra } \\
\text { total }\end{array}$ \\
\hline Média & 36,5 & 40,7 & 38,6 \\
Desvio padrão & 9,4 & 8,9 & 9,3 \\
N & 20 & 20 & 40 \\
\hline
\end{tabular}

Apesar de o grupo R ser mais jovem (média = 36,5) do que o grupo RC (média =40,7), verificase que as idades dos sujeitos variam mais no grupo $\mathrm{R}(9,4)$ do que no grupo $\mathrm{RC}(8,9)$. $\mathrm{O}$ grupo de repórteres apresenta idade que varia de 24 a 60 anos, enquanto no grupo de repórteres cinematográficos a idade varia de 22 a 52 anos. A média de idade da amostra total é de 38,6 anos.

A figura 4 abaixo ilustra a comparação da distribuição por média da variável “idade”.

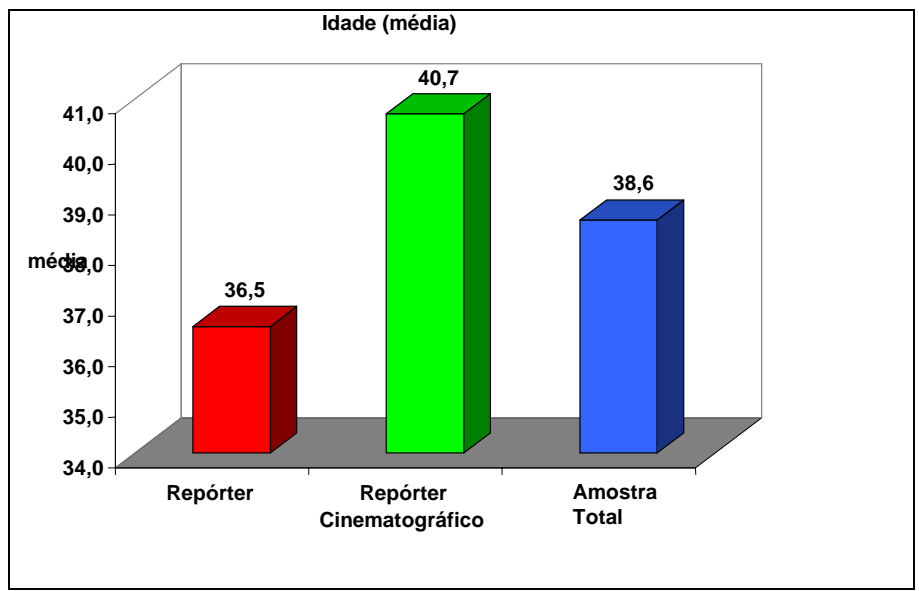

Figura 4. Comparativo das médias de idade entre R, RC e AT. 
A seguir é demonstrado o resultado da análise estatística.

Tabela 4: Análise de significância da distribuição dos sujeitos quanto à variável "idade", considerando a amostra total de R e RC.

\begin{tabular}{llll}
\hline G & $\mathbf{t}$ & $\mathbf{p}$ & Conclusão \\
\hline R/RC & $-1,45$ & 0,155 & NS (2) \\
\hline
\end{tabular}

Como observado na tabela 4 , apesar de as idades dos sujeitos variarem mais no grupo $\mathrm{R}(9,4)$ do que no grupo RC $(8,9)$, a diferença entre as médias não é significante estatisticamente.

(2) Será utilizada a sigla NS toda vez que o resultado da análise for considerado estatisticamente não significante. 


\section{ESTADO CIVIL}

Para a análise da variável "estado civil", considerou-se dois subgrupos distintos: o subgrupo dos solteiros e separados e o subgrupo dos casados e dos que vivem maritalmente.

A tabela 5 a seguir demonstra a distribuição dos sujeitos entre os dois subgrupos.

Tabela 5: Distribuição dos sujeitos conforme o "estado civil", considerando os grupos R e RC e amostra total.

\begin{tabular}{lccc}
\hline Estado civil & Repórter & $\begin{array}{c}\text { Repórter } \\
\text { cinematográfico }\end{array}$ & $\begin{array}{c}\text { Amostra } \\
\text { total }\end{array}$ \\
& $\%$ & $\%$ & $\%$ \\
Solteiros + separados & 25,0 & 15,0 & 20,0 \\
Casados + vivem maritalmente & 75,0 & 85,0 & 80,0 \\
Total & 100,0 & 100,0 & 100,0 \\
N & $(20)$ & $(20)$ & $(40)$ \\
\hline
\end{tabular}

Verifica-se que nos dois grupos ( $\mathrm{R}$ e $\mathrm{RC}$ há um percentual elevado de profissionais casados e que vivem maritalmente (média 80\%)).

A figura 5 abaixo ilustra essa distribuição.

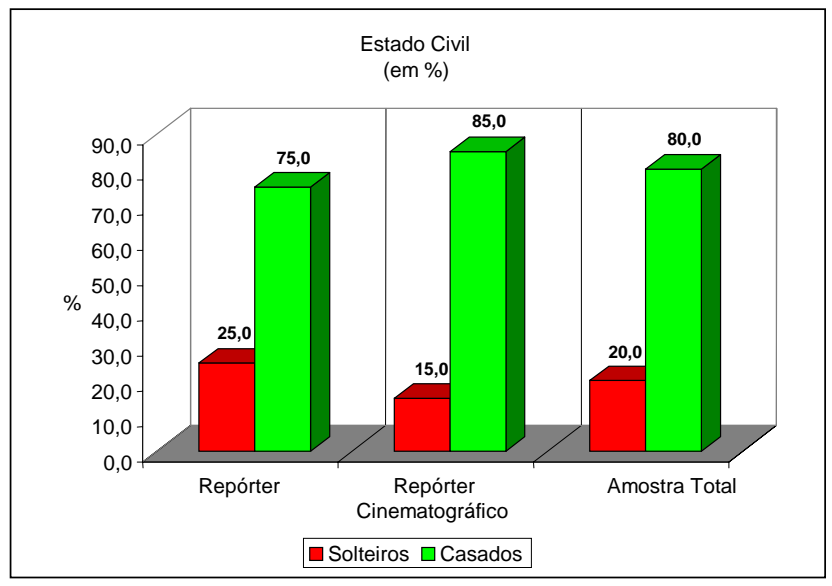

Figura 5. Distribuição dos sujeitos quanto à variável "estado civil", nos dois grupos e na amostra total. 
Na tabela 6, a seguir, é apresentado o resultado estatístico desses dados.

Tabela 6: Análise de significância da distribuição dos sujeitos quanto à variável "estado civil", considerando a amostra total de R e RC.

\begin{tabular}{llll}
\hline G & Teste exato de Fisher & p & Conclusão \\
\hline R/RC & & 0,347 & NS \\
\hline
\end{tabular}

Como podemos verificar na tabela acima, o estado civil não produz diferença significante entre os dois grupos. 


\section{NÚMERO DE FILHOS}

A tabela 7 demonstra a média e o desvio padrão para a variável "número de filhos"

Tabela 7: Média e desvio padrão obtidos quanto à variável "número de filhos", considerando os grupos R e RC e a amostra total.

\begin{tabular}{lccc}
\hline Número de filhos & Repórter & $\begin{array}{c}\text { Repórter } \\
\text { cinematográfico }\end{array}$ & $\begin{array}{c}\text { Amostra } \\
\text { total }\end{array}$ \\
\hline Média & 0,8 & 1,4 & 1,1 \\
Desvio padrão & 1,01 & 0,88 & 0,98 \\
N & $(20)$ & $(20)$ & $(40)$ \\
\hline
\end{tabular}

Observa-se na tabela 7 que a média de filhos do grupo R é menor $(0,8)$ do que a média de filhos do grupo RC $(1,4)$. Há maior variabilidade quanto ao número de filhos no grupo $\mathrm{R}(1,01)$ do que no grupo RC $(0,88)$. Na amostra total, a média do número de filhos é de 1,1 .

Na tabela 8 abaixo é demonstrada a distribuição do número de filhos nos grupos $\mathrm{R}$ e $\mathrm{RC}$ e na amostra total (em \%).

Tabela 8. Demonstrativo dos sujeitos quanto à variável "número de filhos", nos dois grupos e na amostra total.

\begin{tabular}{lccc}
\hline \multicolumn{1}{c}{ Filhos } & $\begin{array}{c}\text { Repórter } \\
\%\end{array}$ & $\begin{array}{c}\text { Repórter } \\
\text { cinematográfico } \\
\%\end{array}$ & $\begin{array}{c}\text { Amostra total } \\
\%\end{array}$ \\
\hline Nenhum & 55,0 & 20,0 & 37,5 \\
$\mathbf{1}$ filho & 15,0 & 25,0 & 20,0 \\
$\mathbf{2}$ filhos & 25,0 & 50,0 & 37,5 \\
$\mathbf{3}$ filhos & 5,0 & 5,0 & 5,0 \\
Total & 100,0 & 100,0 & 100,0 \\
$\mathbf{N}$ & $(20)$ & $(20)$ & $(40)$ \\
\hline
\end{tabular}

Verifica-se na tabela 8 que, no grupo R, 55 \% não têm filhos e $45 \%$ têm de 1 a 3 filhos, enquanto no grupo RC $20 \%$ não têm filhos e $80 \%$ têm de 1 a 3 filhos. Na amostra total, 37,5 \% não têm filhos e $62,5 \%$ têm de 1 a 3 filhos.

Abaixo a ilustração desses dados. 


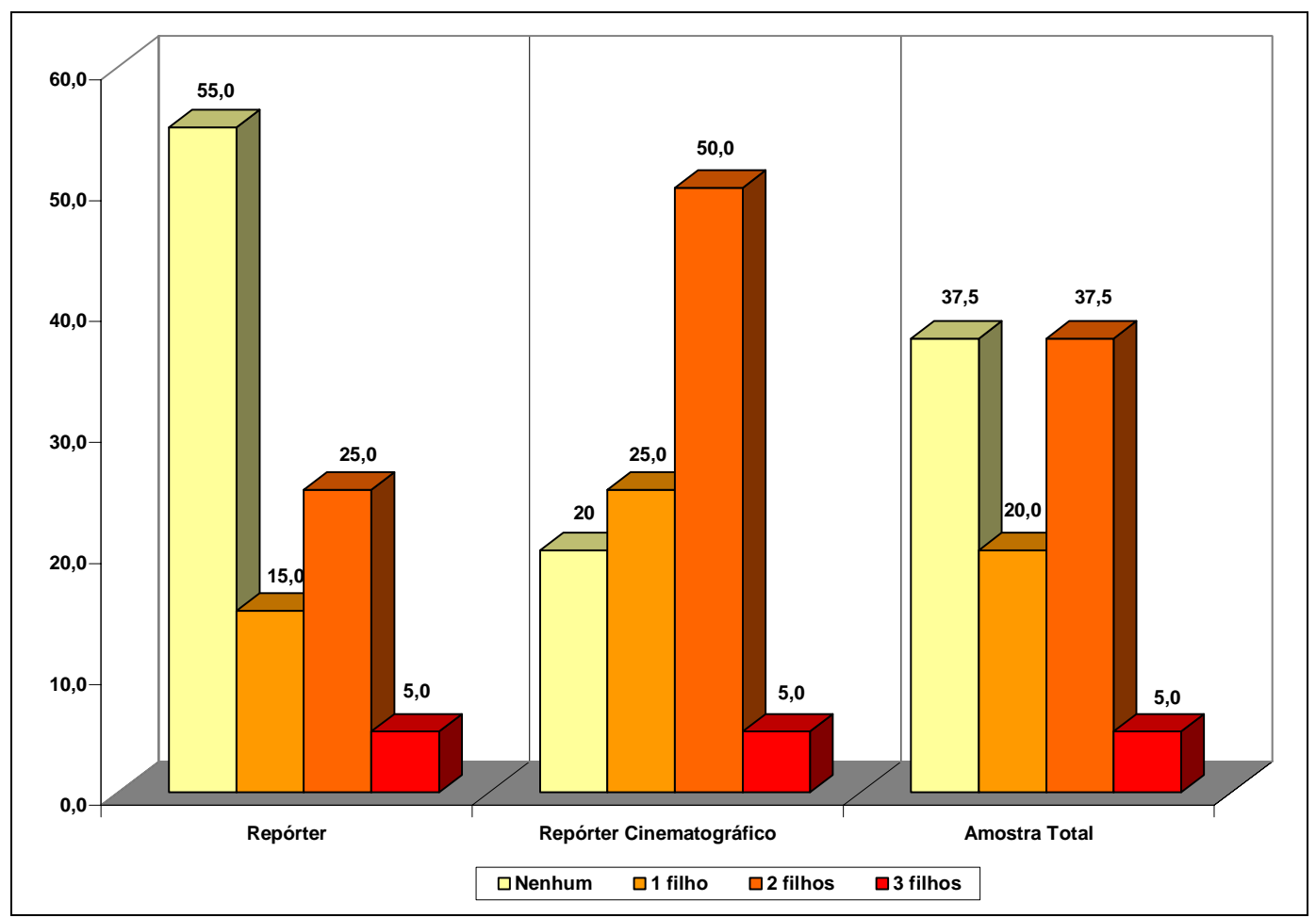

Figura 6. Distribuição dos sujeitos quanto à variável "número de filhos", nos dois grupos e na amostra total.

Observam-se na Figura 7 as médias entre os grupos R $(0,8)$ e RC $(1,4)$.

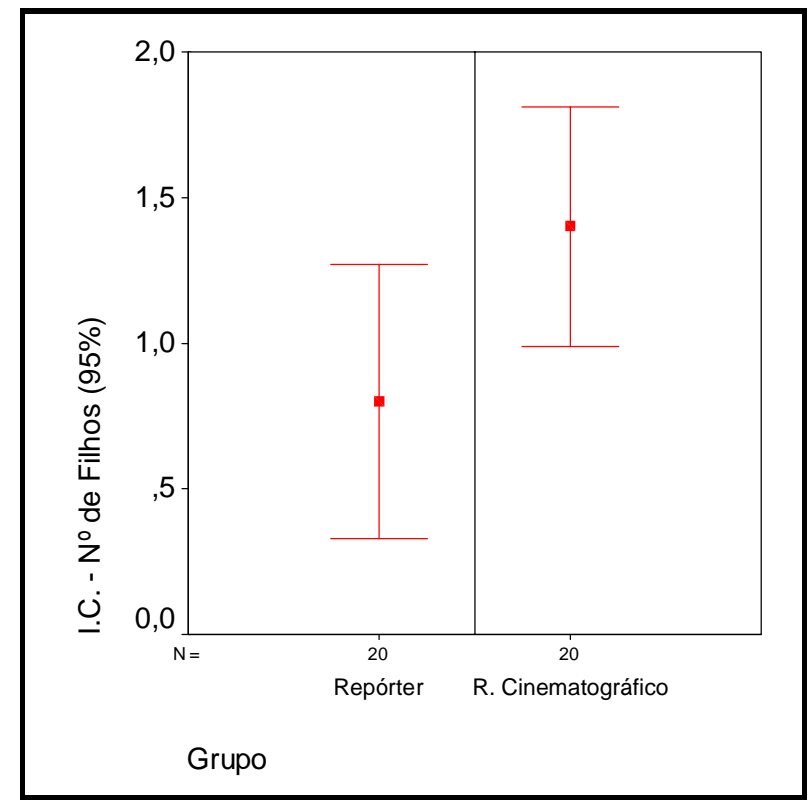

Figura 7. Gráfico "Error Bar" - Comparativo das médias e desvio padrão da variável "número de filhos". 
O gráfico de error bar indica o intervalo de confiança (IC) e demonstra que há 95\% de probabilidade de a população estudada estar contida nessa média, e 5\% de margem de erro, o que significa que existem $95 \%$ de probabilidade desse intervalo conter a média da população estudada. Como graficamente as barras não estão interseccionadas, observa-se que a diferença é estatisticamente significante.

A seguir é apresentada, na tabela 9, a análise estatística dos dois grupos quanto à variável estudada.

Tabela 9: Análise de significância da distribuição dos sujeitos quanto à variável "número de filhos", considerando a amostra total de R e RC.

\begin{tabular}{llll}
\hline G & $\mathbf{t}$ & $\mathbf{p}$ & Conclusão \\
\hline R/RC & $-2,06$ & 0,05 & significante \\
\hline
\end{tabular}

Conforme se pode constatar na tabela acima, há uma diferença significante entre os dois grupos quanto ao número de filhos. 


\section{GRAU DE ESCOLARIDADE}

Para fins de análise dos resultados, foram considerados dois subgrupos quanto ao grau de escolaridade: um subgrupo de sujeitos com $2^{\circ}$ grau completo e superior incompleto e outro subgrupo de sujeitos com grau de escolaridade superior e pós-graduação.

A tabela 10 demonstra a distribuição dos grupos $\mathrm{R}$ e RC e da amostra total quanto à variável "grau de escolaridade".

Tabela 10: Distribuição da variável "grau de escolaridade", considerando os grupos R e RC e a amostra total.

\begin{tabular}{|c|c|c|c|}
\hline Escolaridade & $\begin{array}{c}\text { Repórter } \\
\%\end{array}$ & $\begin{array}{c}\text { Repórter } \\
\text { cinematográfico } \\
\%\end{array}$ & $\begin{array}{c}\text { Amostra } \\
\text { total } \\
\%\end{array}$ \\
\hline $2^{\circ}$ grau + superior incompleto & 0,0 & 70,0 & 35,0 \\
\hline Superior + pós-graduação & 100,0 & 30,0 & 65,0 \\
\hline Total & 100,0 & 100,0 & 100,0 \\
\hline $\mathbf{N}$ & $(20)$ & (20) & $(40)$ \\
\hline
\end{tabular}

Verifica-se na tabela 10 que a distribuição do grau de escolaridade nos grupos $\mathrm{R}$ e RC é heterogênea, na medida em que todo o grupo R revela grau de escolaridade superior ou pósgraduação, enquanto no grupo RC apenas $30 \%$ concluíram o curso superior e $70 \%$ têm $2^{\circ}$ grau completo ou superior incompleto.

Constata-se que $65 \%$ dos sujeitos pesquisados têm no mínimo o grau de escolaridade superior completo, considerando-se a amostra total (40), e 35\% não têm essa condição.

A figura 8 demonstra a distribuição. 


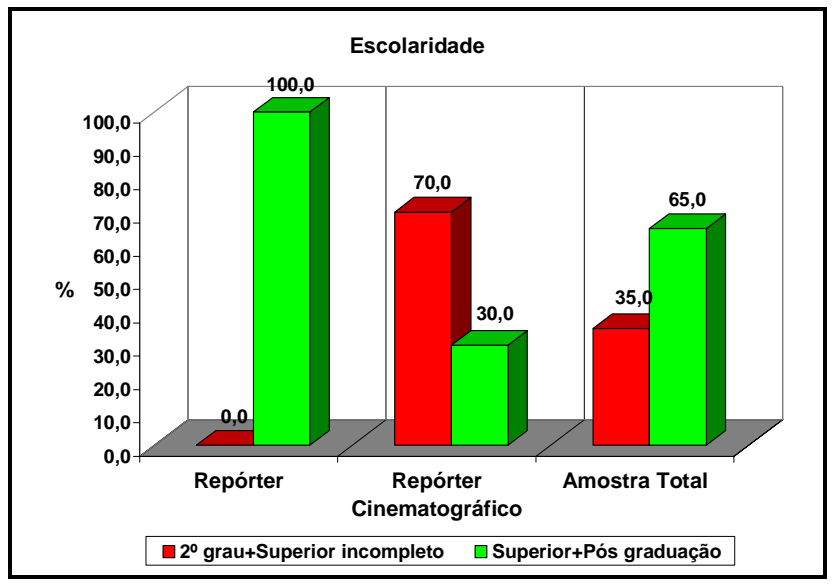

Figura 8. Demonstrativo dos sujeitos quanto ao grau de escolaridade, nos dois grupos e na amostra total.

A seguir é apresentada a análise estatística desses dados, na tabela 11 (1).

Tabela 11: Análise de significância da distribuição dos sujeitos quanto à variável "grau de escolaridade", considerando a amostra total de R e RC.

\begin{tabular}{llll}
\hline G & $\chi^{2}$ & p & Conclusão \\
\hline R/RC & 21,538 & $\mathbf{0 , 0 0 0}$ & significante \\
\hline
\end{tabular}

Conforme a tabela acima, o grau de escolaridade indica uma diferença significante entre os grupos R e RC.

(1) conforme mencionado no sub-capítulo 5 (avaliação estatística dos dados), o gráfico (error bar) será construído apenas para as variáveis significantes e quantitativas. 


\section{FORMAÇÃO ACADÊMICA}

A tabela 12 demonstra a distribuição dos sujeitos dos grupos R, RC e AT por formação acadêmica.

Tabela 12. Distribuição dos grupos R, RC e AT quanto à variável "formação acadêmica".

\begin{tabular}{lccc}
\hline Formação acadêmica & $\begin{array}{c}\text { Repórter } \\
\%\end{array}$ & $\begin{array}{c}\text { Repórter } \\
\text { cinematográfico } \\
\%\end{array}$ & $\begin{array}{c}\text { Amostra } \\
\text { total } \\
\%\end{array}$ \\
\hline Jornalismo & 95,0 & 83,3 & 90,6 \\
Rádio e TV e outras & 5,0 & 16,7 & 9,4 \\
Total & 100,0 & 100,0 & 100,0 \\
$\mathbf{N}$ & $(20)$ & $(12)^{*}$ & $(32)$ \\
\hline * 8 Repórteres Cinematográficos não possuem formação acadêmica, mas apenas $2^{\circ}$ grau completo.
\end{tabular}

A figura 9 demonstra a distribuição da variável "formação acadêmica".

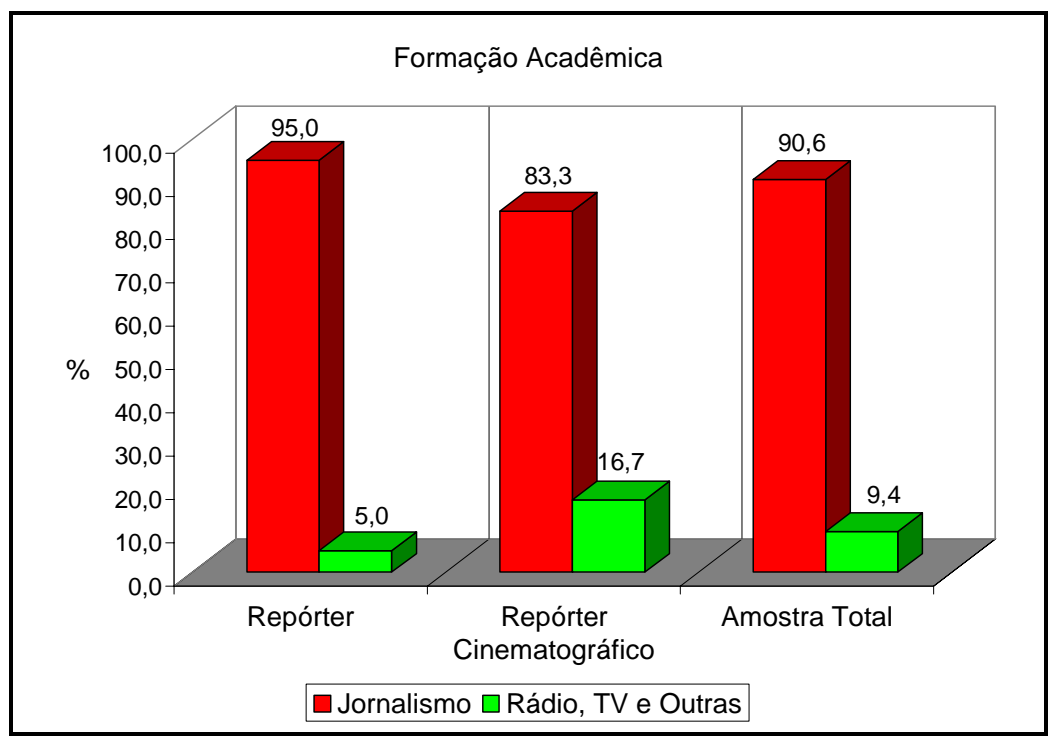

Figura 9. Demonstrativo da distribuição da variável "formação acadêmica" nos dois grupos e na amostra total.

Nos dois grupos a formação acadêmica predominante é o jornalismo (95\% dos repórteres e 83,3\% dos repórteres cinematográficos). 
A seguir é apresentada a análise estatística.

Tabela 13. Análise de significância da AT para a variável "formação acadêmica".

\begin{tabular}{llll}
\hline G & $\chi^{2}$ & p & Conclusão \\
\hline R/RC & 1,202 & 0,273 & NS \\
\hline
\end{tabular}

Verifica-se na tabela 13 que a diferença entre os grupos R e RC não é estatisticamente significante. 


\section{TEMPO NA EMPRESA ATUAL}

O tempo na empresa atual varia no grupo $\mathrm{R}$ de menos de 1 ano a 27 anos e no grupo $\mathrm{RC}$, de menos de 1 ano a 36 anos. A tabela 14 demonstra a média e o desvio padrão da variável "tempo na empresa atual".

Tabela 14: Média e desvio padrão obtidos para a variável "tempo na empresa atual", considerando os grupos R e $\mathrm{RC}$ e a amostra total.

\begin{tabular}{lccc}
\hline $\begin{array}{c}\text { Tempo na empresa } \\
\text { atual }\end{array}$ & Repórter & $\begin{array}{c}\text { Repórter } \\
\text { cinematográfico }\end{array}$ & $\begin{array}{c}\text { Amostra } \\
\text { total }\end{array}$ \\
\hline Média & 6,1 & 13,00 & 9,55 \\
Desvio padrão & 6,32 & 13,05 & 10,71 \\
N & $(20)$ & $(20)$ & $(40)$ \\
\hline
\end{tabular}

Observa-se que a média de tempo dos sujeitos na empresa atual no grupo RC é muito superior (13 anos) à do grupo $\mathrm{R}$ (6,1 anos), o que está ilustrado na figura a seguir. A média de tempo da amostra total é elevada $(9,55$ anos).

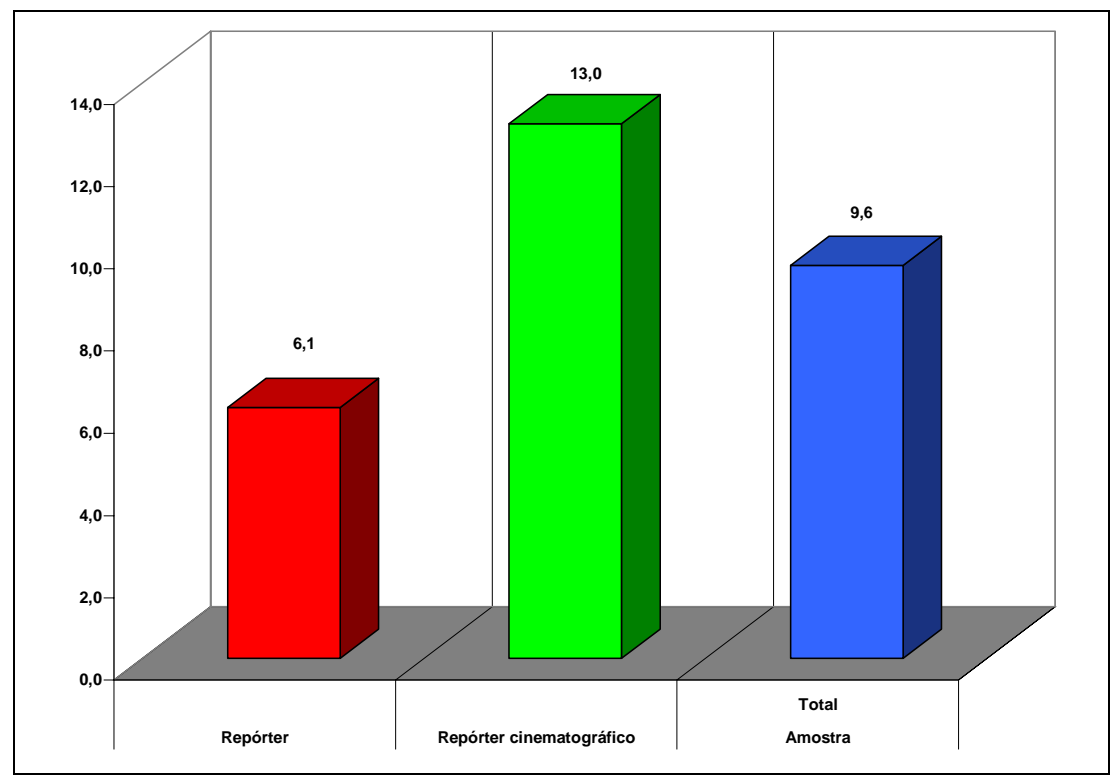

Figura 10. Demonstrativo da distribuição das médias da variável "formação acadêmica" nos dois grupos e na amostra total.

Verifica-se na figura 11, outra representação das médias e vê-se que a variabilidade do tempo na empresa atual é maior no grupo RC $(13,05)$ do que no grupo $\mathrm{R}(6,32)$. 


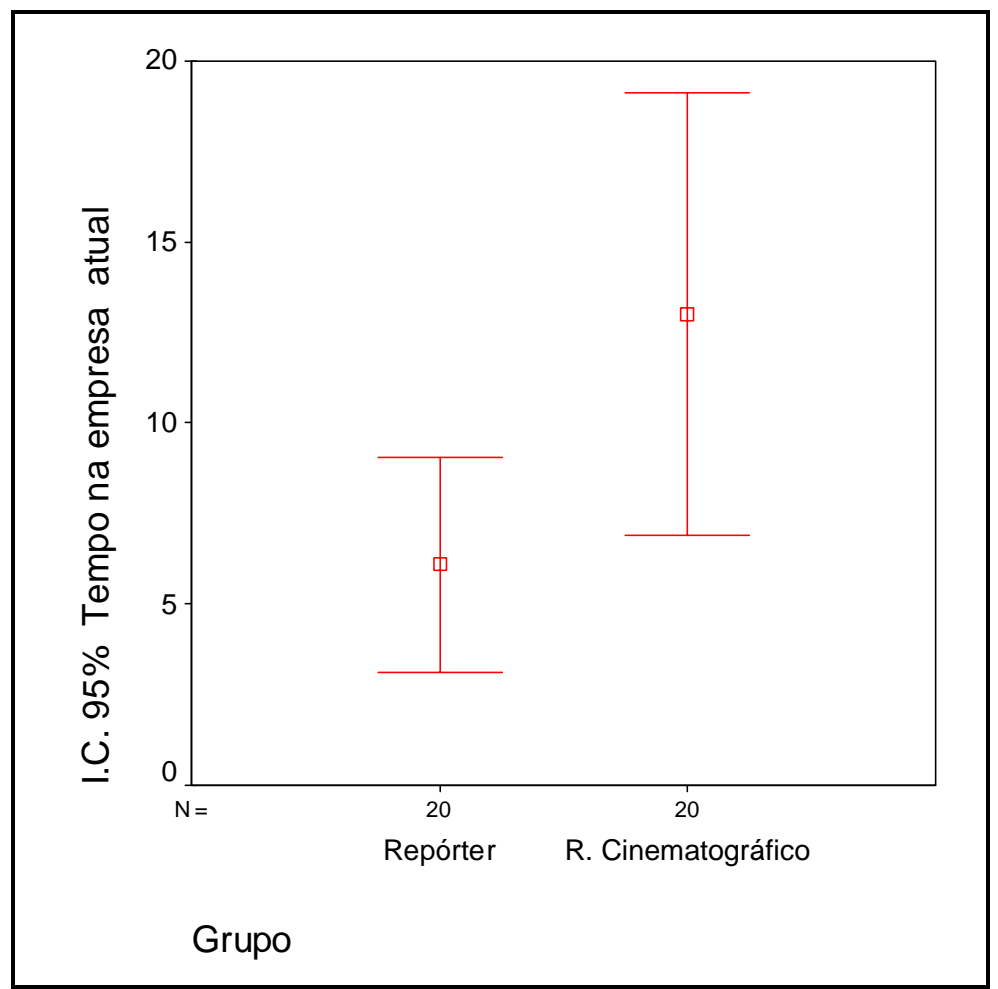

Figura 11. Gráfico "Error Bar" - Comparativo das médias e desvio padrão da variável "tempo na empresa atual" para os dois grupos.

Como graficamente as barras não estão interseccionadas, observa-se que a diferença é estatisticamente significante.

A seguir é apresentada a análise estatística desses dados, na tabela 15.

Tabela 15: Análise de significância da distribuição dos sujeitos quanto à variável "tempo na empresa atual", considerando a amostra total de R e RC.

\begin{tabular}{llll}
\hline G & $\mathbf{t}$ & $\mathbf{p}$ & Conclusão \\
\hline R/RC & $\mathbf{2 , 1 3}$ & $\mathbf{0 , 0 4 2}$ & significante \\
\hline
\end{tabular}

Conforme a tabela acima, observamos que há diferença significante entre os dois grupos quanto ao tempo na empresa atual. 


\section{TEMPO TOTAL DE PROFISSÃO}

O tempo total de profissão dos sujeitos no grupo R varia de 3 a 40 anos e no grupo RC, de 5 a 35 anos. A tabela 16 demonstra a média e o desvio padrão da variável "tempo total de profissão".

Tabela 16: Média e desvio padrão obtidos para a variável "tempo total de profissão", considerando os grupos R e $\mathrm{RC}$ e a amostra total.

\begin{tabular}{lccc}
\hline $\begin{array}{l}\text { Tempo total de profissão } \\
\text { (em anos) }\end{array}$ & Repórter & $\begin{array}{c}\text { Repórter } \\
\text { cinematográfico }\end{array}$ & $\begin{array}{c}\text { Amostra } \\
\text { total }\end{array}$ \\
\hline Média & 14,70 & 19,05 & 16,88 \\
Desvio padrão & 9,95 & 9,47 & 9,84 \\
N & $(20)$ & $(20)$ & $(40)$ \\
\hline
\end{tabular}

Pode-se observar na tabela 16 que há diferença entre as médias de tempo de profissão entre os dois grupos, sendo 14,70 anos no grupo R e 19,05 anos no grupo RC, todavia os valores de desvio padrão são bastante próximos. A AT apresenta elevada média de tempo total de profissão (16,88 anos).

Verifica-se na figura 12 que a média do tempo de profissão é maior no grupo $\operatorname{RC}(19,05)$ do que no grupo $\mathrm{R}(14,70)$.

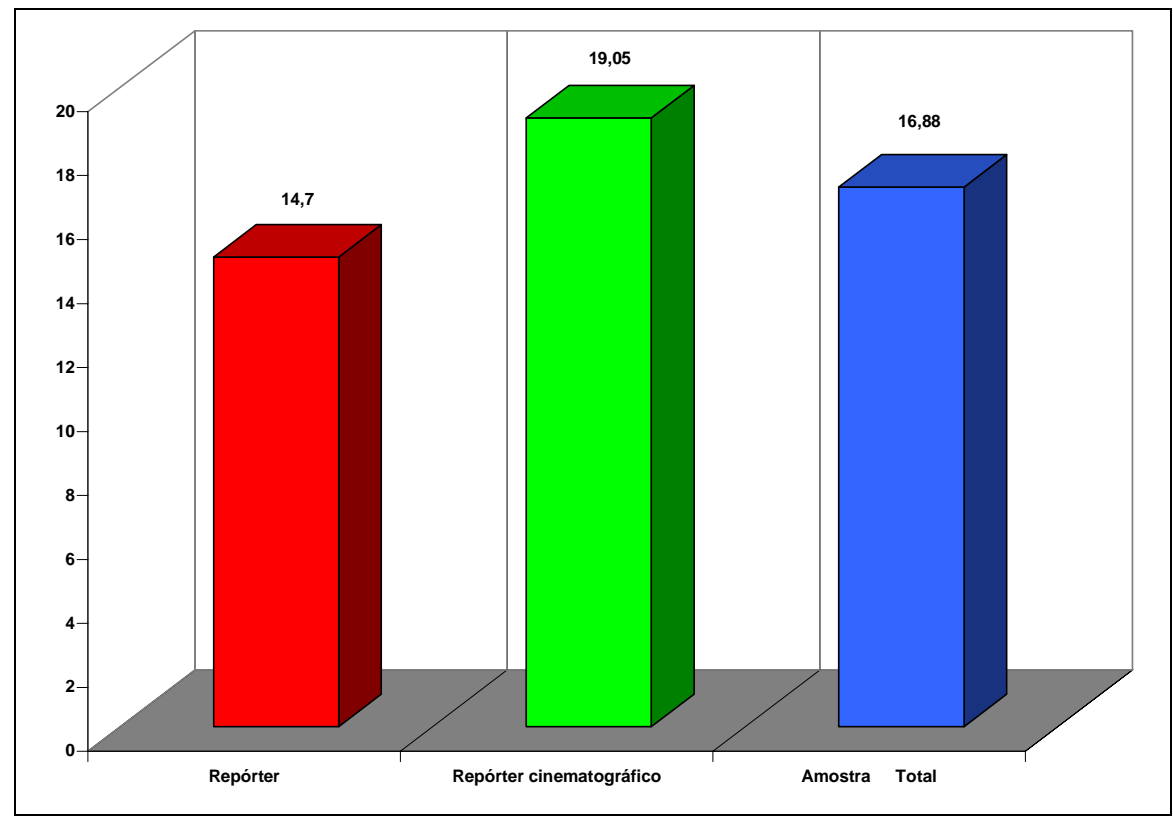

Figura 12. Distribuição das médias para a variável "tempo total de profissão" nos grupos e AT. 
A seguir é apresentada a análise estatística desses dados, na tabela 17.

Tabela 17: Análise de significância da distribuição dos sujeitos quanto à variável "tempo total de profissão", considerando a amostra total de R e RC.

\begin{tabular}{llll}
\hline G & $\mathbf{t}$ & $\mathbf{p}$ & Conclusão \\
\hline R/RC & $-1,42$ & 0,165 & NS \\
\hline
\end{tabular}

Verifica-se na tabela acima que o tempo total de profissão do grupo $\mathrm{R}$ é menor do que o do grupo RC e que não existe diferença significante entre os dois grupos. 


\section{NÚMERO DE HORAS DE TRABALHO/DIA}

A tabela 18 demonstra a média e o desvio padrão da variável "número de horas de trabalho/dia".

Tabela 18: Média e desvio padrão obtidos para a variável "número de horas de trabalho/dia", considerando os grupos R e RC e a amostra total.

\begin{tabular}{lccc}
\hline $\begin{array}{c}\text { Número de horas de } \\
\text { trabalho por dia }\end{array}$ & Repórter & $\begin{array}{c}\text { Repórter } \\
\text { cinematográfico }\end{array}$ & $\begin{array}{c}\text { Amostra } \\
\text { total }\end{array}$ \\
\hline Média & 8,80 & 7,58 & 8,21 \\
Desvio padrão & 1,15 & 1,07 & 1,26 \\
$\mathbf{N}$ & $(20)$ & $(19)^{*}$ & $(39)$ \\
\hline * Sem Resposta $=1$ & & &
\end{tabular}

Observa-se na tabela 18 que a média de horas trabalhadas no grupo $\mathrm{R}(8,80)$ é maior do que no grupo RC $(7,58)$. A média da AT é de 8,21 horas, o que representa uma média próxima à jornada padrão de 8 horas de trabalho/dia.

A demonstração gráfica da tabela 19 , a seguir, revela a distribuição do número de horas.

Tabela 19. Distribuição dos sujeitos quanto à variável "número de horas de trabalho/dia" nos dois grupos.

\begin{tabular}{lccc}
\hline $\begin{array}{c}\mathrm{N}^{\circ} \text { de horas de } \\
\text { trabalho/dia }\end{array}$ & $\begin{array}{c}\text { Repórter } \\
\%\end{array}$ & $\begin{array}{c}\text { Repórter } \\
\text { cinematográfico } \\
\%\end{array}$ & $\begin{array}{c}\text { Amostra } \\
\text { total } \\
\%\end{array}$ \\
\hline 7/8 horas & 40,0 & 75,0 & 57,5 \\
9 horas & 30,0 & 10,0 & 15,0 \\
10 horas & 20,0 & 10,0 & 20,0 \\
$>10$ horas & 10,0 & 0,0 & 17,5 \\
Não informou & 0,0 & 5,0 & 2,5 \\
Total & 100,0 & 100,0 & 100,0 \\
$N$ & $(20)$ & $(20)$ & $(40)$ \\
\hline
\end{tabular}

Os valores da tabela 19 revelam que $75 \%$ dos sujeitos do grupo RC trabalham de 7 a 8 horas e que o grupo R tem mais horas de trabalho/dia, informação que também é ilustrada na figura 13 abaixo. 


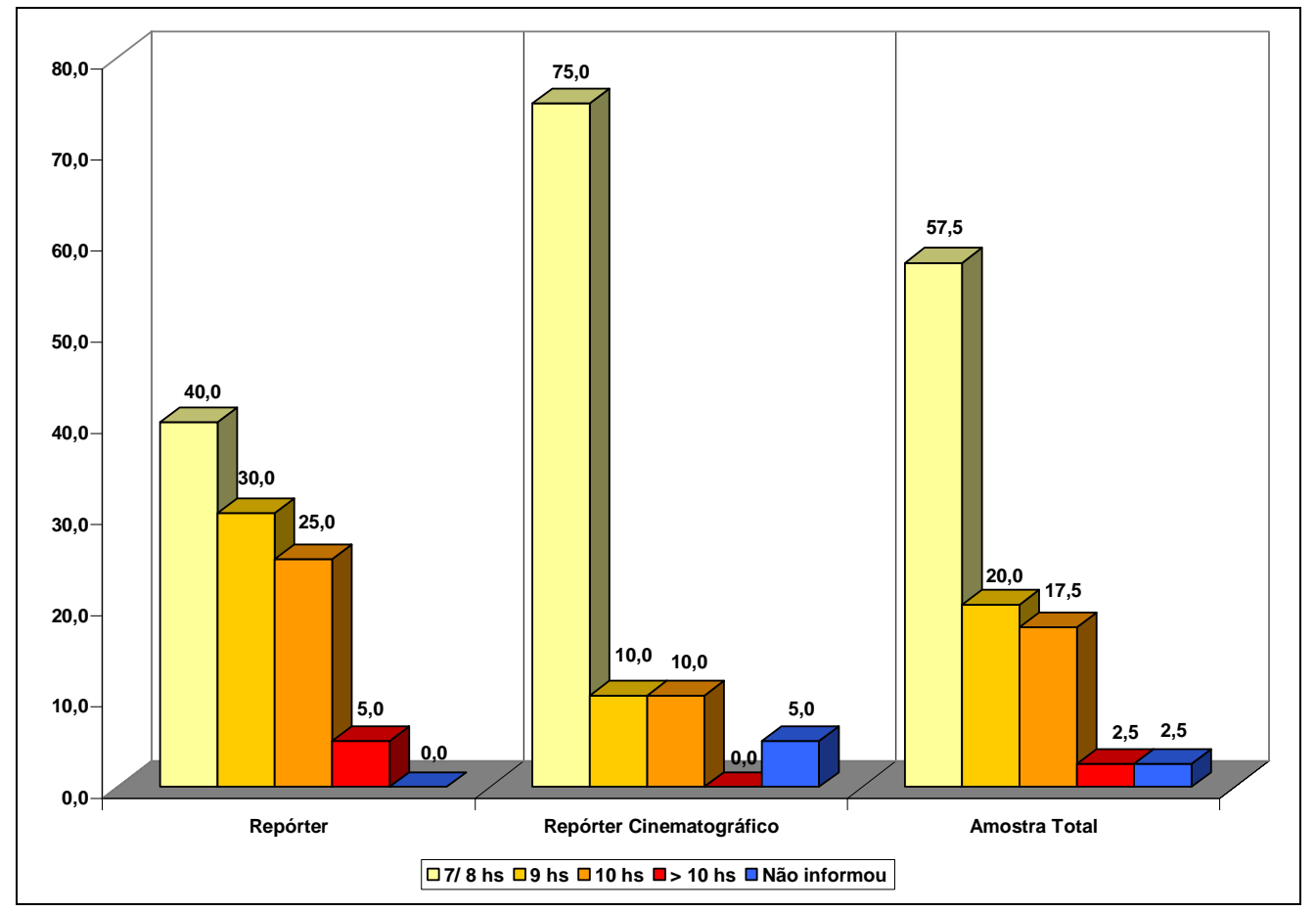

Figura 13. Distribuição do número de horas de trabalho/dia nos dois grupos.

A figura 14 abaixo indica outra representação gráfica das médias.

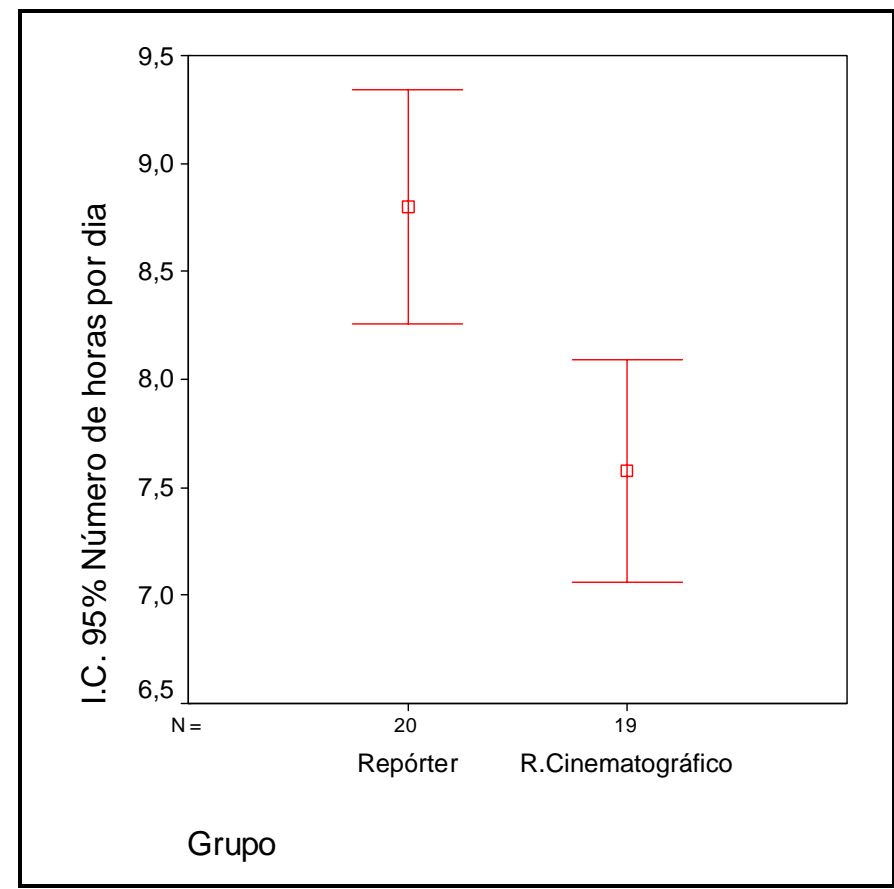

Figura 14. Médias do número de horas de trabalho/dia nos dois grupos. 
Como graficamente as barras não estão interceccionadas, observa-se que a diferença é estatisticamente significante.

A seguir, é apresentada a análise de significância entre os dois grupos.

Tabela 20: Análise de significância da distribuição dos sujeitos quanto à variável "número de horas de trabalho/dia", considerando a amostra total de R e RC.

\begin{tabular}{llll}
\hline G & $\mathbf{t}$ & $\mathbf{p}$ & Conclusão \\
\hline R/RC & $\mathbf{- 3 , 4 3}$ & $\mathbf{0 , 0 0 2}$ & significante \\
\hline
\end{tabular}

Observa-se que o fato de ser maior o número de horas trabalhadas/dia no grupo $\mathrm{R}$ estabelece uma diferença estatisticamente significante entre os dois grupos. 
RESULTADOS - PARTE 2 RESULTADOS DOS INSTRUMENTOS 


\section{PARTE 2 - RESULTADOS DOS INSTRUMENTOS}

A seguir são apresentados os resultados dos instrumentos utilizados na pesquisa nos dois grupos: o teste BEPATYA (Behavior Pattern Type A), que mensura o padrão de comportamento tipo A dos sujeitos pesquisados (nível e fatores); o teste LSS-VAS, que identifica os níveis de sintomas de stress (presença, frequiência, intensidade, nível geral e fases); e os resultados da avaliação de competência (0- NA- não atende, 1-ED- em desenvolvimento, 2- A-atende plenamente e 3-S- supera) e de desempenho profissional (0- NA- não atende, 1-ED- em desenvolvimento, 2- A-atende plenamente e 3-S- supera).

Os resultados variantes dentro de cada variável são demonstrados de forma ilustrativa, graficamente, e são também analisados estatisticamente quanto à sua significância, utilizando-se para tal a prova U de Mann-Whitney (nível de presença de stress, nível de freqüência de stress, nível de intensidade de stress, nível geral de stress, fase de stress, competência, desempenho).

Apenas onde a análise estatística se mostrar significante, será construído um gráfico do tipo error bar dos resultados. 


\section{COMPORTAMENTO TIPO A}

A seguir são apresentados, nas tabelas 21 e 22, os resultados obtidos para a variável "comportamento tipo A".

Tabela 21: Distribuição da variável "comportamento tipo A" nos grupos R e RC e na amostra total (em \%).

\begin{tabular}{lccc}
\hline $\begin{array}{l}\text { Nível geral de } \\
\text { comportamento } \\
\text { tipo A }\end{array}$ & $\begin{array}{c}\text { Repórter } \\
\text { \% }\end{array}$ & $\begin{array}{c}\text { Repórter } \\
\text { cinematográfico } \\
\text { \% }\end{array}$ & $\begin{array}{c}\text { Amostra } \\
\text { total } \\
\%\end{array}$ \\
\hline Baixo & & 0,0 & 0,0 \\
Baixo-médio & 0,0 & 5,0 & 2,5 \\
Médio & 0,0 & 15,0 & 20,0 \\
Alto & 25,0 & 70,0 & 57,5 \\
Altíssimo & 45,0 & 10,0 & 20,0 \\
$\mathbf{N}$ & 30,0 & $(20)$ & $(40)$ \\
\hline
\end{tabular}

Verifica-se na tabela 21 que $75 \%$ do grupo R e $80 \%$ do grupo RC apresentam comportamento tipo A nos níveis alto e altíssimo. A demonstração gráfica da figura 15, a seguir, revela a distribuição desses resultados.

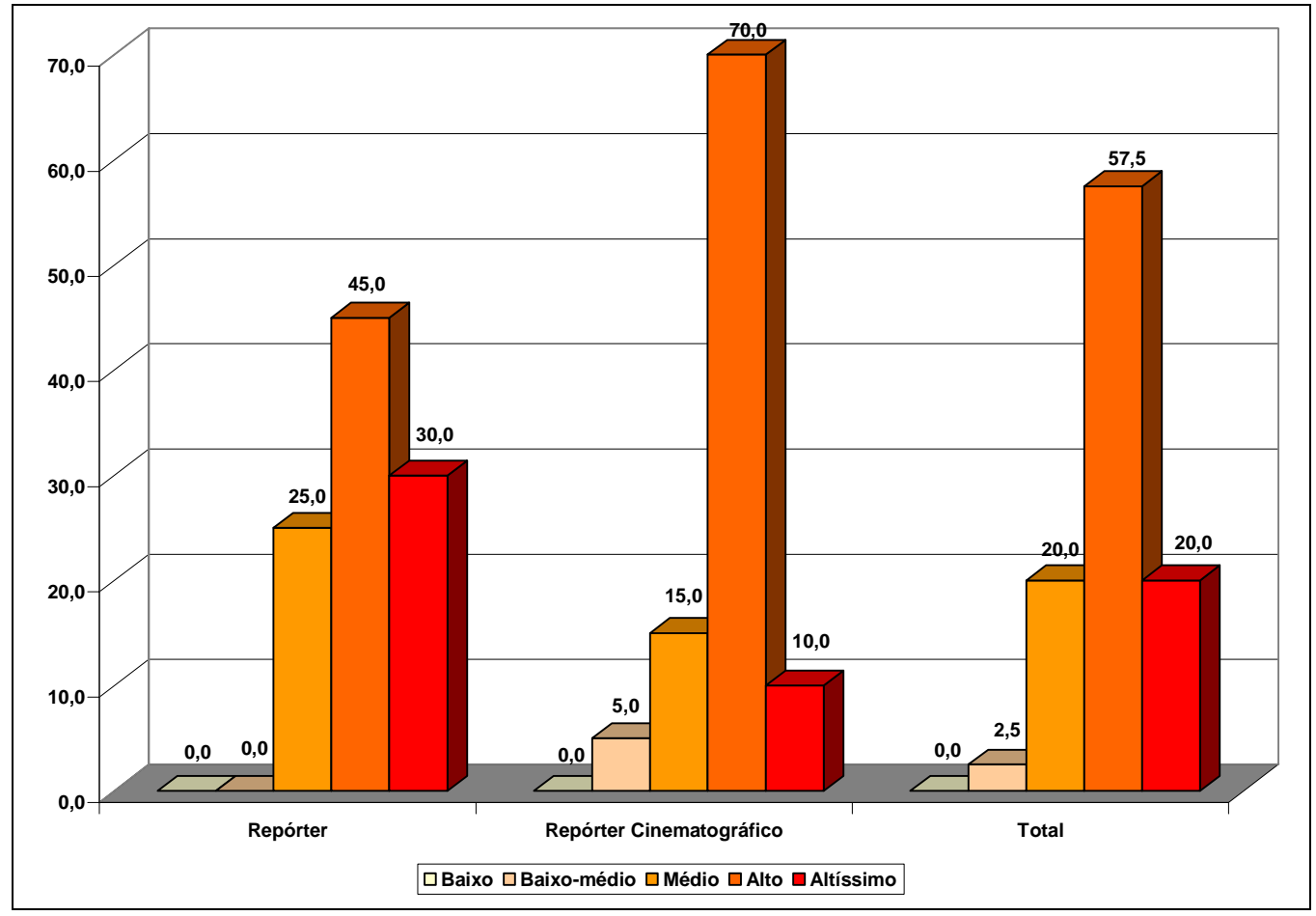

Figura 15. Distribuição do Padrão de Comportamento Tipo A 
Na tabela 22, observa-se que a média do nível geral de comportamento tipo A é maior no grupo $\mathrm{R}(72,5)$ do que no grupo $\mathrm{RC}(69,4)$ e que na amostra total é de 70,95 , o que indica alto resultado no teste.

Tabela 22: Distribuição da variável "comportamento tipo A", considerando os grupos R e RC separadamente e a amostra total (médias e desvio padrão).

\begin{tabular}{l|ccc}
\hline $\begin{array}{l}\text { Nível geral de } \\
\text { comportamento } \\
\text { tipo A }\end{array}$ & Repórter & $\begin{array}{c}\text { Repórter } \\
\text { cinematográfico }\end{array}$ & $\begin{array}{c}\text { Amostra } \\
\text { total }\end{array}$ \\
\hline Média & & & \\
Desvio padrão & 11,84 & 69,4 & 70,95 \\
Nível geral & ALTO & 11,61 & 11,68 \\
\hline
\end{tabular}

Abaixo é demonstrado o resultado da análise estatística que compara os dois grupos.

Tabela 23: Análise de significância para a variável "comportamento tipo A", considerando a amostra total de R e RC.

\begin{tabular}{llll}
\hline G & Mann Whitney U & p & Conclusão \\
\hline R/RC & $\mathbf{1 7 4 , 5}$ & $\mathbf{0 , 4 9 5}$ & NS \\
\hline
\end{tabular}

Conforme a tabela 23, apesar de ambos os grupos apresentarem nível geral de padrão de comportamento tipo A situado na faixa "alto", essa diferença não é estatisticamente significante.

\subsection{Análise dos resultados dos fatores específicos do BEPATYA}

Serão demonstrados abaixo os resultados obtidos no teste BEPATYA para cada fator específico, bem como as médias e o nível de padrão de comportamento apresentados, comparados entre os grupos R e RC e na AT. Ao todo são sete fatores avaliados: senso de competência, nervosismo, nível de ambição, impaciência, urgência de tempo, incapacidade de desligar-se e autosobrecarga. Níveis altos de média nos fatores específicos indicam que os sujeitos têm maior presença daquele fator no comportamento tipo A. 
Fator 1 - Senso de competência

Tabela 24: Média e desvio padrão obtidos para o fator "senso de competência".

\begin{tabular}{lccc}
\hline \multicolumn{1}{c}{ Fator $\mathbf{1}$} & Repórter & $\begin{array}{c}\text { Repórter } \\
\text { cinematográfico }\end{array}$ & AT \\
\hline Média & 3,68 & 3,46 & 3,58 \\
Desvio padrão & 0,68 & 0,67 & - \\
$\mathbf{N}$ & $(20)$ & $(20)$ & $(40)$ \\
Senso de competência & ALTO & ALTO & ALTO \\
\hline
\end{tabular}

A tabela 24 demonstra as médias e DP obtidas no teste para os sujeitos do grupo R e RC, o que indica alta presença do fator específico "senso de competência" no comportamento tipo A.

A figura 16 que segue ilustra a distribuição das médias.

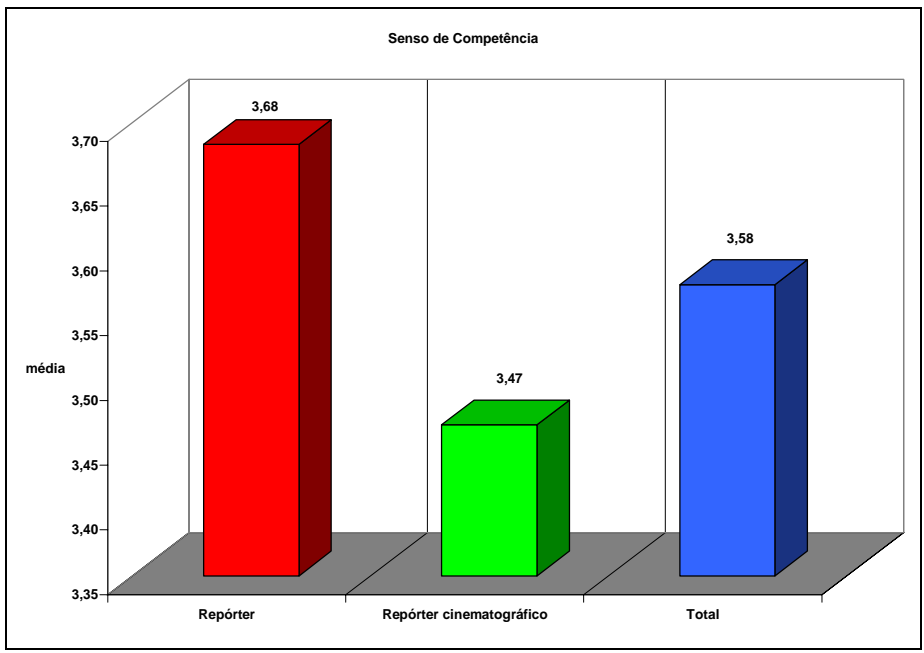

Figura 16. Distribuição do Padrão de Comportamento Tipo A - fator "senso de competência"

Abaixo é demonstrado o resultado da análise estatística que compara os dois grupos.

Tabela 25: Análise de significância para o fator "senso de competência" na amostra total.

\begin{tabular}{llll}
\hline G & $\mathbf{t}$ & $\mathbf{p}$ & Conclusão \\
\hline R/RC & $\mathbf{1 , 0 2}$ & $\mathbf{0 , 3 1 6}$ & NS \\
\hline
\end{tabular}

Conforme observado na tabela 25, os dois grupos apresentam o mesmo resultado quanto ao fator "senso de competência", não sendo o resultado estatisticamente significante. 


\section{Fator 2 - Nervosismo}

Tabela 26: Média e desvio padrão obtidos para o fator "nervosismo", considerando os grupos R e RC.

\begin{tabular}{lccc}
\hline \multicolumn{1}{c}{ Fator 2 } & Repórter & $\begin{array}{c}\text { Repórter } \\
\text { cinematográfico }\end{array}$ & AT \\
\hline Média & 3,43 & 3,10 & 3,27 \\
Desvio padrão & 1,25 & 0,21 & - \\
$\mathbf{N}$ & $(20)$ & $(20)$ & $(40)$ \\
Nervosismo & ALTO & ALTO & ALTO \\
\hline
\end{tabular}

Observa-se que as médias revelam alto nível do fator específico "nervosismo" no comportamento tipo A. A figura que segue, ilustra a distribuição das médias.

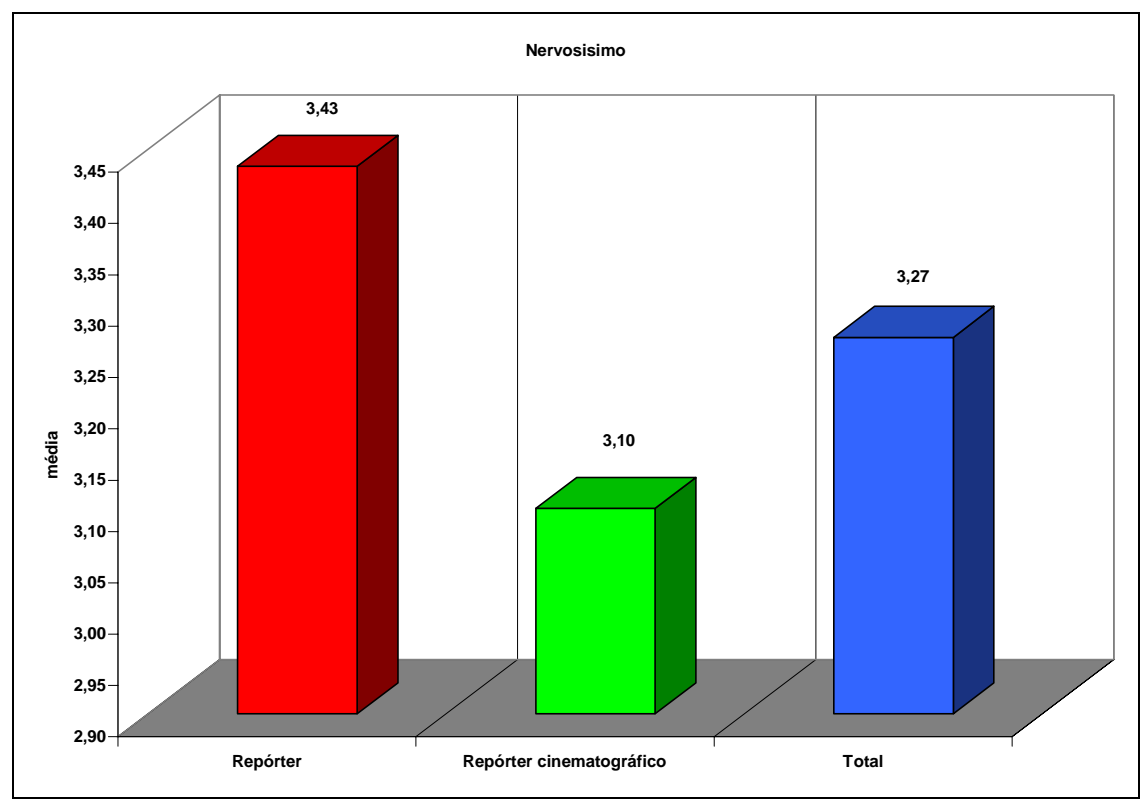

Figura 17. Distribuição do Padrão de Comportamento Tipo A - fator “nervosismo”.

Abaixo é demonstrado o resultado da análise estatística que compara os dois grupos.

Tabela 27: Análise de significância para o fator "nervosismo" na amostra total.

\begin{tabular}{llll}
\hline G & $\mathbf{t}$ & $\mathbf{p}$ & Conclusão \\
\hline R/RC & 1,257 & 0,216 & NS \\
\hline
\end{tabular}

Verifica-se na tabela 27 que a diferença entre os dois grupos quanto ao fator "nervosismo" não é estatisticamente significante. 


\section{Fator 3 - Nível de ambição}

Tabela 28: Média e desvio padrão obtidos para o fator "nível de ambição", considerando os grupos R e RC.

\begin{tabular}{lccc}
\hline \multicolumn{1}{c}{ Fator $\mathbf{3}$} & Repórter & $\begin{array}{c}\text { Repórter } \\
\text { cinematográfico }\end{array}$ & AT \\
\hline Média & 3,80 & 3,63 & 3,27 \\
Desvio padrão & 0,57 & 0,60 & - \\
$\mathbf{N}$ & $(20)$ & $(20)$ & $(40)$ \\
Nível de ambição & ALTíSSIMO & ALTO & ALTíSSIMO
\end{tabular}

A tabela 28 demonstra altíssimo e alto níveis de ambição nos grupos $\mathrm{R} \mathrm{e} \mathrm{RC,} \mathrm{respectivamente,}$ com média altíssima ao se considerar a AT. A figura abaixo representa esses dados.

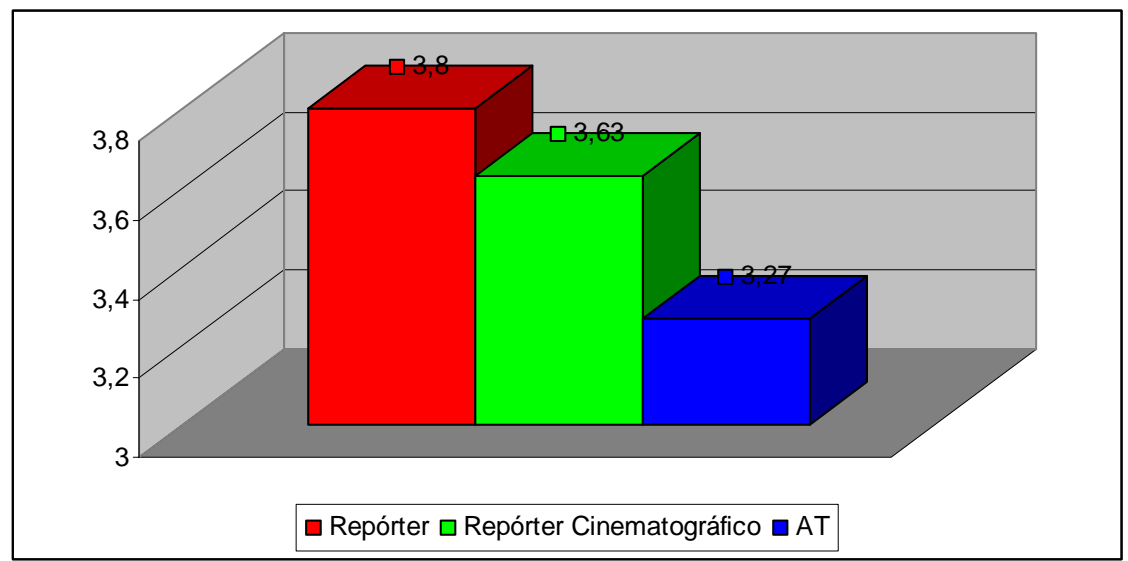

Figura 18. Distribuição do Padrão de Comportamento Tipo A - fator "nível de ambição".

Abaixo é demonstrado o resultado da análise estatística que compara os dois grupos.

Tabela 29: Análise de significância para o fator "nível de ambição" na amostra total.

\begin{tabular}{llll}
\hline G & t & p & Conclusão \\
\hline R/RC & $-\mathbf{0 , 8 9 5}$ & $\mathbf{0 , 3 7 6}$ & NS
\end{tabular}

A tabela 29 acima revela que a diferença demonstrada entre os grupos R e RC quanto ao fator "nível de ambição" não é estatisticamente significante. 
Fator 4 - Impaciência

Tabela 30: Média e desvio padrão obtidos para o fator "impaciência".

\begin{tabular}{lccc}
\hline \multicolumn{1}{c}{ Fator $\mathbf{4}$} & Repórter & $\begin{array}{c}\text { Repórter } \\
\text { cinematográfico }\end{array}$ & AT \\
\hline Média & 3,63 & 3,28 & 3,46 \\
Desvio padrão & 0,84 & 0,63 & - \\
$\mathbf{N}$ & $(20)$ & $(20)$ & $(40)$ \\
Nível de impaciência & ALTíSSIMO & ALTO & ALTO
\end{tabular}

A tabela 30 demonstra altíssimo e alto níveis de impaciência nos grupos $\mathrm{R}$ e RC, respectivamente, com média alta ao se considerar a AT. A figura abaixo representa esses dados.

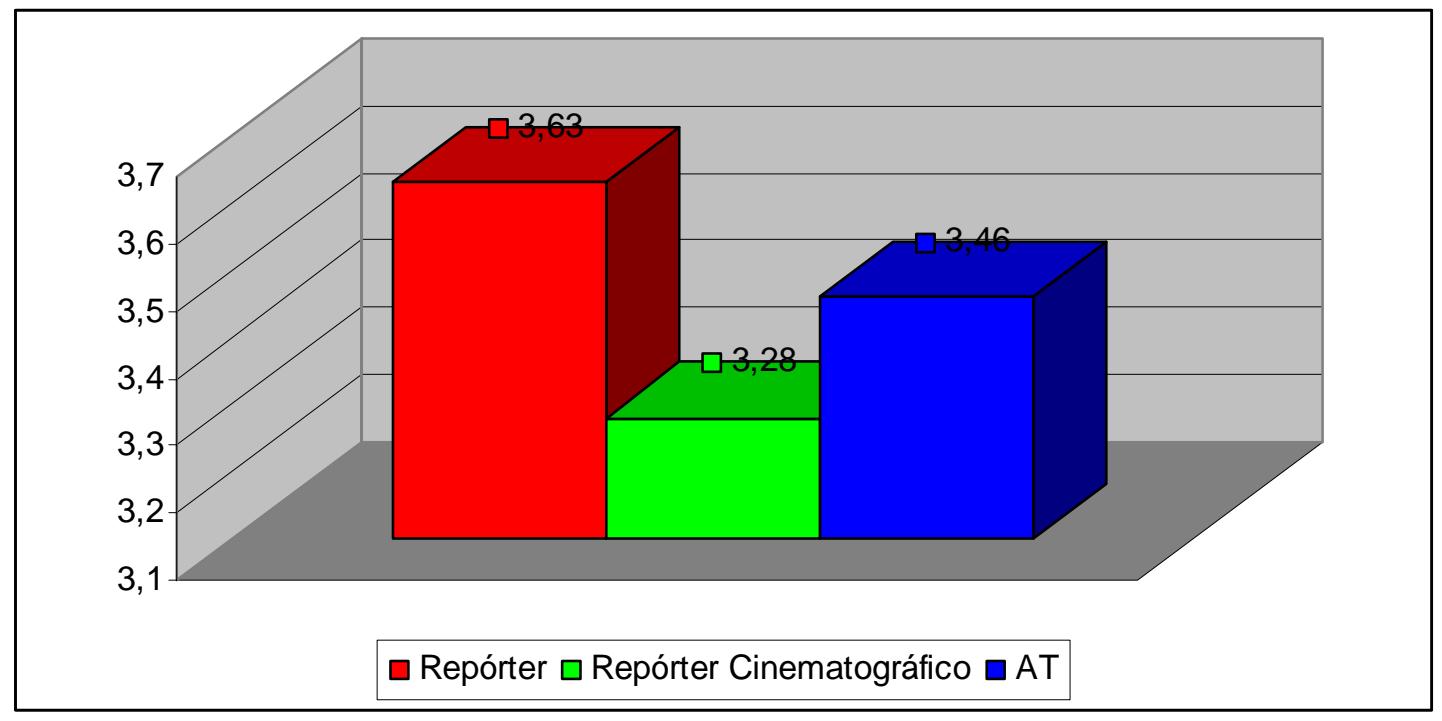

Figura 19. Distribuição do Padrão de Comportamento Tipo A - fator "impaciência”.

Abaixo é demonstrado o resultado da análise estatística que compara os dois grupos.

Tabela 31: Análise de significância para o fator "impaciência" na amostra total.

\begin{tabular}{llll}
\hline G & $\mathbf{t}$ & $\mathbf{p}$ & Conclusão \\
\hline R/RC & $-1,484$ & 0,146 & NS \\
\hline
\end{tabular}

Observa-se na tabela 31 que a diferença apresentada entre os grupos $\mathrm{R}$ e $\mathrm{RC}$ quanto ao fator "impaciência" não é estatisticamente significante. 
Fator 5 - Urgência de tempo

Tabela 32: Média e desvio padrão obtidos para o fator "urgência de tempo".

\begin{tabular}{lccc}
\hline \multicolumn{1}{c}{ Fator $\mathbf{5}$} & Repórter & $\begin{array}{c}\text { Repórter } \\
\text { cinematográfico }\end{array}$ & AT \\
\hline Média & 3,70 & 2,77 & 3,23 \\
Desvio padrão & 0,94 & 0,93 & - \\
$\mathbf{N}$ & $(20)$ & $(20)$ & $(40)$ \\
Urgência de tempo & MÉDIO & MÉDIO & MÉDIO \\
\hline
\end{tabular}

A figura abaixo representa a distribuição desses dados.

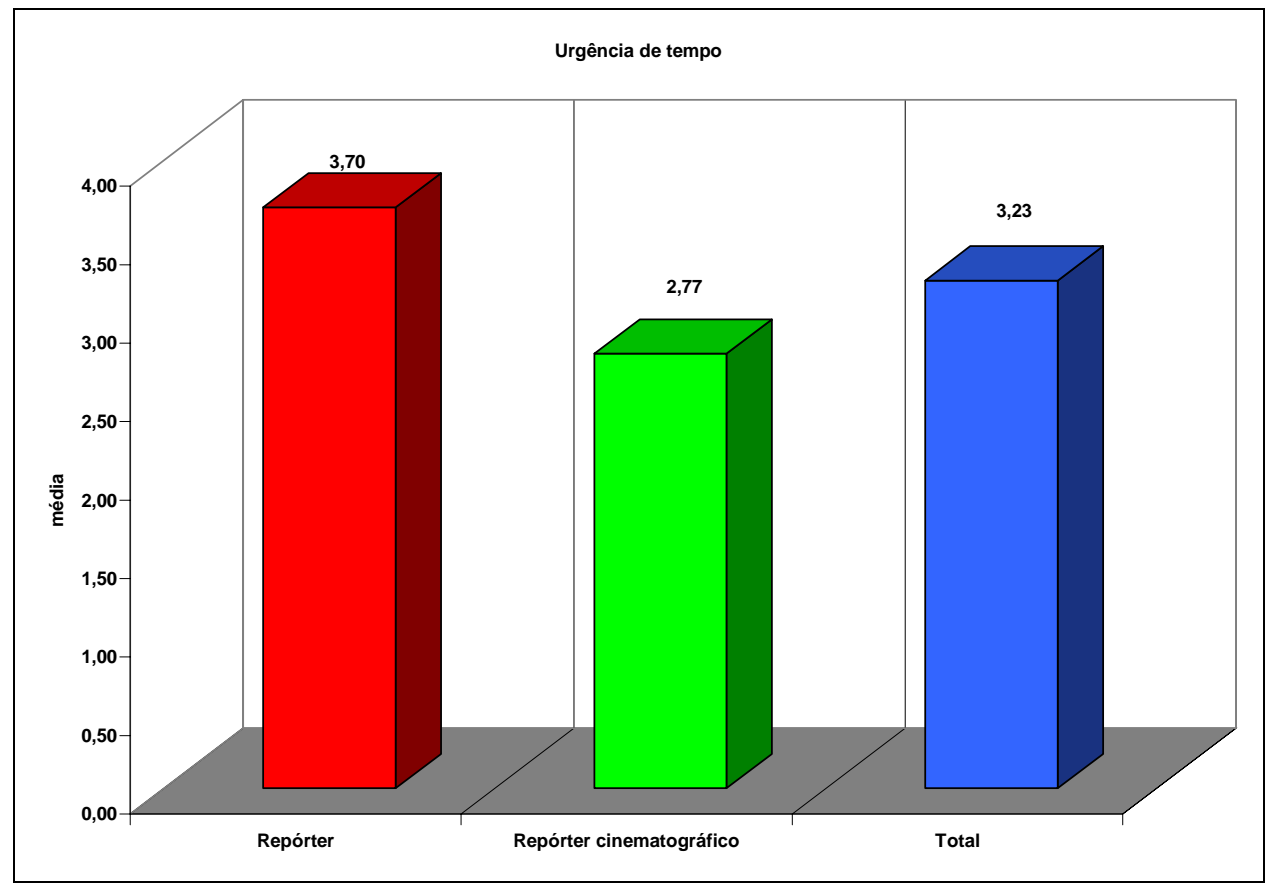

Figura 20. Distribuição do Padrão de Comportamento Tipo A - fator "urgência de tempo".

As médias apresentadas na figura 20 demonstram nível maior no grupo $\mathrm{R}$ do que no grupo $\mathrm{RC}$ quanto ao fator "urgência de tempo".

Os dados também são representados através do gráfico de error bar. 


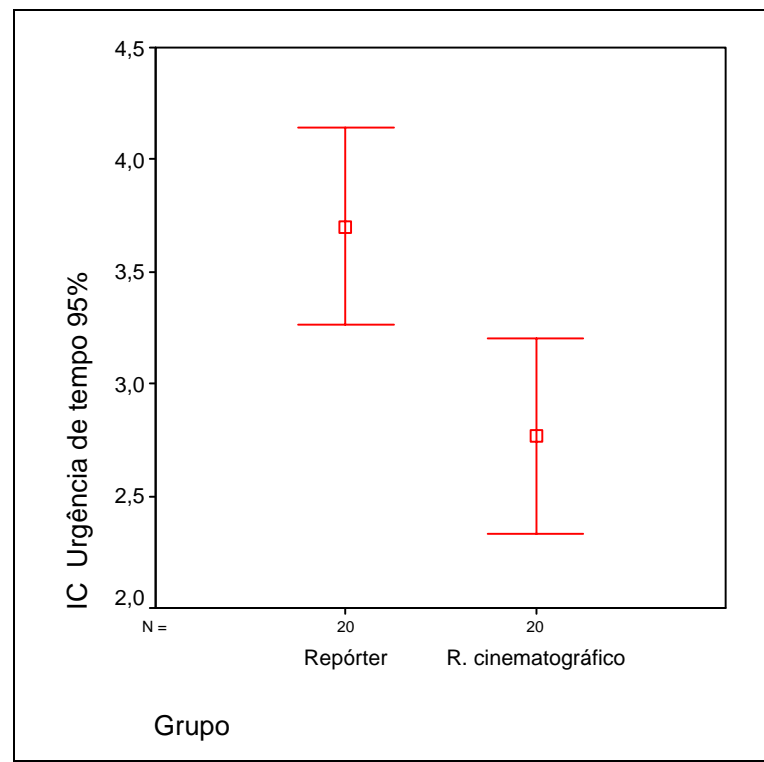

Figura 21: Médias para o fator "urgência de tempo".

Abaixo é demonstrado o resultado da análise estatística que compara os dois grupos.

Tabela 33: Análise de significância para o fator "urgência de tempo".

\begin{tabular}{llll}
\hline $\mathbf{G}$ & $\mathbf{t}$ & $\mathbf{p}$ & Conclusão \\
\hline R/RC & $\mathbf{3 , 1 5 1}$ & $\mathbf{0 , 0 0 3}$ & significante \\
\hline
\end{tabular}

A tabela 33 demonstra que há diferença estatisticamente significante quanto ao fator "urgência de tempo" entre os dois grupos. 
Fator 6 - Incapacidade de desligar-se

Tabela 34: Média e desvio padrão obtidos para o fator "incapacidade de desligar-se".

\begin{tabular}{lccc}
\hline \multicolumn{1}{c}{ Fator $\mathbf{6}$} & Repórter & $\begin{array}{c}\text { Repórter } \\
\text { cinematográfico }\end{array}$ & AT \\
\hline Média & 3,37 & 3,12 & 3,24 \\
Desvio padrão & 0,94 & 0,93 & - \\
$\mathbf{N}$ & $(20)$ & $(20)$ & $(40)$ \\
$\begin{array}{l}\text { Incapacidade de } \\
\text { desligar-se }\end{array}$ & MÉDIO & MÉDIO & MÉDIO \\
\hline
\end{tabular}

A figura abaixo representa a distribuição desses dados.

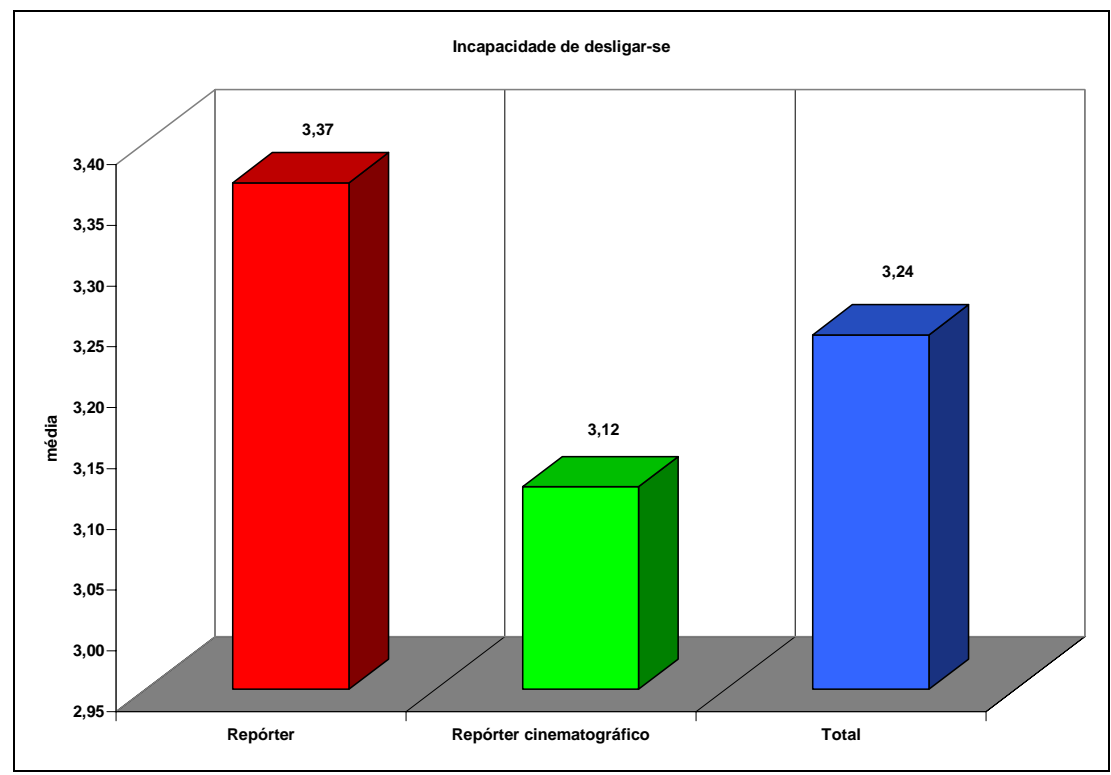

Figura 22. Distribuição do Padrão de Comportamento Tipo A - fator "incapacidade de desligar-se".

As médias apresentadas na figura 22 demonstram nível maior no grupo $\mathrm{R}$ do que no grupo $\mathrm{RC}$ quanto ao fator "incapacidade de desligar-se". Abaixo é demonstrado o resultado da análise estatística que compara os dois grupos.

Tabela 35: Análise de significância para o fator "incapacidade de desligar-se" na amostra total.

\begin{tabular}{lllc}
\hline G & $\mathbf{t}$ & $\mathbf{p}$ & Conclusão \\
\hline R/RC & $\mathbf{0 , 9 9 4}$ & $\mathbf{0 , 3 2 7}$ & NS
\end{tabular}

Observa-se na tabela 35 que a diferença entre os dois grupos quanto ao fator "incapacidade de desligar-se" não é estatisticamente significante. 
Fator 7 - Auto-sobrecarga

Tabela 36: Média e desvio padrão obtidos para o fator "auto-sobrecarga".

\begin{tabular}{lccc}
\hline \multicolumn{1}{c}{ Fator $\mathbf{7}$} & Repórter & $\begin{array}{c}\text { Repórter } \\
\text { cinematográfico }\end{array}$ & AT \\
\hline Média & 3,25 & 3,23 & 3,24 \\
Desvio padrão & 0,87 & 0,59 & - \\
N & $(20)$ & $(20)$ & $(40)$ \\
Auto-sobrecarga & ALTO & MÉDIO & MÉDIO \\
\hline
\end{tabular}

A figura abaixo representa a distribuição desses dados.

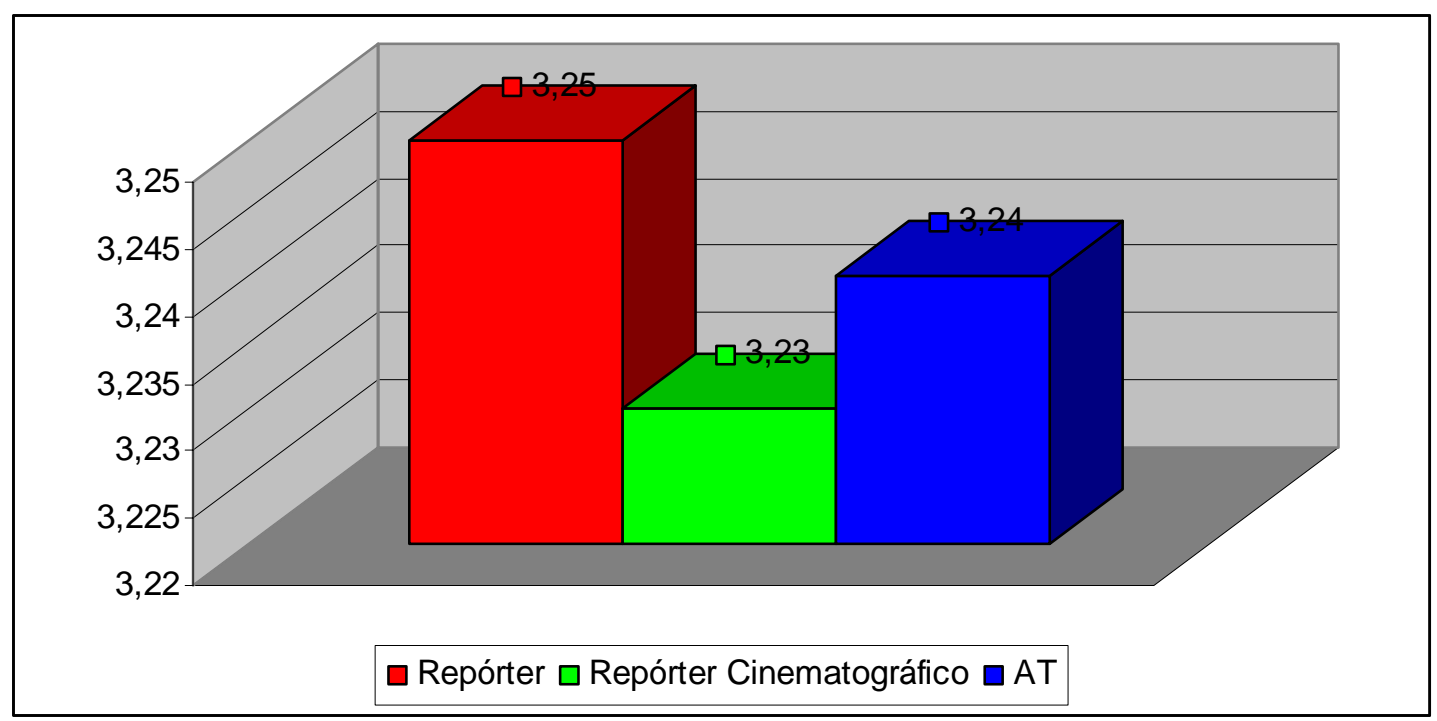

Figura 23. Distribuição do Padrão de Comportamento Tipo A - fator "auto-sobrecarga".

Conforme observado na figura 23, o fator "auto-sobrecarga" apresenta valor "alto" no grupo R, "médio" no grupo RC e "médio" na AT. Abaixo é demonstrado o resultado da análise estatística que compara os dois grupos.

Tabela 37: Análise de significância para o fator "auto-sobrecarga" na amostra total.

\begin{tabular}{lccc}
\hline $\mathbf{G}$ & $\mathbf{t}$ & $\mathbf{p}$ & Conclusão \\
\hline $\mathbf{R} / \mathbf{R C}$ & $\mathbf{- 0 , 0 7 1}$ & $\mathbf{0 , 9 4 4}$ & $\mathbf{N S}$ \\
\hline $\begin{array}{l}\text { Verifica-se que a diferença entre os dois } \\
\text { estatisticamente significante. }\end{array}$
\end{tabular}




\section{LISTA DE SINTOMAS DE STRESS - LSS/VAS}

\subsection{PRESENÇA DE STRESS}

São apresentadas a seguir, nas tabelas 38 e 39, as distribuições dos resultados em \%, as médias, os desvios padrão e os níveis obtidos para a variável "presença de sintomas de stress" nos grupos R e RC e na AT.

Tabela 38: Distribuição dos resultados em \% da variável "presença de sintomas de stress", considerando os grupos $\mathrm{R}$ e RC separadamente e a amostra total.

\begin{tabular}{lccc}
\hline Presença dos sintomas & repórter & $\begin{array}{c}\text { Repórter } \\
\text { cinematográfico } \\
\%\end{array}$ & $\begin{array}{c}\text { Amostra total } \\
\%\end{array}$ \\
\hline Médio & $\%$ & 30,0 & 22,5 \\
Alto & 15,0 & 40,0 & 37,5 \\
Altíssimo & 35,0 & 30,0 & 40,0 \\
Total & 50,0 & 100,0 & 100,0 \\
N & 100,0 & $(20)$ & $(40)$ \\
\hline
\end{tabular}

A figura abaixo ilustra essa distribuição.

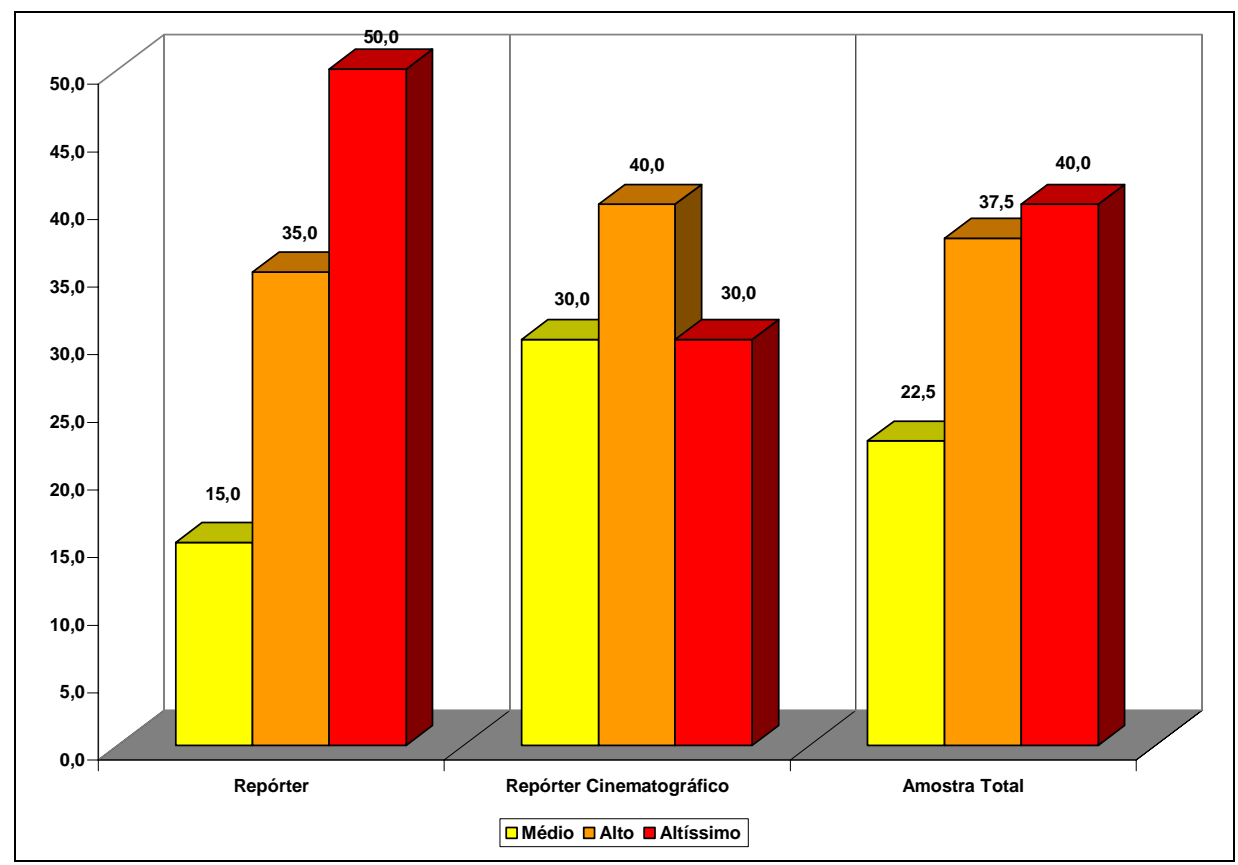

Figura 24. Distribuição da Presença de Sintomas de Stress. 
Tabela 39: Distribuição das médias, desvio padrão e nível da variável "presença de sintomas de stress", considerando os grupos R e RC separadamente e a amostra total.

\begin{tabular}{lccc}
\hline Presença dos sintomas & Repórter & $\begin{array}{c}\text { Repórter } \\
\text { cinematográfico }\end{array}$ & Amostra total \\
\hline Média & 64,0 & 59,7 & 61,8 \\
Desvio padrão & 18,41 & 19,19 & 18,69 \\
N & $(20)$ & $(20)$ & $(40)$ \\
Nível & ALTO (4) & ALTO (4) & ALTO(4) \\
\hline
\end{tabular}

A tabela 39 revela que o grupo R assinalou $64 \%$ dos 59 sintomas do teste LSS/VAS e que o grupo RC assinalou 59,7 \%. Ambos apresentaram, portanto, médias elevadas e nível alto (4) de presença de sintomas de stress, inclusive refletida na média da AT (61,8\%).

Abaixo a análise estatística dessa variável, comparando-se os dois grupos.

Tabela 40: Análise de significância para a variável "presença de sintomas de stress", considerando a amostra total de R e RC.

\begin{tabular}{llll}
\hline G & Mann Whitney U & p & Conclusão \\
\hline R/RC & 151,0 & 0,192 & NS \\
\hline
\end{tabular}

Constata-se na tabela 40 que, embora os grupos $\mathrm{R}$ e $\mathrm{RC}$ tenham apresentado nível alto de presença de sintomas de stress, essa diferença entre eles não é significante para a variável qualitativa (médio, alto, altíssimo). 


\subsection{FREQÜÊNCIA DE SINTOMAS DE STRESS}

Na sequiência são apresentados, nas tabelas 41 e 42, a distribuição dos resultados em \%, as médias, os desvios padrão e os níveis obtidos para a variável "freqüência de sintomas de stress" nos grupos R e RC separadamente e na AT.

Tabela 41: Distribuição dos resultados em \% da variável "freqüência de sintomas de stress", considerando os grupos $\mathrm{R}$ e RC separadamente e a amostra total.

\begin{tabular}{lccc}
\hline $\begin{array}{l}\text { Nível de } \\
\text { freqüência dos } \\
\text { sintomas }\end{array}$ & Repórter & $\begin{array}{c}\text { Repórter } \\
\text { cinematográfico } \\
\%\end{array}$ & $\begin{array}{c}\text { Amostra total } \\
\%\end{array}$ \\
\hline Baixo & $\%$ & 25,0 & 15,0 \\
Médio & 5,0 & 60,0 & 70,0 \\
Médio alto & 80,0 & 10,0 & 12,5 \\
Alto & 15,0 & 5,0 & 2,5 \\
Total & 0,0 & 100,0 & 100,0 \\
N & 100,0 & $(20)$ & $(40)$ \\
\hline
\end{tabular}

Como se pode observar, a figura 25 demonstra essa distribuição.

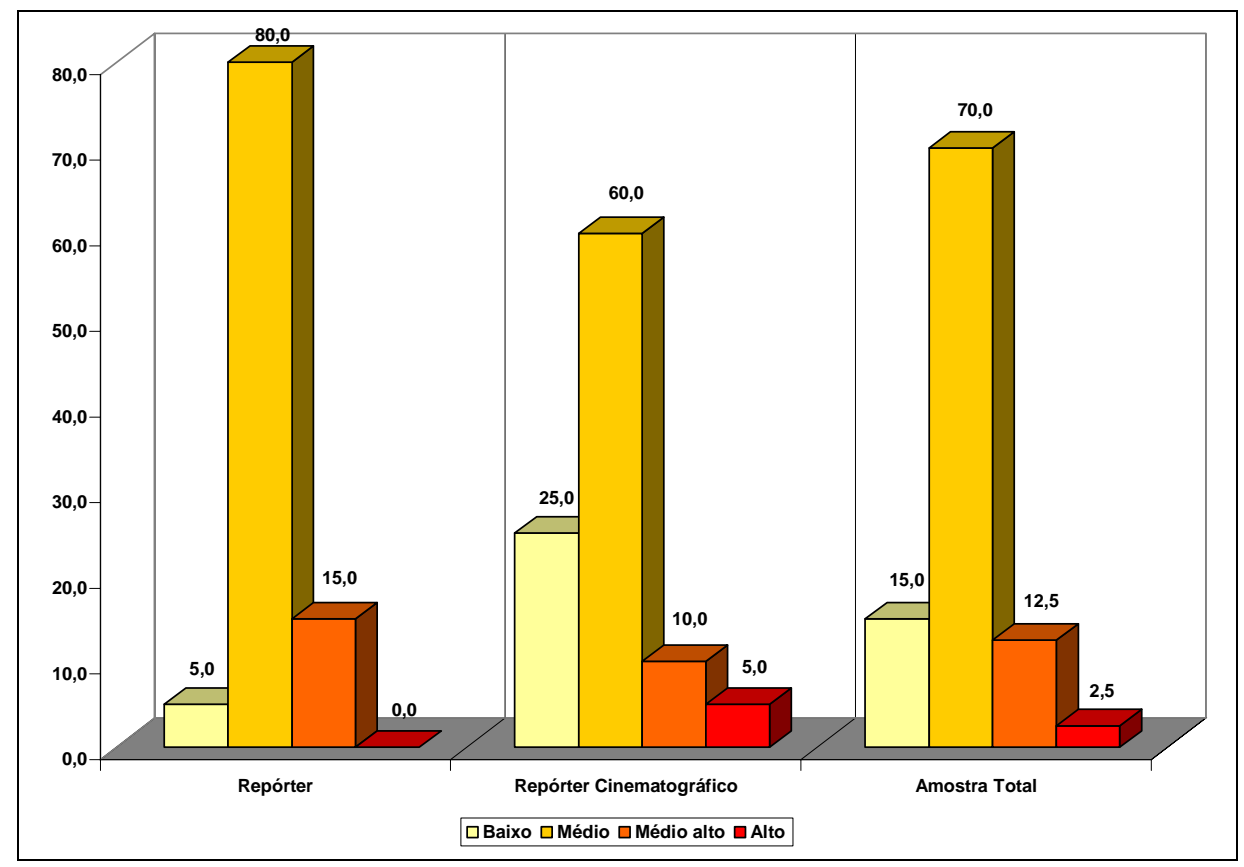

Figura 25. Médias da presença de sintomas de stress. 
Tabela 42: Distribuição das médias, desvio padrão e nível da variável "freqüência de sintoma de stress", considerando os grupos R e RC separadamente e a amostra total.

\begin{tabular}{lccc}
\hline $\begin{array}{c}\text { Média de } \\
\text { freqüência }\end{array}$ & Repórter & $\begin{array}{c}\text { Repórter } \\
\text { cinematográfico }\end{array}$ & $\begin{array}{c}\text { Amostra } \\
\text { total }\end{array}$ \\
\hline Média & 1,33 & 1,25 & 1,29 \\
Desvio padrão & 0,17 & 0,26 & 0,22 \\
N & $(20)$ & $(20)$ & $(40)$ \\
Nível & MÉDIO (2) & MÉDIO (2) & MÉDIO (2) \\
\hline
\end{tabular}

Na tabela 42, verificam-se as médias dos grupos R e RC separadamente e da AT, indicadoras de que ambos apresentaram nível médio (2) de freqüência de stress.

Abaixo a análise estatística da variável "freqüência de sintomas de stress", comparando-se os dois grupos.

Tabela 43: Análise de significância para a variável "freqüência de sintomas de stress", considerando a amostra total de R e RC.

\begin{tabular}{llll}
\hline G & Mann Whitney $U$ & p & Conclusão \\
\hline R/RC & 167,5 & 0,383 & NS \\
\hline
\end{tabular}

Observa-se que a diferença entre os grupos R e RC quanto ao nível de freqüência de sintomas de stress não é estatisticamente significante. 


\subsection{INTENSIDADE DE SINTOMAS DE STRESS}

Abaixo são demonstrados, nas tabelas 44 e 45, as distribuições dos resultados em \%, as médias, os desvios padrão e os níveis obtidos para a variável "intensidade de sintomas de stress" nos grupos R e RC separadamente e na AT.

Tabela 44: Distribuição dos resultados em \% da variável "intensidade de sintomas de stress", considerando os grupos R e RC separadamente e a amostra total.

\begin{tabular}{lccc}
\hline $\begin{array}{c}\text { Intensidade da } \\
\text { freqüência de } \\
\text { stress }\end{array}$ & Repórter & $\begin{array}{c}\text { Repórter } \\
\text { cinematográfico } \\
\%\end{array}$ & $\begin{array}{c}\text { Amostra } \\
\text { total } \\
\%\end{array}$ \\
Baixo & $\%$ & 15,0 & 7,5 \\
Médio & 0,0 & 70,0 & 55,0 \\
Médio alto & 40,0 & 10,0 & 30,0 \\
Alto & 50,0 & 5,0 & 7,5 \\
Total & 10,0 & 100,0 & 100,0 \\
N & 100,0 & $(20)$ & $(40)$ \\
Nível & $(20)$ & MÉDIO & MÉDIO \\
\hline
\end{tabular}

A figura abaixo representa graficamente essa distribuição.

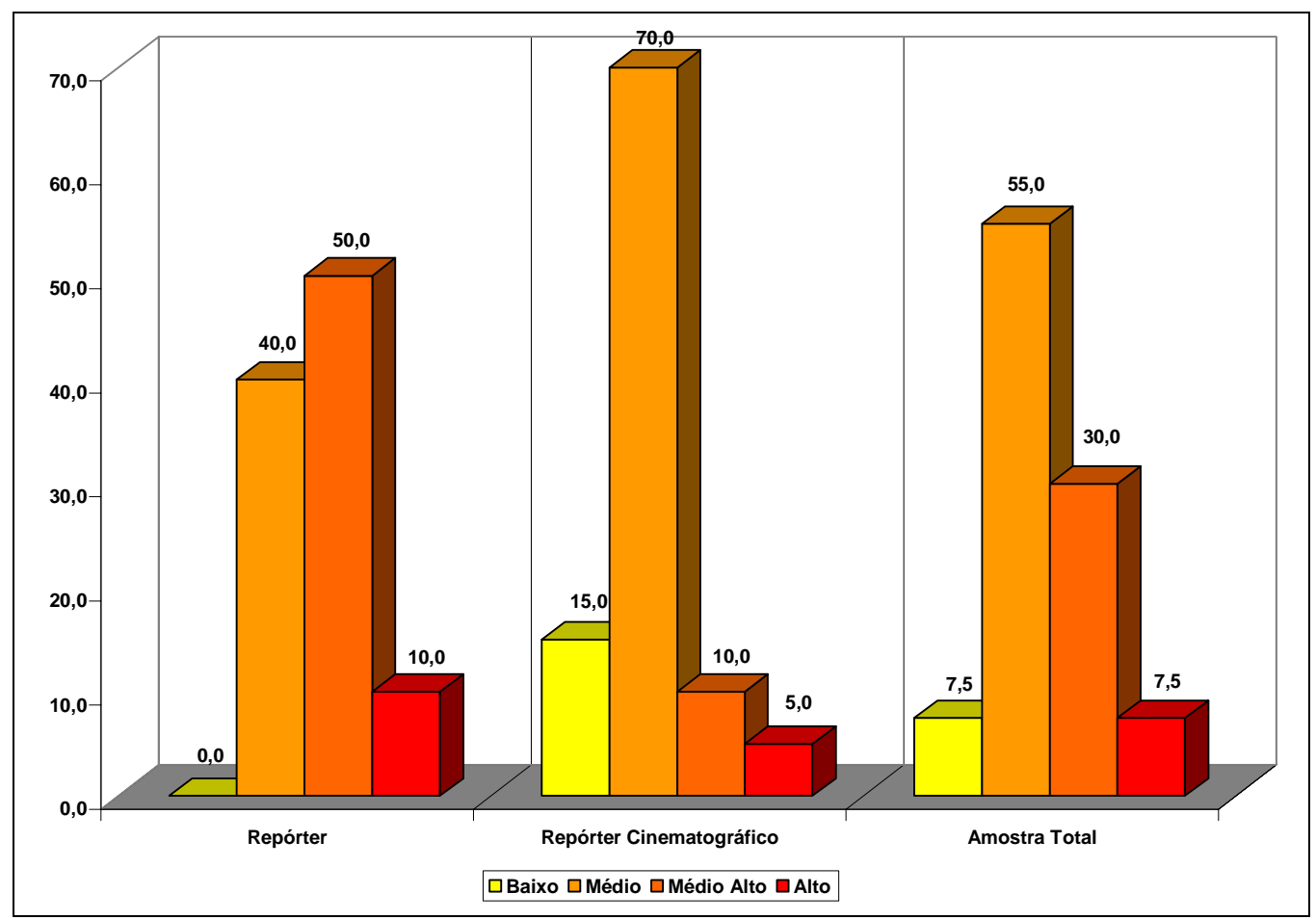

Figura 26. Médias de intensidade de sintomas de stress. 
Tabela 45: Distribuição das médias, desvio padrão e nível da variável "intensidade de sintomas de stress", considerando os grupos R e RC separadamente e a amostra total.

\begin{tabular}{lccc}
\hline $\begin{array}{c}\text { Intensidade da } \\
\text { freqüência de } \\
\text { stress }\end{array}$ & Repórter & $\begin{array}{c}\text { Repórter } \\
\text { cinematográfico }\end{array}$ & $\begin{array}{c}\text { Amostra } \\
\text { total }\end{array}$ \\
\hline Média & 3,78 & 2,63 & 3,20 \\
Desvio padrão & 1,33 & 1,37 & 1,46 \\
$\mathbf{N}$ & $(20)$ & $(20)$ & $(40)$ \\
Nível & MÉDIO & MÉDIO & MÉDIO \\
& ALTO (3) & (2) & (2) \\
\hline
\end{tabular}

A tabela 45 acima demonstra que o grupo $\mathrm{R}$ apresentou média mais elevada do que o grupo RC quanto à intensidade de sintomas de stress, revelando nível médio alto (3) enquanto o grupo RC mostrou nível médio (2).

Como se pode observar, a figura 27 demonstra outra forma de representação da distribuição das médias, através do gráfico de error bar.

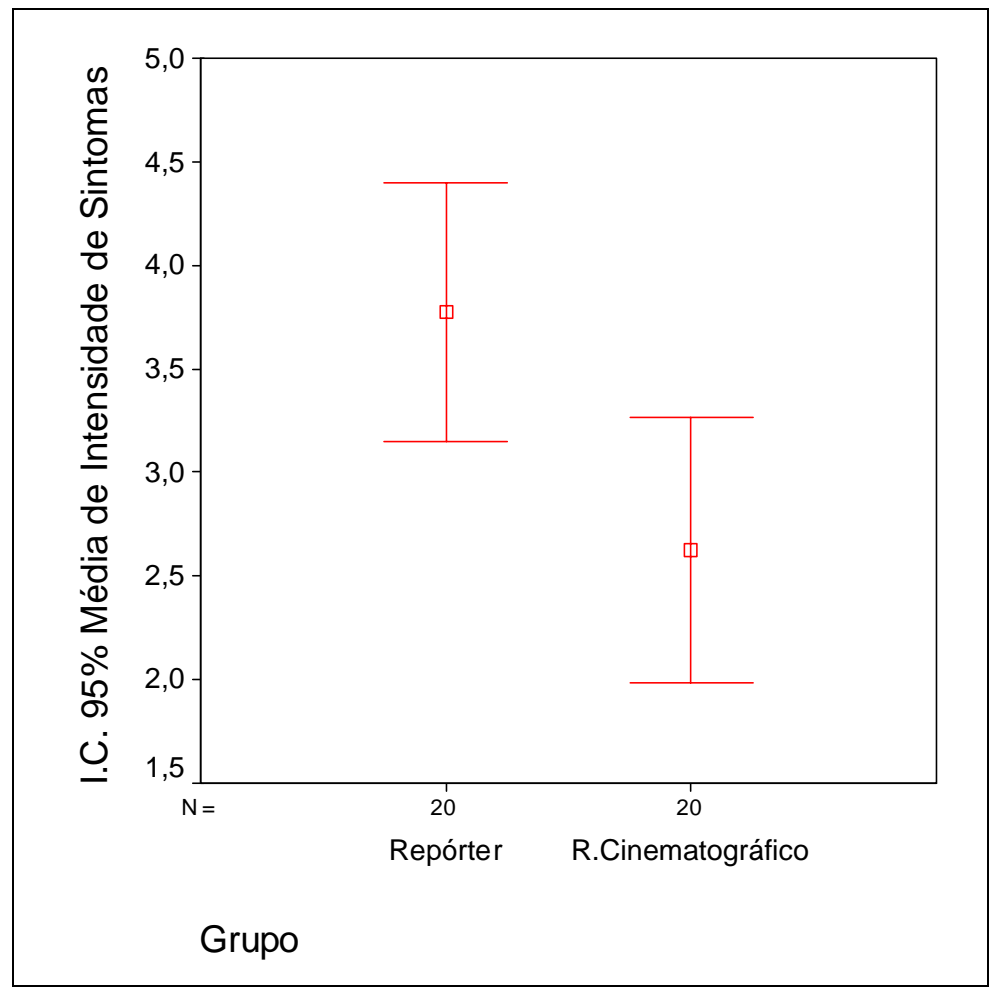

Figura 27. Médias da intensidade de sintomas de stress.

Como graficamente as barras não estão interseccionadas, observa-se que a diferença é estatisticamente significante. 
Abaixo a comparação estatística entre os dois grupos quanto à variável "intensidade de sintomas de stress".

Tabela 46: Análise de significância para a variável "intensidade de sintomas de stress", considerando a amostra total de R e RC.

\begin{tabular}{llll}
\hline G & Mann Whitney $U$ & p & Conclusão \\
\hline R/RC & 101,0 & $\mathbf{0 , 0 0 7}$ & significante \\
\hline
\end{tabular}

Conforme a tabela 46, a diferença apresentada quanto à intensidade de sintomas de stress, do grupo R em relação ao grupo RC é estatisticamente significante. 


\subsection{NÍVEL GERAL DE STRESS}

A tabela 47 abaixo demonstra o nível geral de stress obtido na amostra pesquisada, após a análise das seguintes variáveis: presença, freqüência e intensidade de sintomas de stress.

Tabela 47: Distribuição do nível geral de stress nos grupos R e RC separadamente e na amostra total.

\begin{tabular}{lccc}
\hline $\begin{array}{c}\text { Nível geral de } \\
\text { stress }\end{array}$ & $\begin{array}{c}\text { Repórter } \\
\%\end{array}$ & $\begin{array}{c}\text { Repórter } \\
\text { cinematográfico } \\
\%\end{array}$ & $\begin{array}{c}\text { Amostra total } \\
\%\end{array}$ \\
\hline Médio & 25,0 & 40,0 & 32,5 \\
Médio alto & 45,0 & 50,0 & 45,0 \\
Alto & 30,0 & 10,0 & 22,5 \\
Total & 100,0 & 100,0 & 100,0 \\
N & 20 & 20 & 40 \\
Nível & MÉDIO ALTO & MÉDIO ALTO & MÉDIO ALTO \\
& $(3)$ & $(3)$ & \\
\hline
\end{tabular}

Observa-se que os grupos R e RC apresentam o mesmo resultado quanto ao nível geral de stress, mantendo-se na categoria médio alto (3).

A figura 28 demonstra graficamente a distribuição dos resultados em \% nos grupos R e RC e na AT.

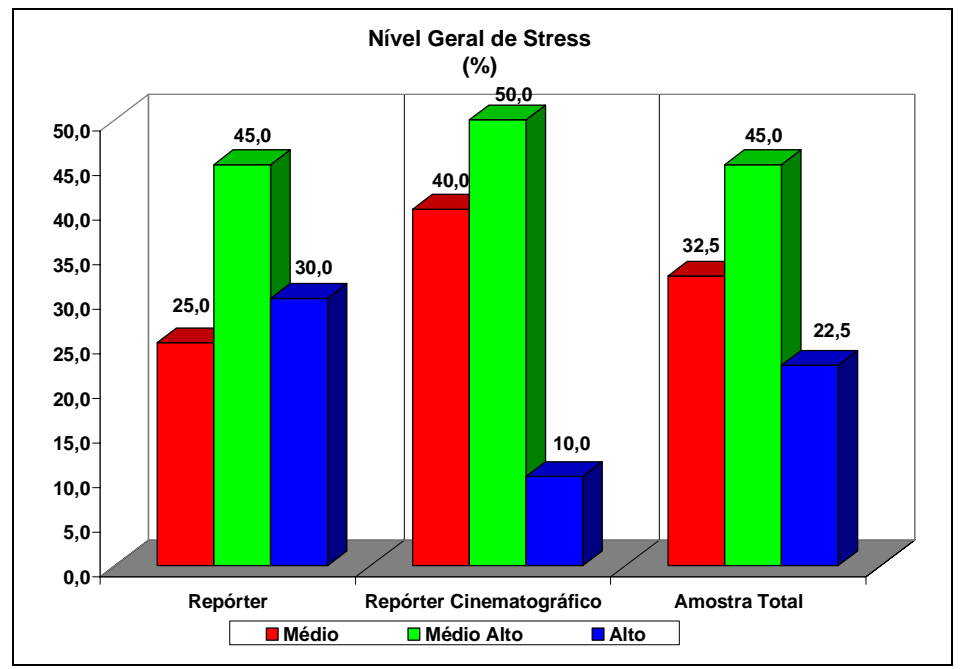

Figura 28. Distribuição dos resultados do nível geral de stress. 
Abaixo a comparação estatística entre os dois grupos quanto ao nível geral de stress.

Tabela 48: Análise de significância para o nível geral de stress, considerando a amostra total de R e RC.

\begin{tabular}{llll}
\hline G & Mann Whitney $U$ & p & Conclusão \\
\hline R/RC & 149,0 & 0,174 & NS \\
\hline
\end{tabular}

Os resultados da tabela 48 indicam que não há diferença estatisticamente significante entre os grupos R e RC quanto ao nível geral de stress.

\section{Classificação dos Sintomas}

Para fins ilustrativos, na tabela 49 estão relacionados as médias e o ranking dos 12 itens de respostas mais representativas da lista de sintomas para a amostra de repórteres.

Tabela 49: Ranking dos itens de sintomas mais representativos no grupo R.

\begin{tabular}{|l|l|l|l|}
\hline Ranking & Média & Item & Conteúdo \\
\hline $1^{\mathbf{o}}$ & 138,4 & 05 & No fim de um dia de trabalho, estou desgastado(a) \\
\hline $2^{\mathbf{o}}$ & 132,0 & 21 & Tenho cansaço \\
\hline $3^{\mathbf{o}}$ & 128,6 & 33 & Sinto sobrecarga de trabalho \\
\hline $4^{\mathbf{o}}$ & 123,1 & 55 & Meus músculos estão sempre tensos \\
\hline $5^{\mathbf{o}}$ & 109,1 & 35 & Esqueço-me das coisas \\
\hline $6^{\mathbf{o}}$ & 106,1 & 13 & Quando me levanto de manhã, já estou cansado(a) \\
\hline $7^{\mathbf{o}}$ & 104,9 & 16 & Fico esgotado(a) emocionalmente \\
\hline $8^{\mathbf{o}}$ & 104,3 & 38 & Sinto exaustão física \\
\hline $9^{\mathbf{o}}$ & 101,2 & 09 & Tenho pensamentos que me deixam ansioso(a) \\
\hline $10^{\mathbf{o}}$ & 97,5 & 17 & Sinto angústia \\
\hline $11^{\mathbf{o}}$ & 95,7 & 20 & Apresento distúrbios gastrointestinais (acidez estomacal, colite, úlceras etc.) \\
\hline $12^{\mathbf{o}}$ & 95,2 & 12 & Aperto as mandíbulas \\
\hline
\end{tabular}


A seguir, na tabela 50, também estão relacionados as médias e o ranking dos 12 itens de respostas mais representativas da lista de sintomas para a amostra de repórteres cinematográficos.

Tabela 50: Ranking dos itens de sintomas mais representativos no grupo RC.

\begin{tabular}{|l|l|l|l|}
\hline Ranking & Média & Item & Conteúdo \\
\hline $1^{\mathbf{o}}$ & 108,0 & 09 & Tenho pensamentos que me deixam ansioso(a) \\
\hline $2^{\mathbf{o}}$ & 93,8 & 23 & Sinto dores nas costas \\
\hline $3 .^{\mathbf{o}}$ & 91,9 & 05 & No fim de um dia de trabalho, estou desgastado(a) \\
\hline $4^{\mathbf{o}}$ & 84,5 & 33 & Sinto sobrecarga de trabalho \\
\hline $5^{\mathbf{o}}$ & 79,5 & 55 & Meus músculos estão sempre tensos \\
\hline $6^{\mathbf{o}}$ & 79,0 & 16 & Fico esgotado(a) emocionalmente \\
\hline $7^{\mathbf{o}}$ & 76,5 & 07 & Como demais \\
\hline $8^{\mathbf{o}}$ & 73,3 & 35 & Esqueço-me das coisas \\
\hline $9^{\mathbf{o}}$ & 72,6 & 24 & Tenho insônia \\
\hline $10^{\mathbf{o}}$ & 72,6 & 59 & Tenho vontade de ficar sozinho(a) \\
\hline $11^{\mathbf{o}}$ & 72,1 & 21 & Tenho cansaço \\
\hline $12^{\mathbf{o}}$ & 71,9 & 17 & Sinto angústia \\
\hline
\end{tabular}

A comparação da distribuição dos sintomas na amostra de repórteres e repórteres cinematográficos se apresenta conforme a tabela 51.

Tabela 51. Distribuição dos sintomas de stress no grupo R e RC (\%)

\begin{tabular}{l|c|c|}
\hline \multirow{2}{*}{$\begin{array}{l}\text { EMOCIONAIS } \\
\text { COGNITIVOS }\end{array}$} & $\begin{array}{c}\text { Repórter } \\
\%\end{array}$ & $\begin{array}{c}\text { Repórter } \\
\text { cinematográfico } \\
\%\end{array}$ \\
\cline { 2 - 3 } $\begin{array}{l}\text { SOCIAIS } \\
\text { FISIOLÓGICOS }\end{array}$ & 30,4 & 29,8 \\
\cline { 2 - 3 } Total & 28,5 & 27,5 \\
\cline { 2 - 3 } & 18,1 & 23,8 \\
\cline { 2 - 3 } & 100,0 & 19,0 \\
\hline
\end{tabular}

Os dois grupos (R e RC) apresentam categorias de sintomas com a mesma ordem de dominância: emocionais, cognitivos, sociais e fisiológicos, como demonstrado nas tabelas 51 acima. 
Comparando-se as respostas das tabelas 49 e 50 dos grupos R e RC, verificam-se na tabela 52 sete respostas comuns entre os doze itens mais representativos de sintomas de stress listados pelos dois grupos.

Tabela 52 Relação das respostas de sintomas de stress que apareceram nos dois grupos.

\section{Conteúdo}

No fim de um dia de trabalho, estou desgastado(a)

Tenho cansaço

Sinto sobrecarga de trabalho

Meus músculos estão sempre tensos

Esqueço-me das coisas

Tenho pensamentos que me deixam ansioso(a)

Sinto angústia 


\subsection{FASES DE STRESS}

Na tabela 53 se observam os resultados quanto às fases de stress para a amostra pesquisada.

Tabela 53: Distribuição das fases de stress nos grupos R e RC separadamente e na amostra total.

\begin{tabular}{lccc}
\hline \multicolumn{1}{c}{ Fases de stress } & Repórter & $\begin{array}{c}\text { Repórter } \\
\text { cinematográfico } \\
\%\end{array}$ & $\begin{array}{c}\text { Amostra total } \\
\end{array}$ \\
$\%$ & 25,0 & 40,0 & $\%$ \\
\hline Alarme & 40,0 & 50,0 & 32,5 \\
Perigo & 35,0 & 10,0 & 45,0 \\
Perigo agudo & 100,0 & 100,0 & 22,5 \\
Total & 20 & 20 & 100,0 \\
N & PERIGO AGUDO & PERIGO AGUDO & PERIGO AGUDO \\
Fases de stress & (4) & (4) & (4) \\
\hline
\end{tabular}

Observa-se que os grupos R e RC apresentam o mesmo resultado, situando-se na fase de perigo agudo se stress (nível 4).

Abaixo segue a representação gráfica das fases de stress nos grupos R e RC e na AT.

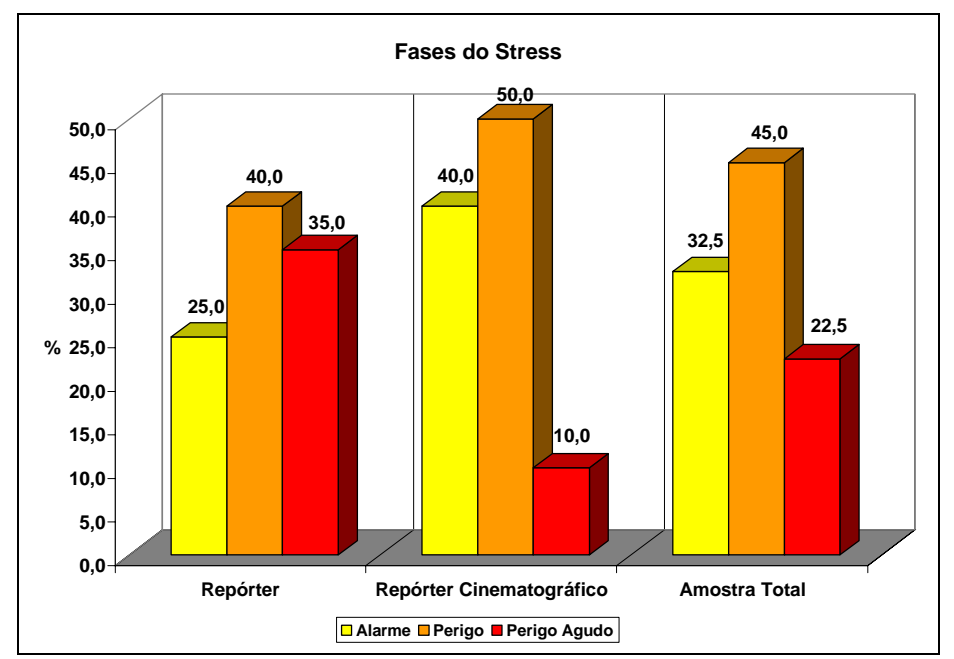

Figura 29. Distribuição das fases de stress nos grupos R e RC e na AT, em \%. 
Abaixo a comparação estatística entre os dois grupos quanto às fases de stress.

Tabela 54: Análise de significância para as fases de stress, considerando a amostra total de R e RC.

\begin{tabular}{llll}
\hline G & Mann Whitney $U$ & p & Conclusão \\
\hline R/RC & 143,0 & 0,127 & NS \\
\hline
\end{tabular}

Os grupos não demonstram diferenças significantes entre si, todavia ressalta-se que ambos estão na fase de stress de perigo agudo, que se localiza imediatamente antes da fase de exaustão. 


\section{COMPETÊNCIA}

Para a aferição do nível de competência na amostra pesquisada, foram considerados os seguintes tipos de resultado: NA - não atende (o sujeito não atende ao esperado para o cargo), ED - em desenvolvimento (o sujeito está em processo de desenvolvimento no cargo), A - atende (o sujeito atende plenamente ao esperado para o cargo) e S - supera (o sujeito supera o esperado para o cargo). O resultado foi obtido por meio da avaliação final consensual entre avaliadores e sujeitos avaliados.

A tabela 55 demonstra a escala de pontuação utilizada para a classificação do nível de competência.

Tabela 55. Escala de Pontuação

\begin{tabular}{lcc}
\hline Pontuação & $\begin{array}{c}\text { Nível de } \\
\text { competência }\end{array}$ & Operacionalização \\
\hline $0-0,5$ & NA & Não Atende \\
$0,6-1,5$ & ED & $\begin{array}{c}\text { Em } \\
\text { desenvolvimento } \\
\text { Atende }\end{array}$ \\
$1,6-2,5$ & A & Supera \\
$>2,6$ & S & Sul \\
\hline
\end{tabular}

A tabela 56 abaixo identifica a distribuição dos resultados do nível de competência.

Tabela 56: Distribuição do nível de competência (\%) nos grupos R e RC separadamente e na amostra total.

\begin{tabular}{lccc}
\hline Competência & $\begin{array}{c}\text { Repórter } \\
\%\end{array}$ & $\begin{array}{c}\text { Repórter } \\
\text { cinematográfico } \\
\%\end{array}$ & $\begin{array}{c}\text { Amostra } \\
\text { total } \\
\%\end{array}$ \\
\hline Não atende (0) & 0,0 & 0,0 & 0,0 \\
Em desenvolvimento (1) & 15,0 & 30,0 & 22,5 \\
Atende (2) & 80,0 & 70,0 & 75,0 \\
Supera (3) & 5,0 & 0,0 & 2,5 \\
Total & 100,0 & 100,0 & 100,0 \\
N & $(20)$ & $(20)$ & $(40)$ \\
\hline
\end{tabular}

Observa-se que os grupos R e RC e também a AT apresentam resultados da avaliação de competência predominantemente no nível 2 (atende), que corresponde ao esperado para o cargo. 
O grupo RC tem 30\% no nível 1 (em desenvolvimento) de competência e nenhum sujeito no nível 3 (supera), o que indica que há mais sujeitos em processo de desenvolvimento no cargo do que no grupo R. O grupo R tem 5\% dos sujeitos que superam o nível de competência.

A seguir, na figura 30, a representação gráfica do nível de competência.

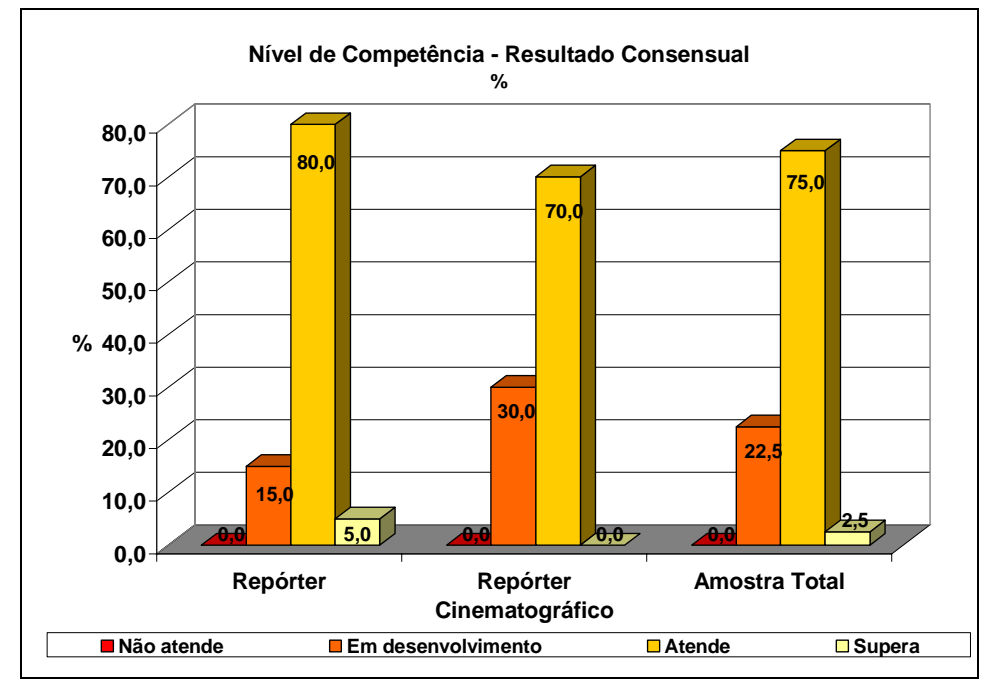

Figura 30. Distribuição dos níveis de competências.

A seguir, na tabela 57, aponta-se a distribuição das médias e o desvio padrão dos grupos R e RC e da AT.

Tabela 57: Distribuição das médias e desvio padrão da variável "nível de competência" nos grupos R e RC separadamente e na amostra total.

\begin{tabular}{lccc}
\hline Competência & Repórter & $\begin{array}{c}\text { Repórter } \\
\text { cinematográfico }\end{array}$ & $\begin{array}{c}\text { Amostra } \\
\text { total }\end{array}$ \\
\hline Média & 1,91 & 1,83 & 1,87 \\
$\begin{array}{l}\text { Desvio } \\
\text { padrão }\end{array}$ & 0,31 & 0,45 & 0,39 \\
$\mathbf{N}$ & $(20)$ & $(20)$ & $(40)$ \\
\hline
\end{tabular}

A média de pontuação da variável "competência" é maior no grupo R do que no grupo RC. 
Abaixo a comparação estatística entre os dois grupos quanto aos níveis de competência.

Tabela 58: Análise de significância para o nível de competência, considerando a amostra total de R e RC.

\begin{tabular}{llll}
\hline G & Mann Whitney U & p & Conclusão \\
\hline R/RC & 163,0 & 0,327 & NS \\
\hline
\end{tabular}

Os dois grupos concentram-se predominantemente no nível 2 (atende), não havendo diferença estatisticamente significante para o nível de competência. 


\section{DESEMPENHO}

A tabela 59 demonstra os resultados do nível de desempenho obtidos na amostra pesquisada, considerando os mesmos fatores analisados em relação ao nível de competência: NA - não atende, ED - em desenvolvimento, A - atende e S - supera. O resultado foi obtido através da avaliação final consensual entre avaliadores e sujeitos avaliados. Também foi utilizada a mesma escala anterior (competência) para a classificação do nível de desempenho: NA varia de 0 - 0,5; ED - de 0,6 a 1,5; A - de 1,6 a 2,5 e S - acima de 2,6.

Tabela 59: Distribuição do nível de desempenho nos grupos R e RC e na amostra total.

\begin{tabular}{lccc}
\hline Nível de desempenho & $\begin{array}{c}\text { Repórter } \\
\%\end{array}$ & $\begin{array}{c}\text { Repórter } \\
\text { cinematográfico } \\
\%\end{array}$ & $\begin{array}{c}\text { Amostra } \\
\text { total } \\
\%\end{array}$ \\
\hline Não atende (0) & 0,0 & 0,0 & 0,0 \\
Em desenvolvimento (1) & 5,0 & 10,0 & 7,5 \\
Atende (2) & 80,0 & 55,0 & 67,5 \\
Supera (3) & 15,0 & 35,0 & 25,0 \\
N & 20 & 20 & 40 \\
\hline
\end{tabular}

Os resultados do nível de desempenho demonstram que os grupos $\mathrm{R}$ e RC se concentram no nível 2 (atende). Se forem somados os índices do nível 3 (supera) e os do nível 2 (atende), os valores demonstram que a maioria dos sujeitos desempenha sua função de acordo com o padrão definido pela empresa, ficando $5 \%$ do grupo R e $10 \%$ do grupo RC abaixo do esperado.

A figura 31 demonstra essa distribuição.

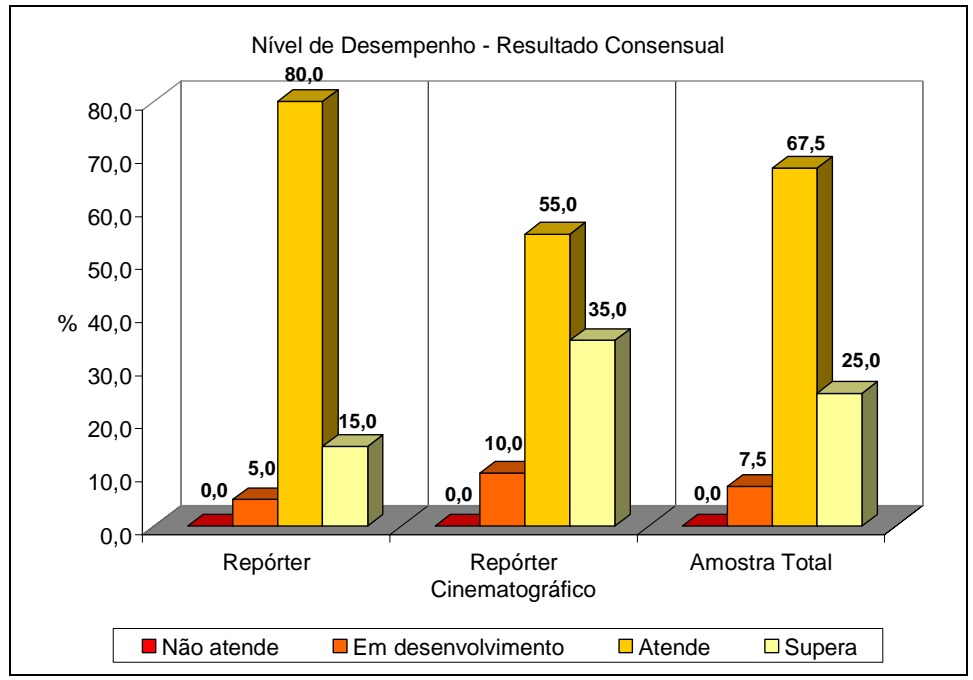

Figura 31. Distribuição dos níveis de desempenho. 
Na tabela 60, aponta-se a distribuição das médias e desvio padrão dos grupos R e RC e da AT.

Tabela 60: Distribuição das médias e desvio padrão da variável "desempenho" nos grupos R e RC separadamente e na amostra total.

\begin{tabular}{lccc}
\hline Desempenho & Repórter & $\begin{array}{c}\text { Repórter } \\
\text { cinematográfico }\end{array}$ & $\begin{array}{c}\text { Amostra } \\
\text { total }\end{array}$ \\
\hline Média & 2,06 & 2,32 & 2,19 \\
Desvio padrão & 0,44 & 0,42 & 0,44 \\
N & 20 & 20 & 40 \\
NívEL & ATENDE & ATENDE & ATENDE \\
& $(\mathbf{2})$ & $(\mathbf{2})$ & $(\mathbf{2})$ \\
\hline
\end{tabular}

A média de pontuação da variável "desempenho" é maior no grupo RC do que no grupo R.

Abaixo a comparação estatística entre os dois grupos quanto ao "nível de desempenho".

Tabela 61: Análise de significância para o nível de desempenho, considerando a amostra total de R e RC.

\begin{tabular}{llll}
\hline G & Mann Whitney $U$ & p & Conclusão \\
\hline R/RC & 170,5 & 0,429 & NS \\
\hline
\end{tabular}

Observa-se que o resultado do nível de desempenho não produz diferença estatisticamente significante entre os dois grupos. 
RESULTADOS - PARTE 3 MATRIZES DE INTERCORRELAÇÕES 


\section{PARTE 3 - MATRIZES DE INTERCORRELAÇÕES}

Nesta parte da avaliação dos resultados foram cruzados todos os dados (variáveis e fatores investigados), a fim de verificar as correlações significantes nesta pesquisa. Serão apresentadas três matrizes de intercorrelações, primeiramente considerando o grupo $\mathrm{R}$, em seguida o grupo $\mathrm{RC}$ e finalmente a AT, e descritos todos os resultados das análises significantes.

1 - Matriz de intercorrelação do grupo $\mathrm{R}$ - repórteres

2 - Matriz de intercorrelação do grupo RC - repórteres cinematográficos

3 - Matriz de intercorrelação dos dois grupos - amostra geral

As medidas utilizadas para medir as correlações entre as variáveis foram as seguintes:

- Coeficiente de correlação "r "de Pearson - utilizado para duas variáveis quantitativas;

- Coeficiente " $\varphi$ " - utilizado para duas variáveis nominais dicotômicas;

- Coeficiente "v" de Cramér - utilizado para uma variável nominal dicotômica e outra nominal não dicotômica;

- "T de Student" - para uma variável nominal dicotômica e outra quantitativa;

- "F" de Snedecor - para uma variável nominal não dicotômica e outra quantitativa.

As matrizes gerais com o cruzamento de todas as variáveis dos grupos R, RC e AT (significantes e não significantes) estão nos anexos 7,8 e 9 . 


\section{1- MATRIZ DE INTERCORRELAÇÃO - GRUPO R}

Todas as variáveis pesquisadas e correlacionadas entre si no grupo $\mathrm{R}$ estão apresentadas no anexo, perfazendo um total de 91 intercorrelações. Com base na análise estatística, vinte intercorrelações demonstraram ser estatisticamente significantes, o que pode ser observado na tabela 62 abaixo.

Tabela 62: Matriz de intercorrelação do grupo R

\begin{tabular}{|c|c|c|c|c|c|c|c|c|c|c|c|}
\hline $\begin{array}{c}\text { Matriz de } \\
\text { intercorrela- } \\
\text { ção grupo R }\end{array}$ & Idade & $\begin{array}{l}\text { № } \\
\text { filhos }\end{array}$ & $\begin{array}{l}\text { Tpo } \\
\text { empr }\end{array}$ & $\begin{array}{l}\text { Tpo } \\
\text { profis }\end{array}$ & $\begin{array}{c}\text { № } \\
\text { horas }\end{array}$ & $\begin{array}{l}\text { Pres. } \\
\text { stress }\end{array}$ & $\begin{array}{l}\text { Freq. } \\
\text { stress }\end{array}$ & $\begin{array}{l}\text { Intens. } \\
\text { stress }\end{array}$ & Competência & Desempenho & $\begin{array}{c}\text { Total } \\
- \\
\text { NBTA }\end{array}$ \\
\hline Sexo & $\begin{array}{l}t \\
=2,241 \\
p \\
=0,041\end{array}$ & & & & & & & & & $\begin{array}{c}t=2,988 \\
p=0,008\end{array}$ & \\
\hline Idade & & $\begin{array}{l}r=0 \\
789 \\
p=0,000\end{array}$ & $\begin{array}{l}r= \\
0,505 \\
p= \\
0,023\end{array}$ & $\begin{array}{l}r= \\
0,952 \\
p= \\
0,000\end{array}$ & & & & & $\begin{array}{l}r=0,580 \\
p=0,007\end{array}$ & $\begin{array}{l}r=0,591 \\
p=\quad 0,006\end{array}$ & \\
\hline Estado civil & & $\begin{array}{l}t=- \\
4,000 \\
p=0,001\end{array}$ & & & & & & & & & \\
\hline № filhos & & & $\begin{array}{l}r= \\
0,699 \\
p= \\
0,001\end{array}$ & $\begin{array}{l}r= \\
0,846 \\
p= \\
0,000\end{array}$ & & & & & $\begin{array}{l}r=0,682 \\
p=\quad 0,001\end{array}$ & $\begin{array}{l}r=0,652 \\
p=\quad 0,002\end{array}$ & \\
\hline $\begin{array}{l}\text { Tempo na } \\
\text { empresa }\end{array}$ & & & & & & & & & $\begin{array}{l}r=0,739 \\
p=\quad 0,000\end{array}$ & $\begin{array}{l}r=0,685 \\
p=\quad 0,001\end{array}$ & \\
\hline $\begin{array}{l}\text { Tempo de } \\
\text { profissão }\end{array}$ & & & & & & & & & $\begin{array}{l}r=0,592 \\
p=0,006\end{array}$ & $\begin{array}{l}r=0,606 \\
p=0,005\end{array}$ & \\
\hline $\begin{array}{l}\text { Presença } \\
\text { sintomas } \\
\text { stress }\end{array}$ & & & & & & & $\begin{array}{l}r= \\
0,503 \\
p= \\
0,024\end{array}$ & & & & \\
\hline $\begin{array}{l}\text { Freqüência } \\
\text { sintomas } \\
\text { stress }\end{array}$ & & & & & & & & $\begin{array}{l}r= \\
0,515 \\
p= \\
0,020\end{array}$ & & & $\begin{array}{l}r= \\
0,469 \\
p= \\
0,037\end{array}$ \\
\hline Competência & & & & & & & & & & $\begin{array}{l}r=0,864 \\
p=0,000\end{array}$ & \\
\hline
\end{tabular}


A seguir são analisados os resultados estatisticamente significantes da matriz de intercorrelação do grupo R.

\section{SEXO E IDADE}

A variável "idade" não apresentou resultados significantes se estudada separadamente, porém, quando analisada a correlação entre as variáveis "sexo" e "idade" no grupo R, encontramos resultados significantes. A tabela 63 ilustra que, nessa amostra, as mulheres apresentam menos idade que os homens, estando $100 \%$ na faixa de 20 a 40 anos, e que $100 \%$ dos homens concentram-se na faixa de 20 a 60 anos.

Tabela 63: Distribuição da correlação entre sexo e idade no grupo R

\begin{tabular}{|c|c|c|}
\hline Sexo $x$ Idade & $\begin{array}{c}\text { Masculino } \\
\%\end{array}$ & $\begin{array}{c}\text { Feminino } \\
\%\end{array}$ \\
\hline $20-30$ & 28 & 44 \\
\hline $31-40$ & 36 & 56 \\
\hline $41-50$ & 18 & 0 \\
\hline $51-60$ & 18 & 0 \\
\hline \multirow{2}{*}{} & 100 & 100 \\
\cline { 2 - 3 } & &
\end{tabular}

\section{SEXO E DESEMPENHO}

Ao analisar as variáveis "sexo" e "desempenho", verifica-se que há diferença entre os grupos masculino e feminino quanto ao desempenho. Os homens apresentam melhores resultados: 100\% atingiram nível $2(73 \%)$ e nível $3(27 \%)$ e não apresentaram resultados abaixo do esperado nível 1 (em desenvolvimento), conforme tabela 64. 11\% das mulheres apresentam nível 1 de desempenho.

Tabela 64: Distribuição da correlação entre sexo e desempenho no grupo R

\begin{tabular}{|l|c|c|}
\hline $\begin{array}{c}\text { Sexo x Nível de } \\
\text { Desempenho }\end{array}$ & $\begin{array}{c}\text { Masculino } \\
\%\end{array}$ & $\begin{array}{c}\text { Feminino } \\
\%\end{array}$ \\
\hline Não atende (0) & 0 & 0 \\
\hline Em desenvolvimento (1) & 0 & 11 \\
\hline Atende (2) & 73 & 89 \\
\hline Supera (3) & 27 & 0 \\
\hline $\mathrm{N}=20$ & 55 & 45 \\
\hline & 100 & 100 \\
\hline
\end{tabular}




\section{IDADE E NÚMERO DE FILHOS}

A correlação verificada entre idade e número de filhos no Grupo $R$ é considerada estatisticamente significante. $55 \%$ da amostra têm idade entre 24 e 40 anos e não têm filhos.

Tabela 65: Distribuição da correlação entre idade e número de filhos no grupo R (em \%)

\begin{tabular}{|l|r|r|r|r|}
\hline \multicolumn{1}{|c|}{ Idade $\mathbf{x}$ N. Filhos } & \multicolumn{1}{c|}{$\mathbf{0}$} & \multicolumn{1}{c|}{$\mathbf{1}$} & \multicolumn{1}{c|}{$\mathbf{2}$} & \multicolumn{1}{c|}{$\mathbf{3}$} \\
\hline $20-30$ anos & 35 & & & \\
\hline $31-40$ anos & 20 & 10 & 10 & \\
\hline $41-50$ anos & & & 5 & 5 \\
\hline $51-60$ anos & & 5 & 10 & \\
\hline$\%$ & 55 & 15 & 25 & 5 \\
\hline
\end{tabular}

\section{IDADE E TEMPO DE EMPRESA}

Verifica-se que o grupo R tem idade predominantemente na faixa de 24 a 40 anos (75\%) e pouco tempo de empresa (<1 a 10 anos), o que é evidenciado pela média de tempo, igual a 6,10 anos.

Tabela 66: Distribuição da correlação entre idade e tempo de empresa no grupo R (em \%)

\begin{tabular}{|l|r|r|r|r|}
\hline $\begin{array}{c}\text { Idade } \mathbf{x} \text { Tempo de } \\
\text { Empresa (anos) }\end{array}$ & $<\mathbf{- 5}$ & $\mathbf{6 - 1 0}$ & $\mathbf{1 1 - 2 0}$ & $\mathbf{2 1 - 3 0}$ \\
\hline $20-30$ anos & 30 & 5 & & \\
\hline $31-40$ anos & 15 & 25 & & \\
\hline $41-50$ anos & 5 & & & 5 \\
\hline $51-60$ anos & & 10 & 5 & \\
\hline$\%$ & 50 & 40 & 5 & 5 \\
\hline
\end{tabular}

\section{IDADE E TEMPO DE PROFISSÃO}

O grupo é relativamente jovem (75\% tem 20-40 anos), com média de idade de 36,5 anos, e tem elevado tempo de profissão, média de 14,7 anos. Observa-se porém que 50\% dos sujeitos têm menos de 10 anos de profissão.

Tabela 67: Distribuição da correlação entre idade e tempo de empresa no grupo R (em \%)

\begin{tabular}{|l|r|r|r|r|}
\hline $\begin{array}{c}\text { Idade } \mathbf{x} \text { Tempo de } \\
\text { Profissão (anos) }\end{array}$ & $\mathbf{3 - 1 0}$ & $\mathbf{1 1 - 2 0}$ & $\mathbf{2 1 - 3 0}$ & $\mathbf{3 1 - 4 0}$ \\
\hline $20-30$ anos & 35 & & & \\
\hline $31-40$ anos & 15 & 25 & & \\
\hline $41-50$ anos & & & 10 & \\
\hline $51-60$ anos & & 5 & 5 & 5 \\
\hline$\%$ & 50 & 30 & 15 & 5 \\
\hline
\end{tabular}




\section{IDADE E COMPETÊNCIA}

15\% dos repórteres entre 20 e 30 anos de idade apresentam competência no nível 1 . Os outros níveis de competência são distribuídos pelas outras faixas etárias, como observado na tabela 68 .

Tabela 68: Distribuição da correlação entre idade e competência no grupo R (em \%)

\begin{tabular}{|l|r|r|r|r|}
\hline $\begin{array}{l}\text { Idade x Níveis de } \\
\text { Competência }\end{array}$ & $0(\mathrm{NA})$ & $1(\mathrm{ED})$ & $2(\mathrm{~A})$ & $3(\mathrm{~S})$ \\
\hline $20-30$ anos & & 15 & 20 & \\
\hline $31-40$ anos & & & 40 & \\
\hline $41-50$ anos & & & 5 & 5 \\
\hline $51-60$ anos & & & 15 & \\
\hline$\%$ & & 15 & 80 & 5 \\
\hline
\end{tabular}

\section{IDADE E DESEMPENHO}

Repórteres na faixa de idade entre 20 e 30 (5\%) são os que apresentaram nível 1, indicativo de nível baixo de desempenho (ED); os que revelam nível 3 (S) têm idade entre 38 e 60 anos, conforme demonstra a tabela 69.

Tabela 69: Distribuição da correlação entre idade e desempenho no grupo R (em \%)

\begin{tabular}{|l|r|r|r|r|}
\hline $\begin{array}{l}\text { Idade x Níveis de } \\
\text { Desempenho }\end{array}$ & $0(\mathrm{NA})$ & $1(\mathrm{ED})$ & $2(\mathrm{~A})$ & $3(\mathrm{~S})$ \\
\hline $20-30$ anos & & 5 & 30 & \\
\hline $31-40$ anos & & & 35 & 5 \\
\hline $41-50$ anos & & & 5 & 5 \\
\hline $51-60$ anos & & & 10 & 5 \\
\hline$\%$ & & 5 & 80 & 15 \\
\hline
\end{tabular}

\section{ESTADO CIVIL E NÚMERO DE FILHOS}

O grupo R tem média de 0,8 filhos e 55\% da amostra se caracteriza por não ter filhos, o que se observa na tabela 70 .

Tabela 70: Distribuição da correlação entre estado civil e número de filhos no grupo R (em \%)

\begin{tabular}{|l|c|c|c|c|}
\hline \multirow{2}{*}{ Estado civil } & \multicolumn{4}{|c|}{ Grupo R - Número de filhos } \\
\cline { 2 - 5 } & Nenhum & 1 & 2 & 3 \\
\hline $\begin{array}{l}\text { Solteiros + } \\
\text { separados }\end{array}$ & 25 & 0 & 0 & 0 \\
\hline $\begin{array}{l}\text { Casados + } \\
\text { vivem } \\
\text { maritalmente }\end{array}$ & 30 & 15 & 25 & 5 \\
\hline$\%$ & 55 & 15 & 25 & 5 \\
\hline
\end{tabular}




\section{NÚMERO DE FILHOS E TEMPO DE EMPRESA}

A média do número de filhos, como analisado anteriormente, é baixa $(0,8)$, como também é baixa a média do tempo na empresa atual, que fica em 6,10 anos.

Tabela 71: Distribuição da correlação entre número de filhos e tempo de profissão no grupo R (em \%)

\begin{tabular}{|l|c|c|c|c|}
\hline \multirow{2}{*}{$\begin{array}{c}\text { Tempo de } \\
\text { Empresa }\end{array}$} & \multicolumn{4}{|c|}{ Grupo R - Número de filhos } \\
\cline { 2 - 5 } & Nenhum & 1 & 2 & 3 \\
\hline$<1-5$ anos & 40 & & 10 & \\
\hline $6-10$ anos & 15 & 15 & 10 & \\
\hline $11-20$ anos & & & 5 & \\
\hline $21-30$ anos & & & & 5 \\
\hline$\%$ & 55 & 15 & 25 & 5 \\
\hline
\end{tabular}

\section{NÚMERO DE FILHOS E TEMPO DE PROFISSÃO}

A correlação significante entre número de filhos e tempo de profissão revela que os repórteres com menos tempo de profissão são os que têm menos filhos. A tabela 72 indica que, à medida que aumenta o tempo de profissão, aumenta o número de filhos.

Tabela 72: Distribuição da correlação entre número de filhos e tempo de profissão no grupo R (em \%)

\begin{tabular}{|l|c|c|c|c|}
\hline \multirow{2}{*}{$\begin{array}{c}\text { Tempo de } \\
\text { profissão }\end{array}$} & \multicolumn{4}{|c|}{ Grupo R - Número de filhos } \\
\cline { 2 - 5 } & Nenhum & 1 & 2 & 3 \\
\hline $3-10$ anos & 50 & & & \\
\hline $11-20$ anos & 5 & 15 & 10 & \\
\hline $21-30$ anos & & & 10 & 5 \\
\hline $31-40$ anos & & & 5 & \\
\hline$\%$ & 55 & 15 & 25 & 5 \\
\hline
\end{tabular}

\section{NÚMERO DE FILHOS E COMPETÊNCIA}

Os sujeitos que apresentam competência no nível 1 e estão em processo de desenvolvimento no cargo são também os que não têm filhos (15\%). Os resultados demonstram que $40 \%$ têm nível 2 de competência e não tem filhos.

Tabela 73: Distribuição da correlação entre número de filhos e competência no grupo R (em \%)

\begin{tabular}{|l|r|r|r|r|}
\hline N. Filhos x Competência & $0(\mathrm{NA})$ & $1(\mathrm{ED})$ & $2(\mathrm{~A})$ & $3(\mathrm{~S})$ \\
\hline Nenhum & & 15 & 40 & \\
\hline 1 & & & 15 & \\
\hline 2 & & & 25 & \\
\hline 3 & & & & 5 \\
\hline$\%$ & & 15 & 80 & 5 \\
\hline
\end{tabular}




\section{NÚMERO DE FILHOS E DESEMPENHO}

Os sujeitos com nível de desempenho 2 são 50\% da amostra (atendem plenamente) e também não têm filhos. Os que superam em desempenho (nível 3) têm mais filhos.

Tabela 74: Distribuição da correlação entre número de filhos e desempenho no grupo R (em \%)

\begin{tabular}{|l|r|r|r|r|}
\hline N. Filhos x Desempenho & O(NA) & $1(\mathrm{ED})$ & $2(\mathrm{~A})$ & $3(\mathrm{~S})$ \\
\hline Nenhum & & 5 & 50 & \\
\hline 1 & & & 15 & \\
\hline 2 & & & 15 & 10 \\
\hline 3 & & & & 5 \\
\hline$\%$ & & 5 & 80 & 15 \\
\hline
\end{tabular}

\section{TEMPO DE EMPRESA E COMPETÊNCIA}

Observa-se na tabela 75 que $10 \%$ dos sujeitos têm menos de 5 anos de empresa e apresentam menor nível de competência e que 5\% dos sujeitos com maior tempo de empresa (de 21 a 30 anos) são os que revelam melhores resultados - nível 3.

Tabela 75: Distribuição da correlação entre tempo de empresa e competência no grupo R (em \%)

\begin{tabular}{|l|r|r|r|r|}
\hline $\begin{array}{l}\text { Tempo de empresa } \\
\text { e Competência }\end{array}$ & 0(NA) & 1(ED) & $2(\mathrm{~A})$ & $3(\mathrm{~S})$ \\
\hline$<1-5$ anos & & 10 & 45 & \\
\hline $6-10$ anos & & 5 & 30 & \\
\hline $11-20$ anos & & & 5 & \\
\hline $21-30$ anos & & & & 5 \\
\hline$\%$ & & 15 & 80 & 5 \\
\hline
\end{tabular}

\section{TEMPO DE EMPRESA E DESEMPENHO}

A maior parte do grupo R (80\%) apresenta nível 2 (atende) de desempenho. Sujeitos com pouco tempo de empresa (5\%) são os que revelam menor nível de desempenho - nível 1 (ED).

Tabela 76: Distribuição da correlação entre tempo de empresa e desempenho no grupo R (em \%)

\begin{tabular}{|l|r|r|r|r|}
\hline Tempo de empresa $x$ Desempenho & $0(\mathrm{NA})$ & $1(\mathrm{ED})$ & $2(\mathrm{~A})$ & $3(\mathrm{~S})$ \\
\hline$<1-5$ anos & & 5 & 45 & \\
\hline $6-10$ anos & & & 30 & 10 \\
\hline $11-20$ anos & & & 5 & \\
\hline $21-30$ anos & & & & 5 \\
\hline$\%$ & & 5 & 80 & 15 \\
\hline
\end{tabular}




\section{TEMPO DE PROFISSÃO E COMPETÊNCIA}

15\% dos sujeitos com menor tempo de profissão (menos de 10 anos) apresentam nível de competência abaixo do esperado (nível 1) e 5\% dos sujeitos mais experientes (de 21 a 30 anos) apresentam maior nível de competência (nível 3).

Tabela 77: Distribuição da correlação entre tempo de profissão e competência no grupo R (em \%)

\begin{tabular}{|l|r|r|r|r|}
\hline Tempo de profissão $x$ Competência & $0(\mathrm{NA})$ & $1(\mathrm{ED})$ & $2(\mathrm{~A})$ & $3(\mathrm{~S})$ \\
\hline$<1-10$ anos & & 15 & 35 & \\
\hline $11-20$ anos & & & 30 & \\
\hline $21-30$ anos & & & 10 & 5 \\
\hline $31-40$ anos & & 15 & 5 & 80 \\
\hline$\%$ & & & 5 \\
\hline
\end{tabular}

\section{TEMPO DE PROFISSÃO E DESEMPENHO}

Cinco por cento (5\%) dos sujeitos com menor tempo de profissão apresentam nível de desempenho abaixo do esperado (nível 1) e 80\% dos sujeitos com mais de 11 anos de experiência apresentam maior nível de desempenho (nível 3).

Tabela 78: Distribuição da correlação entre tempo de profissão e desempenho no grupo R (em \%)

\begin{tabular}{|l|l|r|r|r|}
\hline Tempo de profissão $x$ Desempenho & O(NA) & $1(\mathrm{ED})$ & $2(\mathrm{~A})$ & $3(\mathrm{~S})$ \\
\hline$<1-10$ anos & & 5 & 45 & \\
\hline $11-20$ anos & & & 25 & 5 \\
\hline $21-30$ anos & & & 10 & 5 \\
\hline $31-40$ anos & & & & 5 \\
\hline$\%$ & & 5 & 80 & 15 \\
\hline
\end{tabular}

\section{PRESENÇA E FREQÜÊNCIA DE SINTOMAS DE STRESS}

As variáveis "presença" (nível de baixo a altíssimo) e "frequiência de sintomas de stress" (nível de baixo a alto) não apresentaram resultados significantes quando estudadas isoladamente no grupo R, porém, se analisada a correlação entre elas, os resultados são estatisticamente significantes. No grupo R, 50\% apresentaram nível altíssimo de presença de sintomas de stress, apesar de o nível de freqüência ser médio (2) e médio-alto (3). 
Tabela 79: Correlação entre presença e frequiência de sintomas de stress no grupo R (em \%)

\begin{tabular}{|l|l|r|r|l|}
\hline $\begin{array}{l}\text { Presença x Freqüência de } \\
\text { Sintomas de Stress }\end{array}$ & Baixo (1) & Médio (2) & \multicolumn{1}{|c|}{$\begin{array}{c}\text { Médio-Alto } \\
\text { (3) }\end{array}$} & Alto (4) \\
\hline Baixo (1) & & & & \\
\hline Médio (2) & & 15 & & \\
\hline Médio-Alto (3) & & & & \\
\hline Alto (4) & & 35 & & \\
\hline Altíssimo (5) & & 35 & 15 & \\
\hline$\%$ & & 85 & 15 & \\
\hline
\end{tabular}

\section{FREQÜENCIA E INTENSIDADE DE SINTOMAS DE STRESS}

Conforme observado na matriz, a intercorrelação entre a frequiência e a intensidade de sintomas de stress é considerada significante. A análise estatística indica que o nível de intensidade dos sintomas no grupo R é médio alto, apesar de o nível de frequiência ser médio.

Tabela 80: Correlação entre frequiência e intensidade de sintomas de stress no grupo R (em \%)

\begin{tabular}{|l|l|r|r|r|}
\hline $\begin{array}{l}\text { Freqüência x Intensidade } \\
\text { de Sintomas de Stress }\end{array}$ & Baixo (1) & \multicolumn{1}{|c|}{ Médio (2) } & $\begin{array}{c}\text { Médio-Alto } \\
\text { (3) }\end{array}$ & Alto (4) \\
\hline Baixo (1) & & 5 & & \\
\hline Médio (2) & & 35 & 40 & 5 \\
\hline Médio-Alto (3) & & & 10 & 5 \\
\hline Alto (4) & & & & \\
\hline$\%$ & & 40 & 50 & 10 \\
\hline
\end{tabular}

\section{FREQÜÊNCIA DE SINTOMAS DE STRESS E COMPORTAMENTO TIPO A}

Observa-se que o grupo $\mathrm{R}$ apresenta nível alto de comportamento tipo $\mathrm{A}$ e que o nível de frequiência de sintomas de stress é médio. Tal correlação é estatisticamente significante.

Tabela 81: Correlação entre freqüência de sintomas de stress e comportamento tipo A no grupo R (em \%)

\begin{tabular}{|l|l|r|r|r|r|}
\hline $\begin{array}{l}\text { Freqüência de Sintomas de } \\
\text { Stress x Compto Tipo A }\end{array}$ & Baixo & \multicolumn{1}{|c|}{$\begin{array}{l}\text { Baixo- } \\
\text { Médio }\end{array}$} & \multicolumn{1}{|c|}{ Médio } & \multicolumn{1}{|c|}{ Alto } & Altíssimo \\
\hline Baixo (1) & & & 5 & & \\
\hline Médio (2) & & & 20 & 45 & 15 \\
\hline Médio-Alto (3) & & & & 5 & 10 \\
\hline Alto (4) & & & & & \\
\hline$\%$ & & & 25 & 50 & 25 \\
\hline
\end{tabular}




\section{COMPETÊNCIA E DESEMPENHO}

Os resultados do grupo $\mathrm{R}$ indicam que o nível de desempenho está diretamente correlacionado com o nível de competência dos sujeitos: 70\% dos sujeitos que apresentam nível 2 de competência (atendem plenamente) também apresentam nível 2 ou nível 3 de desempenho (atendem ou superam).

Tabela 82: Distribuição da correlação entre competência e desempenho no grupo R (em \%)

\begin{tabular}{|l|r|r|r|r|}
\hline Competência x Desempenho & $0(\mathrm{NA})$ & $1(\mathrm{ED})$ & $2(\mathrm{~A})$ & $3(\mathrm{~S})$ \\
\hline $0(\mathrm{NA})$ & & & & \\
\hline $1(\mathrm{ED})$ & & 5 & 10 & \\
\hline $2(\mathrm{~A})$ & & & 70 & 10 \\
\hline $3(\mathrm{~S})$ & & & & 5 \\
\hline$\%$ & & 5 & 80 & 15 \\
\hline
\end{tabular}




\section{2- MATRIZ DE INTERCORRELAÇÃO - GRUPO RC}

No anexo 10 são apresentadas todas as variáveis pesquisadas e correlacionadas no grupo RC, totalizando 91 intercorrelações. Na tabela 83 é demonstrada a matriz de intercorrelação do grupo RC e são apresentadas as quinze intercorrelações estatisticamente significantes.

Tabela 83: Matriz de intercorrelação do grupo RC

\begin{tabular}{|c|c|c|c|c|c|c|c|c|c|}
\hline $\begin{array}{l}\text { Matriz de } \\
\text { intercorrelação } \\
\text { Grupo RC }\end{array}$ & $\begin{array}{l}\text { № } \\
\text { filhos }\end{array}$ & $\begin{array}{l}\text { Tpo } \\
\text { empr }\end{array}$ & $\begin{array}{l}\text { Tpo } \\
\text { profis }\end{array}$ & $\begin{array}{c}\text { № } \\
\text { horas }\end{array}$ & $\begin{array}{l}\text { Pres. } \\
\text { sint. } \\
\text { stress }\end{array}$ & $\begin{array}{l}\text { Frequ.sint. } \\
\text { stress }\end{array}$ & $\begin{array}{l}\text { Intens. } \\
\text { stress }\end{array}$ & Desempenho & $\begin{array}{c}\text { Total } \\
- \\
\text { NBTA }\end{array}$ \\
\hline Idade & $\begin{array}{l}r= \\
0,513 \\
p=0,021\end{array}$ & $\begin{array}{l}r \\
=0,760 \\
p=0,000\end{array}$ & $\begin{array}{l}r \\
=0,865 \\
p=0,000\end{array}$ & $\begin{array}{l}r=- \\
0,538 \\
p=0,018\end{array}$ & & & & & \\
\hline Estado civil & $\begin{array}{l}t=- \\
9,675 \\
p \\
=0,000\end{array}$ & & & & & & & & \\
\hline № filhos & & $\begin{array}{l}r= \\
0,539 \\
p= \\
0,014\end{array}$ & & & & & & & \\
\hline Escolaridade & & & & $\begin{array}{l}t=2,513 \\
p= \\
0,027\end{array}$ & & & & & \\
\hline $\begin{array}{l}\text { Tempo de } \\
\text { empresa }\end{array}$ & & & $\begin{array}{l}r= \\
0,721 \\
p= \\
0,000\end{array}$ & & $\begin{array}{l}r \\
=0,479 \\
p= \\
0,033\end{array}$ & & & & $\begin{array}{l}r= \\
0,568 \\
p= \\
0,009\end{array}$ \\
\hline № horas & & & & & & & & & $\begin{array}{l}r=- \\
0,466 \\
p= \\
0,044\end{array}$ \\
\hline $\begin{array}{l}\text { Presença } \\
\text { sintomas } \\
\text { stress }\end{array}$ & & & & & & $\begin{array}{l}r=0,553 \\
p=0,011\end{array}$ & $\begin{array}{l}r= \\
0,575 \\
p= \\
0,008\end{array}$ & & \\
\hline $\begin{array}{l}\text { Freqüência } \\
\text { sintomas } \\
\text { stress }\end{array}$ & & & & & & & $\begin{array}{l}r= \\
0,790 \\
p= \\
0,000\end{array}$ & & \\
\hline $\begin{array}{l}\text { Intensidade } \\
\text { sintomas } \\
\text { stress }\end{array}$ & & & & & & & & & \\
\hline Competência & & & & & & & & $\begin{array}{l}r=0,827 \\
p=0,000\end{array}$ & \\
\hline Total - NBTA & & & & & & & & & \\
\hline
\end{tabular}


Abaixo são analisados os resultados estatisticamente significantes da matriz de intercorrelação do grupo RC.

\section{IDADE E NÚMERO DE FILHOS}

No grupo RC se verifica que a média de idade é elevada (40,7 anos), com variação de 22 a 52 anos. A maioria (70\%) tem filhos - média de 1,4 filhos.

Tabela 84: Distribuição da correlação entre idade e número de filhos no grupo RC (em \%)

\begin{tabular}{|l|r|r|r|r|}
\hline \multicolumn{1}{|c|}{ Idade $\mathbf{x}$ N. Filhos } & \multicolumn{1}{|c|}{$\mathbf{0}$} & $\mathbf{1}$ & $\mathbf{2}$ & \multicolumn{1}{|c|}{$\mathbf{3}$} \\
\hline $20-30$ anos & 15 & & 5 & \\
\hline $31-40$ anos & 10 & 10 & 10 & \\
\hline $41-50$ anos & 5 & 5 & 25 & 5 \\
\hline $51-60$ anos & & & 10 & \\
\hline$\%$ & 30 & 15 & 50 & 5 \\
\hline
\end{tabular}

\section{IDADE E TEMPO DE EMPRESA}

Observa-se que o grupo RC apresenta média de idade igual a 40,7 anos e média de tempo de empresa igual a 13 anos, que podemos considerar médias elevadas. $40 \%$ tem menos de 5 anos de empresa.

Tabela 85: Correlação entre idade e tempo de empresa no grupo RC (em \%)

\begin{tabular}{|l|r|r|r|r|r|}
\hline $\begin{array}{c}\text { Idade } \mathbf{x} \text { Tempo de } \\
\text { Empresa (anos) }\end{array}$ & $<\mathbf{1 - 5}$ & $\mathbf{6 - 1 0}$ & $\mathbf{1 1 - 2 0}$ & $\mathbf{2 1 - 3 0}$ & $\mathbf{3 1 - 4 0}$ \\
\hline $20-30$ anos & 20 & & & & \\
\hline $31-40$ anos & 15 & 10 & 5 & & \\
\hline $41-50$ anos & 5 & 10 & 5 & 15 & 5 \\
\hline $51-60$ anos & & & & & 10 \\
\hline$\%$ & 40 & 20 & 10 & 15 & 15 \\
\hline
\end{tabular}

\section{IDADE E TEMPO DE PROFISSÃO}

A correlação existente entre essas duas variáveis é significante no grupo RC. Constatamos que o tempo médio de profissão é elevado (19,05 anos), bem como a média de idade do grupo (40,7 anos). 
Tabela 86: Correlação entre idade e tempo de profissão no grupo RC (em \%)

\begin{tabular}{|l|c|r|r|r|}
\hline $\begin{array}{c}\text { Idade x Tempo de } \\
\text { Profissão (anos) }\end{array}$ & $\mathbf{3 - 1 0}$ & $\mathbf{1 1 - 2 0}$ & $\mathbf{2 1 - 3 0}$ & $\mathbf{3 1 - 4 0}$ \\
\hline $20-30$ anos & 20 & & & \\
\hline $31-40$ anos & & 30 & & \\
\hline $41-50$ anos & & 10 & 25 & 5 \\
\hline $51-60$ anos & & & & 10 \\
\hline$\%$ & 20 & 40 & 25 & 15 \\
\hline
\end{tabular}

\section{IDADE E NÚMERO DE HORAS DE TRABALHO/DIA}

Os dados revelam correlação significante entre as variáveis "idade" e "número de horas de trabalho/dia" e indicam que a média de idade é elevada (40,7 anos) e que o grupo trabalha em média 7,58 horas por dia. $80 \%$ do grupo trabalham de 7 a $8 \mathrm{hs} /$ dia e os mais jovens de idade são os que trabalham mais horas.

Tabela 87: Correlação entre idade e n. de horas no grupo RC (em \%)

\begin{tabular}{|l|r|r|r|r|}
\hline \multicolumn{1}{|c|}{ Idade $\mathbf{x}$ N.Horas } & \multicolumn{1}{|c|}{$\mathbf{7 - 8}$} & $\mathbf{9}$ & \multicolumn{1}{c|}{$\mathbf{1 0}$} & \multicolumn{1}{c|}{$>\mathbf{1 0}$} \\
\hline $20-30$ anos & 10 & & 2 & \\
\hline $31-40$ anos & 20 & 2 & & \\
\hline $41-50$ anos & 40 & & & \\
\hline $51-60$ anos & 10 & & & \\
\hline$\%$ & 80 & 10 & 10 & 0 \\
\hline
\end{tabular}

\section{ESTADO CIVIL E NÚMERO DE FILHOS}

Nesse grupo, $85 \%$ são casados/vivem maritalmente e $80 \%$ têm filhos (média 1,4), correlação que é estatisticamente significante

Tabela 88: Correlação entre estado civil e número de filhos no grupo RC (em \%)

\begin{tabular}{|l|c|c|c|c|}
\hline \multirow{2}{*}{ Estado civil } & \multicolumn{4}{|c|}{ Grupo R - Número de filhos } \\
\cline { 2 - 5 } & Nenhum & 1 & 2 & 3 \\
\hline $\begin{array}{l}\text { Solteiros + } \\
\text { separados }\end{array}$ & 15 & & & \\
\hline $\begin{array}{l}\text { Casados + } \\
\text { vivem } \\
\text { maritalmente }\end{array}$ & 5 & 25 & 50 & 5 \\
\hline$\%$ & 20 & 25 & 50 & 5 \\
\hline
\end{tabular}




\section{NÚMERO DE FILHOS E TEMPO DE EMPRESA}

Os resultados indicam que tanto a média de filhos $(1,4)$ quanto o tempo de empresa (13 anos) são elevados. $65 \%$ dos RC têm mais de 6 anos de empresa e $55 \%$ deles têm filhos.

Tabela 89: Correlação entre número de filhos e tempo de empresa no grupo RC (em \%)

\begin{tabular}{|l|l|l|l|l|}
\hline \multirow{2}{*}{$\begin{array}{l}\text { Tempo de } \\
\text { Empresa }\end{array}$} & \multicolumn{4}{|l|}{ Grupo R - Número de filhos } \\
\cline { 2 - 5 } & Nenhum & 1 & 2 & 3 \\
\hline$<1-5$ anos & 10 & 20 & 5 & \\
\hline $6-10$ anos & 5 & 5 & 10 & \\
\hline $11-20$ anos & 5 & & 5 & \\
\hline $21-30$ anos & & & 10 & 5 \\
\hline $31-40$ anos & & & 20 & \\
\hline$\%$ & 20 & 25 & 50 & 5 \\
\hline
\end{tabular}

\section{ESCOLARIDADE E NÚMERO DE HORAS}

A maioria do grupo (70\%) apresenta $2^{\circ}$ grau completo e/ou superior incompleto e trabalha em média 7,58 h/dia, resultados considerados estatisticamente significantes.

Tabela 90: Correlação entre escolaridade e n.horas no grupo RC (em \%)

\begin{tabular}{|l|r|r|r|r|}
\hline \multicolumn{1}{|c|}{ Escolaridade x N.Horas } & $\mathbf{7 - 8}$ & \multicolumn{1}{|c|}{$\mathbf{9}$} & \multicolumn{1}{c|}{$\mathbf{1 0}$} & \multicolumn{1}{c|}{$>\mathbf{1 0}$} \\
\hline $\begin{array}{l}2^{\circ} \text { grau + superior } \\
\text { incompleto }\end{array}$ & 50 & 10 & 10 & \\
\hline Superior + pós-graduação & 30 & & & \\
\hline$\%$ & 80 & 10 & 10 & 0 \\
\hline
\end{tabular}

\section{TEMPO DE EMPRESA E TEMPO DE PROFISSÃO}

Tanto a média de tempo na empresa atual (13 anos) quanto a média do tempo de profissão (19,05 anos) são elevadas.

Tabela 91: Correlação entre tempo de empresa e de profissão no grupo RC (em \%)

\begin{tabular}{|l|r|r|r|r|}
\hline $\begin{array}{l}\text { Tempo de empresa x Tempo de } \\
\text { Profissão (em anos) }\end{array}$ & $\mathbf{3 - 1 0}$ & $\mathbf{1 1}-\mathbf{2 0}$ & $\mathbf{2 1}-\mathbf{3 0}$ & $\mathbf{3 1}-\mathbf{4 0}$ \\
\hline$<1-5$ anos & 25 & 15 & 5 & \\
\hline $6-10$ anos & & 5 & 10 & \\
\hline $11-20$ anos & & 5 & 5 & \\
\hline $21-30$ anos & & 10 & 5 & \\
\hline $31-40$ anos & 25 & 35 & 25 & 15 \\
\hline$\%$ & & & & 15 \\
\hline
\end{tabular}




\section{TEMPO DE EMPRESA E PRESENÇA DE SINTOMAS DE STRESS}

Conforme observado, há correlação significante entre essas duas variáveis. O grupo RC tem uma média elevada de tempo na empresa atual (13 anos) e uma média alta de presença de sintomas de stress (nível 4). O nível de presença de sintomas de stress é mais elevado nos RCs que têm mais tempo de empresa.

Tabela 92: Correlação entre tempo de empresa e presença de sintomas de stress no grupo RC (em \%)

\begin{tabular}{|l|r|r|r|r|r|}
\hline $\begin{array}{l}\text { Tempo de empresa x Presença de } \\
\text { Sintoma de Stress }\end{array}$ & Baixo (1) & Médio(2) & $\begin{array}{r}\text { Médio- } \\
\text { Alto (3) }\end{array}$ & Alto (4) & $\begin{array}{c}\text { Altíssimo } \\
\text { (5) }\end{array}$ \\
\hline$<1-5$ anos & & 25 & & 15 & \\
\hline $6-10$ anos & & & & 10 & 10 \\
\hline $11-20$ anos & & & & & 10 \\
\hline $21-30$ anos & & 5 & & 10 & \\
\hline $31-40$ anos & 0 & 30 & 0 & 40 & 30 \\
\hline$\%$ & & & & 5 & 10 \\
\hline
\end{tabular}

\section{TEMPO DE EMPRESA E COMPORTAMENTO TIPO A}

Também se verifica que a média de tempo de empresa do grupo RC é elevada (13 anos), bem como a média do padrão de comportamento tipo A, com resultados no nível alto (média 69,4).

Tabela 93: Correlação entre tempo de empresa e comportamento tipo A no grupo RC (em \%)

\begin{tabular}{|l|r|r|r|r|r|}
\hline $\begin{array}{l}\text { Tempo de empresa } \mathbf{x} \\
\text { Comportamento Tipo A }\end{array}$ & Baixo & \multicolumn{1}{c|}{$\begin{array}{c}\text { Baixo- } \\
\text { Médio }\end{array}$} & \multicolumn{1}{c|}{ Médio } & \multicolumn{1}{c|}{ Alto } & Altíssimo \\
\hline$<1-5$ anos & & 5 & 10 & 25 & \\
\hline $6-10$ anos & & & 5 & 15 & \\
\hline $11-20$ anos & & & & 10 & \\
\hline $21-30$ anos & & & & 10 & 5 \\
\hline $31-40$ anos & & & & 10 & 5 \\
\hline$\%$ & 0 & 5 & 15 & 70 & 10 \\
\hline
\end{tabular}

\section{NÚMERO DE HORAS TRABALHADAS E COMPORTAMENTO TIPO A}

$\mathrm{O}$ grupo $\mathrm{RC}$ trabalha em média 7,58 h/dia e apresenta padrão de comportamento tipo A alto (80\% entre alto e altíssimo).

Tabela 94: Correlação entre n. horas e comportamento tipo A no grupo RC (em \%)

\begin{tabular}{|c|c|c|c|c|c|}
\hline N. Horas $x$ Comportamento Tipo A & Baixo & $\begin{array}{l}\text { Baixo- } \\
\text { Médio }\end{array}$ & Médio & Alto & Altíssimo \\
\hline $7-8$ & & 5 & 5 & 60 & 10 \\
\hline 9 & & & 5 & 5 & \\
\hline 10 & & & 5 & 5 & \\
\hline$>10$ & & & & & \\
\hline$\%$ & 0 & 5 & 15 & 70 & 10 \\
\hline
\end{tabular}




\section{PRESENÇA E FREQÜÊNCIA DE SINTOMAS DE STRESS}

O nível de presença de sintomas de stress é alto (nível 4) e o nível de frequiência no grupo RC é médio (2).

Tabela 95: Correlação entre presença e freqüência de sintomas de stress no grupo RC (em \%)

\begin{tabular}{|l|r|r|r|r|}
\hline $\begin{array}{l}\text { Presença x Freqüência de } \\
\text { Sintomas de Stress }\end{array}$ & \multicolumn{1}{|c|}{ Baixo (1) } & Médio (2) & \multicolumn{1}{c|}{$\begin{array}{c}\text { Médio-Alto } \\
\text { (3) }\end{array}$} & Alto (4) \\
\hline Baixo (1) & & & & \\
\hline Médio (2) & 10 & 20 & & \\
\hline Médio-Alto (3) & 10 & & & \\
\hline Alto (4) & 5 & 25 & 5 & \\
\hline Altíssimo (5) & 25 & 65 & & 5 \\
\hline$\%$ & \multicolumn{4}{|r|}{} \\
\hline
\end{tabular}

\section{PRESENÇA E INTENSIDADE DE SINTOMAS DE STRESS}

Da mesma maneira que na análise do grupo $\mathrm{R}$, é considerada estatisticamente significante a correlação entre nível de presença de sintomas de stress alto (nível 4) e nível de intensidade de stress médio (nível 2) para o grupo RC.

Tabela 96: Correlação entre presença e intensidade de sintomas de stress no grupo RC (em \%)

\begin{tabular}{|l|r|r|r|r|}
\hline $\begin{array}{l}\text { Presença x Intensidade de } \\
\text { Sintomas de Stress }\end{array}$ & Baixo (1) & Médio (2) & $\begin{array}{c}\text { Médio-Alto } \\
\text { (3) }\end{array}$ & Alto (4) \\
\hline Baixo (1) & 5 & & & \\
\hline Médio (2) & 5 & & \\
\hline Médio-Alto (3) & & & & \\
\hline Alto (4) & 10 & 10 & 5 & \\
\hline Altíssimo (5) & 15 & 70 & 5 & 5 \\
\hline$\%$ & & & 10 & 5 \\
\hline
\end{tabular}

\section{FREQÜÊNCIA E INTENSIDADE DE SINTOMAS DE STRESS}

Os níveis de freqüência e de intensidade de sintomas de stress apresentam resultados semelhantes, ambos estando no nível médio (2).

Tabela 97: Correlação entre freqüência e intensidade de sintomas de stress no grupo RC (em \%)

\begin{tabular}{|l|r|r|r|r|}
\hline $\begin{array}{l}\text { Freqüência x Intensidade } \\
\text { de Sintomas de Stress }\end{array}$ & \multicolumn{1}{|c|}{ Baixo (1) } & Médio (2) & \multicolumn{1}{|c|}{$\begin{array}{c}\text { Médio-Alto } \\
\text { (3) }\end{array}$} & Alto (4) \\
\hline Baixo (1) & 5 & 20 & & \\
\hline Médio (2) & 10 & 45 & 10 & \\
\hline Médio-Alto (3) & & 5 & & \\
\hline Alto (4) & & & & 5 \\
\hline$\%$ & 15 & 70 & 10 & 5 \\
\hline
\end{tabular}




\section{COMPETÊNCIA E DESEMPENHO}

Também é considerada estatisticamente significante a correlação entre competência e desempenho, cujos resultados mostram que a média do grupo RC está no nível 2 (atende plenamente ao esperado para o cargo) em relação tanto à competência quanto ao desempenho. Grupo com alto grau de competência $60 \%$ no nível 2 e apenas $10 \%$ estão abaixo do nível exigido pela empresa.

Tabela 98: Distribuição da correlação entre competência e desempenho no grupo RC (em \%)

\begin{tabular}{|l|r|r|r|r|}
\hline Competência x Desempenho & $0(\mathrm{NA})$ & $1(\mathrm{ED})$ & $2(\mathrm{~A})$ & $3(\mathrm{~S})$ \\
\hline $0(\mathrm{NA})$ & & & & \\
\hline $1(\mathrm{ED})$ & & 10 & 25 & \\
\hline $2(\mathrm{~A})$ & & & 35 & 30 \\
\hline $3(\mathrm{~S})$ & & & & \\
\hline$\%$ & 0 & 10 & 60 & 30 \\
\hline
\end{tabular}




\section{3- MATRIZ DE INTERCORRELAÇÃO - AMOSTRA TOTAL}

Foi realizada uma matriz de intercorrelação geral, que contém 91 intercorrelações, feitas com base no cruzamento de todas as variáveis pesquisadas na amostra total e correlacionadas entre si, conforme o demonstrado no anexo 11.

A seguir apresentamos, na tabela 99, a matriz de intercorrelação da amostra total, com as 23 intercorrelações estatisticamente significantes para os dois grupos.

Tabela 99: Matriz de intercorrelação da amostra total

\begin{tabular}{|c|c|c|c|c|c|c|c|c|c|c|c|}
\hline $\begin{array}{c}\text { Matriz de } \\
\text { intercorrelação } \\
\text { AT }\end{array}$ & Idade & $\begin{array}{c}E . \\
\text { civil }\end{array}$ & $\begin{array}{l}\text { № } \\
\text { filhos }\end{array}$ & $\begin{array}{c}\text { Tpo } \\
\text { empresa }\end{array}$ & $\begin{array}{c}\text { Tpo } \\
\text { profissao }\end{array}$ & \begin{tabular}{|c} 
№ \\
horas
\end{tabular} & $\begin{array}{l}\text { Frequ. } \\
\text { sint. } \\
\text { stress }\end{array}$ & $\begin{array}{l}\text { Intens. } \\
\text { sint. } \\
\text { stress }\end{array}$ & Desempenho & $\begin{array}{l}\text { Total } \\
- \\
\text { NBTA }\end{array}$ & Cluster \\
\hline Sexo & $\begin{array}{l}\mathrm{t}= \\
4,115 \\
\mathrm{p}= \\
0,000\end{array}$ & & $\begin{array}{l}\mathrm{t}= \\
2,744 \\
\mathrm{p}= \\
0,011\end{array}$ & & $\begin{array}{l}t=3,556 \\
p=0,001\end{array}$ & & & $\begin{array}{l}t=- \\
2,668 \\
p= \\
0,011\end{array}$ & $\begin{array}{l}t=2,646 \\
p=0,012\end{array}$ & & \\
\hline Idade & & $\begin{array}{l}t=- \\
2,174 \\
p= \\
0,036\end{array}$ & $\begin{array}{l}r= \\
0,685 \\
p= \\
0,000\end{array}$ & $\begin{array}{l}r=0,653 \\
p= \\
0,000\end{array}$ & $\begin{array}{l}r=0,916 \\
p=0,000\end{array}$ & & & & & & \\
\hline Estado civil & & & $\begin{array}{l}t=- \\
t, 576 \\
p= \\
0,000\end{array}$ & & & & & & & & \\
\hline № filhos & & & & $\begin{array}{l}r=0,595 \\
p= \\
0,000\end{array}$ & $\begin{array}{l}r=0,633 \\
p=0,000\end{array}$ & & & & $\begin{array}{l}r=0,332 \\
p=0,037\end{array}$ & & \\
\hline Escolaridade & & & & $\begin{array}{l}t=2,152 \\
p= \\
0,045\end{array}$ & & & & & & & \\
\hline $\begin{array}{l}\text { Tempo de } \\
\text { empresa }\end{array}$ & & & & & $\begin{array}{l}r=0,648 \\
p=0,000\end{array}$ & $\begin{array}{l}r=- \\
0,341 \\
p= \\
0,034\end{array}$ & & & & $\begin{array}{l}r= \\
0,331 \\
p= \\
0,037 \\
\end{array}$ & \\
\hline $\begin{array}{l}\text { Tempo de } \\
\text { profissão }\end{array}$ & & & & & & & & & $\begin{array}{l}r=0,386 \\
p=0,014\end{array}$ & & \\
\hline $\begin{array}{l}\text { Presença } \\
\text { sintomas } \\
\text { stress }\end{array}$ & & & & & & & $\begin{array}{l}r= \\
0,534 \\
p= \\
0,000\end{array}$ & $\begin{array}{l}r= \\
0,408 \\
p= \\
0,009\end{array}$ & & $\begin{array}{l}r= \\
0,413 \\
p= \\
0,008\end{array}$ & $\begin{array}{l}F= \\
25,584 \\
p=0,000\end{array}$ \\
\hline $\begin{array}{l}\text { Freqüência } \\
\text { sintomas } \\
\text { stress }\end{array}$ & & & & & & & & $\begin{array}{l}r= \\
0,675 \\
p= \\
0,009\end{array}$ & & & $\begin{array}{l}F= \\
15,423 \\
p=0,000\end{array}$ \\
\hline $\begin{array}{l}\text { Intensidade } \\
\text { sintomas } \\
\text { stress }\end{array}$ & & & & & & & & & & & $\begin{array}{l}F= \\
21,632 \\
p=0,000\end{array}$ \\
\hline Competência & & & & & & & & & $\begin{array}{l}r=0,755 \\
p=0,000\end{array}$ & & \\
\hline Total - NBTA & & & & & & & & & & & $\begin{array}{l}F= \\
5,633 \\
p=0,007\end{array}$ \\
\hline
\end{tabular}


Observam-se na matriz acima as seguintes intercorrelações estatisticamente significantes para a amostra total.

\section{SEXO E IDADE}

Verifica-se na amostra total que os homens são a maioria (72,5\%) e apresentam maior média de idade (41,7 anos) do que as mulheres (31,81 anos). A diferença apresentada com relação às mulheres $(27,5 \%)$ estabelece uma correlação estatisticamente significante. As mulheres são em menor número e mais jovens.

Tabela 100: Correlação entre sexo e idade na AT

\begin{tabular}{|c|c|c|}
\hline Sexo $x$ Idade & $\begin{array}{c}\text { Masculino } \\
\%\end{array}$ & $\begin{array}{c}\text { Feminino } \\
\%\end{array}$ \\
\hline $20-30$ & 15 & 12,5 \\
\hline $31-40$ & 22,5 & 15 \\
\hline $41-50$ & 25 & 0 \\
\hline $51-60$ & 10 & 0 \\
\hline$\%$ & 72,5 & 27,5 \\
\hline
\end{tabular}

\section{SEXO E NÚMERO DE FILHOS}

É considerada estatisticamente significante a diferença verificada na amostra total entre o grupo de homens, que apresenta média de 1,31 filhos, e o de mulheres, que têm 0,54 filho.

Tabela 101: Distribuição da correlação entre sexo e n. filhos na AT

\begin{tabular}{|c|c|c|c|c|}
\hline \multirow{2}{*}{$\begin{array}{c}\text { Sexo x N. } \\
\text { Filhos }\end{array}$} & \multicolumn{4}{|c|}{ Grupo R - Número de filhos } \\
\cline { 2 - 5 } & Nenhum & 1 & 2 & 3 \\
\hline Masculino & 22,5 & 10 & 35,0 & 5 \\
\hline Feminino & 15,0 & 10 & 2,5 & 0 \\
\hline$\%$ & 37,5 & 20 & 37,5 & 5 \\
\hline
\end{tabular}

\section{SEXO E TEMPO DE PROFISSÃO}

O grupo de homens apresenta média de 19,27 anos de profissão, enquanto as mulheres têm 10,54 anos. Essa diferença é considerada estatisticamente significante.

Tabela 102: Correlação entre sexo e tempo de profissão na AT (em \%)

\begin{tabular}{|l|r|r|r|r|}
\hline $\begin{array}{c}\text { Sexo x Tempo de } \\
\text { Profissão (anos) }\end{array}$ & $\mathbf{3 - 1 0}$ & $\mathbf{1 1 - 2 0}$ & $\mathbf{2 1}-\mathbf{3 0}$ & $\mathbf{3 1}-\mathbf{4 0}$ \\
\hline Masculino & 22,5 & 22,5 & 20 & 7,5 \\
\hline Feminino & 15,0 & 12,5 & & \\
\hline$\%$ & 37,5 & 35,0 & 20 & 7,5 \\
\hline
\end{tabular}




\section{SEXO E INTENSIDADE DE SINTOMAS DE STRESS}

A intensidade dos sintomas de stress se apresenta em maior nível no grupo das mulheres, média de 4,13 (nível 3, médio alto); no grupo dos homens, a média é de 2,84 (nível 2, médio).

Tabela 103: Correlação entre sexo e intensidade de sintomas de stress na AT (em \%)

\begin{tabular}{|c|c|c|c|c|}
\hline $\begin{array}{c}\text { Sexo x Intensidade } \\
\text { de Sintomas de } \\
\text { Stress }\end{array}$ & Baixo (1) & $\begin{array}{c}\text { Médio } \\
(2)\end{array}$ & $\begin{array}{c}\text { Médio- } \\
\text { Alto (3) }\end{array}$ & Alto (4) \\
\hline Masculino & 7,5 & 45 & 17,5 & 2,5 \\
\hline Feminino & 0 & 10 & 12,5 & 5,0 \\
\hline$\%$ & 7,5 & 55 & 30 & 7,5 \\
\hline
\end{tabular}

\section{SEXO E DESEMPENHO}

Observa-se na tabela 78 abaixo, ao se avaliar a amostra total, que há diferença entre os grupos masculino e feminino quanto ao desempenho, assim como foi verificado no grupo $\mathrm{R}$ separadamente, na análise anterior. Os homens apresentam melhores resultados de desempenho, tendo 22,5\% dos homens atingido nível 3 (superam o desempenho do cargo) .

Tabela 104: Distribuição dos sujeitos conforme a correlação entre sexo e nível de desempenho

\begin{tabular}{|r|r|r|r|r|r|}
\hline $\begin{array}{l}\text { Sexo x } \\
\text { Desempenho }\end{array}$ & 0 (NA) & 1 (ED) & 2 (A) & 3 (S) & \multicolumn{2}{l|}{} \\
\hline $\mathrm{M}$ & 0 & 5,0 & 45 & 22,5 & 72,5 \\
\hline $\mathrm{F}$ & 0 & 2,5 & 25 & 0 & 27,5 \\
\hline
\end{tabular}

\section{IDADE E ESTADO CIVIL}

Verifica-se que, na amostra total, há mais sujeitos no grupo de casados/vivem maritalmente (80\%) do que no grupo de solteiros/separados (20\%).

Tabela 105. Distribuição da correlação entre idade e estado civil na AT

\begin{tabular}{|c|c|c|}
\hline Idade $x$ Estado civil & $\begin{array}{l}\text { Casado+vive } \\
\text { maritalmente }\end{array}$ & Solteiro+separado \\
\hline $20-30$ anos & 17,5 & 10,0 \\
\hline $31-40$ anos & 27,5 & 7,5 \\
\hline $41-50$ anos & 22,5 & 2,5 \\
\hline $51-60$ anos & 12,5 & 0 \\
\hline$\%$ & 80 & 20 \\
\hline
\end{tabular}




\section{IDADE E NÚMERO DE FILHOS}

A correlação verificada entre a idade e o número de filhos é considerada estatisticamente significante, conforme demonstra a tabela 80. A média de filhos da AT é de 1,1 (0,8 para R e 1,4 para RC), e constata-se que 37,5\% não têm filhos. Também se verifica que, desse número, 35\% são sujeitos na faixa etária de 20 a 40 anos.

Tabela 106: Distribuição da correlação entre idade e número de filhos na AT

\begin{tabular}{|l|r|r|r|r|r|}
\hline Idade $\mathbf{x ~ N}$. filhos & $\mathbf{0}$ & $\mathbf{1}$ & $\mathbf{2}$ & $\mathbf{3}$ & Total \\
\hline $\mathbf{2 0}-\mathbf{3 0}$ anos & 20 & $\mathbf{5}$ & 2,5 & 0 & 27,5 \\
\hline $\mathbf{3 1 - 4 0}$ anos & 15 & 10 & 10 & 0 & 35 \\
\hline $\mathbf{4 1 - 5 0}$ anos & 2,5 & 2,5 & 15 & 5 & 25 \\
\hline $\mathbf{5 1 - 6 0}$ anos & 0 & 2,5 & 10 & 0 & 12,5 \\
\hline$\%$ & 37,5 & 20 & 37,5 & 5 & 100 \\
\hline
\end{tabular}

\section{IDADE E TEMPO DE EMPRESA}

A média de idade da AT é de 38,6 anos e a média de tempo na empresa atual é de 9,5 anos. Verifica-se que é uma amostra com sujeitos com bom nível de maturidade e adequado tempo de empresa, embora no grupo $\mathrm{R}$ haja mais jovens (média 36,50) e com menor tempo de empresa (média 6,10) do que no grupo RC (médias 40,70 e 13,00, respectivamente).

Tabela 107: Correlação entre idade e tempo de empresa na AT (em \%)

\begin{tabular}{|l|r|r|r|r|r|}
\hline $\begin{array}{c}\text { Idade } \mathbf{x} \text { Tempo de } \\
\text { Empresa (anos) }\end{array}$ & \multicolumn{1}{|c|}{$\mathbf{- 5}$} & $\mathbf{6 - 1 0}$ & $\mathbf{1 1 - 2 0}$ & $\mathbf{2 1 - 3 0}$ & $\mathbf{3 1 - 4 0}$ \\
\hline $20-30$ anos & 25 & 2,5 & & & \\
\hline $31-40$ anos & 15 & 17,5 & 2,5 & & \\
\hline $41-50$ anos & 5 & 5 & 2,5 & 10 & 2,5 \\
\hline $51-60$ anos & 0 & 5 & 2,5 & & 5,0 \\
\hline$\%$ & 45 & 30 & 7,5 & 10 & 7,5 \\
\hline
\end{tabular}

\section{IDADE E TEMPO DE PROFISSÃO}

Como dito no item anterior, a média de idade da amostra total é de 38,6 anos, já a média de tempo de profissão é de 16,9 anos, o que indica ser uma amostra de sujeitos com elevada experiência/ vivência na profissão, tanto na função de repórter quanto na de repórter cinematográfico. 
Tabela 108: Correlação entre idade e tempo de profissão na AT (em \%)

\begin{tabular}{|l|r|r|r|r|}
\hline $\begin{array}{c}\text { Idade x Tempo de } \\
\text { Profissão (anos) }\end{array}$ & $\mathbf{3 - 1 0}$ & $\mathbf{1 1 - 2 0}$ & $\mathbf{2 1 - 3 0}$ & $\mathbf{3 1 - 4 0}$ \\
\hline $20-30$ anos & 27,5 & & & \\
\hline $31-40$ anos & 7,5 & 25,0 & & \\
\hline $41-50$ anos & & 7,5 & 17,5 & 2,5 \\
\hline $51-60$ anos & & 2,5 & 2,5 & 7,5 \\
\hline$\%$ & 35 & 35 & 20 & 10 \\
\hline
\end{tabular}

\section{ESTADO CIVIL E NÚMERO DE FILHOS}

A correlação estabelecida para a amostra total indica que a maioria dos sujeitos são casados ou vivem maritalmente ( $80 \%$ ) e têm baixo número de filhos (média 1,1)

Tabela 109: Distribuição da correlação entre estado civil e número de filhos na AT (em \%)

\begin{tabular}{|l|c|c|c|c|}
\hline \multirow{2}{*}{ Estado civil } & \multicolumn{4}{|c|}{ Grupo R - Número de filhos } \\
\cline { 2 - 5 } & Nenhum & 1 & 2 & 3 \\
\hline $\begin{array}{l}\text { Solteiros }+ \\
\text { separados }\end{array}$ & 20 & 0 & 0 & 0 \\
\hline $\begin{array}{l}\text { Casados }+ \\
\text { vivem } \\
\text { maritalmente }\end{array}$ & 17,5 & 20 & 37,5 & 5 \\
\hline$\%$ & 37,5 & 20 & 37,5 & 5 \\
\hline
\end{tabular}

\section{NÚMERO DE FILHOS E TEMPO DE EMPRESA}

A amostra total pesquisada apresenta sujeitos com baixo número de filhos (média 1,1) e adequado tempo de empresa (média 9,5 anos).

Tabela 110: Distribuição da correlação entre número de filhos e tempo de empresa na AT (em \%)

\begin{tabular}{|l|c|c|c|c|}
\hline \multirow{2}{*}{$\begin{array}{c}\text { Tempo de } \\
\text { Empresa }\end{array}$} & \multicolumn{4}{|c|}{ Grupo R - Número de filhos } \\
\cline { 2 - 5 } & Nenhum & 1 & 2 & 3 \\
\hline$<1-5$ anos & 27,5 & 7,5 & 10 & \\
\hline $6-10$ anos & 15,0 & 5,0 & 10 & \\
\hline $11-20$ anos & 2,5 & 0 & 5 & \\
\hline $21-30$ anos & 0 & 0 & 5 & 5 \\
\hline $31-40$ anos & 0 & 0 & 7,5 & \\
\hline$\%$ & 45 & 12,5 & 37,5 & 5 \\
\hline
\end{tabular}

\section{NÚMERO DE FILHOS E TEMPO DE PROFISSÃO}

Como visto no item anterior, a amostra total revela sujeitos com baixo número de filhos (média de 1,1) e elevada experiência na profissão (média 16,9 anos), nas duas profissões pesquisadas. 
Tabela 111: Distribuição da correlação entre número de filhos e tempo de profissão na AT (em \%)

\begin{tabular}{|l|c|c|c|c|}
\hline \multirow{2}{*}{$\begin{array}{c}\text { Tempo de } \\
\text { profissão }\end{array}$} & \multicolumn{4}{|c|}{ Grupo R - Número de filhos } \\
\cline { 2 - 5 } & Nenhum & 1 & 2 & 3 \\
\hline $3-10$ anos & 27,5 & 5 & 2,5 & 0 \\
\hline $11-20$ anos & 10,0 & 10 & 15 & 0 \\
\hline $21-30$ anos & 2,5 & 2,5 & 10 & 5 \\
\hline $31-40$ anos & 0 & 0 & 10 & 0 \\
\hline$\%$ & 40 & 17,5 & 37,5 & 5 \\
\hline
\end{tabular}

\section{NÚMERO DE FILHOS E DESEMPENHO}

Conforme observado na tabela abaixo, é considerada estatisticamente significante a correlação verificada entre o número de filhos e o desempenho profissional. Constata-se que é uma amostra de sujeitos com baixo número de filhos (média 1,1) e que apresenta uma média de desempenho no nível 2 (média 2,2), que atende plenamente ao padrão esperado pela empresa.

Tabela 112: Distribuição da correlação entre número de filhos e desempenho na AT (em \%)

\begin{tabular}{|c|c|c|c|c|}
\hline N. Filhos $x$ Desempenho & O(NA) & $1(\mathrm{ED})$ & $2(\mathrm{~A})$ & $3(\mathrm{~S})$ \\
\hline Nenhum & & 2,5 & 32,5 & 2,5 \\
\hline 1 & & 0 & 17,5 & 5,0 \\
\hline 2 & & 2,5 & 20 & 12,5 \\
\hline 3 & & 2,5 & 0 & 2,5 \\
\hline$\%$ & & 7,5 & 70 & 22,5 \\
\hline
\end{tabular}

\section{ESCOLARIDADE E TEMPO DE EMPRESA}

Da amostra total de sujeitos, $65 \%$ têm como nível de escolaridade o curso superior completo ou pós-graduação e tempo médio de 9,5 anos na empresa atual. Verifica-se que é uma amostra que pode evoluir no aspecto da escolaridade e um grupo com estabilidade adequada na empresa em que trabalha atualmente.

Tabela 113: Distribuição da correlação entre escolaridade e tempo de empresa na AT (em \%)

\begin{tabular}{|l|r|l|l|l|l|}
\hline $\begin{array}{c}\text { Escolaridade } x \\
\text { Tempo de } \\
\text { Empresa }\end{array}$ & $\begin{array}{l}<1-5 \\
\text { anos }\end{array}$ & $\begin{array}{l}6-10 \\
\text { anos }\end{array}$ & $\begin{array}{l}11-20 \\
\text { anos }\end{array}$ & $\begin{array}{l}21-30 \\
\text { anos }\end{array}$ & $\begin{array}{l}\text { ln } \\
\text { anos }\end{array}$ \\
\hline $\begin{array}{l}2^{\circ} \text { grau + superior } \\
\text { incompleto }\end{array}$ & 10 & 7,5 & 5 & 7,5 & 5 \\
\hline $\begin{array}{l}\text { Superior + pós- } \\
\text { graduação }\end{array}$ & 35 & 22,5 & 2,5 & 2,5 & 2,5 \\
\hline$\%$ & 45 & 30 & 7,5 & 10 & 7,5 \\
\hline
\end{tabular}




\section{TEMPO DE EMPRESA E TEMPO DE PROFISSÃO}

Verifica-se na amostra total a média de 9,5 anos de tempo na atual empresa, bem como a média de 16,9 anos de tempo de profissão. Ambas as médias são consideradas elevadas e expressivas para essas profissões.

Tabela 114: Distribuição da correlação entre tempo de empresa e tempo de profissão na AT (em \%)

\begin{tabular}{|l|r|r|r|r|}
\hline $\begin{array}{l}\text { Tempo de empresa x Tempo de } \\
\text { Profissão }\end{array}$ & $\begin{array}{r}3-10 \\
\text { anos }\end{array}$ & $\begin{array}{r}11-20 \\
\text { anos }\end{array}$ & $\begin{array}{r}21-30 \\
\text { anos }\end{array}$ & $\begin{array}{r}31-40 \\
\text { anos }\end{array}$ \\
\hline$<1-5$ anos & 27,5 & 2,5 & 2,5 & 0 \\
\hline $6-10$ anos & 7,5 & 12,5 & 2,5 & 2,5 \\
\hline $11-20$ anos & 12,5 & 2,5 & 10 & 0 \\
\hline $21-30$ anos & 5 & 0 & 5 & 0 \\
\hline $31-40$ anos & 0 & 0 & 0 & 7,5 \\
\hline$\%$ & 52,5 & 17,5 & 20 & 10 \\
\hline
\end{tabular}

\section{TEMPO DE EMPRESA E NÚMERO DE HORAS TRABALHADAS}

A amostra total revela a média de 9,5 anos de tempo na empresa atual e a média de 8,2 horas trabalhadas/dia, o que é compatível com o padrão adequado de jornada de trabalho na empresa. Verifica-se, no entanto, que o grupo R tem uma média mais elevada de horas trabalhadas $(8,80)$ do que o grupo RC $(7,58)$.

Tabela 115: Correlação entre tempo de empresa e N. hs /dia na AT (em \%)

\begin{tabular}{|l|r|r|r|r|}
\hline Tempo de empresa $\mathbf{x}$ N. horas/dia & $7-8$ & 9 & 10 & $>10$ \\
\hline$<1-5$ anos & 25 & 12,5 & 7,5 & \\
\hline $6-10$ anos & 12,5 & 7,5 & 5 & 2,5 \\
\hline $11-20$ anos & 5 & 0 & 5 & \\
\hline $21-30$ anos & 10 & 0 & 0 & \\
\hline $31-40$ anos & 7,5 & 0 & 0 & \\
\hline$\%$ & 60 & 20 & 17,5 & 2,5 \\
\hline
\end{tabular}

\section{TEMPO DE EMPRESA E COMPORTAMENTO TIPO A}

A amostra total evidencia que os sujeitos, além de apresentarem elevado tempo na empresa atual (média de 9,5 anos), apresentam alto nível de comportamento tipo A (média 70,95). 
Tabela 116: Correlação entre tempo de empresa e comportamento tipo A na AT (em \%)

\begin{tabular}{|l|r|r|r|r|r|}
\hline $\begin{array}{l}\text { Tempo de empresa x } \\
\text { Comportamento Tipo A }\end{array}$ & Baixo & $\begin{array}{l}\text { Baixo- } \\
\text { Médio }\end{array}$ & \multicolumn{1}{c|}{ Médio } & \multicolumn{1}{c|}{ Alto } & Altíssimo \\
\hline$<1-5$ anos & & 2,5 & 15 & 20 & 7,5 \\
\hline $6-10$ anos & & & 5 & 17,5 & 7,5 \\
\hline $11-20$ anos & & & & 7,5 & \\
\hline $21-30$ anos & & & & 7,5 & 2,5 \\
\hline $31-40$ anos & & & & 5 & 2,5 \\
\hline$\%$ & 0 & 2,5 & 20 & 57,5 & 20 \\
\hline
\end{tabular}

\section{TEMPO DE PROFISSÃO E DESEMPENHO}

Verifica-se que os sujeitos, além de apresentarem elevada média de tempo de profissão (16,9 anos), revelam adequado nível de desempenho (média 2,2), o que atende ao padrão definido pela empresa (nível 2).

Tabela 117: Distribuição da correlação entre tempo de profissão e desempenho na AT (em \%)

\begin{tabular}{|l|r|r|r|r|}
\hline Tempo de profissão x Desempenho & O(NA) & $1(\mathrm{ED})$ & $2(\mathrm{~A})$ & $3(\mathrm{~S})$ \\
\hline$<1-10$ anos & & 2,5 & 30 & 2,5 \\
\hline $11-20$ anos & & 2,5 & 25 & 7,5 \\
\hline $21-30$ anos & & 2,5 & 12,5 & 5 \\
\hline $31-40$ anos & & 0 & 2,5 & 7,5 \\
\hline$\%$ & & 7,5 & 70 & 22,5 \\
\hline
\end{tabular}

\section{PRESENÇA E FREQÜÊNCIA DE SINTOMAS DE STRESS}

A média da freqüência de sintomas de stress demonstrada está no nível 2 - médio $(1,28)$, porém a presença desses sintomas é de 62\%, sendo considerada um nível alto de stress (nível 4).

Tabela 118: Correlação entre presença e frequiência de sintomas de stress na AT (em \%)

\begin{tabular}{|l|r|r|r|r|}
\hline $\begin{array}{l}\text { Presença x Freqüência de } \\
\text { Sintomas de Stress }\end{array}$ & Baixo (1) & Médio (2) & $\begin{array}{c}\text { Médio-Alto } \\
(3)\end{array}$ & Alto (4) \\
\hline Baixo (1) & & & & \\
\hline Médio (2) & 5 & 17,5 & & \\
\hline Médio-Alto (3) & 7,5 & & & \\
\hline Alto (4) & 2,5 & 27,5 & 5 & \\
\hline Altíssimo (5) & 0 & 27,5 & 5 & 2,5 \\
\hline$\%$ & 15 & 72,5 & 10 & 2,5 \\
\hline
\end{tabular}




\section{PRESENÇA E INTENSIDADE DE SINTOMAS DE STRESS}

A amostra total denota nível alto $(62 \%)$ de presença de sintomas de stress (nível 4), todavia o nível de intensidade dos sintomas apresentados é médio (média 3,2 - nível 2).

Tabela 119: Correlação entre presença e intensidade de sintomas de stress na AT (em \%)

\begin{tabular}{|l|r|r|r|r|}
\hline $\begin{array}{l}\text { Presença x Intensidade de } \\
\text { Sintomas de Stress }\end{array}$ & Baixo (1) & Médio (2) & \multicolumn{1}{c|}{$\begin{array}{c}\text { Médio-Alto } \\
\text { (3) }\end{array}$} & Alto (4) \\
\hline Baixo (1) & & & & \\
\hline Médio (2) & 2,5 & 15 & 5 & \\
\hline Médio-Alto (3) & & & & \\
\hline Alto (4) & & 27,5 & 7,5 & 2,5 \\
\hline Altíssimo (5) & 5 & 12,5 & 17,5 & 5 \\
\hline$\%$ & 7,5 & 55 & 30 & 7,5 \\
\hline
\end{tabular}

\section{PRESENÇA DE SINTOMAS DE STRESS E COMPORTAMENTO TIPO A}

O nível de presença de sintomas de stress da amostra total é alto (62\%), bem como os resultados do padrão de comportamento tipo A dos sujeitos pesquisados (média 70,95).

Tabela 120: Correlação entre freqüência de sintomas de stress e comportamento tipo A na AT (em \%)

\begin{tabular}{|l|l|r|r|r|r|}
\hline $\begin{array}{l}\text { Presença de Sintomas de } \\
\text { Stress x Compto Tipo A }\end{array}$ & Baixo & \multicolumn{1}{|c|}{$\begin{array}{l}\text { Baixo- } \\
\text { Médio }\end{array}$} & \multicolumn{1}{|c|}{ Médio } & \multicolumn{1}{c|}{ Alto } & Altíssimo \\
\hline Baixo (1) & & & & & \\
\hline Médio (2) & & 2,5 & 7,5 & 12,5 & \\
\hline Médio-Alto (3) & & & & & \\
\hline Alto (4) & & & 7,5 & 22,5 & 7,5 \\
\hline Altíssimo (5) & & & 5 & 27,5 & 7,5 \\
\hline$\%$ & & 2,5 & 20 & 62,5 & 15 \\
\hline
\end{tabular}

\section{FREQÜENCIA E INTENSIDADE DE SINTOMAS DE STRESS}

Observa-se que tanto a freqüência de sintomas de stress (média 1,28) quanto a intensidade dos sintomas (média 3,2) apresentaram resultados médios (nível 2).

Tabela 121: Correlação entre freqüência e intensidade de sintomas de stress na AT (em \%)

\begin{tabular}{|l|r|r|r|r|}
\hline $\begin{array}{l}\text { Freqüência x Intensidade } \\
\text { de Sintomas de Stress }\end{array}$ & Baixo (1) & \multicolumn{1}{|c|}{ Médio (2) } & \multicolumn{1}{|c|}{$\begin{array}{l}\text { Médio-Alto } \\
\text { (3) }\end{array}$} & Alto (4) \\
\hline Baixo (1) & 2,5 & 10 & 2,5 & \\
\hline Médio (2) & 5 & 40 & 25 & 2,5 \\
\hline Médio-Alto (3) & & 2,5 & 5 & 2,5 \\
\hline Alto (4) & & & & 2,5 \\
\hline$\%$ & 7,5 & 52,5 & 32,5 & 7,5 \\
\hline
\end{tabular}




\section{COMPETÊNCIA E DESEMPENHO}

As médias apresentadas na amostra total indicam que os níveis de competência $(1,8)$ e desempenho $(2,2)$ dos sujeitos atendem plenamente ao padrão de resultado esperado pela empresa para os cargos em questão (nível 2).

Tabela 122: Distribuição da correlação entre competência e desempenho na AT (em \%)

\begin{tabular}{|l|r|r|r|r|}
\hline Competência x Desempenho & $0(\mathrm{NA})$ & 1 (ED) & $2(\mathrm{~A})$ & $3(\mathrm{~S})$ \\
\hline $0(\mathrm{NA})$ & & & & \\
\hline $1(\mathrm{ED})$ & & 7,5 & 17,5 & \\
\hline $2(\mathrm{~A})$ & & & 52,5 & 20 \\
\hline $3(\mathrm{~S})$ & & & & 2,5 \\
\hline$\%$ & & 7,5 & 70 & 22,5 \\
\hline
\end{tabular}




\section{4- FORMAÇÃO DE CLUSTER}

Realizou-se também o agrupamento dos sujeitos da amostra total com resultados semelhantes, levando-se em conta todas as respostas dos testes: NBTA (total e fatores), LSS/VAS (nível de presença, freqüência, intensidade, nível geral e fases de stress), níveis de competência e desempenho. A análise estatística identificou os resultados dos sujeitos nos testes e, ao mesmo tempo, considerou os mais semelhantes entre todos da amostra, reunindo os sujeitos em um grupo só, com mais semelhanças em relação a alguns testes e fatores.

Essa análise resultou na sugestão da formação de três clusters, que, de acordo com os resultados, apresentaram as características comuns abaixo descritas.

\section{CLUSTER PERIGO ALTO}

$\mathrm{O} 1^{\circ}$ cluster é formado pelo agrupamento de 9 sujeitos, com os seguintes resultados comuns:

- Fase de stress no nível 3 (perigo);

- Nível geral de stress no nível 3 (médio alto);

- Presença de sintomas de stress no nível 3 (médio alto);

- Intensidade de sintomas de stress no nível 3 (médio alto).

Trata-se de um subgrupo de telejornalistas da amostra pesquisada que requer muita atenção quanto à questão do stress, na medida em que vários resultados dos testes apontam que os sujeitos estão na fase de perigo e convergem para sintomas de nível médio alto (quanto ao nível geral, presença e intensidade).

\section{CLUSTER PERIGO MÉDIO}

O $2^{\circ}$ cluster resulta do agrupamento de 19 sujeitos, com as seguintes variáveis comuns entre si:

- Fase de stress no nível 2 (alarme);

- Nível geral de stress no nível 2 (médio);

- Presença de sintomas de stress no nível 2 (médio);

- Padrão de comportamento tipo A - fator nervosismo (baixo médio). 
Esse agrupamento de mais sujeitos do que no subgrupo anterior apresenta características da fase de alarme com relação ao stress, sintomas no nível médio e comportamento tipo A no nível baixo médio, correspondente ao fator nervosismo.

\section{CLUSTER LEVE}

O $3^{\circ}$ cluster é representado pelo agrupamento de 12 sujeitos com as seguintes características comuns:

- Fase de stress no nível 1 (leve);

- Nível geral de stress no nível 1 (leve);

- Presença de sintomas de stress no nível 1 (baixo);

- Frequiência de sintomas de stress no nível 1 (baixo);

- Padrão de comportamento tipo A - fator nervosismo (baixo).

Esse agrupamento revela sujeitos com menor nível de stress, bem como baixo padrão de comportamento tipo A, correspondente ao fator nervosismo.

Apesar das variáveis desempenho e competência terem sido incluídas na formação dos clusters, elas não foram consideradas importantes para a constituição dos mesmos.

A figura 32 ilustra a distribuição dos três clusters, sob a forma de "nuvem de pontos".

O cluster 1 (Perigo Alto) é o agrupamento de cor vermelho, o cluster 2 (Perigo Médio) em azul (verifica-se que dois sujeitos são totalmente iguais quanto aos resultados, e portanto dois pontos estão sobrepostos) e o cluster 3 (Perigo Leve) em verde. 


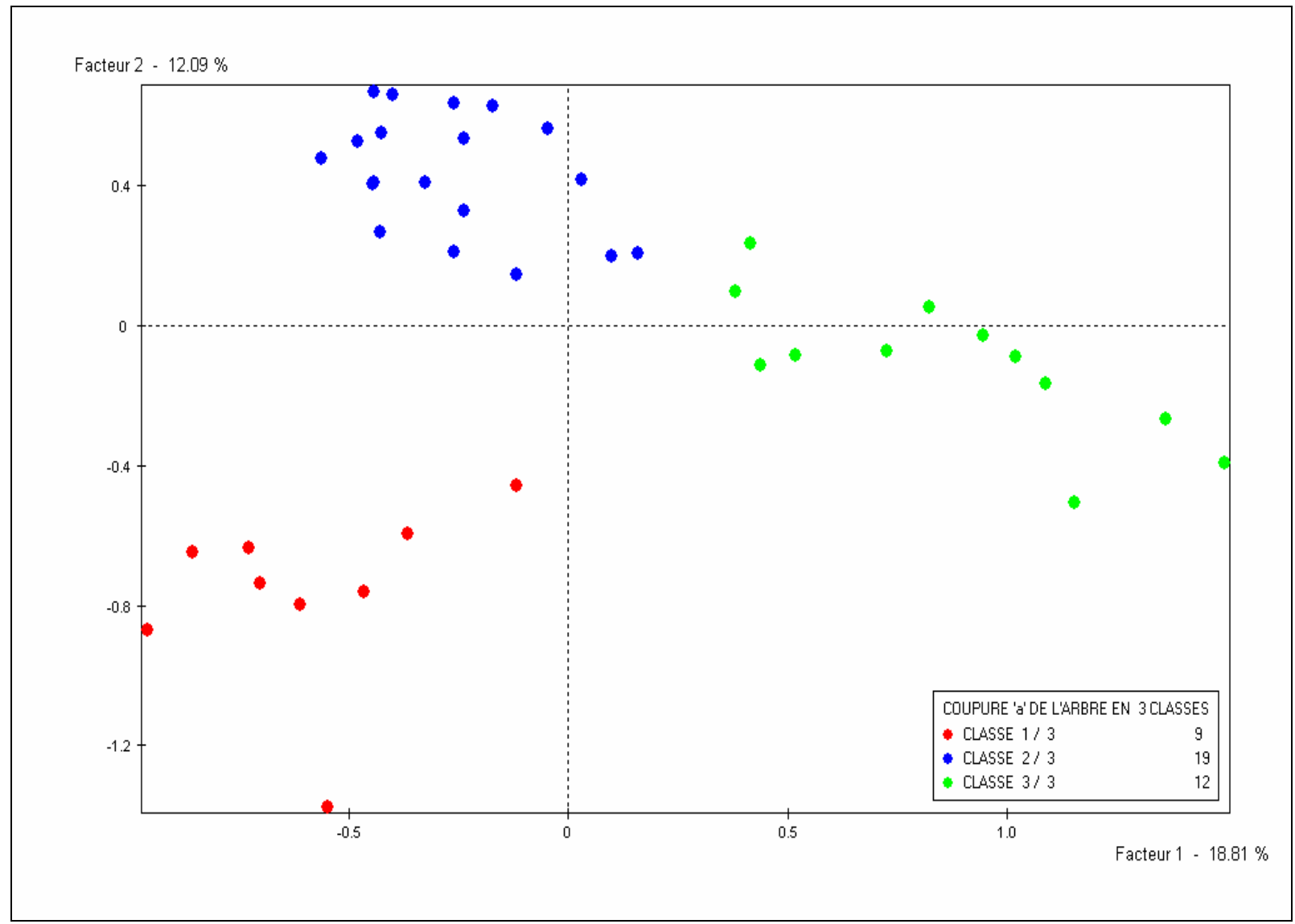

Figura 32. Distribuição dos sujeitos em clusters, considerando a Amostra Total. 


\section{DISCUSSÃO}




\section{DISCUSSÃO DOS RESULTADOS}

O presente estudo possibilitou pesquisar o nível de stress em profissionais de telejornalismo, bem como estabelecer correlações com o nível de desempenho profissional. Também foram estabelecidas correlações do nível de stress com o nível de competência e com o padrão de comportamento tipo $\mathrm{A}$, a serem discutidas a seguir. Correlações entre outras variáveis da pesquisa, consideradas relevantes, complementaram este estudo.

Nessa discussão comentaremos apenas os dados que são significantes para caracterizar a amostra. Todos os demais já foram apontados no capítulo relativo aos resultados.

\section{PARTE 1 - CARACTERIZAÇÃO DA AMOSTRA}

\section{SEXO}

O jornalismo era uma profissão predominantemente masculina no Brasil antes dos anos 50, pela natureza da própria tarefa, que demandava horas de trabalho em demasia dentro e fora da redação para buscar a notícia e, conseqüentemente ausência do lar e do convívio com os filhos. A partir dos anos 60, os avanços tecnológicos, as acentuadas mudanças sociais, a entrada da mulher no mercado, bem como o crescimento das agências de notícias que disseminam informações para todas as redações e as formas mais eficazes de organização do trabalho nas empresas de telejornalismo facilitaram a adaptação das mulheres à função de repórter.

A presença do gênero feminino cresceu nas redações e hoje é possível compatibilizar o trabalho com a vida pessoal, por isso a função de repórter passou a ser desejada e vista como desafio e oportunidade de realização profissional. Essa característica se evidencia na amostra pesquisada, em que o número de mulheres é equilibrado em relação ao de homens na função de repórter. No entanto, com relação aos repórteres cinematográficos, essa mudança aparece de forma pouco consistente, revelando ser ainda uma função de predomínio masculino. A melhoria das condições ergonômicas dos equipamentos, como a leveza das câmeras digitais, poderá favorecer também o aumento da ocupação dessas vagas de trabalho pelas mulheres. 


\section{NÚMERO DE FILHOS}

A amostra pesquisada revelou diferença significante no número de filhos entre os grupos $\mathrm{R}$ e RC, mostrando que os repórteres têm menos filhos. Pode-se explicar essa diferença pelo fato de os repórteres pesquisados terem, em média, menos idade do que os repórteres cinematográficos. Além disso, há a tendência no mundo contemporâneo de pessoas com maior grau de escolaridade e melhor renda fazerem opção por maior controle de natalidade.

\section{GRAU DE ESCOLARIDADE}

As características da profissão de repórter requerem grau de escolaridade diferenciado e habilidades como o domínio da língua portuguesa, a capacidade de análise e a rápida interpretação e síntese dos acontecimentos relatados. A amostra pesquisada revelou que todos os repórteres têm grau superior de escolaridade, mas não ocorre o mesmo com o grupo de repórteres cinematográficos. A natureza do trabalho dos repórteres cinematográficos requer capacitação voltada para os aspectos de sensibilidade artística e técnica preponderantemente, enquanto a capacitação dos repórteres depende de adequado grau de atualização intelectual e especialização em assuntos vinculados às reportagens.

No entanto a necessidade de alto padrão de escolaridade tem relação com a exigência atual da empresa de elevar o nível cultural e de atualização do repórter cinematográfico, pois essa função hoje demanda uma atuação autônoma e pró-ativa, voltada para a captação de imagens de conteúdo jornalístico, inéditas e ousadas, diferentemente do cinegrafista do passado, que apenas atuava como apoio ao repórter.

\section{TEMPO NA EMPRESA ATUAL}

Em telejornalismo, a função do repórter é tão estratégica quanto a do repórter cinematográfico, pois ambas assumem papéis vitais para o veículo e para o contexto democrático, em que a perspicácia e a astúcia dos profissionais no seu trabalho levam a reportar diariamente acontecimentos que mudam a vida da sociedade. Uma característica a destacar nos resultados é que os repórteres têm, em média, pouco tempo na empresa atual (6,1 anos), porém revelam ser qualificados e experientes na profissão. Muitos dos selecionados vêm de outros veículos de comunicação e têm grande valor para a empresa. Verifica-se que os repórteres com mais tempo de empresa são direcionados para atividades "especiais" e menos para atividades 
"diaristas", que ficam para os repórteres mais jovens. Nesse sentido a função é mais versátil, pois permite movimentação interna, maior do que a observada na categoria de repórter cinematográfico.

\section{NÚMERO DE HORAS DE TRABALHO/DIA}

A diferença das médias de horas de trabalho/dia dos grupos $\mathrm{R}$ e $\mathrm{RC}$ indica que os repórteres trabalham mais horas do que os repórteres cinematográficos. De maneira geral, verifica-se que a acentuada interferência da tecnologia, como o uso de ilhas de edição nãolineares, equipamentos digitais e computador associado à internet, tem contribuído para a redução do número de horas de trabalho na redação, tanto na jornada dos repórteres quanto na dos repórteres cinematográficos.

Pode-se observar que o fato de os repórteres, ao chegarem da rua, participarem da finalização das matérias juntamente com os editores de texto e de imagem pode levá-los a estender a carga de trabalho, mais do que ocorre com os repórteres cinematográficos. O uso da tecnologia facilita o desenvolvimento do trabalho técnico, porém não exclui a necessidade do contato do repórter no fechamento da matéria. 


\section{PARTE 2 - RESULTADOS DOS INSTRUMENTOS}

\section{PADRÃO DE COMPORTAMENTO TIPO A - FATOR "URGÊNCIA DE TEMPO"}

$\mathrm{Na}$ análise dos resultados dos instrumentos, verifica-se que a variável "urgência de tempo" apresentou correlação significante com o padrão de comportamento tipo A nos dois grupos, com média superior no grupo de repórteres. Podemos inferir que essa característica está mais impregnada no comportamento do repórter, pois tem relação com a natureza das tarefas habituais que desenvolve, ou seja, ele é pressionado pelo tempo de preparar a matéria e transmitir a notícia com precisão e esse fato está mais presente nesse grupo do que na atividade do repórter cinematográfico, que não exige investigação de dados.

\section{INTENSIDADE DE SINTOMAS DE STRESS}

Com relação ao stress, a diferença significante só ocorreu no que diz respeito à intensidade dos sintomas nos dois grupos: o grupo $\mathrm{R}$ apresentou nível de intensidade maior de sintomas stress do que o grupo RC. Pode-se explicar essa diferença pelo fato de o repórter estar mais propenso a se envolver afetivamente na situação de reportagem, e essa constatação pode estar relacionada com os sintomas de natureza emocional e cognitiva, que mais se destacaram nesta pesquisa entre os sintomas mais representativos para esse grupo.

De acordo com o perfil de personalidade do repórter, ele pode vivenciar com maior intensidade uma situação stressora, porque a tarefa requer discernimento e comprometimento com a veracidade dos fatos. Já o repórter cinematográfico poderá distanciar-se afetivamente em maior grau, o que gera menor intensidade de sintomas de stress. 


\section{PARTE 3 - CORRELAÇÕES SIGNIFICANTES}

Para finalizar, cruzamos todos os resultados significantes e observamos correlações que isoladamente, na análise de significância, não apareceram. Notamos, por exemplo, que a presença de sintomas de stress não é variável significante para diferenciar os dois grupos, porém na relação com frequiência e intensidade de sintomas ela é. Correlações entre outras variáveis da pesquisa, consideradas relevantes, complementam este estudo.

\section{CORRELAÇÃO ENTRE SEXO E OUTRAS VARIÁVEIS}

Os repórteres e repórteres cinematográficos do sexo feminino da amostra pesquisada são em menor número e mais jovens do que os do sexo masculino. Apesar desse resultado, verificase que as mulheres de modo geral estão cada vez mais ingressando na carreira telejornalística, pelas oportunidades que as empresas oferecem para as duas categorias. Aliado a esse aspecto, pode-se analisar, na amostra investigada, a correlação do sexo com o desempenho, identificandose que os telejornalistas homens, que têm maior tempo de profissão, adquiriram experiência maior, que os capacitou para um desempenho melhor do que o dos profissionais do sexo feminino.

\section{CORRELAÇÃO ENTRE IDADE E OUTRAS VARIÁVEIS}

Para a profissão de repórter e de repórter cinematográfico, a variável "idade" não tem relevância na medida em que não diferencia os dois grupos, porém quando analisada conjuntamente com o tempo de empresa e de profissão, bem como com o nível de competência e desempenho, mostra-se significante nos grupos R e RC e na amostra total.

A experiência, a vivência dos repórteres e repórteres cinematográficos pesquisados é elevada (AT - a média de profissão é de 16,9 anos), bem como o tempo médio na empresa atual (9,5 anos). Esses resultados, aliados ao elevado nível de competência (77,5\% nos nível 2 e 3) e de desempenho (92,5 \% nos níveis 2 e 3), indicam que é uma amostra com perfil adequado e alto grau de adaptação à cultura e valores da empresa, o que favorece o desenvolvimento das funções. Os repórteres cinematográficos têm maior tempo na empresa atual e esse dado pode estar relacionado com as adequadas condições oferecidas pela empresa, bem como com menores oportunidades de colocação no mercado. 


\section{CORRELAÇÃO ENTRE ESTADO CIVIL E OUTRAS VARIÁVEIS}

Os repórteres direcionam seus esforços para o trabalho, deslocam-se geograficamente para fazer matérias e extrapolam a jornada de trabalho diário. De maneira geral, para alguns sujeitos, a família, os compromissos sociais e o lazer ficam em segundo plano e, conseqüentemente, não ter ou ter poucos filhos facilita atender as exigências do trabalho. É bastante comum encontrar, na redação, repórteres e repórteres cinematográficos casados com outros telejornalistas, também colegas de trabalho.

\section{CORRELAÇÃO ENTRE NÚMERO DE FILHOS E OUTRAS VARIÁVEIS}

Nos grupos R e RC e na AT, a correlação da variável "número de filhos" com tempo de empresa, tempo de profissão, competência e desempenho parece estar mais relacionada com o fato de os repórteres cinematográficos $(65 \%)$ terem mais filhos do que os repórteres. Esse fator pode ter influenciado a característica da amostra, ou seja, a estabilidade na empresa e na

profissão pode levar as pessoas a planejarem a família com maior número de filhos e a se dedicarem com grande nível de competência e desempenho no trabalho.

\section{CORRELAÇÃO ENTRE ESCOLARIDADE E OUTRAS VARIÁVEIS}

A variável "escolaridade" tem correlação significante com todas as outras variáveis, uma vez que a condição de maior nível cultural e intelectual, como já mencionamos, é fator determinante para a atuação em telejornalismo.

\section{CORRELAÇÃO ENTRE TEMPO DE EMPRESA E TEMPO DE PROFISSÃO E OUTRAS VARIÁVEIS}

Os resultados confirmam que o padrão de comportamento tipo A é compatível com o que a empresa espera da atuação dos telejornalistas, isto é, que estejam adaptados à urgência de tempo, ao padrão de competência, nível de ambição etc. Essas características dos sujeitos pesquisados, aliadas ao tempo de profissão e à vivência na empresa atual, são mais aderentes à cultura organizacional, portanto são fundamentais para o desempenho em ambas as funções, o que pode explicar as correlações significantes. 


\section{CORRELAÇÃO ENTRE NÚMERO DE HORAS E COMPORTAMENTO TIPO A}

O comportamento dos sujeitos relacionados ao padrão tipo A, especialmente no grupo dos repórteres, aponta para uma dedicação maior em termos de número de horas de trabalho/dia do que a dos repórteres cinematográficos, o que pode estar relacionado a uma tendência dos sujeitos a ter dificuldade de desligar-se do trabalho e de sentir auto-sobrecarga.

\section{CORRELAÇÃO ENTRE NÍVEIS DE STRESS E OUTRAS VARIÁVEIS}

\section{A) COM PRESENÇA, FREQÜÊNCIA E INTENSIDADE DE SINTOMAS}

Os resultados evidenciaram que os dois grupos de telejornalistas apresentaram sintomas de stress importantes a considerar. Levando-se em conta os resultados do teste LSS/VAS, obteve-se que tanto os repórteres quanto os repórteres cinematográficos apresentaram alto nível de presença de sintomas de stress, resultados compatíveis com os pesquisados por Coelho (2002). As correlações são várias e significantes entre presença, freqüência e intensidade e entre freqüência e intensidade.

Os sintomas auto-atribuídos corresponderam, na lista de classificação, às doze respostas mais representativas para eles e, como já mencionado, são, em sua maioria, provenientes de situações de natureza emocional ("sinto angústia", "fico esgotado emocionalmente"); em segundo lugar, de natureza cognitiva ("tenho pensamentos que me deixam ansioso"); em terceiro, de natureza social ("tenho vontade de ficar sozinho"); por último, de natureza fisiológica ("tenho cansaço", "meus músculos estão sempre tensos"). Embora também haja sintomas claros de fadiga física nas respostas, verifica-se que os sintomas de natureza emocional ou cognitiva são os que preponderam nos dois grupos e estão relacionados à fase de resistência do stress, ou seja, o stress parece fazer parte do cotidiano das relações dos telejornalistas no trabalho e na vida pessoal.

Quando analisados os resultados sob o ponto de vista do nível geral nos grupos R e RC, não houve resultados significantes, porém temos que considerar que o nível geral de stress é médio alto e o nível de frequiência é médio. Na classificação de nível geral de stress, o nível alto se subdivide em: médio alto, alto e altíssimo. O nível geral de stress (com suas subdivisões) indica que os sujeitos estão na fase de stress de perigo agudo, a qual se localiza imediatamente 
antes da fase de exaustão. Os resultados obtidos revelaram que os grupos não demonstraram diferenças significantes entre si, todavia ressaltamos que os dois grupos apresentam nível de presença de sintomas de stress alto, nível geral de stress médio alto e que há sinais de stress na fase de perigo agudo, que podem ser indicativos de danos à saúde dos sujeitos.

Analisaremos os elevados resultados de stress acima expostos segundo a dimensão biopsicossocial de stress de Lazarus e Folkman (1984; 2000) e de Vasconcelos (2000; 2002) e segundo os estudos sobre ambiente de trabalho de Baker e Karasek (1999), que são referência na área que investiga o stress ocupacional.

A natureza da tarefa telejornalística, diarista ou especial, as demandas da organização (modelo de gestão) e o tipo de padrão de comportamento e personalidade estimulam os sujeitos ao contato permanente com agentes stressores de ordem exógena (estímulos sócio-ambientais), o que implica equilíbrio e desequilíbrio internos constantes, com interferência de fatores endógenos (processos emocionais e da própria cognição dos sujeitos) (VASCONCELLOS, 2000; 2002).

Fatores exógenos - Tomando por base a descrição dos cargos de repórter e de repórter cinematográfico feita no capítulo III, verifica-se que os telejornalistas trabalham com situações ambientais potencialmente estressantes: situações novas e imprevisibilidade do contexto emergente, incertezas ou iminências dos acontecimentos, ambigüidades ou falta de informações completas (LIMONGE E RODRIGUES, 2002).

Considerando os estudos de Baker e Karasek (1999, apud LIMONGE E RODRIGUES, 2002), alguns stressores estão presentes na natureza da tarefa e no ambiente interno da organização (modelo de gestão): exigências de tempo (necessidade de o sujeito fazer horas extras para cumprir demandas por crise ou urgência), estrutura temporal (trabalhos em turnos e plantões, de acordo com os fatos e eventos) e ritmo (agilidade constante para atender ao fechamento dos telejornais), organização do trabalho (entradas ao vivo, contato com conteúdos relacionados a fatos dramáticos, controle e cobrança por resultados, competição por busca de novas pautas de notícias e imagens de interesse, necessidade de reconhecimento profissional, maior retorno do desempenho, preocupação com carreira) e fatores externos à organização (insegurança no trânsito e em locais de maior violência, empregabilidade).

Conforme os autores, há fatores que funcionam como moderadores do stress e que dependem da estrutura e condições de suporte social da empresa, modelo de gestão e forma de 
organização do trabalho. De maneira geral, considerando-se o tipo de empresa onde a presente pesquisa foi realizada, podemos indicar alguns fatores moderadores de stress: gestão e estrutura das tarefas (a gestão é participativa, os sujeitos contribuem e se posicionam sobre o desenvolvimento de seu trabalho, também são reconhecidos pelos resultados da equipe e pelo nível de competência e desempenho individual), condições físicas (há constante cuidado e monitoramento da saúde e ergonomia, investimento em equipamentos novos), organização do trabalho (a estrutura organizacional é clara, com níveis de reporte hierárquico bem definidos, assim como os papéis e responsabilidades, tomadas de decisão dentro do escopo de responsabilidade da função) e fatores externos ao trabalho (adequado suporte social).

Fatores endógenos - Lazarus e Folkman (2000) consideram que o ser humano tem como condição ontológica a busca pelo sentido de adaptação bem-sucedida e que cada pessoa tem uma reação distinta ao stress. Essa variação está diretamente relacionada à maneira como a pessoa interpreta cognitivamente as situações, ao julgamento que faz dos stressores, intermediada pela emoção em relação ao objeto, fruto da sua história pessoal e do significado para o sujeito, e às suas habilidades de coping (capacidade de enfrentamento). Dessa forma, as condições fisiológicas dos sujeitos, em especial o coping, são fatores moderadores do stress.

$\mathrm{Na}$ medida em que a maioria dos telejornalistas da pesquisa tem média elevada de tempo de profissão e adequado desempenho, podemos inferir que a natureza do trabalho jornalístico deve ser algo desafiador e não ameaçador, que gera sensação de dever cumprido, sentimento de orgulho, de desenvolvimento emocional e intelectual, reação própria de adaptação e de eustress. Por ser a atividade de reportagem uma situação rotineira para ambas as funções pesquisadas, provavelmente não é considerada como distressante, na medida em que tem caráter de desafio a ser vencido diariamente. Coelho (2002) considera que a tarefa de falar ao vivo é percebida pelo repórter como mais desafiadora do que o perigo, porque aumenta as catecolaminas e diminui ou mantém o nível de cortisol, porém o estado de desafio não pode ser considerado como irrelevante, pois se for freqüente e intenso pode desencadear doenças.

\section{B) COM RELAÇÃO AO PADRÃO DE COMPORTAMENTO TIPO A}

O comportamento dos repórteres e repórteres cinematográficos, investigados com a aplicação do teste BEPATYA (NBTA), evidenciou características próprias do padrão de comportamento tipo A, necessárias à adaptação às atividades jornalísticas. As correlações 
apontam que os sujeitos da pesquisa têm alto padrão de comportamento tipo A, como também foi verificado por Coelho (2002). A correlação mais significante desse fator no grupo R foi com a freqüência de sintomas e, na amostra total, com a presença de sintomas, ambas diretamente relacionadas com o stress emocional (o envolvimento com a notícia), como já mencionado. Porém o stress fisiológico também está presente e, se há grande elevação das catecolaminas e do cortisol, a situação pode ficar ainda mais crítica para os sujeitos, porque pode levar a doenças coronarianas.

Analisando-se os sete fatores de avaliação do comportamento tipo A separadamente, verificou-se que os repórteres apresentam altíssimo nível de ambição e os repórteres cinematográficos, nível alto. Esse altíssimo nível de ambição dos repórteres pode ser justificado porque estão mais expostos à opinião pública e desejam alcançar sucesso na carreira profissional, para ganhar também maior visibilidade no vídeo.

A interpretação do teste indica que os sujeitos da pesquisa estão muito centrados nas questões financeiras e não se dispõem a colaborar com algum projeto se não houver benefícios e oportunidade de promoção pessoal ou profissional. O que se observa entre os repórteres é que a remuneração nesses casos é aspecto fundamental de retenção profissional e precisa ser diferenciada para não favorecer a migração para outras emissoras de televisão. Já os repórteres cinematográficos ambicionam crescer profissionalmente, tomando como modelo os seus parceiros repórteres.

O fator "impaciência" também se apresentou em índice altíssimo em repórteres e alto em repórteres cinematográficos. Esse fator pode estar relacionado ao perfil adaptativo do repórter e do repórter cinematográfico à natureza das suas funções. Os sujeitos precisam estar atentos a tudo que possa render uma pauta interessante ou um furo de reportagem e responder com objetividade na hora da tomada de decisão, portanto esse comportamento passa a contaminar as ações dos sujeitos em outras situações, dentro e fora do trabalho. Os sujeitos têm dificuldade de esperar e demonstram comportamento ansioso quando, por força das circunstâncias, necessitam aguardar o resultado de algum processo, pessoa ou situação (no trânsito, à espera do entrevistado, ao buscar o melhor ângulo de captação da imagem). O teste indica que se sentem irritados quando percebem alguém fazendo lenta e calmamente a tarefa que lhe foi designada, preferindo fazê-la eles mesmos. A atividade de reportagem, embora habitual, exige sempre 
soluções novas e rápidas, por isso leva-os a apresentar impaciência para cumprir os curtos prazos de entrega das matérias.

Outro fator avaliado foi o senso de competência, que se apresentou alto nos dois grupos. Parece que o fato de a empresa exigir elevado padrão de desempenho e resultados que atendam plenamente ao esperado, e também o desejo de serem homenageados e reconhecidos por boas coberturas e fatos reveladores, leva os repórteres a se verem como mais competentes que os demais colegas da equipe de trabalho. O teste revela que os sujeitos sugerem saber e fazer melhor que os outros e que, pela grande necessidade de reconhecimento, fazem de tudo para serem elogiados e admirados, colocando-se sempre como centro das atenções.

Os repórteres contam com sua competência e buscam qualificar-se com conhecimentos e atualizações de assuntos diversos, pois constantemente são avaliados pelos resultados e capacitação profissional. Os repórteres cinematográficos também parecem sentir extrema necessidade de reconhecimento e orgulho por captar imagens inéditas que possam agregar valor às reportagens. $\mathrm{O}$ fato de não serem tão enaltecidos quanto os repórteres faz com que queiram receber os mesmos créditos ao realizar uma matéria de sucesso, e quando não recebem isso gera um sentimento de injustiça.

Também se verificou alto nível de nervosismo nos dois grupos. O teste revela que ambos demonstraram perfil com elevada tendência a responder com nervosismo e alta irritabilidade às exigências e demandas do trabalho, a ser hostil ao falar, a responder com pouco autocontrole e impulsivamente e a interpelar ou questionar as pessoas. Os dois grupos tendem a expressar claramente esse comportamento e talvez isso se justifique porque são expostos a enfrentar persistentemente contextos adversos e são cobrados por resultados, não importando as dificuldades que tenham que enfrentar.

Os repórteres revelaram alto nível de auto-sobrecarga e os repórteres cinematográficos, nível médio. Os perfis de repórter e de repórter cinematográfico requerem aguçada curiosidade e senso de oportunidade para buscar informações ou imagens, estejam elas onde estiverem, sem preocupar-se com o senso de limite. O repórter geralmente apura, pesquisa, marca entrevista, escreve o texto e assume várias tarefas simultaneamente. O teste indicou que os sujeitos assumem compromissos mesmo não tendo possibilidade de executá-los, por já estarem muito sobrecarregados com as atividades que têm. Muitas vezes também não sabem recusar convites e pedidos, desde que antevejam neles uma oportunidade de se destacar ou conseguir um furo de 
reportagem. Os repórteres cinematográficos parecem lidar mais adequadamente com esse fato, todavia não deixam de estar com a câmera ligada onde quer que estejam.

O resultado do teste demonstra que os sujeitos têm incapacidade de desligar-se em nível médio. Esse fator mostrou-se menos acentuado que os demais analisados acima, embora seja mais presente nos repórteres do que nos repórteres cinematográficos. A identificação plena com o perfil profissional de jornalista implica estar "antenado" com os acontecimentos, vinte e quatro horas por dia.

De modo geral, os sujeitos da pesquisa revelaram alguma dificuldade em desligar-se de tarefas que tenham para resolver, na medida em que acompanham as notícias e pensam em pautas novas para o dia seguinte. São capazes de interromper alguma atividade de lazer se estiverem diante de algum fato importante que precisa ser anunciado. Muitas vezes se verifica que compromissos familiares e sociais são sacrificados pelo trabalho, por participarem de plantões em portas de delegacias, hospitais etc., que se estendem para além do horário habitual de trabalho.

O fator "urgência de tempo" foi o único que evidenciou resultados significantes nos dois grupos e se apresentou no nível médio, revelando que os sujeitos buscam fazer as atividades com rapidez e no menor espaço de tempo para cumprir os prazos do telejornalismo. O que se verifica é que trabalhar sob pressão de tempo é parte da rotina, inerente à natureza da atividade, e talvez por isso esse fator tenha revelado nível médio.

\section{C) COM RELAÇÃO À COMPETÊNCIA}

Quanto às variáveis "stress" e "competência", os resultados revelam que não há uma correlação significante, porém há aspectos a serem destacados. Os resultados indicaram que $80 \%$ dos repórteres e 70\% dos repórteres cinematográficos demonstraram nível adequado de competência, ou seja, atendem plenamente ao padrão esperado pela empresa. No entanto, o que se verificou nos resultados é que mesmo os repórteres com adequado nível de competência, que obtiveram resultado nível 2, apresentaram elevado nível de presença de sintomas de stress e nível geral de stress médio alto, e que 65\% apresentaram sinais de stress na fase de perigo e perigo agudo. A alta presença de stress também aparece nos sujeitos com baixo nível de competência. 
Verificou-se ainda que sujeitos que se destacam com nível 3 de competência, ou seja, os mais talentosos da empresa e que superam os resultados, obtiveram baixo nível de presença de stress, nível geral de stress médio e se encontram na fase de alarme. De maneira geral, parece que ter mais competências contribui para um menor nível de stress, por possibilitar melhores condições de coping, no entanto esse aspecto precisaria ser mais bem investigado numa amostra maior de sujeitos.

Já no grupo de repórteres cinematográficos não houve sujeitos com nível 3 de competência. O que se verificou foi que o nível de presença de stress aparece entre $70 \%$ dos sujeitos e de forma distribuída entre os níveis 1 (em desenvolvimento) e 2 (atende) de competência, com nível geral de stress principalmente no nível médio alto, e que $60 \%$ dos sujeitos revelaram sinais da fase de perigo e perigo agudo de stress.

\section{D) COM RELAÇÃO AO DESEMPENHO}

Quanto ao estudo das variáveis "stress" e "desempenho" nos repórteres, os resultados indicam que não há correlação significante. Todavia se verificam dados importantes a discutir: 85\% apresentaram elevada presença de sintomas de stress, distribuída de forma heterogênea pelos três níveis de desempenho (ED - em desenvolvimento, A - atende plenamente e S supera); $70 \%$ dos repórteres que apresentaram nível 2 de desempenho (A) demonstraram também nível geral de stress entre nível médio alto e alto; e 65\% evidenciaram características de stress da fase de perigo ou perigo agudo. Embora estejam na fase de resistência de stress, estão beirando a fase de exaustão.

Dos sujeitos que revelam nível 3 de desempenho (S), que são 15\% da amostra total de repórteres, $67 \%$ também demonstraram elevado nível de presença de stress e nível geral de stress que varia de médio a médio alto, mas são os que apresentaram melhores resultados com relação à fase de stress, uma vez que $67 \%$ deles se encontram na fase de alarme, portanto podemos inferir que se utilizam de mecanismos de coping mais adequados. Os sujeitos com nível 3 de desempenho são profissionais de destaque e reconhecidos pela empresa como tal.

Analisando os resultados do grupo de repórteres cinematográficos, verifica-se que os índices são menos elevados se comparados ao grupo de repórteres, porém não menos relevantes. Da mesma maneira, os resultados de stress se distribuem de forma desigual pelos níveis de desempenho, não havendo correlação significante entre stress e desempenho. Porém os índices 
são elevados, já que $70 \%$ dos repórteres cinematográficos apresentam alta presença de sintomas de stress, sendo 5\% dos sujeitos com nível 1 de desempenho (em desenvolvimento), 45\% com nível 2 (atende plenamente) e $20 \%$ com nível 3 (superam o padrão da empresa). O nível geral de stress se mantém predominantemente no nível médio alto e $60 \%$ dos profissionais evidenciaram sinais de stress da fase de perigo e perigo agudo, contra $40 \%$ na fase de alarme.

O stress é fator crucial para o desempenho e mobiliza as pessoas para as tarefas (BENSON, 2005), porém deve ser mantido em níveis moderados. Dado que o índice de stress é elevado entre os telejornalistas, como é elevado o nível de desempenho, podemos inferir que essa correlação é uma resposta vital para o meio altamente competitivo, porém não pode ser sustentada permanentemente, por comprometer a capacidade da percepção e da precisão mais acurada dos telejornalistas e a eficácia do trabalho. Segundo Cohen (1980), as pessoas aumentam o grau de agressividade, ficam menos sensíveis, diminuem a prontidão para colaborar quando estão sob efeito do stress, comprometendo o nível de desempenho.

Considerando os resultados elevados de stress à luz da teoria de demanda e controle (KARASEK, 1979; apud LIMONGE E RODRIGUES, 2002), que associa sobrecarga e autonomia no trabalho, pode-se analisar a interferência desses fatores nos resultados do stress e desempenho em telejornalismo. A primeira possibilidade da elevação do stress é a oposição entre alta demanda e baixo controle, ou seja, quando, por exemplo, os telejornalistas são pressionados a realizar matérias em curto prazo e com grande nível de exposição no vídeo, devido a algum fato dramático, de importância no cenário nacional ou internacional. Nessas ocasiões, há sobrecarga de exigência de trabalho, relativa autonomia para tomar decisões necessárias à execução de suas tarefas, porém pouca liberdade para administrar a seqüência e o tempo de execução do trabalho, o que acarreta alto stress, que pode ser fator de risco à saúde se for algo constante.

Outra possibilidade é a oposição entre alta demanda e alto controle, muito próxima do que os telejornalistas vivenciam cotidianamente: o trabalho ativo. Os sujeitos têm elevado nível de exigência e simultaneamente elevada autonomia, ou seja, desenvolvem novos padrões de comportamento dentro e fora do ambiente de trabalho, são criativos e mostram maior capacitação. Essa abordagem vem ao encontro do trabalho de equipe autogerenciável, que foi percebido na amostra pesquisada, na medida em que a dupla de profissionais atua com relativa 
independência e com grande controle sobre seu trabalho, sem necessitar seguir o direcionamento das chefias.

Outros fatores se mostram presentes na relação entre stress e resultados de desempenho e são moderadores dos níveis de stress, quando este é baixo ou moderado: a interiorização dos valores da cultura organizacional, o compromisso com a organização, comprometimento e sentido do trabalho (crenças, convicções pessoais), que levam as pessoas a mobilizar recursos para enfrentar os obstáculos (LAZARUS E FOLKMAN, 1984; SIU, 2003). Na amostra pesquisada, como o nível geral de stress é médio alto, mas a frequiência e a intensidade são médias, especialmente no grupo de repórteres cinematográficos, podemos considerá-los como fatores que poderão equilibrar positivamente a relação entre stress e desempenho no trabalho.

\section{CORRELAÇÃO ENTRE COMPETÊNCIA E DESEMPENHO}

$\mathrm{Na}$ avaliação dos níveis de competência e de desempenho da amostra pesquisada verificase que $85 \%$ apresentam nível 2 ou 3 de competência e desempenho, perfil este plenamente de acordo com o padrão esperado pela empresa. Os resultados indicam que a correlação entre competência e desempenho é significante e uma variável interage fortemente com a outra. Isso significa que tanto a função de repórter como a de repórter cinematográfico são profissões mistas (Le Boterf, 2003), cujo resultado do trabalho é marcado pelo talento pessoal (habilidades como estilo do texto do repórter, habilidade de estética das imagens no caso dos repórteres cinematográficos) e por um conjunto de itens agregados (os que foram avaliados no instrumento), como conhecimentos, experiência, atualização constante etc.

Os elevados níveis de competência e os resultados de desempenho apresentados têm também relação com o grau de comprometimento dos sujeitos da pesquisa e com as oportunidades que a empresa oferece, que são os desafios. O desafio tem importante implicação adaptativa, eleva o moral dos sujeitos, gera entusiasmo, autoconfiança, possibilitando que as pessoas mobilizem suas competências por inteiro, além de ser um fator moderador dos níveis de stress. 
VIII. CONCLUSÃO 
O presente estudo possibilitou analisar os diferentes níveis de stress e de desempenho dos profissionais de telejornalismo, bem como estabelecer outras intercorrelações significantes, que fizeram ampliar o estudo de variáveis, detalhando-se características comuns e diferenciadas entre as funções de repórter e repórter cinematográfico, como também confirmar o padrão de comportamento tipo A do telejornalista.

Realizar a pesquisa foi uma experiência muito positiva também porque levou à construção de um instrumento de avaliação de desempenho que poderá ser utilizado pela empresa e também à definição do perfil padrão de desempenho, que servirá de parâmetros sobre o que é esperado da atuação das duas categorias profissionais. Nesse sentido, este estudo permitiu a criação de referenciais estruturados de medida de desempenho para as funções de repórter e repórter cinematográfico, situação atualmente ainda pouco sistematizada nas redações.

A pesquisa realizada é de significativa relevância, inclusive porque os resultados contribuem para os estudos sobre o stress relacionado à atividade telejornalística e também porque apontou para a grande carência de diálogo com suas chefias sobre assuntos relativos ao seu processo de desenvolvimento, às suas competências e ao desempenho profissional.

Entende-se que a pesquisa deve ter continuidade, ampliando-se a amostra e contemplando-se um maior universo de emissoras em várias localidades, com o objetivo de expandir as discussões deste trabalho. Outra possibilidade é pesquisar as características dos agrupamentos que influenciaram a formação dos clusters mencionados na pesquisa, examinando o que há de comum no comportamento dos sujeitos.

Em outras palavras, percebe-se a importância de ampliar as fontes de investigação do stress ocupacional em telejornalismo e direcionar o aprofundamento das pesquisas sobre os fatores exógenos e endógenos vinculados ao stress nessa área, uma vez que os resultados apontam para índices de stress bastante expressivos, indicando que a atuação do psicólogo organizacional e do trabalho poderá ser de grande contribuição. 


\section{REFERÊNCIAS BIBLIOGRÁFICAS}




\section{REFERÊNCIAS BIBLIOGRÁFICAS}

- ANDERSON, C. A cauda longa. Do mercado de massa para o mercado de nicho. Rio de Janeiro: Elsevier, 2006.

- ANGERAMI, W.A (Org.). Atualidades em Psicologia da Saúde. São Paulo: Thomson Learning, 2003

- ARVEY, R.; MURPHY, K. Performance evaluation in work settings. Annual Review of Psychology, 1998, 49: 141-68

- AUSTIN, J.; VILlanOVA, P. The Criterion Problem: 1917-1992. Journal of Applied Psychology, 1992, 77 (6): 836-874.

- ATTEWELL, P. What is skill. Work and Occupations, Vol. 17 (4), 1990.

- BARLING, J \& BOSWELL, R. Work performance and the achievement-strivings and impatience-irritability dimensions of Type A Behavior. Applied Psychology: An International Review, 1995, 44(2): 143-153.

- BENSON, H. Estresse, uma questão de equilíbrio. Harward Business Review. 2005, 12 : 35-39.

- BARCELlOS, C. Prefácio - In: Kyrillos, L. (org.), Voz e Corpo na TV: a fonoaudiologia a serviço da comunicação. São Paulo: Globo, 2003.

- BISTANE, L.\& BACELLAR, L. Jornalismo de TV. São Paulo: Contexto, 2005.

- CHANLAT, Jean-François. Modos de gestão, saúde e segurança no trabalho. In: Davel, E. \& Vasconcelos, J. (org), Recursos Humanos e subjetividade. Petrópolis, RJ: Vozes, 1995.

- CHANLAT, Jean-François. Por uma antropologia da condição humana nas organizações

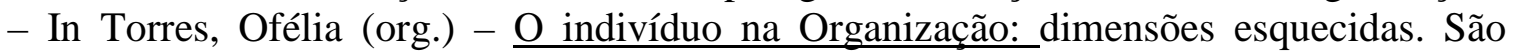
Paulo: Atlas, 1996.

- COELhO, M. A. - Sinais psicofisiológicos e vocais de ativação por stress no telejornalismo ao vivo. Tese Doutorado - USP/SP, 2002.

- COHEN, S. After-effects of stress on human performance and social behavior: a review of research and theory. Psychological Bulletin, 1980, 88, 82-108.

- COOPER, C; BAGLIONI, J. A structural model approach toward the development of a theory of the link between stress and mental health. British Journal of Medical Psychology, 1988, 61, 87-102

- COOPER, C; PAYNE, R. Current concerns in occupational stress. John Wiley \& Sons Ltd: Great Britain, 1980

- DUTRA, J. Gestão por competências: um modelo avançado para o gerenciamento de pessoas. São Paulo: Gente, 2001.

- DUTRA, J. Gestão de pessoas: modelos, processo, tendências e perspectivas. São Paulo: Atlas, 2002.

- DUTRA, J. A gestão de pessoas na empresa moderna - abordagem conceitual e instrumental à luz dos conceitos e competência, complexidade e espaço ocupacional. São Paulo, Tese para o concurso de livre docência . FEA/USP, 2004.

- ENRICHEZ, E. Organização em análise. Petrópolis, RJ: Vozes, 1992.

- EYSENCK, H. Personality, stress and cancer: prediction and prophylaxis. British Journal of Medical Psychology, 1988, 61, 57-74. 
- FEDLER, F. Insiders' Stories: Coping with Newsroom Stress: an Historical Perspective. American Journalism, 2004, 21(3), 77-106.

- FEINSTEIN, A. Journalists under fire. The psychological hazards of covering war. The Baltimore: Johns Hopkins University Press, 2006.

- FERREIRA, M.C. \& ASSMAR, M.L. Cultura, Satisfação e Saúde nas Organizações. In: Tamoyo, A (org). Cultura e Saúde nas Organizações. Porto Alegre: Atmed, 2004.

- GOLDBERG, P. A saúde dos executivos - como identificar sinais de perigo para a saúde e levar a melhor contra o estresse. Rio de Janeiro: Editora Guanabara, 1986.

- GUBA, EGON G., The Paradigm Dialogue, Sage Publications, EUA, 1990.

- GOWLER, D.; LEGGE, K. Evaluative Practices as stressors in occupational settings. In: Cooper, C; Payne, R. Current concerns in occupational stress. John Wiley \& Sons_Ltd: Great Britain, 1980

- GUERRER, F. Stress ocupacional de enfermeiros em unidade de terapia intensiva. Dissertação de Mestrado - USP/SP, 2007.

- HALLOWELL, E. Circuitos sobrecarregados: por que gente inteligente tem um fraco desempenho. Harvard Business Review, pág. 47-53, jan.2005.

- HELOANI, J.R., Mudanças no mundo do trabalho e impactos na qualidade de vida do jornalista. São Paulo: FGV, Núcleo de Pesquisas e Publicações- Série relatórios de pesquisa, $12 / 2003$.

- JAPIASSU, H., Questões Epistemológicas. Rio de Janeiro: Imago, 1981.

- KYRILLOS, L.; COTTES, C.; FEIJÓ, D. Voz e Corpo na TV: a fonoaudiologia a serviço da comunicação. São Paulo: Globo, 2003.

- KRANTZ, D \& RAISEN, S. Enviromental stress, reactivity and ischaemic heart disease. British Journal of Medical Psychology, 1988, 61: 3-16

- LAZARUS, R.S. Personalidade e Adaptação. Rio de Janeiro: Zahar Editores, 1974.

- LAZARUS, R.S., \& FOLKMAN, S. Stress, appraisal and coping. Cap. 2, Cognitive Appraisal Processes. New York: Springer Publishing Company, 1984.

- LAZARUS, R.S., Estrés y Emoción. Manejo e implicaciones en nuestra salud. Bilbao: Desclée de Brouwer, 2000.

- LE BOTERF, G. Desenvolvendo a competência dos profissionais. Porto Alegre: Atmed, 2003.

- LE DOUX, J. O cérebro emocional: os misteriosos alicerces da vida emocional. Rio de Janeiro: Objetiva, 2001. pag. 39-65

- LEITE, J. E. Nós quem cara pálida?: A razão depois de Taylor. In: Davel, E \& Vasconcelos, J. (org), Recursos Humanos e Subjetividade. Petrópolis, RJ: Vozes, 1995.

- LIPP, M; TANGANELLI, M. Stress e qualidade de vida em magistrados da Justiça do Trabalho: diferença entre homens e mulheres. Psicologia: reflexão e crítica, v. 15, n.3, 2002.

- LOSICER, E. A pró-cura da subjetividade: a organização pede análise. In: Davel, E \& Vasconcelos, J. (org), Recursos Humanos e subjetividade. Petrópolis, RJ: Vozes, 1995.

- LIMONGE, F \& RODRIGUES, A. Stress e Trabalho: uma abordagem psicossomática. São Paulo: Atlas, 2002

- MCCLOY, R.; CAMPBELL, J.; CUDECK, R. A confirmatory test of a model of performance determinants. Journal of Applied Psychology (1994),

- MAGNUSSON, D. Situational Determinants of Stress: an Interactional Perspective. In: Goldberger, L.; Breznitz, S.(editores). Handbook of stress - Theoretical and Clinical 
Aspects. 1st Edition. New York, NY: The Free Press, 1982. Part 4, Chapter 15, pág. 231253.

- MALVEZZI, S. Educação e avaliação - avaliação de potencial dos recursos humanos uma força de transformação nas organizações. Cortez, São Paulo, 1980.

- MALVEZZI, S. The man-work relationship na Organizational Change. Ph.D. Thesis. Lancaster, 1988.

- MALVEZZI, S. A Reconfiguração do desenvolvimento profissional no paradigma emergente de gestão. In: Boog, G. (org), Manual de Treinamento e Desenvolvimento ABTD. São Paulo: Makron Books, 1994.

- MALVEZZI, S. "Ponto de mutação desafia relações homem-empresa" - Empresas e Tendências, v.2, n.16, págs 19-23 - agosto/1995.

- MALVEZZI, S. Psicologia Organizacional: da administração científica à globalização, uma história de desafios. In: Machado, C., M. Melo,V. Franco \& N. Santos - Interfaces da Psicologia. Universidade de Évora, Portugal. Actas do Congresso Internacional, Vol.II, 1999.

- MALVEZZI, S. "Coordenação de competências: a força da gestão na sociedade globalizada" - Revista de Marketing Industrial, n.12, 2000.

- MALVEZZI, S. "Paradigma tradicional de gestão e modelo emergente". Folha avulsa disciplina do programa de pós-graduação em psicologia social - PST 5716 - maio de 2004.

- MALVEZZI, S. Prefácio. In: Zanelli et al. Psicologia Organizacional e do Trabalho no Brasil. São Paulo: Armed, 2004.

- MENDES, A. Cultura Organizacional e prazer-sofrimento no trabalho: uma abordagem psicodinâmica. In: Tamoyo, A (org). Cultura e Saúde nas Organizações. Porto Alegre: Atmed, 2004.

- MENDES, A e CRUZ, R. Trabalho e Saúde no contexto organizacional: algumas vicissitudes teóricas. In: Tamoyo, A (org). Cultura e Saúde nas Organizações. Porto

- Alegre: Atmed, 2004.

- MARTELL, R.; BORG, M. A comparison of behavioral rating accuracy of groups and individuals. Journal of Applied Psychology. 1993, 78 (1), 43-50.

- MOTOWIDLO, S.; PACKARD, J; MANNING, M. Occupational stress: its causes and consequences for job performance. Journal of Applied Psychology. 1986, 71 (4), 618629.

- MOTOWIDLO, S.; VAN SCOTTER, J. Evidence that task performance should be distinguished from contextual performance. Journal of Applied Psychology. 1994, 79 (4), 475-480.

- MUSE, L.; STANLEY, H.; FIELD, H. Has the Inverted - U theory of stress and job performance had a fair test?. Human Performance, 2003, v. 16 (4), 349-364.

- NITSCH, JURGEN et al. Stress - Theorien, Untersuchungen, Massnahmen. Berna, Alemanha, Verlag Hans Huber, 1981, cap. 1, págs 52 - 84.

- OBERLECHNER, T; NIMGADE,A. Work stress and performance among financial traders. Stress \& Health: Journal of the International Society for the Investigation of Stress. 2005, 21(5), 285-289.

- O'DRISCOLL, M; BEEHR, T. Supervisor behaviors, role stressors and uncertainty as predictors of personal outcomes for subordinates. Journal of Organizational Behavior, 1994, 15, 141-145. 
- PAZ, M.G. - Justiça distributiva na avaliação de desempenho dos trabalhadores de uma empresa estatal. Tese Doutorado - USP/SP, 1992.

- PEREIRA, L.P - Voz e stress no cotidiano de professoras disfônicas. Dissertação de Mestrado - PUC/SP, 2003.

- ROUSSEAU, D. Organizational Behavior in the New Era. Annual Review of Psychology, 1997, 48.

- REINARDY, S. Newspaper journalism in crisis: Burnout on the rise, eroding young journalists' career commitment. Folha avulsa aceita para a apresentação na Convenção da Divisão de Jornal da Associação para a Educação em Jornalismo e Comunicação de Massa, Washington, D.C., Agosto 2007.

- ROUSSEAU, D. Organizational Behavior in the New Era. Annual Review of Psychology, 1997, 48.

- SALERNO, M. Trabalho e organização na empresa industrial integrada e flexível. In: Ferretti, C.J. Novas tecnologias, trabalho e educação: um debate multidisciplinar, Petrópolis, RJ: Vozes, 1994.

- SANTOS, N. Cultura organizacional e desempenho: pesquisa, teoria e aplicação. São Paulo, Stiliano, 2000.

- SAMPAIO, J. R. Psicólogo Organizacional e do trabalho: teoria, pesquisa e temas correlatos. In: Goulart, I. B. (org). Implantação de gestão de competências em empresa brasileira de telecomunicações. São Paulo: Casa do Psicólogo, 2002.

- SATO, L. Saúde e controle no trabalho - feições de um antigo problema. In: Jacques, M.G.; Codo, W. (Org.). Leituras em Saúde Mental \& Trabalho. 1a ed. Petrópolis: Vozes, 2002, v. 1, p. 31-49.

- SELYE, H. Stress: a tensão da vida. 2 ed. Tradução de Frederico Branco. São Paulo, Ibrasa, 1965.

- SELYE, H. History and present status of the stress concept. In: Goldberger, Leo; Breznitz, Shlomo (editores). Handbook of stress - Theoretical and clinical aspects. 1st Edition. New York, NY: The Free Press, 1982. Part 1, Chapter 2, p.7-17.

- SIU, O. Job stress and job performance among employees in Hong Kong: the role of chinese work in the values and organizational commitment. International Journal of Psychology. 2003, 38 (6), 337-347.

- SOLOMON,G. Psiconeuroimunologia: synopsis de su historia, evidencia y consecuencias. Segundo Congresso Virtual de Psiquiatria, Interpsiquis, 2001.

- SPENCER, L., SPENCER, S., Competence at work: models for superior performance. New York: John Willey, 1993.

- TAMOYO, A \& LIMA,D \& SILVA, A. Clima Organizacional e Stress no trabalho. In: Tamoyo, A (org). Cultura e Saúde nas Organizações. Porto Alegre: Atmed, 2004.

- VASCONCELlOS, E.G. Tópicos de Psiconeuroimunologia. São Paulo: Editorial Ipê, 2000.

- VASCONCELLOS, E.G. O modelo psiconeuroimunológico do stress. In: Seger, L. Psicologia e Odontologia - uma abordagem integradora - Livraria Santos, São Paulo, 2002.

- VISWESVARAN, C; ONES, D; SCHMIDT, F. Comparative analysis of the reliability of job performance ratings. Journal of Applied Psychology. 1996, 81(5), 557-574.

- TASSARA, EDA. A Psicologia Social e o enfrentamento da crise ambiental - texto apresentado na prova de erudição para a obtenção de título de professora titular no Departamento da PST do IP/USP -05/05/2006. 
- YORKE, I. Jornalismo diante das câmeras. São Paulo: Summus, 1998.

- WESTMAN, M \& EDEN, D. The inverted - U relationship between stress and performance: a field study. Work \& Stress, 1996, v. 10, 2, 165-173.

- WHEATLEY, M. Liderança para tempo de incerteza: a descoberta de um novo caminho. São Paulo: Cultrix, 2006.

- WINES, M. Burnout in the Newsroom. Washington Journalism Review. May 1986, 35.

- WITTORSKI, R. Da fabricação das competências. In: Tomasi, A (org), Da qualificação à competência: pensando o século XXI. Campinas, SP: Papirus, 2004.

- WOEHR, D. Understanding frame-of-reference training: the impact of training on the recall of performance information. Journal of Applied Psychology. 1994, 79 (4), 525534.

- WOLTON, D. Elogio do grande público: uma teoria crítica da televisão. São Paulo: Ática, 2006. 


\section{ANEXOS}


Sujeito: (número)

Sexo:

Idade:

Estado civil:

$\mathbf{N}^{\circ}$ de filhos e idade:

Grau de instrução:

Formação profissional:

Tempo de empresa:

Tempo de profissão:

$\mathbf{N}^{\circ}$ de horas trabalhadas (considerar a soma dos 2 empregos)

Tem outro emprego em paralelo: 


\begin{tabular}{|c|c|}
\hline Requisitos do Cargo & $\begin{array}{l}\text { A atuação no cargo de repórter exige curso de formação } \\
\text { em Comunicação Social, com habilitação em Jornalismo } \\
\text { e apresentação de registro profissional. } \\
\text { É uma função especializada, de característica técnica, ou } \\
\text { seja, não há responsabilidade por gestão de pessoas ou } \\
\text { recursos (materiais e orçamentários), porém a atuação em } \\
\text { telejornalismo diferencia-se pela complexidade da } \\
\text { matéria realizada e desafios propostos aos profissionais. } \\
\text { Para que o profissional possa assumir suas funções em } \\
\text { televisão, além da graduação específica, precisa dispor de } \\
\text { habilidades e competências técnicas, tais como vivência e } \\
\text { conhecimentos, que na prática se traduzem por adequada } \\
\text { contribuição para o telejornal que atua, frente aos } \\
\text { resultados esperados pela empresa. } \\
\text { Experiência é a prática profissional na realização de } \\
\text { matérias jornalísticas e o domínio da linguagem técnica } \\
\text { de televisão. Já os conhecimentos necessários estão } \\
\text { voltados para o nível de domínio da língua portuguesa e } \\
\text { do idioma inglês falado, a técnica de expressão no vídeo, } \\
\text { o contato com fontes jornalísticas, a prática em produção } \\
\text { de reportagem e edição, bem como o uso que faz de } \\
\text { tecnologia (informática e edição não linear). }\end{array}$ \\
\hline Descrição Sumária & $\begin{array}{l}\text { Acompanha pessoalmente acontecimentos políticos, } \\
\text { sociais, esportivos, artísticos e religiosos, bem como } \\
\text { planeja, organiza e busca notícias ou informações sobre } \\
\text { assuntos predeterminados, realizando entrevistas e } \\
\text { reportagens, e selecionando-as para veiculação em } \\
\text { televisão, no instante e local em que ocorram, ou } \\
\text { posteriormente ao fato ocorrido. }\end{array}$ \\
\hline Descrição Detalhada & $\begin{array}{l}\text { Tem como responsabilidades as seguintes tarefas e } \\
\text { atribuições: } \\
\text { - planeja, apura e pesquisa informações previamente a } \\
\text { fim de preparar-se para as coberturas ou reportagens, } \\
\text { buscando qualidade e profundidade da matéria, } \\
\text { - realiza contatos com fontes que possam agregar } \\
\text { informações importantes, colaborando com o trabalho da } \\
\text { produção e da edição de reportagem, } \\
\text { - pauta notícias, participa de reuniões, oferece ou toma } \\
\text { conhecimento da matéria do dia, } \\
\text { - recolhe e redige informações "quentes" sobre assuntos } \\
\text { de interesse público, como notícias que acabaram de }\end{array}$ \\
\hline
\end{tabular}




\begin{tabular}{|c|c|}
\hline & $\begin{array}{l}\text { acontecer (factuais), acidentes, crimes, investigações, } \\
\text { atos públicos, acontecimentos esportivos, etc. } \\
\text { - faz entrevistas noticiando os fatos de modo a elucidá-los } \\
\text { ao público, } \\
\text { - orienta o repórter cinematográfico nas gravações das } \\
\text { reportagens, indicando ou sugerindo ângulos que possam } \\
\text { representar maior interesse do público, para assegurar } \\
\text { maior documentação do evento, } \\
\text { - elabora textos sobre as matérias adequando-os às } \\
\text { imagens, de forma objetiva e dentro dos prazos de } \\
\text { entrega, atendendo aos padrões de linguagem gramatical } \\
\text { e editorial, } \\
\text { - Transmite a notícia para o telejornal, que pode ser ao } \\
\text { vivo ou pré-gravada, passando sua imagem com } \\
\text { credibilidade, } \\
\text { - Monitora o tempo de duração da duração da matéria } \\
\text { para que não exceda à previsão da grade de programação } \\
\text { do telejornal, } \\
\text { - Revela autonomia para elaboração das matérias, com } \\
\text { tomada de decisão dentro do escopo de responsabilidade } \\
\text { do cargo. }\end{array}$ \\
\hline Condições de trabalho & $\begin{array}{l}\text { Desloca-se ao local indicado utilizando-se de meios de } \\
\text { transporte disponíveis, e nesse ambiente, faz uso do } \\
\text { microfone e posicionamento de câmeras. } \\
\text { O computador é seu instrumento de trabalho tanto em } \\
\text { campo quanto em ambiente fechado, e na redação } \\
\text { também se utiliza dos recursos do centro de } \\
\text { documentação e das ilhas de edição, local onde a } \\
\text { decupagem e a edição das matérias são realizadas. } \\
\text { Costuma desenvolver as atividades em horários flexíveis } \\
\text { (manhã, tarde, noite), podendo trabalhar também à } \\
\text { distância, quando requisitado a fazer coberturas especiais } \\
\text { e viagens. }\end{array}$ \\
\hline
\end{tabular}


DESCRIÇÃO DE CARGO - REPÓRTER CINEMATOGRÁFICO

\begin{tabular}{|c|c|}
\hline Requisitos do Cargo & $\begin{array}{l}\text { A atuação no cargo de repórter cinematográfico exige } \\
\text { formação em ensino médio ( } 2^{\circ} \text { grau completo) e } \\
\text { apresentação de registro profissional. Na empresa } \\
\text { pesquisada, o requisito formação acadêmica para esse } \\
\text { cargo é considerado muito importante para o perfil do } \\
\text { profissional, e portanto, é valorizada a habilitação em } \\
\text { jornalismo ou outro curso de nível superior. } \\
\text { Repórter cinematográfico é uma função especializada, em } \\
\text { que o ocupante do cargo precisa dispor de habilidades e } \\
\text { competências técnicas destacadas, tais como a } \\
\text { experiência prática na captação de imagens de assuntos } \\
\text { de interesse jornalístico e conhecimentos do uso da } \\
\text { câmera, técnicas de iluminação, enquadramento, planos, } \\
\text { fotografia, narrativa visual e edição de imagem. } \\
\text { Há outros conhecimentos complementares que também } \\
\text { são necessários, voltados para o domínio do kit } \\
\text { correspondente e do idioma inglês falado. }\end{array}$ \\
\hline Descrição Sumária & Capta e registra imagens e fatos de interesse jornalístico. \\
\hline Descrição Detalhada & $\begin{array}{l}\text { Tem como responsabilidades as seguintes tarefas e } \\
\text { atribuições: } \\
\text { - participa de reuniões de pauta, a fim de sugerir idéias } \\
\text { novas que possam agregar ao trabalho do telejornal, } \\
\text { - toma conhecimento prévio sobre as matérias a serem } \\
\text { realizadas no dia, analisa as características e finalidades, } \\
\text { para que possa planejar seu trabalho e gravar imagens } \\
\text { compatíveis com as coberturas ou reportagens, } \\
\text { - realiza contatos com fontes que possam agregar } \\
\text { informações importantes, colaborando com o trabalho da } \\
\text { produção e da edição de imagem, } \\
\text { - opera a câmera segundo as orientações técnicas, } \\
\text { ajustando o enquadramento, a iluminação, níveis de cor, } \\
\text { buscando manter o equilíbrio na composição da imagem, } \\
\text { - orienta outros profissionais ligados à preparação da } \\
\text { gravação, iluminação, funcionamento da câmera e de } \\
\text { outros equipamentos, para assegurar a qualidade da } \\
\text { imagem, } \\
\text { - capta imagens relacionadas a uma ampla diversidade de } \\
\text { assuntos, movimentando a câmera segundo as } \\
\text { características do entrevistado ou tema enfocado, para }\end{array}$ \\
\hline
\end{tabular}




\begin{tabular}{|l|l|}
\hline | & $\begin{array}{l}\text { transmitir eventos esportivos, fatos dramáticos ou outros } \\
\text { tipos de acontecimentos, } \\
\text { - registra imagens, indicando ângulos que possam } \\
\text { representar maior interesse do público, colaborando com } \\
\text { o trabalho do repórter, } \\
\text { - trabalha com agilidade e dentro dos prazos de entrega, } \\
\text { atendendo aos padrões editoriais, } \\
\text { - revela autonomia para gravar imagens "furos de } \\
\text { reportagem", noticiando os fatos de modo a agregar e } \\
\text { assegurar documentação sobre os assuntos. }\end{array}$ \\
\hline Condições de trabalho & $\begin{array}{l}\text { Faz uso de câmera portátil, kit correspondente e outros } \\
\text { equipamentos necessários ao desenvolvimento do } \\
\text { trabalho. Apesar de a câmera ter reduzido de peso, de } \\
\text { tamanho e estar mais leve, o repórter cinematográfico } \\
\text { carrega o equipamento até o local para o manuseio e uso. } \\
\text { Geralmente a atividade é em campo, fora da emissora, } \\
\text { deslocando -se ao local indicado, através dos meios de } \\
\text { transporte disponíveis. } \\
\text { Os horários de trabalho são flexíveis (manhã, tarde, } \\
\text { noite), podendo trabalhar também à distância, quando } \\
\text { requisitado a fazer coberturas especiais e viagens. }\end{array}$ \\
\hline
\end{tabular}


ANEXO 3 A-

PLANILHA DE AVALIAÇÃ̃ - R

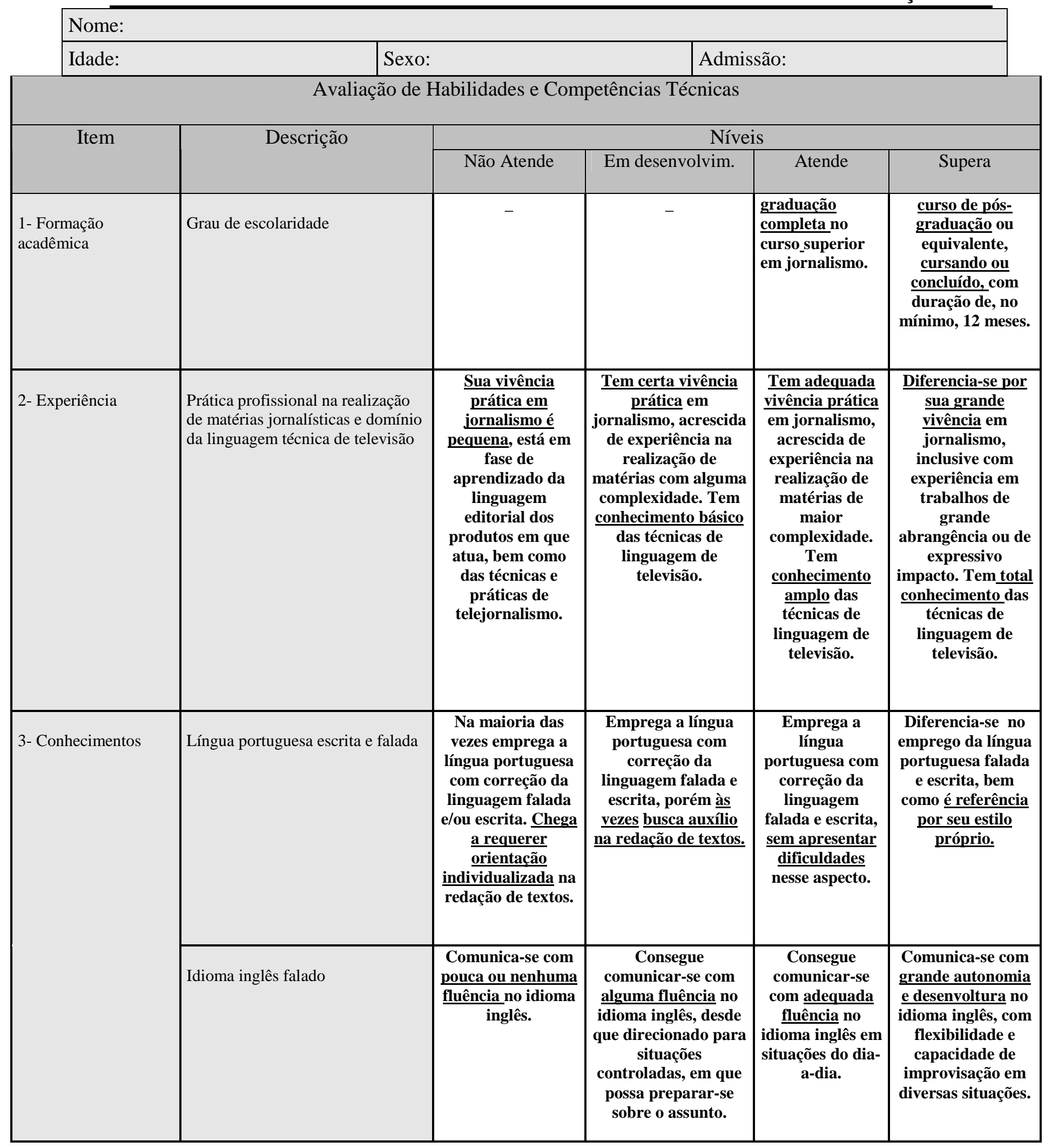




\begin{tabular}{|c|c|c|c|c|c|}
\hline \multicolumn{6}{|c|}{ Avaliação de Habilidades e Competências Técnicas } \\
\hline \multirow[t]{2}{*}{ Item } & \multirow[t]{2}{*}{ Descrição } & \multicolumn{4}{|c|}{ Níveis } \\
\hline & & Não Atende & Em desenv. & Atende & Supera \\
\hline \multirow[t]{4}{*}{$\begin{array}{l}\text { 3- Conhecimentos } \\
\text { (continuação) }\end{array}$} & $\begin{array}{l}\text { Técnica de } \\
\text { expressão no vídeo } \\
\text { (uso da voz, } \\
\text { naturalidade no } \\
\text { vídeo e adequado } \\
\text { uso dos } \\
\text { equipamentos) }\end{array}$ & $\begin{array}{c}\text { Apresenta-se no } \\
\text { vídeo com pouca } \\
\text { espontaneidade. } \\
\text { Faz uso bastante } \\
\text { limitado dos } \\
\text { recursos da voz } \\
\text { bem como dos } \\
\text { equipamentos de } \\
\text { vídeo (microfone, } \\
\text { posicionamento de } \\
\text { câmeras). }\end{array}$ & $\begin{array}{c}\text { Apresenta-se no } \\
\text { vídeo com certa } \\
\text { naturalidade. Usa os } \\
\text { recursos da voz e os } \\
\text { equipamentos de } \\
\text { forma ainda parcial } \\
\text { (microfone, } \\
\text { posicionamento de } \\
\text { câmeras). Está em } \\
\text { processo de } \\
\text { desenvolvimento } \\
\text { para adequar-se às } \\
\text { exigências do vídeo. }\end{array}$ & 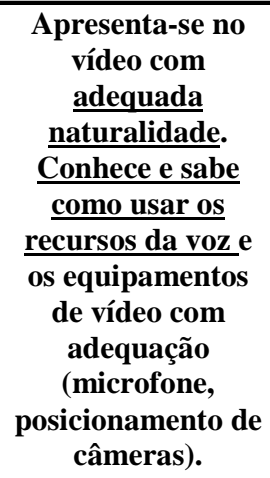 & $\begin{array}{c}\text { Apresenta-se no } \\
\text { vídeo com grande } \\
\text { desenvoltura e } \\
\text { espontaneidade. } \\
\begin{array}{c}\text { Sabe fazer bom } \\
\text { uso dos recursos }\end{array} \\
\underline{\text { da voz e dos }} \\
\text { equipamentos de } \\
\text { vídeo (microfone, } \\
\text { posicionamento de } \\
\text { câmeras). }\end{array}$ \\
\hline & Fontes & $\begin{array}{c}\text { Seu acesso às } \\
\text { fontes externas é } \\
\text { insuficiente e } \\
\text { depende } \\
\text { totalmente da } \\
\text { produção para a } \\
\text { obtenção de } \\
\text { informações. }\end{array}$ & $\begin{array}{l}\text { Seu acesso às fontes } \\
\text { externas ainda é } \\
\text { pouco satisfatório e } \\
\text { depende de forma } \\
\text { parcial da produção } \\
\text { para a obtenção de } \\
\text { informações. }\end{array}$ & $\begin{array}{c}\text { Tem adequado } \\
\text { acesso às fontes } \\
\text { externas e não } \\
\text { depende } \\
\text { exclusivamente do } \\
\text { trabalho da } \\
\text { produção. }\end{array}$ & $\begin{array}{c}\text { Tem amplo acesso } \\
\text { às fontes externas, } \\
\text { sendo diferencial } \\
\text { no mercado } \\
\text { jornalístico. É } \\
\text { independente e } \\
\text { colabora bastante } \\
\text { com informações } \\
\text { para o trabalho da } \\
\text { produção. }\end{array}$ \\
\hline & $\begin{array}{l}\text { Produção de } \\
\text { reportagem e } \\
\text { edição }\end{array}$ & $\begin{array}{c}\text { Tem escasso } \\
\text { conhecimento } \\
\text { sobre apuração e } \\
\text { elaboração de } \\
\text { pautas para a } \\
\text { reportagem e } \\
\text { linguagem de } \\
\text { edição. }\end{array}$ & $\begin{array}{l}\text { Tem conhecimento } \\
\text { satisfatório sobre } \\
\text { apuração e } \\
\text { elaboração de pautas } \\
\text { para a reportagem e } \\
\text { linguagem de edição. }\end{array}$ & $\begin{array}{c}\text { Sabe apurar e } \\
\text { elaborar pautas } \\
\text { para a reportagem } \\
\text { e conhece a } \\
\text { linguagem de } \\
\text { edição. }\end{array}$ & $\begin{array}{c}\text { Diferencia-se pelo } \\
\text { conhecimento da } \\
\text { apuração e da } \\
\text { elaboração de } \\
\text { pautas para a } \\
\text { reportagem e da } \\
\text { linguagem de } \\
\text { edição. }\end{array}$ \\
\hline & $\begin{array}{l}\text { Tecnologia } \\
\text { (informática e } \\
\text { edição não linear) }\end{array}$ & $\begin{array}{l}\text { Não conhece as } \\
\text { tecnologias de } \\
\text { apoio ao } \\
\text { jornalismo, nem } \\
\text { mesmo as de uso } \\
\text { diário. }\end{array}$ & $\begin{array}{l}\text { Conhece pouco as } \\
\text { tecnologias de apoio } \\
\text { ao jornalismo, com } \\
\text { alguma noção dos } \\
\text { equipamentos de uso } \\
\text { diário. }\end{array}$ & $\begin{array}{c}\text { Tem adequados } \\
\text { conhecimentos das } \\
\text { tecnologias de } \\
\text { apoio ao } \\
\text { jornalismo e } \\
\text { conhece } \\
\text { equipamentos } \\
\text { além daqueles de } \\
\text { uso diário. }\end{array}$ & $\begin{array}{c}\text { Tem domínio } \\
\text { sobre tecnologia e } \\
\text { equipamentos mais } \\
\text { complexos de } \\
\text { apoio ao } \\
\text { jornalismo. Tem } \\
\text { autonomia e usa } \\
\text { com habilidade os } \\
\text { recursos técnicos } \\
\text { disponíveis. }\end{array}$ \\
\hline & & & & & \\
\hline
\end{tabular}




\begin{tabular}{|c|c|c|c|c|c|}
\hline \multicolumn{6}{|c|}{ Avaliação de Desempenho } \\
\hline \multirow{2}{*}{ Item } & \multirow[b]{2}{*}{ Descrição } & \multicolumn{4}{|c|}{ Níveis } \\
\hline & & NA & ED & $\mathrm{A}$ & $S$ \\
\hline $\begin{array}{l}\text { 1- Visão do } \\
\text { processo }\end{array}$ & $\begin{array}{l}\text { Realiza suas atividades com profundo conhecimento do } \\
\text { processo de produção da notícia da pauta à edição, em } \\
\text { qualquer produto jornalístico. }\end{array}$ & & & & \\
\hline $\begin{array}{l}\text { 2- Cumprimento de metas e } \\
\text { resultados }\end{array}$ & $\begin{array}{l}\text { Entrega reportagens dentro dos prazos estabelecidos, } \\
\text { adequadas para exibição em qualquer produto jornalístico } \\
\text { (diferentes jornais e programas da emissora), tanto do ponto } \\
\text { de vista técnico quanto editorial. Tem foco na notícia e } \\
\text { consegue adequar o texto à imagem. }\end{array}$ & & & & \\
\hline 3- Trabalho em equipe & $\begin{array}{l}\text { Relaciona-se com os profissionais da redação e de outras } \\
\text { áreas da empresa de forma colaboradora e flexível, } \\
\text { revelando senso de equipe. }\end{array}$ & & & & \\
\hline 4 - Inovação & $\begin{array}{l}\text { Apresenta idéias inovadoras para a realização de matérias } \\
\text { jornalísticas. }\end{array}$ & & & & \\
\hline $\begin{array}{l}\text { 5- Comprometimento } \\
\text { Profissional }\end{array}$ & $\begin{array}{l}\text { Oferece rotineiramente pautas viáveis, fundamentadas em } \\
\text { levantamento prévio de informações e colabora nas } \\
\text { atividades da redação. }\end{array}$ & & & & \\
\hline 6- Qualidade de Texto & $\begin{array}{l}\text { Redige matérias claras, corretas (em informações e na língua } \\
\text { portuguesa), adequadas à linha editorial. }\end{array}$ & & & & \\
\hline 7- Planejamento e Análise & $\begin{array}{l}\text { Mantém-se informado e atualizado diariamente, e realiza } \\
\text { pesquisa aprofundada sobre os assuntos em pauta. } \\
\text { Desenvolve planejamento cuidadoso ao realizar uma } \\
\text { reportagem, bem como analisa, interpreta e correlaciona } \\
\text { informações com boa base crítica. }\end{array}$ & & & & \\
\hline $\begin{array}{l}\text { 8- Comunicação e Imagem no } \\
\text { Vídeo }\end{array}$ & $\begin{array}{l}\text { Transmite cuidado com a imagem visual, credibilidade e } \\
\text { empatia junto ao público, bem como se expressa com clareza, } \\
\text { segurança e domínio da situação no vídeo. }\end{array}$ & & & & \\
\hline $\begin{array}{l}\text { 9- Atualização } \\
\text { Profissional }\end{array}$ & $\begin{array}{l}\text { Participa de atividades que promovem autodesenvolvimento } \\
\text { e busca expandir conhecimentos de forma contínua (leitura } \\
\text { de livros e cultura em geral, cursos técnicos em jornalismo ou } \\
\text { em outras áreas, documentários, cinema, idiomas). }\end{array}$ & & & & \\
\hline \multicolumn{6}{|l|}{ Média (Nível de Desempenho): } \\
\hline Conceituação dos níveis: & \multicolumn{5}{|c|}{$\begin{array}{l}\text { NA - (0) Não atende ao desempenho do cargo } \\
\text { ED- (1) Está em processo de desenvolvimento } \\
\text { A- (2) Atende plenamente ao desempenho do cargo } \\
\text { S- (3) Supera o desempenho do cargo }\end{array}$} \\
\hline $\begin{array}{l}\text { Nível de Habilidades e } \\
\text { Competência Técnica }\end{array}$ & & & & & \\
\hline
\end{tabular}

\begin{tabular}{|l|l|}
\hline Nível de Desempenho & \\
\hline
\end{tabular}




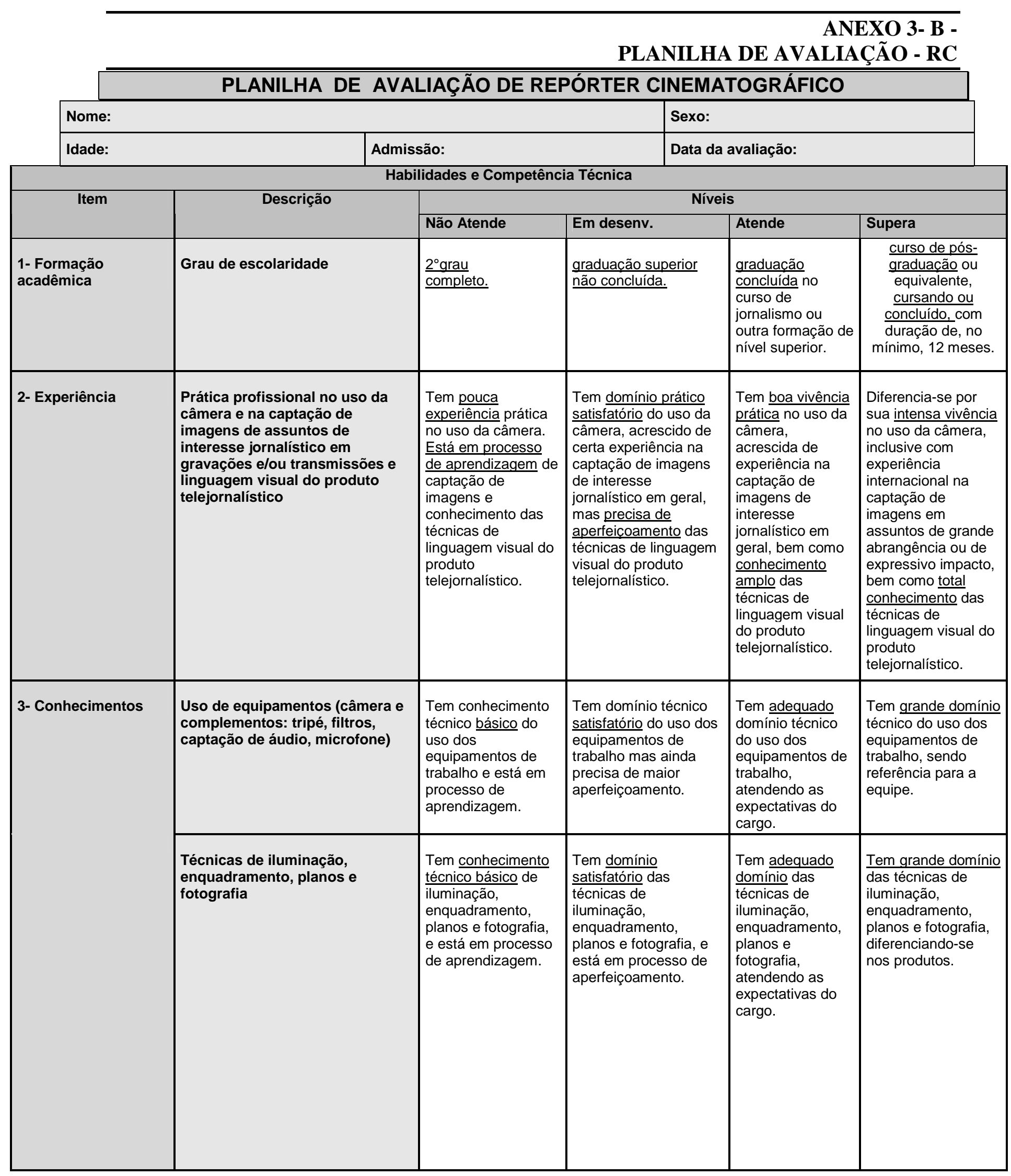




\begin{tabular}{|c|c|c|c|c|c|}
\hline \multicolumn{6}{|c|}{ Habilidades e Competência Técnica } \\
\hline \multirow[t]{2}{*}{ Item } & \multirow[t]{2}{*}{ Descrição } & \multicolumn{4}{|c|}{ Níveis } \\
\hline & & Não Atende & Em desenv. & Atende & Supera \\
\hline \multirow[t]{4}{*}{$\begin{array}{l}\text { 3- Conhecimentos } \\
\text { (continuação) }\end{array}$} & $\begin{array}{l}\text { Técnicas de narrativa } \\
\text { visual (planejamento, } \\
\text { roteiro, percepção da } \\
\text { notícia e texto) }\end{array}$ & $\begin{array}{l}\text { Conhece de forma } \\
\text { limitada as técnicas de } \\
\text { narrativa visual. }\end{array}$ & $\begin{array}{l}\text { Conhece de forma } \\
\text { satisfatória as } \\
\text { técnicas de narrativa } \\
\text { visual. Está em } \\
\text { processo de } \\
\text { treinamento para } \\
\text { melhor adequar a } \\
\text { captação de } \\
\text { imagem para a } \\
\text { reportagem e } \\
\text { edição. }\end{array}$ & $\begin{array}{l}\text { Tem adequado } \\
\text { domínio das } \\
\text { técnicas de narrativa } \\
\text { visual, e capta } \\
\text { imagens } \\
\text { apropriadas para a } \\
\text { reportagem e } \\
\text { edição. }\end{array}$ & $\begin{array}{l}\text { Conhece em } \\
\text { profundidade as } \\
\text { técnicas de narrativa } \\
\text { visual. Sabe captar } \\
\text { imagens de grande } \\
\text { impacto para a } \\
\text { reportagem, e que } \\
\text { contém informação } \\
\text { que pode determinar } \\
\text { a edição. }\end{array}$ \\
\hline & Kit correspondente & $\begin{array}{l}\text { Tem apenas noç̃os do } \\
\text { kit correspondente. }\end{array}$ & $\begin{array}{l}\text { Conhece o kit } \\
\text { correspondente de } \\
\text { forma parcial, } \\
\text { precisando de } \\
\text { reciclagem. }\end{array}$ & $\begin{array}{l}\text { Conhece o kit } \\
\text { correspondente de } \\
\text { forma adequada. }\end{array}$ & $\begin{array}{l}\text { Conhece bastante o } \\
\text { kit correspondente, } \\
\text { sendo referência } \\
\text { nesse assunto, } \\
\text { podendo repassar } \\
\text { conhecimentos para } \\
\text { outros profissionais. }\end{array}$ \\
\hline & Edição de Imagem & $\begin{array}{l}\text { Conhece a linguagem } \\
\text { de edição de imagem } \\
\text { de forma limitada. }\end{array}$ & $\begin{array}{l}\text { Conhece a } \\
\text { linguagem de edição } \\
\text { de imagem de forma } \\
\text { parcial, precisando } \\
\text { de aprofundamento. }\end{array}$ & $\begin{array}{l}\text { Conhece a } \\
\text { linguagem de edição } \\
\text { de imagem de forma } \\
\text { adequada e } \\
\text { influencia as } \\
\text { matérias. }\end{array}$ & $\begin{array}{l}\text { Conhece bastante a } \\
\text { linguagem de edição } \\
\text { e chega a antecipar } \\
\text { imagens que se } \\
\text { adequam } \\
\text { plenamente às } \\
\text { matérias, } \\
\text { melhorando o } \\
\text { produto. }\end{array}$ \\
\hline & Idioma inglês falado & $\begin{array}{l}\text { Comunica-se com } \\
\text { pouca ou nenhuma } \\
\text { fluência no idioma } \\
\text { inglês. }\end{array}$ & $\begin{array}{l}\text { Consegue } \\
\text { comunicar-se com } \\
\text { alguma fluência no } \\
\text { idioma inglês, desde } \\
\text { que direcionado } \\
\text { para situações } \\
\text { controladas, em que } \\
\text { possa preparar-se } \\
\text { sobre o assunto. }\end{array}$ & $\begin{array}{l}\text { Consegue } \\
\text { comunicar-se com } \\
\text { adequada fluência } \\
\text { no idioma inglês em } \\
\text { situações do dia-a- } \\
\text { dia. }\end{array}$ & $\begin{array}{l}\text { Comunica-se com } \\
\text { grande autonomia e } \\
\text { desenvoltura no } \\
\text { idioma inglês, com } \\
\text { flexibilidade e } \\
\text { capacidade de } \\
\text { improvisação em } \\
\text { diversas situações. }\end{array}$ \\
\hline
\end{tabular}

Conceituação dos níveis:
NA - (0) Não atende ao desempenho do cargo

ED- (1) Está em processo de desenvolvimento

A- (2) Atende plenamente ao desempenho do cargo

S- (3) Supera o desempenho do cargo 


\begin{tabular}{|c|c|c|c|c|c|}
\hline \multicolumn{6}{|c|}{ Desempenho } \\
\hline \multirow[b]{2}{*}{ Item } & \multirow[b]{2}{*}{ Descrição } & \multicolumn{4}{|c|}{ Níveis } \\
\hline & & NA & ED & $\mathbf{A}$ & $\mathrm{S}$ \\
\hline $\begin{array}{l}\text { 1- Visão do } \\
\text { processo }\end{array}$ & $\begin{array}{l}\text { Realiza suas atividades com profundo conhecimento do processo de } \\
\text { produção da notícia em qualquer produto jornalístico - da pauta à } \\
\text { edição. }\end{array}$ & & & & \\
\hline $\begin{array}{l}\text { 2- Cumprimento de metas } \\
\text { e resultados }\end{array}$ & $\begin{array}{l}\text { Entrega o material cinematográfico dentro dos prazos estabelecidos, } \\
\text { sem prejuízo da qualidade técnica e com adequação editorial aos } \\
\text { produtos (diferentes jornais ou programas da emissora). }\end{array}$ & & & & \\
\hline 3- Trabalho em equipe & $\begin{array}{l}\text { Relaciona-se com colegas - da externa e da redação - de forma } \\
\text { colaboradora e flexível, revelando senso de trabalho em equipe. } \\
\text { Contribui na rotina profissional para o desenvolvimento do trabalho } \\
\text { de todos. }\end{array}$ & & & & \\
\hline 4 - Inovação & $\begin{array}{l}\text { Oferece idéias inovadoras na realização de matérias jornalísticas. } \\
\text { Sugere novas metodologias para o desenvolvimento do trabalho e } \\
\text { do grupo. }\end{array}$ & & & & \\
\hline 5- Senso de oportunidade & $\begin{array}{l}\text { Faz captação com agilidade, é atento ao que se passa ao redor, e } \\
\text { cria oportunidades, buscando imagens diferenciadas (flagrantes e } \\
\text { furos). }\end{array}$ & & & & \\
\hline $\begin{array}{l}\text { 6- Participação } \\
\text { jornalística }\end{array}$ & $\begin{array}{l}\text { Mantém-se informado sobre as notícias e participa ativamente da } \\
\text { reportagem em que está envolvido (sugestão de imagens, pautas e } \\
\text { indicação de fontes). }\end{array}$ & & & & \\
\hline 7- Comprometimento & $\begin{array}{l}\text { Compreende as necessidades do jornalismo, é pontual, dedicado e } \\
\text { responsável. Tem consciência da repercussão de suas atitudes no } \\
\text { trabalho e sabe equilibrar interesses pessoais com os da empresa. }\end{array}$ & & & & \\
\hline $\begin{array}{l}\text { 8- Atualização } \\
\text { profissional }\end{array}$ & $\begin{array}{l}\text { Participa de atividades que promovem autodesenvolvimento e busca } \\
\text { expandir conhecimentos de forma contínua (leitura de livros e } \\
\text { cultura em geral, cursos técnicos, documentários, cinema, idiomas) } \\
\text { e compartilha os conhecimentos com os colegas de profissão. }\end{array}$ & & & & \\
\hline eqla: & & & & & \\
\hline
\end{tabular}

Conceituação dos níveis:
NA - (0) Não atende ao desempenho do cargo

ED- (1) Está em processo de desenvolvimento

A- (2) Atende plenamente ao desempenho do cargo

S- (3) Supera o desempenho do cargo 


\section{ANEXO 4 \\ VALIDAÇÃO DE CONTEÚDO}

Juiz 1,

Você colaborou muito com a validação da planilha de Avaliação de Desempenho de repórter e repórter cinematográfico e fez observações que alguns itens precisariam ficar mais claros.

Tendo em vista a sua sugestão, reformulamos esses itens para aprimorarmos ainda mais a compreensão. Abaixo segue a sua sugestão e a reformulação realizada. Por favor assinale sim, se acha que o item ficou mais claro com a alteração feita ou não, se o item ainda precisa ser melhorado.

\begin{tabular}{|c|c|}
\hline & Na planilha de repórter cinematográfico: \\
\hline & $\begin{array}{l}\text { Você refere que o item "orientação para resultados" pode entrar junto com o item "visão dos produtos } \\
\text { ornalísticos". A descrição original era a seguinte: "Visão dos produtos jornalísticos - entrega material } \\
\text { inematográfico adequado para exibição em qualquer produto jornalístico da televisão, tanto do ponto de } \\
\text { ista técnico quanto editorial", e "Orientação para resultados - entrega o material cinematográfico dentro dos } \\
\text { razos estabelecidos e sem prejuízo da qualidade técnica". 2) Você pede também para "explicar melhor o } \\
\text { fue seriam esses produtos". } \\
\text { Jeja a alteração: } \\
\text { ) Alterei o nome do item para "Cumprimento de metas e resultados" e juntei num item só. Expliquei } \\
\text { produto", com o parêntese: "diferentes jornais e programas da emissora". } \\
\text { "Cumprimento de metas e resultados - entrega o material cinematográfico dentro dos prazos estabelecidos, } \\
\text { em prejuízo da qualidade técnica e com adequação editorial aos produtos (diferentes jornais ou programas } \\
\text { la emissora)". }\end{array}$ \\
\hline & que acha ? Ficou mais claro e compreensível agora? SIM \\
\hline & Comentários: \\
\hline & Na planilha de repórter: \\
\hline & $\begin{array}{l}\text { Você se refere no item tecnologia, "acho que precisava diferenciar equipamentos de uso externo (como kit } \\
\text { orrespondente, por exemplo) e outros recursos (como computadores e ilhas não lineares). Isso porque } \\
\text { lguns recursos são de uso diário e outros, não". } \\
\text { Jeja a alteração: } \\
\text { Deixei apenas "conhecimentos de informática e edição não linear", e exclui o kit correspondente, pra ficar } \\
\text { nais enxuto. Ficará assim: Tecnologia (informática e edição não linear). }\end{array}$ \\
\hline & que acha ? Ficou mais claro e compreensível agora? SIM \\
\hline & Comentários: \\
\hline & $\begin{array}{l}\text { "Você pede também para "explicar melhor que tipos de produtos" e escreve "acho que esse item } \\
\text { orientação para resultados) está parecido com o item "visão dos produtos jornalísticos". } \\
\text { Jeja a alteração: } \\
\text { 'ara explicar tipos de produtos, acho que um parêntese com o seguinte texto resolve: "(os diferentes jornais e } \\
\text { rogramas da emissora)". } \\
\text { Quanto ao item "orientação para resultados" e "visão dos produtos jornalísticos", alterei o nome do item para } \\
\text { Cumprimento de metas e resultados", e juntei num item só. Mudei a palavra "produto" para "diferentes } \\
\text { ornais e programas da emissora". } \\
\text { "Cumprimento de metas e resultados - entrega reportagens dentro dos prazos estabelecidos, para exibição } \\
\text { m qualquer produto jornalístico da televisão (diferentes jornais e programas da emissora), tanto do ponto de } \\
\text { ista técnico quanto editorial". "Tem foco na notícia e consegue adequar o texto à imagem". } \\
\text { Oque acha ? Ficou mais claro e compreensível agora? SIM }\end{array}$ \\
\hline & \\
\hline
\end{tabular}




\section{ANEXO 5-A \\ DEFINIÇÃO DO PADRÃO DE DESEMPENHO DA EMPRESA - R}

\begin{tabular}{|c|c|c|c|}
\hline \multicolumn{4}{|c|}{ Validação do Perfil Esperado pela Empresa - Repórter } \\
\hline $\begin{array}{l}\text { Habilidades e } \\
\text { Competência Técnica }\end{array}$ & chefia 1 & chefia 2 & MÉDIA \\
\hline Formação acadêmica & 2 & 2 & 2 \\
\hline Experiência & 3 & 1 & 2 \\
\hline \multicolumn{4}{|l|}{ Conhecimentos } \\
\hline $\begin{array}{l}\text { Língua portuguesa escrita e } \\
\text { falada }\end{array}$ & 3 & 3 & 3 \\
\hline Idioma inglês falado & 2 & 2 & 2 \\
\hline $\begin{array}{l}\text { Técnica de expressão no } \\
\text { vídeo (uso da voz, } \\
\text { naturalidade no vídeo e } \\
\text { adequado uso dos } \\
\text { equipamentos) }\end{array}$ & 2 & 3 & 2,5 \\
\hline Fontes & 2 & 3 & 2,5 \\
\hline $\begin{array}{l}\text { Produção de reportagem e } \\
\text { edição }\end{array}$ & 2 & 2 & 2 \\
\hline $\begin{array}{l}\text { Tecnologia (informática e } \\
\text { edição não linear) }\end{array}$ & 1 & 1 & 1 \\
\hline Desempenho & chefia 1 & chefia 2 & MÉDIA \\
\hline $\begin{array}{l}\text { 1- Visão do } \\
\text { processo }\end{array}$ & 2 & 2 & 2 \\
\hline $\begin{array}{l}\text { 2- Cumprimento de metas e } \\
\text { resultados }\end{array}$ & 3 & 3 & 3 \\
\hline 3- Trabalho em equipe & 3 & 3 & 3 \\
\hline 4 - Inovação & 2 & 1 & 1,5 \\
\hline $\begin{array}{l}\text { 5- Comprometimento } \\
\text { Profissional }\end{array}$ & 3 & 2 & 2,5 \\
\hline 6- Qualidade de Texto & 3 & 3 & 3 \\
\hline 7- Planejamento e Análise & 2 & 3 & 2,5 \\
\hline $\begin{array}{l}\text { 8- Comunicação e Imagem } \\
\text { no Vídeo }\end{array}$ & 3 & 3 & 3 \\
\hline $\begin{array}{l}\text { 9- Atualização } \\
\text { Profissional }\end{array}$ & 2 & 3 & 2,5 \\
\hline
\end{tabular}

\begin{tabular}{|l|}
\hline Critérios de importância: \\
\hline 0 - não é importante \\
\hline $1-$ menos importante \\
\hline $2-$ importante \\
\hline $3-$ muito importante \\
\hline
\end{tabular}


ANEXO 5-B

DEFINIÇÃO DO PADRÃO DE DESEMPENHO DA EMPRESA - RC

\begin{tabular}{|c|c|c|c|}
\hline \multicolumn{4}{|c|}{ Validação do Perfil Esperado pela Empresa - Rep.Cinematog } \\
\hline $\begin{array}{l}\text { Habilidades e } \\
\text { Competência Técnica }\end{array}$ & chefia 1 & Chefia 2 & MÉDIA \\
\hline Formação acadêmica & 2 & 2 & 2 \\
\hline Experiência & 3 & 2 & 2,5 \\
\hline \multicolumn{4}{|l|}{ Conhecimentos } \\
\hline $\begin{array}{l}\text { - Uso de equipamentos } \\
\text { (câmera e complementos: } \\
\text { tripé, filtros, captação de } \\
\text { áudio, microfone) }\end{array}$ & 3 & 3 & 3 \\
\hline $\begin{array}{l}\text { - Técnicas de iluminação, } \\
\text { enquadramento, planos e } \\
\text { fotografia }\end{array}$ & 3 & 3 & 3 \\
\hline $\begin{array}{l}\text { - Técnicas de narrativa } \\
\text { visual (planejamento, } \\
\text { roteiro, percepção da } \\
\text { notícia e texto) }\end{array}$ & 2 & 2 & 2 \\
\hline - Kit correspondente & 1 & 1 & 1 \\
\hline - Edição de Imagem & 2 & 2 & 2 \\
\hline - Idioma inglês falado & 1 & 1 & 1 \\
\hline Desempenho & chefia 1 & Chefia 2 & MÉDIA \\
\hline 1- Visão do processo & 2 & 2 & 2 \\
\hline $\begin{array}{l}\text { 2- Cumprimento de metas e } \\
\text { resultados }\end{array}$ & 2 & 3 & 2,5 \\
\hline 3- Trabalho em equipe & 3 & 3 & 3 \\
\hline 4 - Inovação & 2 & 2 & 2 \\
\hline 5- Senso de oportunidade & 2 & 2 & 2 \\
\hline 6- Participação jornalística & 2 & 3 & 2,5 \\
\hline 7- Comprometimento & 2 & 3 & 2,5 \\
\hline 8- Atualização profissional & 3 & 3 & 3 \\
\hline
\end{tabular}

\begin{tabular}{|l|}
\hline Critérios de importância: \\
\hline $0-$ não é importante \\
\hline $1-$ menos importante \\
\hline $2-$ importante \\
\hline $3-$ muito importante \\
\hline
\end{tabular}




\section{ANEXO 6 TERMO DE CONSENTIMENTO INFORMADO}

Título da Pesquisa: "Estudo da manifestação do stress em profissionais do telejornalismo e sua correlação com o desempenho profissional".

Nome da Pesquisadora: Sonia Maria Minelli Senese, psicóloga, CRP 06/10.104; mestranda do Departamento de Psicologia Social do Instituto de Psicologia da Universidade de São Paulo; e-mail: sonia.senese@ig.com.br; tel: (11) 3864-7854 e (11) 9121-9121.

Nome do Orientador: Prof. Dr. Esdras Guerreiro Vasconcellos, psicólogo, professor de pós-graduação do Instituto de Psicologia da Universidade de São Paulo, e-mail: esdras@usp.com.br ou interciências@uol.com.br

Informações sobre a participação: Você está sendo convidado (a) a participar de uma pesquisa de mestrado. É muito importante que você compreenda todos os princípios desta pesquisa:

(a) você só participa se desejar;

(b) você pode deixar de participar a qualquer momento, sem sofrer qualquer tipo de retaliação por causa disto;

(c) você poderá, a qualquer momento, entrar em contato com a pesquisadora para tirar qualquer dúvida que tiver a respeito desta pesquisa;

(d) sua identidade não será revelada pela pesquisadora durante ou após a pesquisa.

Introdução: É fato que as empresas para fazer frente às necessidades do mercado cada vez mais competitivas, buscam manter em seu quadro de pessoal, profissionais qualificados e que conseguem desempenhar-se. $\mathrm{O}$ desempenho está atrelado ao alcance dos resultados, às ações, atitudes e habilidades direcionadas à consecução dos objetivos esperados pela empresa e, para que o profissional consiga esse intento, precisa lidar cotidianamente com situações adversas que demandam enfrentamento. Segundo os estudiosos Lazarus \& Folkman (1984), essas circunstâncias podem ser geradoras de stress, pois os recursos disponíveis da pessoa poderão estar aquém das demandas do ambiente.

Focaremos nessa pesquisa, dois grupos de profissionais que atuam em parceria no dia-a-dia do telejornalismo: o repórter e o repórter cinematográfico. O repórter cinematográfico é o profissional que capta as imagens, que está atento a todos os estímulos externos e que tem a sensibilidade para os fatos instantâneos, o olho dele é a câmera. O repórter é o que está sempre bem informado e preparado para ir ao encontro dos fatos e levar a notícia às pessoas. Ambos vivenciam cotidianamente fontes geradoras de stress seja negativo ou positivo. Stress negativo, se considerarmos fatores ligados à imprevisibilidade do local da gravação e entrevistados, a urgência de tempo, as cobranças pela precisão e qualidade das imagens e reportagens, entre outras. E stress positivo se levarmos em conta que o trabalho lhes possibilita o prazer de ver a imagem captada, a matéria no ar e a possibilidade de, ao levar a notícia, ter o sentimento de compromisso cumprido com a comunidade e com as pessoas.

Objetivos do estudo: A presente pesquisa tem o objetivo principal verificar de que maneira o stress se manifesta em profissionais de telejornalismo, especificamente repórter e repórter cinematográfico, e analisá-lo em correlação com o nível de desempenho profissional.

Procedimentos: Caso concorde em participar desta pesquisa, a mesma envolverá três partes :

1) preencher um formulário com dados pessoais, 
2) responder a dois testes de avaliação de stress (BEPATYA e LSS/VAS)

3)participar do processo de avaliação de desempenho com suas chefias imediatas, que compreende:

.. você irá receber informação sobre o processo e procedimentos da avaliação de desempenho;

.. você deverá fazer sua auto-avaliação, devendo preencher instrumento específico;

.. suas duas chefias imediatas o avaliará e preencherão o instrumento específico;

.. haverá uma reunião de avaliação em que participarão você e suas duas chefias, sobre o feedback de desempenho;

Duração do estudo: aproximadamente 2 horas e 30', compreendendo formulário, testes e reunião de avaliação.

Risco: é considerado um estudo de risco mínimo.

Sigilo: Sua identidade não será revelada. Ao invés do seu nome, constará nos questionários um código numérico de identificação. Uma ficha com seus dados pessoais será guardada separadamente em local seguro.

Número de voluntários: 30 a 40 voluntários.

Se você não entendeu alguma parte deste documento, solicite explicações à pesquisadora. Somente assine abaixo, após a completa compreensão do estudo.

\section{Termo de Consentimento}

$\mathrm{Eu}$ , em pleno gozo de minhas faculdades

mentais, com idade superior a 18 anos, faço-me voluntário para participar desta pesquisa. Os objetivos, a natureza, a duração e os procedimentos de pesquisa foram a mim esclarecidos pela pesquisadora Sonia Maria Minelli Senese. Concedo à mesma pesquisadora permissão para o uso dos meus dados obtidos através desta pesquisa para fins de publicação desde que a minha identidade seja mantida em sigilo. Sei que a qualquer momento posso deixar de participar de participar e não sofrer qualquer dano.

Assinatura do voluntário (a) :

Local e data:

Nome completo:

Eu assisti aos esclarecimentos sobre a pesquisa descritos acima, atestando que foi dado à voluntária (o) o direito de formular perguntas e testemunhei a assinatura deste documento pelo voluntário. Assinatura da testemunha:

Nome completo:

Assinatura da pesquisadora :

Nome completo:

Este documento em duas vias - uma para o voluntário (a) e outra para a pesquisadora.

\section{AGRADECEMOS ANTECIPADAMENTE SUA COLABORAÇÃO NESTA PESQUISA.}




\section{ANEXO 7 \\ MATRIZ GERAL DE INTERCORRELAÇÃO DO GRUPO R}

\begin{tabular}{|c|c|c|c|c|c|c|c|c|c|c|c|c|c|c|}
\hline & Sexo & Idade & E. Civil & $\begin{array}{l}\text { № } \\
\text { filhos }\end{array}$ & Escol. & $\begin{array}{c}\text { Tpo } \\
\text { Empresa }\end{array}$ & $\begin{array}{c}\text { Tpo } \\
\text { Profissao }\end{array}$ & $\begin{array}{c}\text { № } \\
\text { horas }\end{array}$ & $\begin{array}{c}\% \\
\text { Presença }\end{array}$ & $\begin{array}{l}\text { Média de } \\
\text { frequência }\end{array}$ & $\begin{array}{l}\text { Média de } \\
\text { Intensidade }\end{array}$ & Competência & Desempenho & $\begin{array}{l}\text { Total - } \\
\text { NBTA }\end{array}$ \\
\hline Sexo & & $\begin{array}{l}t \\
=2,241 \\
p \\
=0,041\end{array}$ & $\begin{array}{l}\varphi=- \\
0,174 \\
p=0,436\end{array}$ & $\begin{array}{l}t=1,541 \\
p \\
=0,142\end{array}$ & * & $\begin{array}{l}t=1,063 \\
p=0,302\end{array}$ & $\begin{array}{l}t=2,039 \\
p=0,061\end{array}$ & $\begin{array}{l}t=- \\
0,305 \\
p \\
=0,764\end{array}$ & $\begin{array}{l}t=-0,994 \\
p=0,338\end{array}$ & $\begin{array}{l}t=-1,598 \\
p=0,127\end{array}$ & $\begin{array}{l}t=-1,391 \\
p=0,181\end{array}$ & $\begin{array}{l}t=1,581 \\
p=0,131\end{array}$ & $\begin{array}{l}t=2,988 \quad p \\
=0,008\end{array}$ & $\begin{array}{l}t=- \\
0,966 \\
p \\
=0,347\end{array}$ \\
\hline Idade & & & $\begin{array}{l}t=- \\
1,693 \\
p=0,108\end{array}$ & $\begin{array}{l}r=0, \\
789 \\
p=0,000\end{array}$ & * & $\begin{array}{l}r=0,505 \\
p= \\
0,023\end{array}$ & $\begin{array}{l}r=0,952 \\
p=0,000\end{array}$ & $\begin{array}{l}r= \\
0,334 \\
p=0,149\end{array}$ & $\begin{array}{l}r=-0,291 \\
p=0,213\end{array}$ & $\begin{array}{l}r=-0,264 \\
p=0,261\end{array}$ & $\begin{array}{l}r=-0,203 \\
p=0,391\end{array}$ & $\begin{array}{l}r=0,580 \\
p=0,007\end{array}$ & $\begin{array}{l}r=0,591 \\
p=0,006\end{array}$ & $\begin{array}{l}r= \\
0,136 \\
p=0,568\end{array}$ \\
\hline Estado Civil & & & & $\begin{array}{l}t=- \\
4,000 \\
p=0,001\end{array}$ & * & $\begin{array}{l}t=-1,287 \\
p=0,214\end{array}$ & $\begin{array}{l}t=-1,780 \\
p=0,092\end{array}$ & $\begin{array}{l}t=0,000 \\
p=1,000\end{array}$ & $\begin{array}{l}t=-0,076 \\
p=0,940\end{array}$ & $\begin{array}{l}t=0,224 \\
p=0,825\end{array}$ & $\begin{array}{l}t=0,085 \\
p=0,933\end{array}$ & $\begin{array}{l}t=-1,816 \\
p=0,086\end{array}$ & $\begin{array}{l}t=-1,195 \\
p=0,248\end{array}$ & $\begin{array}{l}t=- \\
0,578 \\
p=0,570\end{array}$ \\
\hline № filhos & & & & & * & $\begin{array}{l}r=0,699 \\
p= \\
0,001\end{array}$ & $\begin{array}{l}r=0,846 \\
p=0,000\end{array}$ & $\begin{array}{l}r= \\
0,145 \\
p=0,541\end{array}$ & $\begin{array}{l}r=-0,174 \\
p=0,464\end{array}$ & $\begin{array}{l}r=-0,031 \\
p=0,896\end{array}$ & $\begin{array}{l}r=-0,126 \\
p=0,597\end{array}$ & $\begin{array}{l}r=0,682 \\
p=0,001\end{array}$ & $\begin{array}{l}r=0,652 \\
p=\quad 0,002\end{array}$ & $\begin{array}{l}r= \\
0,128 \\
p=0,590\end{array}$ \\
\hline Escolaridade & & & & & & * & * & * & * & * & * & * & * & * \\
\hline $\begin{array}{l}\text { Tempo } \\
\text { Empresa }\end{array}$ & & & & & & & $\begin{array}{l}r=0,561 \\
p=0,010\end{array}$ & $\begin{array}{l}r=- \\
0,062 \\
p=0,795\end{array}$ & $\begin{array}{l}r=-0,190 \\
p=0,423\end{array}$ & $\begin{array}{l}r=0,047 \\
p=0,844\end{array}$ & $\begin{array}{l}r=0,246 \\
p=0,295\end{array}$ & $\begin{array}{l}r=0,739 \\
p=\quad 0,000\end{array}$ & $\begin{array}{l}r=0,685 \\
p=\quad 0,001\end{array}$ & $\begin{array}{l}r= \\
0,137 \\
p=0,585\end{array}$ \\
\hline $\begin{array}{l}\text { Tempo } \\
\text { Profissao }\end{array}$ & & & & & & & & $\begin{array}{l}r= \\
0,330 \\
p=0,156\end{array}$ & $\begin{array}{l}r=-0,183 \\
p=0,440\end{array}$ & $\begin{array}{l}r=-0,168 \\
p=0,478\end{array}$ & $\begin{array}{l}r=-0,186 \\
p=0,433\end{array}$ & $\begin{array}{l}r=0,592 \\
p=0,006\end{array}$ & $\begin{array}{l}r=0,606 \\
p=0,005\end{array}$ & $\begin{array}{l}r= \\
0,188 \\
p=0,429\end{array}$ \\
\hline № horas & & & & & & & & & $\begin{array}{l}r=0,224 \\
p=0,342\end{array}$ & $\begin{array}{l}r=0,163 \\
p=0,492\end{array}$ & $\begin{array}{l}r=0,144 \\
p=0,545\end{array}$ & $\begin{array}{l}r=0,062 \\
p=0,794\end{array}$ & $\begin{array}{l}r=0,098 \\
p=0,680\end{array}$ & $\begin{array}{l}r= \\
0,239 \\
p=0,310\end{array}$ \\
\hline \% Presença & & & & & & & & & & $\begin{array}{l}r=0,503 \\
p=0,024\end{array}$ & $\begin{array}{l}r=0,205 \\
p=0,386\end{array}$ & $\begin{array}{l}r=-0,273 \\
p=0,244\end{array}$ & $\begin{array}{l}r=-0,199 \\
p=0,399\end{array}$ & $\begin{array}{l}r= \\
0,393 \\
p=0,087\end{array}$ \\
\hline $\begin{array}{l}\text { Média de } \\
\text { frequência }\end{array}$ & & & & & & & & & & & $\begin{array}{l}r=0,515 \\
p=0,020\end{array}$ & $\begin{array}{l}r=0,089 \\
p=0,710\end{array}$ & $\begin{array}{l}r=0,000 \\
p=1,000\end{array}$ & $\begin{array}{l}r= \\
0,469 \\
p=0,037\end{array}$ \\
\hline $\begin{array}{l}\text { Média de } \\
\text { Intensidade }\end{array}$ & & & & & & & & & & & & $\begin{array}{l}r=0,171 \\
p=0,472\end{array}$ & $\begin{array}{l}r=0,053 \\
p=0,823\end{array}$ & $\begin{array}{l}r= \\
0,302 \\
p=0,195\end{array}$ \\
\hline Competência & & & & & & & & & & & & & $\begin{array}{l}r=0,864 \\
p=0,000\end{array}$ & $\begin{array}{l}r= \\
0,093 \\
p=0,697\end{array}$ \\
\hline Desempenho & & & & & & & & & & & & & & \begin{tabular}{|l|}
$r=$ \\
0,111 \\
$p=0,642$
\end{tabular} \\
\hline Total - NBTA & & & & & & & & & & & & & & \\
\hline
\end{tabular}

* todos apresentam escolaridade superior ou pós-graduação. 


\begin{tabular}{|c|c|c|c|c|c|c|c|c|c|c|c|c|c|c|}
\hline & Sexo & Idade & E. Civil & $\begin{array}{c}\text { № } \\
\text { filhos }\end{array}$ & Escol. & $\begin{array}{c}\text { Tpo } \\
\text { Empresa }\end{array}$ & $\begin{array}{c}\text { Tpo } \\
\text { Profissao }\end{array}$ & $\begin{array}{c}\text { № } \\
\text { horas }\end{array}$ & $\begin{array}{c}\% \\
\text { Presença }\end{array}$ & $\begin{array}{l}\text { Média de } \\
\text { frequência }\end{array}$ & $\begin{array}{c}\text { Média de } \\
\text { Intensidade }\end{array}$ & Competência & Desempenho & $\begin{array}{l}\text { Total - } \\
\text { NBTA }\end{array}$ \\
\hline Sexo & & $\begin{array}{l}t \\
=1,709 \\
p \\
=0,105\end{array}$ & $\begin{array}{l}\varphi=- \\
0,140 \\
p=0,531\end{array}$ & $\begin{array}{l}t=2,046 \\
p= \\
0,057\end{array}$ & $\begin{array}{l}\varphi=- \\
0,145 \\
p=0,515\end{array}$ & $\begin{array}{l}t=1,743 \\
p=0,194\end{array}$ & $\begin{array}{l}t=1,203 \\
p=0,245\end{array}$ & $\begin{array}{l}t=-0,577 \\
p=0,572\end{array}$ & $\begin{array}{l}t=-0,229 \\
p=0,822\end{array}$ & $\begin{array}{l}t=0,281 \\
p=0,782\end{array}$ & $\begin{array}{l}t=-1,181 \\
p=0,253\end{array}$ & $\begin{array}{l}t=-0,224 \\
p=0,825\end{array}$ & $\begin{array}{l}t=-0,449 \\
p=0,659\end{array}$ & $\begin{array}{l}t=- \\
2,263 \\
p=0,795\end{array}$ \\
\hline Idade & & & $\begin{array}{l}t=- \\
1,069 \\
p \\
=0,299\end{array}$ & $\begin{array}{l}r= \\
0,513 \\
p=0,021\end{array}$ & $\begin{array}{l}t= \\
1,000 \\
p= \\
0,331\end{array}$ & $\begin{array}{l}r=0,760 \\
p=0,000\end{array}$ & $\begin{array}{l}r=0,865 \\
p=0,000\end{array}$ & $\begin{array}{l}r=- \\
0,538 \\
p=0,018\end{array}$ & $\begin{array}{l}r=0,371 \\
p=0,107\end{array}$ & $\begin{array}{l}r=0,108 \\
p=0,651\end{array}$ & $\begin{array}{l}r=0,126 \quad p \\
=0,595\end{array}$ & $\begin{array}{l}r=-0,191 \\
p=0,421\end{array}$ & $\begin{array}{l}r=-0,154 \\
p=0,517\end{array}$ & $\begin{array}{l}r \\
=0,382 \\
p=0,096\end{array}$ \\
\hline Estado Civil & & & & $\begin{array}{l}t=- \\
9,675 \\
p \\
=0,000\end{array}$ & $\begin{array}{l}\varphi=- \\
0,275 \\
p=0,219\end{array}$ & $\begin{array}{l}t=- \\
1,121 \\
p=0,310\end{array}$ & $\begin{array}{l}t=-0,398 \\
p=0,696\end{array}$ & $\begin{array}{l}t=0,733 \\
p \\
=0,474\end{array}$ & $\begin{array}{l}t=1,258 \\
p=0,225\end{array}$ & $\begin{array}{l}t=0,355 \\
p=0,727\end{array}$ & $\begin{array}{l}t=0,368 \\
p=0,717\end{array}$ & $\begin{array}{l}t=-0,121 \\
p=0,905\end{array}$ & $\begin{array}{l}t=-0,231 \\
p=0,820\end{array}$ & $\begin{array}{l}t=- \\
0,486 \\
p \\
=0,633\end{array}$ \\
\hline № filhos & & & & & $\begin{array}{l}t=- \\
0,408 \\
p= \\
0,688\end{array}$ & $\begin{array}{l}r=0,539 \\
p= \\
0,014\end{array}$ & $\begin{array}{l}r=0,325 \\
p=0,162\end{array}$ & $\begin{array}{l}r=- \\
0,177 \\
p=0,469\end{array}$ & $\begin{array}{l}r=-0,124 \\
p=0,604\end{array}$ & $\begin{array}{l}r=-0,069 \\
p=0,772\end{array}$ & $\begin{array}{l}r=-0,057 \quad p \\
=0,813\end{array}$ & $\begin{array}{l}r=-0,215 \\
p=0,362\end{array}$ & $\begin{array}{l}r=-0,192 \\
p=0,418\end{array}$ & $\begin{array}{l}r \\
=0,297 \\
p=0,096\end{array}$ \\
\hline Escolaridade & & & & & & $\begin{array}{l}t=1,010 \\
p=0,326\end{array}$ & $\begin{array}{l}t=0,994 \\
p=0,333\end{array}$ & $\begin{array}{l}t=2,513 \\
p= \\
0,027\end{array}$ & $\begin{array}{l}t=0,640 \\
p=0,530\end{array}$ & $\begin{array}{l}t=0,184 \\
p=0,856\end{array}$ & $\begin{array}{l}t=1,404 \\
p=0,177\end{array}$ & $\begin{array}{l}t=-1,102 \\
p=0,285\end{array}$ & $\begin{array}{l}t=-0,429 \\
p=0,673\end{array}$ & $\begin{array}{l}t=- \\
0,904 \\
p= \\
0,378\end{array}$ \\
\hline $\begin{array}{l}\text { Tempo } \\
\text { Empresa }\end{array}$ & & & & & & & $\begin{array}{l}r=0,721 \\
p=0,000\end{array}$ & $\begin{array}{l}r=- \\
0,348 \\
p= \\
0,144\end{array}$ & $\begin{array}{l}r=0,479 \\
p=0,033\end{array}$ & $\begin{array}{l}r=-0,123 \\
p=0,605\end{array}$ & $\begin{array}{l}r=-0,047 \quad p \\
=0,845\end{array}$ & $\begin{array}{l}r=-0,081 \\
p=0,735\end{array}$ & $\begin{array}{l}r=-0,071 \\
p=0,767\end{array}$ & $\begin{array}{l}r= \\
0,568 \\
p= \\
0,009\end{array}$ \\
\hline $\begin{array}{l}\text { Tempo } \\
\text { Profissao }\end{array}$ & & & & & & & & $\begin{array}{l}r=- \\
0,373 \\
p= \\
0,144\end{array}$ & $\begin{array}{l}r=-0,369 \\
p=0,110\end{array}$ & $\begin{array}{l}r=0,094 \\
p=0,695\end{array}$ & $\begin{array}{l}r=0,147 \quad p \\
=0,537\end{array}$ & $\begin{array}{l}r=0,052 \\
p=0,827\end{array}$ & $\begin{array}{l}r=0,058 \\
p=0,809\end{array}$ & $\begin{array}{l}r \\
=0,301 \\
p=0,198\end{array}$ \\
\hline № horas & & & & & & & & & $\begin{array}{l}r=-0,404 \\
p=0,087\end{array}$ & $\begin{array}{l}r=-0,204 \\
p=0,401\end{array}$ & $\begin{array}{l}r=-0,001 \quad p \\
=0,996\end{array}$ & $\begin{array}{l}r=-0,212 \\
p=0,383\end{array}$ & $\begin{array}{l}r=-0,098 \\
p=0,690\end{array}$ & $\begin{array}{l}r=- \\
0,466 \\
p= \\
0,044\end{array}$ \\
\hline$\%$ Presença & & & & & & & & & & $\begin{array}{l}r=0,553 \\
p=0,011\end{array}$ & $\begin{array}{l}r=0,575 \\
p=0,008\end{array}$ & $\begin{array}{l}r=-0,049 \\
p=0,838\end{array}$ & $\begin{array}{l}r=0,070 \\
p=0,769\end{array}$ & $\begin{array}{l}r= \\
0,414 \\
p= \\
0,070\end{array}$ \\
\hline $\begin{array}{l}\text { Média de } \\
\text { frequência }\end{array}$ & & & & & & & & & & & $\begin{array}{l}r=0,790 \\
p=0,000\end{array}$ & $\begin{array}{l}r=-0,166 \\
p=0,485\end{array}$ & $\begin{array}{l}r=-0,034 \\
p=0,888\end{array}$ & $\begin{array}{l}r=- \\
0,002 \\
p= \\
0,994\end{array}$ \\
\hline $\begin{array}{l}\text { Média de } \\
\text { Intensidade }\end{array}$ & & & & & & & & & & & & $\begin{array}{l}r=-0,256 \\
p=0,277\end{array}$ & $\begin{array}{l}r=-0,033 \\
p=0,891\end{array}$ & $\begin{array}{l}r=- \\
0,042 p \\
=0,860\end{array}$ \\
\hline $\begin{array}{l}\text { Competência } \\
\text { consensual } \\
\text { Média }\end{array}$ & & & & & & & & & & & & & $\begin{array}{l}r=0,827 \\
p=0,000\end{array}$ & $\begin{array}{l}r \\
=0,223 \\
p= \\
0,344\end{array}$ \\
\hline $\begin{array}{l}\text { Desempenho } \\
\text { consensual } \\
\text { Média }\end{array}$ & & & & & & & & & & & & & & $\begin{array}{l}r= \\
0,314 \\
p=0,178\end{array}$ \\
\hline Total - NBTA & & & & & & & & & & & & & & \\
\hline
\end{tabular}


ANEXO 10

MATRIZ GERAL DE INTERCORRELAÇÃO DA AT

\begin{tabular}{|c|c|c|c|c|c|c|c|c|c|c|c|c|c|c|}
\hline & Sexo & Idade & E. Civil & $\begin{array}{l}\text { № } \\
\text { filhos }\end{array}$ & Escol. & $\begin{array}{c}\text { Tpo } \\
\text { Empresa }\end{array}$ & $\begin{array}{c}\text { Tpo } \\
\text { Profissao }\end{array}$ & $\begin{array}{c}\text { № } \\
\text { horas }\end{array}$ & $\begin{array}{c}\% \\
\text { Presença }\end{array}$ & $\begin{array}{c}\text { Média de } \\
\text { frequência }\end{array}$ & $\begin{array}{c}\text { Média de } \\
\text { Intensidade }\end{array}$ & Competência & Desempenho & $\begin{array}{l}\text { Total - } \\
\text { NBTA }\end{array}$ \\
\hline Sexo & & $\begin{array}{l}\mathrm{t}= \\
4,115 \\
\mathrm{p}= \\
0,000\end{array}$ & $\begin{array}{l}\varphi=- \\
0,112 \\
p=0,479\end{array}$ & $\begin{array}{l}t= \\
2,744 \\
p= \\
0,011\end{array}$ & $\begin{array}{l}\varphi=0,335 \\
p=0,034\end{array}$ & $\begin{array}{l}t=2,792 \\
p=0,008\end{array}$ & $\begin{array}{l}t=3,556 \\
p=0,001\end{array}$ & $\begin{array}{l}t=- \\
1,659 \\
p= \\
0,106\end{array}$ & $\begin{array}{l}t=- \\
1,562 \\
p=0,127\end{array}$ & $\begin{array}{l}t=-1,20 \\
p=0,237\end{array}$ & $\begin{array}{l}t=-2,668 \\
p=0,011\end{array}$ & $\begin{array}{l}t=0,586 \\
p=0,562\end{array}$ & $\begin{array}{l}t=2,646 \\
p=0,012\end{array}$ & $\begin{array}{l}t=- \\
1,238 \\
p= \\
0,223\end{array}$ \\
\hline Idade & & & $\begin{array}{l}t=- \\
2,174 \\
p= \\
0,036\end{array}$ & $\begin{array}{l}r= \\
0,685 \\
p=0,000\end{array}$ & $\begin{array}{l}\mathrm{t}= \\
1,743 \\
\mathrm{p}= \\
0,089\end{array}$ & $\begin{array}{l}r=0,653 \\
p=0,000\end{array}$ & $\begin{array}{l}r=0,916 \\
p=0,000\end{array}$ & $\begin{array}{l}r=- \\
0,160 \\
p=0,332\end{array}$ & $\begin{array}{l}r=0,009 \\
p=0,958\end{array}$ & $\begin{array}{l}r=-0,081 \\
p=0,620\end{array}$ & $\begin{array}{l}r=-0,128 \\
p=0,421\end{array}$ & $\begin{array}{l}r=0,102 \\
p=0,530\end{array}$ & $\begin{array}{l}r=-0,287 \\
p=0,072\end{array}$ & $\begin{array}{l}r=- \\
0,214 \\
p=0,184\end{array}$ \\
\hline Estado Civil & & & & $\begin{array}{l}t=- \\
5,576 \\
p= \\
0,000\end{array}$ & $\begin{array}{l}\varphi=- \\
0,026 \\
p=0,868\end{array}$ & $\begin{array}{l}t=-1,398 \\
p=0,170\end{array}$ & $\begin{array}{l}t=-1,775 \\
p= \\
0,0,084\end{array}$ & $\begin{array}{l}t=0,738 \\
p= \\
0,465\end{array}$ & $\begin{array}{l}t=0,832 \\
p=0,411\end{array}$ & $\begin{array}{l}t=0,537 \\
p=0,594\end{array}$ & $\begin{array}{l}t=0,592 \\
p=0,557\end{array}$ & $\begin{array}{l}t=-1,069 \\
p=0,292\end{array}$ & $\begin{array}{l}t=-1,274 \\
p=0,211\end{array}$ & $\begin{array}{l}t=- \\
0,659 \\
p= \\
0,514\end{array}$ \\
\hline № filhos & & & & & $\begin{array}{l}\mathrm{t}= \\
1,223 \\
\mathrm{p}= \\
0,229\end{array}$ & $\begin{array}{l}r=0,595 \\
p= \\
0,000\end{array}$ & $\begin{array}{l}r=0,633 \\
p=0,000\end{array}$ & $\begin{array}{l}r=- \\
0,140 \\
p=0,394\end{array}$ & $\begin{array}{l}r=-0,066 \\
p=0,958\end{array}$ & $\begin{array}{l}r=-0,030 \\
p=0,855\end{array}$ & $\begin{array}{l}r=-0,158 \\
p=0,331\end{array}$ & $\begin{array}{l}r=-0,131 \\
p=0,421\end{array}$ & $\begin{array}{l}r=0,332 \\
p=0,037\end{array}$ & $\begin{array}{l}r \\
=0,152 \\
p=0,348\end{array}$ \\
\hline Escolaridade & & & & & & $\begin{array}{l}t=2,152 \\
p= \\
0,045\end{array}$ & $\begin{array}{l}t=1,718 \\
p=0,094\end{array}$ & $\begin{array}{l}\mathrm{t}=- \\
1,268 \\
\mathrm{p}= \\
0,213\end{array}$ & $\begin{array}{l}t=-0,082 \\
p=0,935\end{array}$ & $\begin{array}{l}t=-0,640 \\
p=0,526\end{array}$ & $\begin{array}{l}t=-0,955 \\
p=0,346\end{array}$ & $\begin{array}{l}t=-1,619 \\
p=0,114\end{array}$ & $\begin{array}{l}t=1,077 \\
p=0,288\end{array}$ & $\begin{array}{l}t=- \\
1,237 \\
p= \\
0,224\end{array}$ \\
\hline $\begin{array}{l}\text { Tempo } \\
\text { Empresa }\end{array}$ & & & & & & & $\begin{array}{l}r=0,648 \\
p=0,000\end{array}$ & $\begin{array}{l}r=- \\
0,341 \\
p= \\
0,034\end{array}$ & $\begin{array}{l}r=-0,200 \\
p=0,216\end{array}$ & $\begin{array}{l}r=-0,133 \\
p=0,414\end{array}$ & $\begin{array}{l}r=-0,092 \\
p=0,573\end{array}$ & $\begin{array}{l}r=0,082 \\
p=0,617\end{array}$ & $\begin{array}{l}r=-0,251 \\
p=0,119\end{array}$ & $\begin{array}{l}r= \\
0,331 \\
p= \\
0,037\end{array}$ \\
\hline $\begin{array}{l}\text { Tempo } \\
\text { Profissao }\end{array}$ & & & & & & & & $\begin{array}{l}r=- \\
0,111 \\
p= \\
0,502\end{array}$ & $\begin{array}{l}r=0,062 \\
p=0,702\end{array}$ & $\begin{array}{l}r=-0,051 \\
p=0,755\end{array}$ & $\begin{array}{l}r=-0,109 \\
p=0,505\end{array}$ & $\begin{array}{l}r=0,240 \\
p=0,135\end{array}$ & $\begin{array}{l}r=0,386 \\
p=0,014\end{array}$ & $\begin{array}{l}r \\
=0,204 \\
p=0,207\end{array}$ \\
\hline № horas & & & & & & & & & $\begin{array}{l}r=-0,008 \\
p=0,962\end{array}$ & $\begin{array}{l}r=0,034 \\
p=0,835\end{array}$ & $\begin{array}{l}r=-0,249 \\
p=0,126\end{array}$ & $\begin{array}{l}r=-0,047 \\
p=0,775\end{array}$ & $\begin{array}{l}r=-0,147 \\
p=0,372\end{array}$ & $\begin{array}{l}r=- \\
0,014 \\
p= \\
0,934\end{array}$ \\
\hline \% Presença & & & & & & & & & & $\begin{array}{l}r=0,534 \\
p=0,000\end{array}$ & $\begin{array}{l}r=0,408 \\
p=0,009\end{array}$ & $\begin{array}{l}r=-0,122 \\
p=0,452\end{array}$ & $\begin{array}{l}r=-0,095 \\
p=0,558\end{array}$ & $\begin{array}{l}r= \\
0,413 \\
p= \\
0,008\end{array}$ \\
\hline $\begin{array}{l}\text { Média de } \\
\text { frequência }\end{array}$ & & & & & & & & & & & $\begin{array}{l}r=0,675 \\
p=0,009\end{array}$ & $\begin{array}{l}r=0,069 \\
p=0,673\end{array}$ & $\begin{array}{l}r=-0,070 \\
p=0,668\end{array}$ & $\begin{array}{l}r= \\
0,201 \\
p= \\
0,215\end{array}$ \\
\hline $\begin{array}{l}\text { Média de } \\
\text { Intensidade }\end{array}$ & & & & & & & & & & & & $\begin{array}{l}r=-0,038 \\
p=0,816\end{array}$ & $\begin{array}{l}r=-0,081 \\
p=0,620\end{array}$ & $\begin{array}{l}r=- \\
0,210 \\
p= \\
0,194\end{array}$ \\
\hline Competência & & & & & & & & & & & & & $\begin{array}{l}r=0,755 \\
p=0,000\end{array}$ & $\begin{array}{l}r= \\
0,177 \\
p= \\
0,273\end{array}$ \\
\hline Desempenho & & & & & & & & & & & & & & $\begin{array}{l}r= \\
0,159 \\
p= \\
0,329\end{array}$ \\
\hline Total - NBTA & & & & & & & & & & & & & & \\
\hline
\end{tabular}

